\title{
A poesia insólita do cinema científico
}

\author{
Versão Corrigida \\ (versão original disponível na Biblioteca da ECA/USP).
}

Tese apresentada à Escola de Comunicações e Artes da Universidade de São Paulo para a obtenção do título de Doutora em Meios e Processos Audiovisuais.

Área de concentração: Poéticas e Técnicas Orientador: Prof. Dr. Atílio José Avancini 

Autorizo a reprodução e divulgação total ou parcial deste trabalho, por qualquer meio convencional ou eletrônico, para fins de estudo e pesquisa, desde que citada a fonte.

Marques, Maria Luiza Dias de Almeida

A poesia insólita do cinema científico / Maria Luiza Dias

de Almeida Marques ; orientador, Atílio José Avancini. -São Paulo, 2020

251 p.: il. + dvd.

Tese (Doutorado) - Programa de Pós-Graduação em Meios e Processos Audiovisuais - Escola de Comunicações e Artes / Universidade de São Paulo.

Bibliografia

Versão corrigida

1. cinema 2. nicolau copérnico 3. cinema de animação 4. cinema científico 5. poética no cinema I. Avancini, Atílio José II. Título.

CDD 21.ed. - 791.43 


\section{FOLHA DE APROVAÇÃO}

MARQUES, Maria Luiza Dias de Almeida. A poesia insólita do cinema científico. 2020. $251 \mathrm{fls}$, Tese (Doutorado em Meios e Processos Audiovisuais) - Escola de Comunicações e Artes, Universidade de São Paulo, São Paulo, 2020.

Aprovada em:

\section{Banca Examinadora}

Prof (a). Dr.

Instituição

Julgamento

Prof (a). Dr.

Instituição

Julgamento

Prof (a). Dr.

Instituição

Julgamento

Prof (a). Dr.

Instituição

Julgamento 
Esta tese é dedicada à Maria do Carmo Santos Domite e a Letícia Scarpa de Albuquerque Maranhão 


\section{AGRADECIMENTOS}

Ao prof. dr. Atílio José Avancini, por me conduzir em cada passo na trincheira da pesquisa.

À profa. dra. Teresa Castro, pelo convite à temporada de pesquisa no Institut de la Recherche en Cinéma et Audiovisual (IRCAV), na Universidade Sorbonne Nouvelle-Paris 3, pelas sugestões de leitura e pelos encontros tão produtivos.

Ao prof. dr. Carlos Augusto Calil, por intermediar a digitalização dos filmes junto à Cinemateca Brasileira.

À FAAP, por me conceder o período de licença para a temporada de pesquisa na Universidade Sorbonne Nouvelle-Paris 3. Ao prof. Eliseu Lopes Filho, pela confiança e por intermediar burocraticamente essa licença junto à FAAP.

Ao amigo Fernando Fontanetti, pela tradução do resumo da pesquisa para o seu elegante inglês.

Ao meu amado Paulo de Tarso Domite Mendonça, companheiro de vida, que se manteve firme a meu lado de mãos dadas durante todos esses anos.

Aos meus pais, sempre. 
"O esforço da atenção é o ato essencial da vontade."

William James, 1890 


\section{RESUMO}

Esta tese consiste em um estudo sobre o cinema científico, discutindo linguagem e estética, com o propósito de buscar compreender seu lugar e seu valor na cultura audiovisual. A hipótese de pesquisa é que o cinema científico insere-se em um contexto de criação e de produção de conhecimento em que a linguagem poética e a imaginação ocupam lugar privilegiado. Investigar o terreno da ciência em filme teve como objetivo compreender as conexões entre o cinema e a ciência do ponto de vista dos procedimentos, do público e dos significados. Para tanto, foi necessário encontrar uma definição abrangente do gênero científico dentro do cinema, entendendo-o como uma linguagem híbrida, singular e transdisciplinar. Como método, adotamos: estudar a origem das imagens científicas e sua evolução desde a ilustração, a fotografia e o cinema; observar o emprego de técnicas, linguagens e modos de enunciação no cinema científico; entrevistar diretores e equipes de cinema científico. Constituem o objeto desta pesquisa os filmes de Marcello Tassara De Revolutionibus e a série de curtas-metragens Centro de massa (recuperados e digitalizados para esta pesquisa), e Nicholas Copernicus, de Ray e Charles Eames. A análise destes objetos e de outras produções em âmbito mundial subsidiou a hipótese da possibilidade da linguagem poética e criativa no cinema científico.

Palavras-chave: cinema científico; filme de pesquisa acadêmica; poética no cinema; Nicolau Copérnico; De Revolutionibus. 


\begin{abstract}
This thesis comprises a study about the scientific cinema, discussing language and aesthetics aiming to understand its status and its value in the audiovisual culture. The research hypothesis is that the scientific cinema lies within a context of creation and production of knowledge in which poetic language and imagination have a prominent place. By looking into the domain of science in cinema we targeted to understand the connections between science and cinema from the standpoint of the procedures, public and meanings (symbolization). In view of that, it was mandatory to find a broader definition of scientific genre within cinema, taking it as a hybrid, singular and transdisciplinary language. Regarding the method, it encompasses: studying the origin of scientific images and their evolvement from (since) illustration, photography and cinema; observing the use of techniques, languages and forms of enunciation in the scientific cinema; interviewing directors and groups of scientific cinema. The object of this research comprises Marcello Tassara's films De Revolutionibus and the series of short films Centro de massa (recovered and remastered for this research), and Nicholas Copernicus by Ray and Charles Eames. The analysis of these objects and other worldwide film productions supported the hypothesis of poetic and creative language in the scientific cinema.
\end{abstract}

Keywords: scientific cinema; film of academic research; cinema poetics; Nicolas Copernicus; De Revolutionibus. 


\section{RÉSUMÉ}

Cette thèse présente une étude sur le cinéma scientifique, ayant pour but de comprendre son rôle et sa valeur dans la culture audio-visuelle; elle cherche également à discuter le langage et l'esthétique. L'hypothèse de recherche soulevée repose sur le fait que le cinéma scientifique fait partie d'un contexte de création et de production de connaissances dans lequel le langage poétique et l'imagination ont une place privilégiée. Investiguer le domaine de la science véhiculée en format de film a eu comme objectif de comprendre les connexions entre le cinéma et la science du point de vue des procédures, du public visé et des sens. Pour ce faire, il nous a fallu trouver une définition large du genre scientifique dans le cinéma, en le comprenant comme un langage hybride, singulier et transdisciplinaire. Comme méthode, nous avons adopté les étapes suivantes: étudier l'origine des images scientifiques et son évolution de l'illustration, en passant par la photographie, jusqu'au cinéma; observer l'usage de techniques, langages et formes d'énonciation dans le cinéma scientifique; et interviewer des réalisateurs et des équipes de production de cinéma scientifique. L'objet d'analyse de cette recherche est composé des films de Marcello Tassara De Revolutionibus, de la série de courts-métrages Centro de Massa (récupérés et numérisés pour cette recherche) et de Nicholas Copernicus, de Ray et Charles Eames. L'analyse de ces objets et d'autres productions réalisées dans différents pays a appuyé l'hypothèse selon laquelle il y a possiblement un langage poétique et créatif dans le cinéma scientifique.

Mots-clé: cinéma scientifique; film de recherche académique; poétique du cinéma; Nicolas Copernicus; De Revolutionibus. 


\section{SUMÁRIO}

INTRODUÇÃO

Capítulo 1 - As imagens no contexto científico - sensibilização e sedução do olhar ........ 30

I.I A pintura de ilustração como ciência de compreensão visual .................................... 30

I.II Fotografia - o olho mecânico e preciso como espelho do real................................. 46



Capítulo 2 - Poéticas e práticas no cinema científico - comunicação do sensível 113

Capítulo 3 - De Revolutionibus e Nicholas Copernicus - poéticas da ordem e da desordem 130

Capítulo 4 - Evolução técnica e poética da animação científica. 160

Capítulo 5 - Tecnologia das imagens científicas e a ponte com a arte - soluções e armadilhas. 175

Considerações finais 188

Referências bibliográficas 195

ANEXO I - Transcrição da entrevista com Marcello Tassara (10/04/2017) 207

ANEXO II - Transcrição da entrevista com Maria Dora Mourão (07/11/2017) 226

ANEXO III - Transcrição da entrevista com Ella Dürst (06/11/2017). 229

ANEXO IV - Transcrição Ismail Xavier (29/09/2019) 233

APÊNDICES - Revistas históricas 238 


\section{INTRODUÇÃO}

Esta pesquisa é fruto de um antigo entusiasmo por dois temas que me acompanham ao longo da vida escolar: as ciências e o cinema. Quando digo entusiasmo refiro-me a um gostar pleno de interesse e de questionamento livre, com perguntas e respostas que se apresentam erraticamente sem compromisso com uma correção existente a priori. A exemplo das digressões de Rubem Alves em $O$ que é científico? (2007), o que moveu inicialmente a pesquisa foi a curiosidade descompromissada de alguém que quer saber o que tem do outro lado do muro, ou entender como funcionam as coisas pelo simples prazer de conhecer.

Outro motor da pesquisa foi uma noção, ainda que vaga, de que o sentimento experimentado ante a beleza de certos fenômenos da natureza pode ser da mesma ordem que aquele experimentado ao sermos expostos a uma obra de arte, um filme, uma música. A carga afetiva disparada por tais vivências prepara o terreno para que se veja o mundo de outra forma, possibilitando a transformação do sujeito que vê/ouve/experimenta pela apreensão. Irreversivelmente tocado, de posse de percepções novas e com um certo trabalho intelectual, o sujeito constrói conhecimento. Essas ideias não são novas e existe todo um arcabouço de estudos em pedagogia que trabalha a questão da arte em educação com diferentes perspectivas.

Neste estudo, aos poucos o pensamento original delineou-se mais formalmente. Vale salientar que alguns encontros vividos no início desta pesquisa, os quais foram determinantes para abrir meus olhos e colocar na corrente certa um barco que navegava meio à deriva, não teriam acontecido sem o sopro da coincidência.

Os fenômenos naturais vistos pelo cinema apresentam aspectos sui generis que ultrapassam os limites da simples contemplação. Quem os testemunha não escapa da incumbência de escolher um ponto de vista, e essa escolha subjetiva resulta da combinação do objetivo científico com o senso estético. Com tomadas espetaculares, o cinema científico oferece-nos experimentar algo à beira do inacreditável, do inexplicável, sempre revelador, no sentido de que a realidade tem algo escondido. $\mathrm{O}$ título "A poesia insólita do cinema científico" refere-se portanto ao aspecto poético que emana das imagens e à qualidade singular dessa experiência. Constitui também um jogo de palavras semelhante a Discreto charme da burguesia (1972), mas a analogia refere- 
se também ao fato de o surrealista Luis Buñuel ter utilizado trechos de um filme científico na introdução de L'Âge d'or (1930), como será visto no Capítulo II.

No período em que eu redigia este projeto de pesquisa, fui conversar com o professor Tassara, físico, animador e professor de animação, para aquecer as ideias, e ele comentou a respeito de sua produção de filmes científicos e tecnológicos, ajudandome a modelar o objeto de pesquisa. Alguns dias depois, fui convidada para assistir a um colóquio sobre práticas no ensino de ciências na Escola Politécnica da USP, onde discutia-se a necessidade urgente de engajar mais estudantes para a carreira científica. Neste evento, conheci o prof. Mikyia Muramatsu, do Instituto de Física da USP (IF), e ele contou-me que, nos anos 1970, fizera filmes com animações científicas em colaboração com o pessoal da ECA/USP, o prof. Marcello Tassara e o então estudante de cinema Carlos Augusto Calil. Então, uma descarga extra de eletricidade invadiu meus neurônios, e tudo que eu precisava era um bloquinho de notas para anotar as ideias que começavam a brotar. Evidentemente não deixei o prof. Mikyia ir embora antes de deixar amarrado um encontro para dar continuidade àquela conversa. A rota das coincidências não parou por aí.

No dia do encontro, o prof. Mikyia contou-me de suas pesquisas, de seu trabalho de extensão em que realiza feiras de ciências, e entregou-me sua dissertação de mestrado de 1974, cópia única (ainda não digitalizada), bem como algumas latas de negativo do que sobrou daqueles filmes dos anos 1970. O resgate e a análise deste material constituem, pois, uma parte desta pesquisa.

Com material valioso em mãos, restava agora descobrir o conteúdo dos negativos em 35 milímetros. E como os ventos sopraram a favor, na mesma tarde em que peguei os negativos fui à ECA para descobrir o que poderia ser feito com eles. Quis o destino que lá eu encontrasse o próprio professor Carlos Augusto Calil, no corredor, de saída. Contei-lhe o que tinha em mãos e ele se interessou imediatamente. Recolheu as latas para avaliar a viabilidade da digitalização. Como produtor, fotógrafo e montador desse material, ele mesmo o conduziu à Cinemateca Brasileira para que fosse digitalizado. Quatro meses se passaram e o DVD com os filmes estavam em minhas mãos. Uma ajuda verdadeiramente preciosa.

Esse material inédito parte de um conjunto maior de filmes, que não conseguimos encontrar. A maior parte estava em processo de decomposição e logo mais se transformaria em vinagre. Assistir a esses filmes era o que faltava para definir 
objetivamente o tema que eu queria desenvolver: o cruzamento das linguagens científica e cinematográfica.

A surpresa revelada nos filmes da dupla Mikyia-Tassara valeu cada dia de espera pela digitalização, que passou por um processo burocrático na Cinemateca. Os quatro filmes sobreviventes são a expressão incontestável de que o cinema é o veículo de transmissão das ciências por excelência. Filmes curtos, cerca de dois minutos, mostram experimentos de física registrados em uma decupagem elegante, cuidada e limpa, até minimalista. As pausas para inserção de texto propõem um diálogo com o espectador evidenciando para onde deve ir o foco da atenção, sem subestimá-lo.

A partir deste material pesquisei toda filmografia do diretor Marcello Tassara, da qual extraí o filme De Revolutionibus, cuja análise constitui o centro desta pesquisa por contemplar exemplarmente aquilo que pretendo demonstrar.

Em minha prática docente na Fundação Armando Álvares Penteado (FAAP), desde 2018, onde leciono a disciplina "Animação em stop-motion", deparo-me regularmente com a problemática de trazer a atenção do estudante para a sala, onde a rotina de trabalho equilibra-se entre a teoria e a prática. A animação é uma arte especialmente artesanal, mesmo quando é feita em larga escala ou com uso de computadores. O binômio observação-realização é acionado de maneira reflexiva e pragmática simultaneamente. Por mais livre e experimental que seja, um filme de animação passa necessariamente por um planejamento, de maneira que o início das práticas costumam ser uma reflexão em torno do que é o movimento, como o percebemos, como "imitar" o tempo e subdividir o espaço. Muitos alunos relutam em relembrar princípios da física cinemática, mas a matéria-prima de nosso trabalho são as teorias de Newton - propositalmente exageradas na animação.

Iniciei a trajetória como pesquisadora dezesseis anos após o término da graduação em Cinema pela Escola de Comunicações e Artes da Universidade de São Paulo (ECA-USP). Neste hiato, especializei-me na técnica de animação quadro a quadro, o stop-motion, e trabalhei em várias produtoras de publicidade e em curtasmetragens. Trabalhei também com mídia impressa fazendo ilustrações e passatempos, com edição de vídeo, interface de jogos interativos e finalmente com a docência. $O$ curso de cinema abre uma enorme gama de possibilidades para quem trabalha com a 
área prática e técnica. Quando comecei a dar aulas no curso superior da Faculdade Anhembi-Morumbi, de 2009 a 2012, senti a necessidade de aprofundar o conhecimento com bases mais conceituais, e comecei a refletir sobre um tema de pesquisa com o qual me identificasse. Assim, orientada pelo prof. Eduardo dos Santos Mendes, pesquisei no mestrado (PPGMPA-ECA-USP) a transição do modelo analógico de produção de animação para digital, algo que presenciei nos anos 1990 nas produtoras por onde passei.

O desejo de pesquisar o cinema científico no doutorado parte de uma reflexão inicial de que os fenômenos observáveis na natureza incitam a curiosidade humana pela necessidade de sobrevivência, mas passam também pela via da afetividade e da fruição; tais fenômenos roubam do sujeito o que chamamos de equilíbrio inicial - uma fase de repouso intelectual - ao qual ele só retorna graças ao esforço consciente de seu sistema cognitivo, em processo que vai resultar na compreensão desses fenômenos.

A fotogenia de certos experimentos registrados em filme (vídeo ou película), as evidências que só puderam ser criadas pela captura de imagens e todas as questões que envolvem o terreno do fazer-pensar em ciências e em cinema serão aqui estudados pela história das imagens nas ciências, passando por ilustração, fotografia e pela análise de material resgatado. Este processo permitiu compreender como a estética e a criação são peças-chave na abordagem cinematográfica da ciência e na produção de conhecimento.

Durante a pesquisa, houve oportunidades de expor este tema para pessoas das mais variadas formações, o que contribuiu não só para afinar a abordagem, como também para consolidar em mim mesma sobre o que afinal estaria refletindo. Durante a Socine de 2018, expus um artigo no qual salientei os procedimentos de montagem em alguns filmes científicos, os quais trago nos capítulos II e III. O debate que se seguiu revelou o interesse inesperado do público pelo tema, o que foi curioso e gratificante como retorno. Também fiz uma apresentação para o grupo de pesquisa Zootropo, voltado para o cinema de animação, do qual faço parte, recebendo inúmeras contribuições de meus colegas.

Fica mais fácil iniciar a caminhada da pesquisa trazendo uma primeira imagem como exemplo do universo que vamos focalizar. As fotografias da Figura 1 foram extraídas do vídeo realizado pelo oceanógrafo Bruno Velluttini, no Centro de Biologia Marinha da USP, em 2005. 

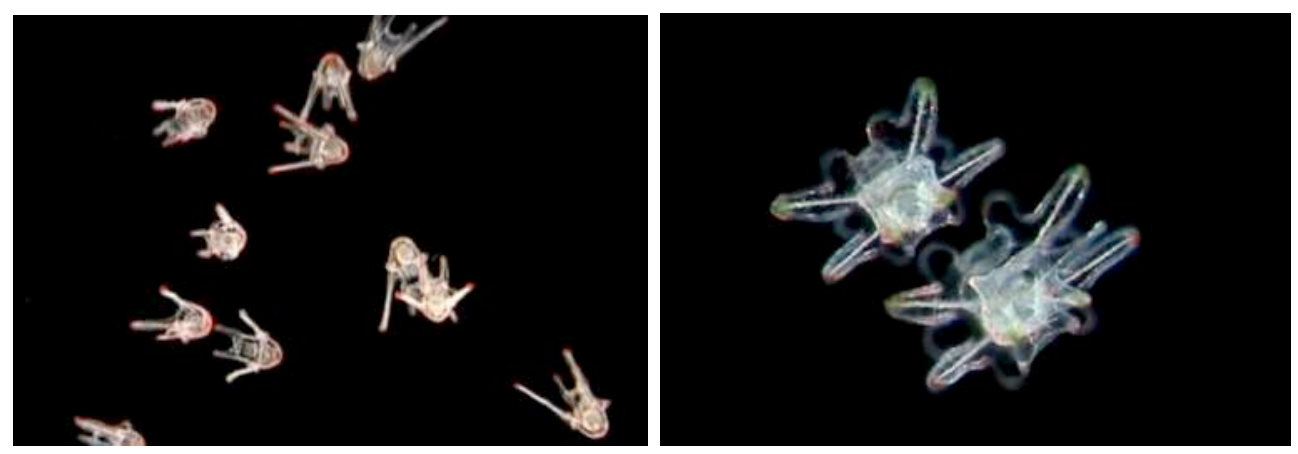

Figura 1: Imagens do filme Vida de bolacha (2008), de Bruno Velluttini, do Instituto de Oceanografia da USP.

O que são essas formas que vagam no breu? Estão à deriva, ou seu movimento obedece alguma lógica? De que são feitas? Qual seu tamanho real? Onde vivem? Como foi possível flagrá-las? Questões jorram em cascata, um processo ambivalente em que a curiosidade convive com o prazer da apreciação, e que alimenta as próximas descobertas. Os procedimentos de uma pesquisa como esta de Velluttini são criados a partir de observações e da elaboração de uma hipótese fundada em conhecimentos prévios, com o objetivo de desnudar um determinado processo. O método para o acompanhamento temporal desse experimento é o que permitirá extrair conclusões e assim compreender o fenômeno observado. Forma-se, portanto, uma cadeia de construção de conhecimento em que a imagem em movimento ocupa uma posição central como ferramenta de extensão da capacidade humana de observação.

É essa a tônica que pretendo evocar ao buscar fontes que permitam entender as componentes de um cinema científico amplo em todos os aspectos, desde seus objetivos, seus usos, seu público e suas perspectivas. Interessa-nos o cruzamento interdisciplinar pelo olhar acadêmico, artístico e técnico, em um cinema que se ocupa da vida e de tudo o que a cerca. Parto, portanto, dos objetos-imagens-em-movimento em direção às possíveis significações, considerando aspectos da teoria do cinema e da forma fílmica.

Mesmo o ambiente dito frio de um laboratório, como diz Bruno Latour (2000, p. 98), está longe de ser frio (isento de emoção). Antes, ele é um ambiente híbrido e inclui instrumentos, textos, imagens. Um experimento é repetido dezenas de vezes até que se comprove ou se refute uma hipótese e, quando é bem-sucedido, impulsiona a pesquisa, leva o cientista obcecado a um estado emocional de êxtase. No universo dos laboratórios, não é raro ouvir-se a expressão "conseguimos belas imagens”, após uma 
captação de imagem exitosa que revela/demonstra/ilustra uma hipótese posta à prova. Foi o que disse o astrônomo Pierre-Jules César Janssen, o primeiro astrônomo a obter uma sequência de fotografias em intervalos mais ou menos constantes em 1874, no Japão, durante a passagem de Vênus pela frente do Sol. Ao invocar a "beleza", Janssen expõe o duplo interesse de seu investimento: no êxito da captura das imagens ao ponto de se fazerem identificáveis; na qualidade da informação que elas lhe permitem auferir.

Anos mais tarde, quando outro grupo de cientistas utilizou seu equipamento, Janssen declarou: "eles obtiveram uma linda série de imagens". A noção de beleza, neste caso, é a clássica, que busca o equilíbrio e a harmonia. Essa noção de beleza na ciência aponta para uma estética da nitidez como qualidade a ser perseguida para algo que sirva de evidência válida de um fenômeno estudado. A beleza pode ser entendida como o atributo que coloca ordem no caos e traz compreensão.

O papel da sensibilidade estética é a conexão entre ciência e arte que buscamos explorar, ao observar a evolução técnica, com uma certa tradição na representação figurativa e com a imaginação como especificidade humana. Arte/técnica e ciência/técnica caminham juntas desde o tempo em que a humanidade demonstrou o desejo de se expressar pelas mais variadas necessidades. A partir desse anseio natural, as formas de registro evoluíram e servem de indícios para o entendimento dos processos de aquisição de conhecimento. Como forma de transmissão de saberes, os registros repercutem e se transmutam em novas formas de compreensão da realidade, estas também variáveis, conforme a visão de mundo da época.

Além da sensibilidade estética, procuramos entender o valor da imaginação e da intuição como importantes engrenagens na busca do conhecimento. A esse respeito, encontramos dois depoimentos que se complementam, o do prof. dr. Ismail Xavier (formado em engenharia pela Escola Politécnica da USP) e o de Peter Medawar (Nobel de medicina em 1960).

[...] sempre tem uma tônica importante que os meus colegas matemáticos ou físicos reiteram que é o fato de que, em ciência, o que é fundamental é a intuição. Sem uma intuição, sem uma direção assumida numa ideia importante, num "poder imaginar hipóteses", é uma coisa que não anda, porque o aspecto demonstrativo vem depois [...] vai demandar matemática, geometria analítica [...], mas essa parte de cálculo é uma etapa do processo; sem o movimento inicial da ideia e da convicção, a coisa não anda. É o motor. (XAVIER, ANEXO IV) ${ }^{1}$

\footnotetext{
${ }^{1}$ A íntegra das entrevistas realizadas para esta pesquisa está nos anexos.
} 
A parte mais importante do trabalho intelectual não é necessariamente consciente, [...] as descobertas e as ideias dependem de intuições que surgem depois de mergulhos de trabalho mental. Esses brilhos da imaginação vêm de uma incubação quando o pesquisador não está trabalhando. (MEDAWAR apud DASTON; GALISON, 2010, p. 311)

Com um intervalo de mais de quarenta anos, esses dois acadêmicos demonstram concordar na compreensão de como se dão os processos mentais envolvidos na pesquisa científica.

Trago portanto, como eixo da pesquisa, a interrogação: é possível haver linguagem poética na narrativa cinematográfica de conteúdo científico? Como ela se manifesta? Quais são os limites para uma representação poética no terreno da ciência sem que se abandone a premissa essencial? Estas perguntas atravessam a pesquisa em busca do que há nas entrelinhas da linguagem científica, em busca do jogo com o implícito.

Ao escolher a relação entre arte cinematográfica e ciência, pensamos também na contaminação colaborativa entre essas duas instituições, em todas as instâncias, dado que o saber fazer cinematográfico deve se alinhar ao propósito de determinado experimento/conceito científico. O denominador comum entre as práticas artística e científica reside no método, o eixo que determinará o sucesso e a validade contida no assunto estudado/retratado. Portanto, o tom da pesquisa vagueia entre a elasticidade e a rigidez, ora contemplativo, ora crítico, evitando sempre o conformismo no tratamento das informações.

Entendendo o campo das imagens em movimento como o lugar da simbiose entre técnica e a arte, recorremos à reflexão de Gene Youngblood em seu Expanded Cinema, para quem ciência e arte, em um amplo sentido, são a mesma coisa, na medida em que são práticas humanas que correspondem a visões do mesmo mundo: “[...] ordenar os fatos de uma experiência é revelar a relação entre o homem e o universo que o circunda com todo o potencial escondido" (YOUNGBLOOD, 1970, p. 70).

As especulações de Youngblood podem parecer datadas ou muito relacionadas à ebulição dos anos 1960, em que uma nova consciência brotava de experiências em todos os campos do conhecimento humano. De reivindicações sociais, ao uso de alucinógenos, passando pela Guerra Fria, Youngblood, em tom profético, encara a mídia do futuro como uma verdadeira teia de informação não linear e saturada, muito mais a serviço da cegueira do que da revelação. Sua colaboração nesta pesquisa envolve as considerações acerca de sensibilidade, do conhecimento e da arte, e se divide em 
duas frentes. Na primeira, as relações do audiovisual com a ciência e o conhecimento. Na segunda, a reflexão relacionada com as fronteiras do cinema e com o seu devir. Em ambos os casos, Youngblood coloca o ser humano no centro da discussão, chamando atenção para a mudança de atitude constante frente às novas tecnologias e ao seu impacto no comportamento da sociedade.

Seria o científico atrelado ao mundo exterior, concreto, o reino da objetividade; enquanto que o artístico voltado ao mundo interior, às idiossincrasias individuais, ao campo da subjetividade? Há tempos essa dicotomia não aquece mais as discussões, simplesmente porque não corresponde mais aos problemas das pesquisas contemporâneas em audiovisual. Nem a disciplina mais dura dos cálculos está imune a uma pontada de intuição. O que nos parece estar em jogo no fazer científico é a ética, o compromisso com a verdade encarnado pela postura do pesquisador. Não é a pretensão deste trabalho aprofundar a questão filosófica em torno dos termos verdade/realidade, o que não nos isenta de adotar uma visão crítica a respeito das manipulações incontornáveis do cinema como ferramenta.

Interessa-nos na relação cinema-ciência compreender como se dão as relações entre observação e criação. Seja na captura do material, seja na sua manipulação/montagem, sempre haverá na atividade de organização desses conteúdos um método e um objetivo. O esforço do pesquisador/cineasta no desenvolvimento do método serve para assegurar em alguma medida o valor científico contido no experimento documentado, ou no conceito/teoria que se quer ensinar. Como defende Virgilio Tosi, o cinema científico é uma nova linguagem.

Além deste lugar preestabelecido "de quem vê", exercício da tradução de conteúdos, as imagens carregam uma parcela de inventividade - o olhar de alguém que escolhe o que retratar, por qual ponto de vista, quais elementos merecerão destaque. É preciso se fazer entender, esta é a meta primeira.

O resgate dos filmes da Física em consórcio com a ECA, a filmografia de Tassara, suas qualidades estéticas, e o contexto em que foi produzida são o germe da questão. $\mathrm{O}$ que caracteriza essas obras e quais atributos elas trazem em comum com a tradição fílmica (científica ou não) e o que apresentam como elementos de ruptura nessa tradição são outras perguntas que tentaremos responder aqui.

Jacques Aumont (2009, p. 100) estabelece uma linha que liga o cinema científico ao cinema dito narrativo ficcional: "o que caracteriza os filmes de ficção é a representação de algo imaginário, uma história”. Neles, a linguagem está a serviço de, a 
um só tempo, narrar e envolver o espectador em um ambiente irreal. O filme científico, ainda que inscrito no estatuto do real (concreto, palpável), obedece à lei do filme de ficção, da representação da realidade de determinado fenômeno com ênfase na sua peculiaridade, naquilo que ele tem de espetacular. Podemos, então, inferir que o interesse despertado por tais imagens reside na apresentação dos "aspectos desconhecidos da realidade que dependem mais do imaginário que do real. [...] o espectador encontra-se mergulhado no fabuloso" (AUMONT, 2009, p. 101).

Alguns anos após Janssen, Etienne-Jules Marey, Albert Londe, entre outros, também precisaram desenvolver artefatos de captação de imagens em sequência com o propósito de criar material de pesquisa e assim dar corpo ao que pretendiam defender em suas teses. Marey, desenvolveu instrumentos para suas pesquisas em sequência de imagens fotográficas, mas também produziu imagens geradas a partir de outros dispositivos, como o esfimógrafo, usado para medir a pressão sanguínea. $\mathrm{O}$ equipamento de Marey era sensível à pulsação cardíaca e era capaz de “desenhar" com uma agulha, tracionada por um mecanismo de relógio, sobre uma folha de papel coberta com pó de grafite. O padrão do grafismo produzido pelo esfimógrafo de Marey permanece até os dias de hoje em equipamentos de monitoramento cardíaco. Aquilo que é invisível ao olho nu ganha uma forma compreensível e ponderável graças à transcrição de um evento real para um sistema em que a analogia pela imagem pode ser interpretada. Trata-se do método gráfico, que já existia desde o século XVIII, e que Marey sistematizou e popularizou (com o nome de réprésentation graphique des phenomènes).

Com trabalho praticamente paralelo ao de Marey, o fotógrafo Eadweard Muybridge serviu igualmente a propósitos científicos, tanto pelo desenvolvimento do mecanismo que acionava as câmeras em sequência, como pelas imagens obtidas. Apesar de não ser cientista de laboratório, aplicou seu conhecimento de fotografia a diversos campos das ciências e também das artes.

Janssen, Marey e Muybridge interessavam-se na decomposição do movimento, na descoberta de movimentos muito fugazes para nossa percepção natural. É inegável sua contribuição para o desenvolvimento do cinema, ainda que não se propusessem a projetar as sequências obtidas, mas sim analisá-las. No campo das ciências, foram fonte 
de estudo para diversos pesquisadores que produziram seus equipamentos, cada qual com adaptações para as áreas de estudo. A compreensão dos processos de captação de imagem e de movimento possibilitou inúmeros desdobramentos no campo da produção de imagens não apenas voltadas para a ciência, mas para o entretenimento e para as artes, como por exemplo a holografia, a robótica e o pelo motion capture. O cinema de ficção científica, ao trabalhar realidades impossíveis (pelo menos em princípio, com os recursos tecnológicos atuais), dialoga frequentemente com o cinema científico, de quem empresta não apenas processos de criação de imagem, como também toda uma simbologia e uma retórica visual relacionadas ao imaginário entendido como científico.

O pesquisador do cinema científico Virgilio Tosi (cujo levantamento é possivelmente o mais completo e contextualizado) reivindica uma história do cinema forjada nos laboratórios em função das necessidades da sociedade que se modernizava no século XIX. Ele não apenas historiografa como também fornece uma bibliografia de época que auxilia na compreensão de como a fotografia passou de uma técnica para uma disciplina; até porque a fotografia não foi aceita pela academia de imediato como ferramenta de precisão para pesquisa. Para ele, o cinema-ciência existe antes do cinema de entretenimento, pois o dispositivo só pôde se desenvolver e se estabilizar devido aos esforços de pesquisadores dos fenômenos da natureza. Temos, de um lado, o estudo fisiológico da retina, os dispositivos fotográficos e a química para a fixação da imagem com o objetivo de tirar o véu da natureza, penetrar-lhe os mistérios e dominá-la. Ampliar a percepção e testar hipóteses eram objetivos de pesquisa no campo do movimento, o que estimulou, portanto, o desenvolvimento do cinema.

Por outro lado, há quem defenda que a invenção do cinema não se deva exclusivamente à ciencia. André Bazin (1991, p. 24), por exemplo, afirma que o cinema já existia na cabeça de muita gente que persistiu nas tentativas de materializá-lo como uma ideia fixa.

Os fanáticos, os maníacos, os pioneiros desinteressados, capazes, como Bernard Palissy, de botar fogo em sua casa por alguns segundos de imagens tremeluzentes, não são cientistas ou industriais, mas indivíduos possuídos pela imaginação. Para ele, "o cinema não deve quase nada ao espírito científico, [...] com exceção de Marey, mas é significativo que Marey só se interessasse pela análise do movimento, não pela sua recomposição" (BAZIN, 1991, p. 27). 
Arlindo Machado (1997, p. 6), por sua vez, enfatiza a contribuição de um elemento não racional, mais ligado à tradição humana do narrar, do que unicamente à exploração objetiva da natureza. Experimentos menos ortodoxos (até perigosos) feitos por pessoas comuns refletiam "uma acumulação subterrânea, uma vontade milenar de intervir no imaginário". O encantamento genuíno pelo movimento da imagem no tempo expressava a "emergência do imaginário e o que ele tem de gratuito, excêntrico e desejante, tudo isso, enfim, que constitui o motor mesmo do movimento invisível que conduz ao cinema" (MACHADO, 1997, p. 6).

Parte dessa argumentação ganha reforço quando observamos a obra de Emile Reynaud, o praxinoscópio, ou teatro óptico, entendido como a primeira forma de “cinema", já que se trata de uma projeção de imagens em movimento. O mecanismo complexo de Reynaud, que consistia de dupla exposição - uma do cenário fixo, outra, dos personagens animados - foi concebido para apresentar desenhos. Mais tarde considerou-se substituir as lâminas desenhadas por lâminas com imagens fotográficas, como forma de tornar a projeção da figura mais estável.

Vale lembrar a colaboração entre Marey e os Lumière, em que o pai dos irmãos Lumière fornecia material sensível a Marey, enquanto este recebia gentilmente os irmãos em sua oficina, mostrando-lhes detalhes de seus inventos (nenhum foi patenteado). O cinema desenvolvido pelos irmãos identifica-se com o registro para espetáculo/entretenimento, enquanto Marey segue com seu trabalho analítico, inspirando cientistas pela Europa e pela América.

$\mathrm{O}$ interesse pela captação mecânica da imagem é uma das faces do ambiente do século XIX, e o estudo do movimento, de máquinas, de formas de impressão corresponde à expansão de uma visão de mundo em busca da eficácia dos mecanismos de produção. Uma das ideias que está por trás é a eliminação dos erros humanos que a máquina fria e cega tende a evitar. Dar visibilidade ao que os olhos não podem ver naturalmente implica criação e representação, já que 0 arbitrário e a manipulação/interpretação são potenciais fontes de engano. O compromisso com a ética resulta em credibilidade.

Neste universo dos filmes de pesquisa, divulgação científica ou pedagógica, encontramos no filme De Revolutionibus, dirigido em 1973 por Tassara, a síntese do 
diálogo entre o cinema e a ciência. Realizado em comemoração aos 500 anos do nascimento do astrônomo e matemático polonês Nicolau Copérnico (1473-1543), o título faz menção à obra De Revolutionibus Orbium Coelestium [Das revoluções das órbitas celestes], em que Copérnico descreve pormenorizadamente os cálculos que o levaram a concluir que o Sol - e não a Terra - está no centro do universo.

Também por ocasião dos 500 anos de Copérnico, foi realizado o filme Nicholas Copernicus (1973) pelo casal norte-americano Ray e Charles Eames. Vemos neste curta-metragem um contraponto exato a De Revolutionibus, posto que, filmado na mesma época e pelo mesmo motivo, o filme dos Eames explora o universo de Copérnico em outra proposta. Nicholas Copernicus contextualiza vida e pensamento pela chave da contemplação e da elegância. Contraponto, também, dados os diferentes orçamentos e regimes de produção. Rico em imagens coletadas no local onde viveu e trabalhou Copérnico, o filme mostra seus objetos pessoais, seus manuscritos e cálculos, e uma impressão original da obra. Com delicadeza e sobriedade, o filme oferece a atmosfera de um tempo, com uma trilha musical especialmente composta.

O filme dos Eames teve a pesquisa patrocinada pela IBM, o que lhes permitiu viajar para a Europa e estudar toda iconografia que cerca a figura de Copérnico, como seus livros e gravuras, objetos e instrumentos científicos de época, além de documentos. Há muito mais diversidade nas imagens coletadas in loco para o Copernicus dos Eames, já que o filme fez parte de um evento muito maior em celebração aos 500 anos de nascimento do astrônomo. A beleza e a plasticidade são marca registrada no estilo dos filmes Eames, e neste curta, em especial, a composição de imagens estáticas, planos de detalhe em macro, movimentos sutis e trilha especialmente composta para ele evidenciam a busca pela precisão.

É impossível não comparar os dois filmes, já que partem do mesmo ponto e cumprem demandas semelhantes. $\mathrm{Na}$ análise que proponho, aponto para semelhanças e diferenças formais na relação que estabelecem com o objeto retratado, e nas estratégias narrativas que encampam. Ou seja, as diferenças no emprego da linguagem do cinema na composição de cada retrato do cientista. Proponho uma observação atenta que conduza à reflexão a respeito do modo como cada filme interpela o espectador.

Defendemos nesta tese que o filme realizado no Brasil (ECA - USP) articula de forma radicalmente mais complexa o conjunto das imagens coletadas, apontando não apenas para a grandeza da contribuição de Copérnico, mas lançando ao público o 
convite para olhar nosso tempo e identificar o que ainda pode ser descoberto, desafiando os dogmatismos e as crenças prontas.

A hipótese, portanto, é comprovar que se pode extrair dessas imagens, tão enraizadas na realidade palpável, um conteúdo de potencial poético que transcenda à informação e reserve à imaginação um lugar privilegiado no conhecimento: "a imagem poética clareia a consciência" (BACHELARD, 1960, p. 3). E também demonstrar que esta categoria de filmes que explora a realidade concreta é fonte inesgotável de plasticidade e de surpresa, trabalhando imagens que flertam com a abstração e com novas possibilidades narrativas. Em outras palavras, o audiovisual de conteúdo científico imbuído de pensamento poético pode apresentar uma liberdade de expressão que coexista com o método científico.

Foi natural, ao encontrar De Revolutionibus, que este tenha se destacado como centro da observação. O filme exercita com profunda liberdade estética a mescla de imagens animadas em stop-motion, trucagens quadro a quadro e cenas captadas a $24 \mathrm{fps}$ para tecer um painel e descrever a cosmovisão e a teoria de Copérnico. Não se deixa de lado o fato de que o uso inventivo da montagem e da animação resultou, em grande medida, como se atestou nas entrevistas, da escassez de tempo e de recursos. Tal manejo das imagens oferece ao espectador a experiência de transitar entre duas visões de mundo, como nos explicou o diretor na ocasião em que revimos juntos o filme:

\footnotetext{
A ideia desse filme foi muito além do que simplesmente mostrar o movimento dos planetas etc. A ideia era ilustrar como a ciência evolui, era uma forma de dizer isso. Como a ciência evolui, ao contrário do processo de descascar um abacaxi, ou uma cebola, você vai juntando coisas, você não modifica as coisas. [...] A mecânica de Newton funciona de certa maneira. Quando veio a teoria da relatividade, aquelas ideias do Newton tiveram que ser revistas. (TASSARA, 2017, ANEXO I)
}

De Revolutionibus faz parte de um conjunto de filmes realizados por Marcello Tassara em equipe composta por técnicos e estudantes da ECA, alguns deles egressos do Instituto de Física e da Poli, ou seja, equipe com conhecimento de procedimentos metodológicos científicos e com domínio em técnicas cinematográficas. Na produção de um filme científico, a capacitação da equipe técnica extrapola o conhecimento cinematográfico, sendo mais que desejável o conhecimento do assunto retratado. Para a realização de De Revolutionibus foi providencial haver na equipe gente de cinema com experiência em ciências, como é o caso do roteirista prof. Ismail Xavier, formado em engenharia mecânica 
Filmes de ensino ou pesquisa não foram mais realizados na ECA-USP, até que o prof. Mario Guidi solicitasse um auxílio técnico para sua pesquisa no Instituto de Psicologia da USP. Guidi, filósofo de formação, pesquisador e professor na psicologia e depois na ECA, desenvolveu uma pesquisa sobre o ciclo de reprodução da formiga saúva, para a qual usou o cinema como instrumento de pesquisa. Guidi também construiu a primeira caixa de Skinner no Brasil, nos anos 1960, para observação de comportamento animal. Sua tese de doutorado, defendida no final dos anos 1970, gerou polêmica ao incluir um filme como material de pesquisa, já que era suposto que uma tese contivesse apenas o texto escrito e imagens, mas não material fílmico. É notável que, em 1859, Marey já tivesse publicado sua tese sobre a circulação do sangue, que se fundamentava nas pesquisas com método gráfico obtido com seus equipamentos e com uso de imagens em sequência.

A escassa bibliografia exclusiva sobre o tema no Brasil não foi de todo negativa, e acabou por corroborar a percepção de que se trata de um campo em que ainda há muito o que explorar. Há, de um lado, a dificuldade em preencher lacunas de informação, e de outro, o desafio de garimpar e costurar as ideias de maneira orgânica e consistente, o que, aos poucos, torna-se uma tarefa gratificante. Nesse sentido, foi um presente para a pesquisa o convite da profa. dra. Teresa Castro para passar três meses no Institut de Recherche sur le Cinéma et l'Audiovisuel (IRCAV), laboratório da Sorbonne Nouvelle - Paris 3. Logo no primeiro dia de biblioteca, encontrei uma publicação específica sobre o cinema científico de cuja bibliografia extraí outras tantas obras essenciais para a redação final desta tese. As visitas à Biblioteca Nacional da França e à Cinemateca Francesa também foram valiosas na coleta de material/fonte primária a respeito do tema, como artigos de revistas e microfilmes com publicações das primeiras décadas do século XX.

Seguem alguns autores que proveram a base sobre a qual a pesquisa se erigiu, seja por meio de informações, conceitos ou linhas filosóficas que nos ajudaram a pensar as possíveis conexões entre o universo da ciência e o das artes cinematográficas: Arlindo Machado, Virgilio Tosi, Gaston Bachelard, Erwin Panofski.

Machado comenta sua própria experiência na realização de um filme científico e enumera algumas produções brasileiras e estrangeiras que se encaixam no gênero, e sua 
obra contribui com a reflexão a respeito das diferenças entre o filme científico e o didático. Tosi apresenta-nos um panorama detalhado da evolução técnica da fotografia e do cinema voltados para investigações científicas. Bachelard é o autor que nos provê de uma visão filosófica em torno da evolução do pensamento científico e do papel da imagem neste percurso. Panofski apresenta um método para análise de obras de arte em seu livro O significado nas artes visuais (1976), que auxiliou a descortinar os filmes que discutimos.

Fora estes, outros autores foram essenciais para encaminhar a reflexão a que nos propomos, como Rudolph Arnheim, Roland Barthes e Jacques Aumont, entre outros.

\section{Das entrevistas}

Considerando que nosso objeto de estudo central é uma produção resgatada, aproveitamos que vários colaboradores dos filmes estudados ainda estão na ativa para realizar entrevistas com o intuito de estabelecer uma ponte entre o modo de produção e a forma de linguagem. Um dos problemas que enfrentamos é o fato de não termos encontrado nem o roteiro dos filmes feitos com o IF, nem o roteiro do De Revolutionibus, o que nos impediu de estabelecer algumas conexões entre o raciocínio do diretor e da montadora e como foram pensadas as imagens em relação às músicas.

Marcello Tassara, Mikyia Muramatsu, Maria Dora Mourão, Ismail Xavier e Ella Durst dispuseram-se a colaborar com a pesquisa trazendo suas impressões e lembrando seu método de trabalho. Outras entrevistas pareceram pertinentes, por exemplo com a da profa. Marília Franco, que montou o filme para a tese de doutorado do prof. Mario Guidi no Instituto de Psicologia da USP. As entrevistas foram estruturadas com questões abertas, em que os entrevistados assistiram ao filme junto com a entrevistadora e relembraram momentos da produção. Algumas das questões apresentadas foram:

O que se lembra deste trabalho?

Como surgiu determinada escolha temática/técnica?

Como vê esta obra hoje? Ainda hoje faz sentido?

Você achou instigante trabalhar no filme? Conte-nos sua participação.

Você acha que, além da informação científica objetiva, o filme também lida com a dimensão da imaginação?

O percurso da pesquisa está sumarizado de forma a seguir uma cronologia a partir do final da Idade Média até a conquista do cinema. Em seguida, trato das 
particularidades do cinema científico no século XX até os anos de 1960. Ao chegar no capítulo III, focado na produção brasileira dos anos 1970, aprofundo na observação do nosso objeto da pesquisa. A animação e os desdobramentos do cinema científico são comentadas nos capítulos finais. Assim, temos nosso em sumário:

\section{Capítulo I - As imagem no contexto científico - sensibilização/sedução do olhar}

No Capítulo I exponho um painel cronológico que vai do final da Idade Média até o início do século XX, procurando entender em que medida a visão de mundo é expressa pelas imagens e técnicas de observação vistas nos documentos relacionados às ciências, notadamente a anatomia, a fisiologia, a astronomia e a física. Entre tantas formas de estruturar este capítulo, a que resultou mais pertinente foi:

\section{I.I A pintura de ilustração como ciência de compreensão visual}

I.II Fotografia - o olho mecânico e preciso como espelho do real I.III Filme - Especificidades e contaminações

\section{Capítulo II - Poéticas e práticas no cinema científico - a comunicação do sensível}

O foco neste capítulo foi reconhecer obras do cinema científico que não se restringem a uma linguagem científica "dura", desumanizada. Destacamos alguns filmes que tratam a ciência de forma rigorosa, mas usufruem da linguagem cinematográfica como uma janela para outros campos com os quais pode se relacionar de forma poética.

\section{Capítulo III - De Revolutionibus e Nicholas Copernicus - poéticas da ordem e da desordem}

Aqui está o coração da pesquisa, o motivo pelo qual todo trabalho se iniciou, com a análise comparativa dos filmes De Revolutionibus e Nicholas Copernicus, bem como dos filmes do IF e da ECA resgatados e digitalizados. 


\section{Capítulo IV - Poética da animação científica}

Neste capítulo, observamos diferentes modos como a ciência se serve das técnicas da animação para materializar conceitos de difícil apreensão, bem como o uso criativo e irreverente com o qual alguns cineastas tratam das ciências.

\section{Capítulo V - Tecnologia das imagens científicas}

Aqui ocorre uma espécie de sublimação da linguagem matemática por meio dos recursos computacionais: a tecnologia não é mais uma extensão da visão humana frente aos fenômenos do mundo concreto, mas serve para materializar algo que foi pensado e/ou imaginado. Comentamos algumas obras que mostram como a tecnologia para criação de imagens constitui a própria ciência aplicada, ampliando não apenas o alcance do saber, como também a pluralidade da expressão visual.

Esta pesquisa debruça-se sobre imagens, desenhos, fotos, filmes no âmbito das ciências naturais e das engenharias, como sobre técnicas para observação de fenômenos invisíveis a olho nu, buscando exemplares de obras nos mais variados terrenos do saber científico. Não contemplamos filmes de ciências humanas, os psicológicos e etnográficos, porque abarcam fenômenos cuja interpretação/compreensão exige um arcabouço vasto teórico nesse campo, configurando uma ciência à parte. $\mathrm{O}$ cinema etnográfico comporta várias correntes, algumas conflitantes entre si, mas todas tentam recortar algum aspecto específico de uma comunidade ou de ensejar algum debate, o que faria desta uma outra tese.

A respeito das legendas nas imagens, o leitor perceberá que repetimos algumas informações que já apareceram no corpo do texto. Essa repetição é intencional, já que imaginamos que alguns visitantes da biblioteca podem folhear esta tese sem ter necessariamente o desejo de lê-la por completo, mas terão uma amostra do que o texto reserva. Em relação às traduções dos excertos citados, trata-se de tradução nossa, exceto quando indicada a edição da obra em português.

Outra escolha proposital foi a inserção de intertítulos em negrito e sem numeração para introduzir um subtema e dar fôlego à leitura. 
PARTE I 


\section{Capítulo I}

\section{As imagens no contexto científico - sensibilização e sedução do olhar}

Antes de falar do cinema científico, convém retomar um pouco da história da elaboração das imagens nas ciências, um percurso desenhado em linhas tortas, nem sempre coloridas, e que revela um pouco da evolução e do armazenamento do saber. O cinema científico herda uma série de tradições no que concerne à concepção, à realização e à veiculação de imagens no seio das disciplinas das ciências. Com uma produção absolutamente eclética em termos estéticos, temáticos e procedimentais, é possível estabelecer um diálogo entre as práticas deste cinema com as práticas de criação de imagens em contexto de exploração científica. Neste capítulo, observamos como a imagem e a ciência confundem-se e se complementam na constituição de uma cultura visual em três momentos e três dispositivos: ilustração, fotografia e cinema.

\section{I.I A pintura de ilustração como ciência de compreensão visual}

É um traço marcante da contemporaneidade a reflexão em torno da importância da informação visual em investigações de cunho científico. A necessidade da imagem na compreensão de fenômenos remonta à época das cavernas, com as representações das feras que poderiam ser ameaça ou alimento, das estações do ano, das cheias dos rios, dos maus agouros, enfim, dos ciclos da vida que estavam escritos na abóbada celeste e precisavam ser transmitidos através das gerações.

As formas de registro e transmissão do conhecimento constituíam uma escritura sem distinção entre arte e conhecimento até o final da Idade Média, época em que o saber começa a sair do monopólio da religião, e muito lentamente se pulveriza graças ao advento da imprensa.

A fabricação de imagens em botânica, zoologia, anatomia etc. é a forma mais antiga e difundida entre os instrumentos que mantêm afastada a subjetividade a que o texto desacompanhado pode remeter. A especificidade desta aproximação com as 
ciências reside nas práticas e na postura ante o objeto de estudo - o que se altera historicamente - a partir das quais a postura do cientista ganha um outro status.

Qual seria a finalidade das imagens à época em que foi produzida? Qual a qualidade que ela deveria portar para cumprir seu papel? E ainda, qual a postura do realizador ante o objeto estudado em relação à verdade contida em seu registro, sua ilustração?

A elaboração de ilustrações nas ciências abrange um conglomerado de problemas que passam pelo conhecimento e pela observação do estudioso, por sua habilidade ou a do seu colaborador, o artista, pela disponibilidade do objeto de estudo, pelas condições materiais para o registro, pelos conflitos individuais dos atores em questão, problemas esses que se multiplicam quando estudamos profundamente o contexto de cada obra.

Ao nos deter na observação dessas imagens e, em alguns casos, no modo como foram feitas e em que contexto (posto que as condições para se realizar um trabalho são determinantes para o resultado), é possível visitar pontos de inflexão no modo do pensamento. Os embates e tensões entre objeto e artista-cientista caracterizaram boa parte da história desse conhecimento.

Essas tensões remetem ao conceito de objetividade, algo que só se aproximou da pensamento científico em meados do século XIX, quando os cientistas se apaixonaram pelo registro mecânico, que àquela altura era visto como um meio de excluir a subjetividade do cientista. Segundo Daston e Galiston (2010), escrever uma história das imagens científicas é escrever, ao mesmo tempo, a história da objetividade e das virtudes epistêmicas que emergiram através dos tempos no campo dos estudos da natureza. Isso porque o conceito de verdade passa pelo critério do sujeito que vê, que estuda, conhece, escolhe e cria.

A ideia dos cientistas, ilustradores e cientistas-ilustradores de representar o mundo por meio das regularidades e dos tipos mais frequentes de uma determinada espécie/fenômeno almejava afastar o caos do mundo tal qual ele é, indescritível, cheio de irregularidades, de exceções. Na prática, o trabalho consistia em recolher e observar uma vasta quantidade de indivíduos da mesma espécie, observar-lhes as características comuns e retratar o indivíduo "ideal"; isso nem sempre significava ser fiel às incongruências e assimetrias da natureza, mas selecionar o que merece ser retratado por ser a média dos indivíduos. 
A complexidade desse processo vai além, dado o tamanho da empresa: o naturalista, estudioso, cientista ou o desenhista escolhe o exemplar que vai para a pose e o prepara, algo que necessariamente retira o objeto de sua condição natural da observação para que sirva ao propósito de ser um modelo, que irá figurar em publicações ou meios afins. Após realizado o desenho, vem o trabalho do gravador, sujeito altamente qualificado que prepara uma matriz a partir do desenho, o que constitui mais uma etapa entre a observação bruta e a impressão da imagem final.

\begin{abstract}
Ver - e, sobretudo, desenhar - era simultaneamente um ato de apreciação estética, seleção e acentuação. Essas imagens foram feitas para servir ao ideal da verdade - e frequentemente à beleza juntamente com a verdade - e não à objetividade, que ainda não existia. (DASTON; GALISON, 2010, p. 126)
\end{abstract}

Determinado assunto pode ser estudado por cientistas em todas as partes do mundo em uma mesma época; os atlas surgem então como compilações sistemáticas dos objetos de pesquisa nas ciências empíricas, mas um empirismo coletivo, com vários colaboradores. $\mathrm{O}$ atlas é um depósito das imagens de arquivo das ciências empíricas nos mais diversos domínios do conhecimento nas ciências naturais. Nesse sentido, chamar as imagens de "ilustrações" corresponde a subordiná-las ao texto, quando, no atlas, qualquer que seja o tamanho e o lugar do texto, as imagens é que são sua razão de ser e ocupam-lhe o lugar central.

$\mathrm{O}$ atlas é, portanto, a ciência destilada em publicações com credibilidade e consistência. É referência para os profissionais e educam o olhar de neófitos ao mostrar o essencial e o que merece atenção no objeto retratado. Em meados do século XIX, começo do século $\mathrm{XX}$, os atlas de bacteriologia, a partir de microscopia ou de radiografia, ensinaram a olhar um outro tipo de imagem (DASTON; GALISON, 2010).

Assim, os atlas de anatomia, botânica, zoologia, cartografia trabalhavam com uma diversidade de meios (gravura em couro, xilo e litogravura) e técnicas (desenho à mão livre, câmera escura), buscando sempre um exemplar idealizado, melhorado. Nesta prática, o cientista vê e o artista descreve, e o resultado é uma forma de saber coletivo e multidisciplinar, por meio de traços de um mundo que se torna visível a quatro olhos. ${ }^{2}$ O conceito que permeia a confecção do atlas é o da permanência, traço que delega a quem o faz a tarefa de julgar qual imagem é a que melhor representa as características

\footnotetext{
${ }^{2} \mathrm{Na}$ colaboração entre o cientista-naturalista e o desenhista, é o primeiro que leva o crédito e tem a última palavra. Os nomes dos desenhistas e dos gravadores apareciam em caracteres pequenos na parte inferior da página (DASTON; GALISON, 2010).
} 
ideais ou médias. O naturalista deve se despir de suas idiossincrasias, mas também destituir o objeto observado das suas idiossincrasias, porque a realidade - a natureza - é repleta de diversidade e de variações, mas a ciência precisa necessariamente escolher suas imagens. A qualidade do atlas resulta desse discernimento, assim como a amplitude e a profundidade das experiências retratadas. Assim, o atlas permite "conciliar o todo com o detalhe" (JACOB apud CASTRO, 2015, p. 25) e instigar a "meditação sobre o universo que representam" (CASTRO, 2015, p. 24).

Observando o devido lugar dessas publicações, abre-se caminho para visitar algumas obras de ilustradores - artistas científicos, que transcreveram sua observação do mundo para imagens, em práticas que não podem ser dissociadas do contexto histórico.

Até meados do século XIX, as ilustrações científicas eram a única maneira de retratar a natureza, os tipos humanos e paisagens, de transmitir e compartilhar essas informações. Expedições e viagens de exploração, como as do Capitão James Cook pelo Pacífico Sul, contavam sempre com cientistas naturalistas, artistas e encarregados de descrever espécies nunca antes vistas. Essa forma de retratar a vista da natureza, era mais fiel à realidade do que a pintura a partir de espécies embalsamadas e secas levadas às coleções. A visão a quatro olhos não é exatamente aquilo que os olhos veem, mas a justaposição da razão, da sensação e da imaginação (DASTON; GALISON, 2010, p. 119).

Além desses eventos, a presença do artista no local da pesquisa também se justifica em situações de uma patologia desconhecida, ou de um acidente geográfico em um lugar remoto, oportunidades raras para observar um fenômeno cuja descrição textual apenas seria insuficiente para oferecer a impressão da retina do observador. Nesse sentido, o texto enriquece a imagem, que é um trabalho manual transformado em intelectual, posto que é concebida para a reflexão.

Através de uma pequena mostra de cientistas-ilustradores, veremos os variados pontos de interesse da comunidade científica, sua relação com o conhecimento prévio e a evolução nas técnicas de figuração, o que evidencia que várias formas de olhar e documentar conviveram na mesma época, ou foram retomadas por outras. A ciência e a arte também são propulsores de rupturas em tradições estabelecidas.

Ainda hoje, cientistas consultam ilustrações antigas para entender como uma determinada espécie foi descrita pela primeira vez, ou buscam espécies que já foram extintas. Não raro, os ilustradores retratavam espécies que nunca tinham visto a partir de 
descrições de viajantes e de relatos transmitidos oralmente. Isto podia funcionar ou não como retrato, mas para o público carente de imagens de qualquer natureza, essas ilustrações serviam como referência.

No século XVI, o físico e botânico suíço Conrad Gessner publicou Historiae animalium (1551-1558), dividido em quatro volumes (quadrúpedes, anfíbios, pássaros e peixes). Há ainda um quinto volume sobre serpentes. Homem típico do Renascimento, Gessner foi também médico e professor de grego. Essa obra representou a primeira tentativa de mostrar o reino animal em descrições precisas e compreensivas. Gessner colecionava espécies e correspondências com relatos de amigos viajantes, e combinava suas observações com textos clássicos do Velho Testamento, de Aristóteles,e da cultura popular medieval. Trata-se de um trabalho idealizado, destituído de empirismo, já que para a maioria dos desenhos o artista não teve contato com os modelos.

A escassez de informação levou o desenhista a coletar o máximo de detalhes provindos de variadas fontes, e, com enorme esforço e auxílio de sua imaginação, foram produzidos "retratos falados" surpreendentemente semelhantes ao modelo original (exceto pelo unicórnio, que faz parte do reino mitológico) (figs. 3 e 4).
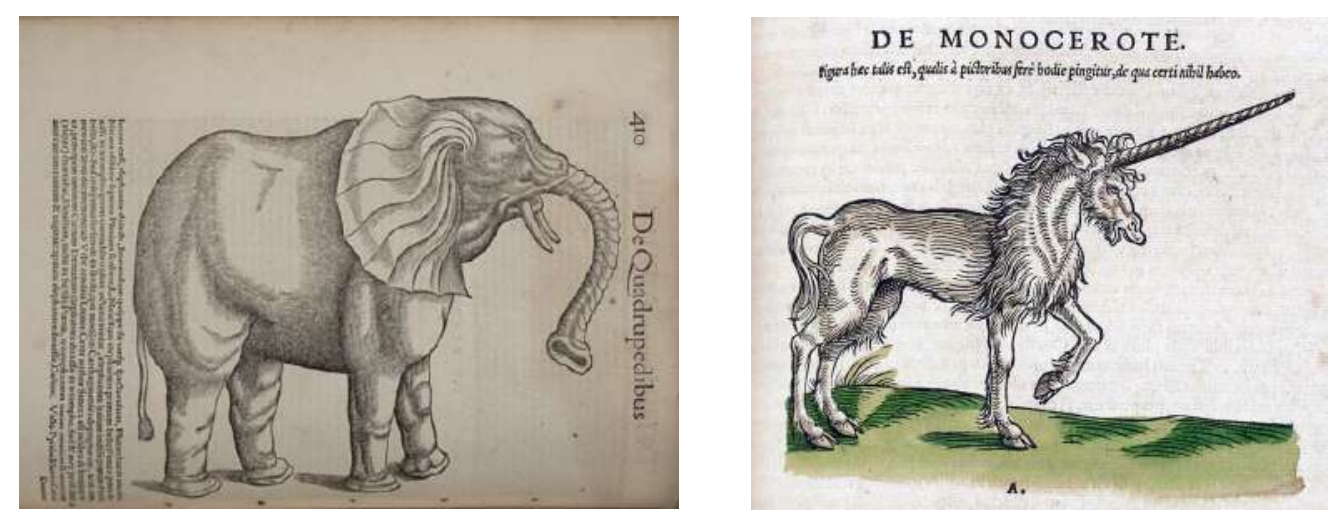

Figuras 3 e 4: Representações de elefante (ACADEMY OF NATURAL SCIENCES, s.d.) e unicórnio (HISTORIA ANIMALIUM, s.d.) a partir de relatos tomados oralmente.

Essas imagens carregadas de subjetividade correspondem a um mosaico de contribuições, nas quais crenças, história oral e folclore dividiam o mesmo valor no campo do conhecimento. As ilustrações do unicórnio e do elefante exemplificam o conceito de estado pré-científico pensado por Bachelard (definição, grosso modo, dada ao período que se estendeu da Antiguidade Clássica até início do século XVIII), caracterizada pela "experiência primeira, [...] revestida de sentimentos, impulsos, 
paixões, desejos inconscientes, fantasias, intuições, vaidade do saber" (BACHELARD, 1996 [1938], p. 17).

Até o final da Idade Média, em meados dos anos 1500, boa parte do conhecimento que se tinha da anatomia do corpo humano e das técnicas em medicina era baseada nas teorias do físico e filósofo grego Galenos Perganum, que dissecava animais (em geral macacos e porcos) ao invés de corpos humanos para deduzir a anatomia humana por analogia com esses mamíferos. Isso porque na antiga Grécia era proibida a dissecação de corpos humanos por motivos morais e éticos. Durante toda a Idade Média, era considerado heresia discordar de Perganum, e prevaleceram muitas práticas errôneas acerca do tratamento de doenças, calcadas em estudos equivocados desde o início; àquela altura, parecia razoável que os corpos vivos funcionassem todos seguindo as mesmas regras.

Leonardo da Vinci já era um artista reconhecido quando teve a permissão para dissecar cadáveres e produzir desenhos de anatomia completamente inovadores e fora do padrão de representação da figura humana até então. Em seu Manuscrito Anatômico $B$ (Cadernos Anatômicos datados entre 1485 e 1510), trabalhou em colaboração com o professor de anatomia da Universidade de Pavia, Marcantonio dela Torre, o que resultou em muitas descobertas inéditas no campo da anatomia e da fisiologia humanas. Os registros, tomados em nanquim e bico de pena, foram realizados durante duas décadas em que Da Vinci dissecou mais de trinta corpos (Fig. 6).
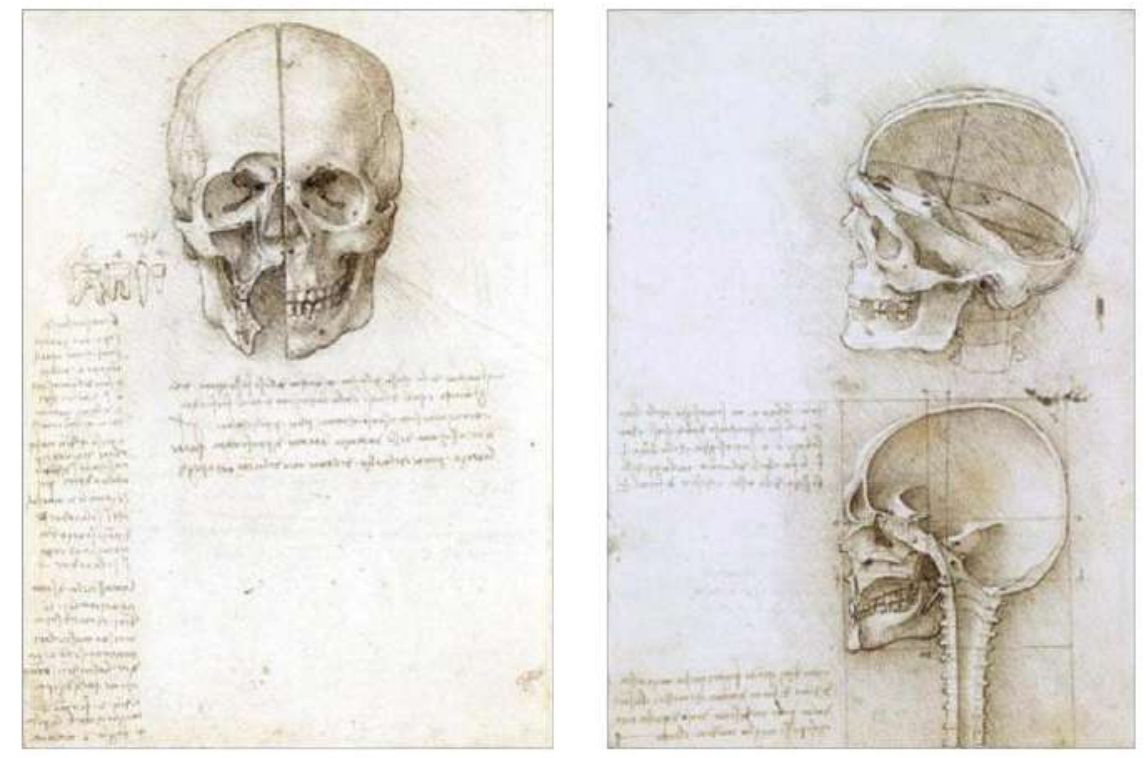

Figura 6: A acuidade no desenho é uma marca de Da Vinci, que valorizava o volume, a profundidade e a textura, além de selecionar o que é relevante, como observa Arnheim (ZÖLLNER, 2005. p. 85). 
Os desenhos científicos de Leonardo da Vinci são notáveis, porque ele entendia perfeitamente a estrutura e a função das coisas que representava e, ao mesmo tempo, era capaz de organizar padrões perceptivos complexos com a maior clareza. (ARNHEIM, 1980, p. 146)

O trabalho anatômico de Da Vinci situa-se a meio caminho entre seus interesses científicos e artísticos, e suas investigações fizeram com que a representação de estruturas ósseas e musculares passassem a ser obrigatórias aos estudantes de desenho, assim como a etimologia das palavras o é para os linguistas. A ciência de Da Vinci é uma ciência da compreensão visual, ou seja, seu utensílio é a aproximação visual dos fatos, e vários de seus desenhos testemunham sua ambição de "estabelecer o desenho na via real da ciência" (ZÖLLNER, 2005, p. 83). Assim, Da Vinci produz uma imagem que integra o belo e a verdade, em um processo de observação, escolha, comparação e síntese, porque somente copiar não seria suficiente, unindo subjetividade e acuidade artística.

A postura de Da Vinci inaugura a prevalência da imagem sobre a palavra no estudo da anatomia, o que é atestado pela gestão das legendas e explicações, e inaugura uma nova tendência nos estudos acadêmicos de sua época, os quais subordinavam as imagens ao texto. A continuidade de tal tendência é observada na obra de Andreas Vesalius, em que a ilustração ocupa lugar essencial. Médico e anatomista belga, Vesalius questionou várias proposições de Galenos Perganum ao confrontar suas dissecações com os estudos do naturalista grego.

A Igreja ainda condenava a prática da dissecação, mas passou a tolerá-la quando se tratasse de "cadáveres torturados, de sacripantas ou de protestantes, que jamais participariam da ressureição gloriosa do corpo" (SCHMIDT; DÉRIAZ, 2010, p. 208) (Fig. 5). A partir da dissecação e da comparação de corpos dos cemitérios com os escritos de Perganum, Vesalius pode demonstrar, com sua obra De humani corporis fabrica libri septem, ${ }^{3}$ mais conhecida como Fabrica, uma nova forma de representar o corpo, agora sim, humano, e mais: uma nova forma de transmitir o conhecimento.

Vesalius foi um dos precursores da ilustração científica, e sua obra, ilustrada com mais de duzentas figuras em xilogravura e constituída de sete volumes, foi a mais extensa e precisa descrição do corpo humano até então. É o início de uma cultura visual voltada para o conhecimento e o início de um compromisso com o que mais tarde

\footnotetext{
${ }^{3}$ Os sete livros sobre a estrutura do corpo humano, impresso em 1543.
} 
passou a ser chamado de objetividade. O trabalho incalculável de Vesalius não se limitava a encontrar cadáveres e dissecá-los, o que também fazia em sessões públicas para estudo e debate, o cuidado que tinha com a diagramação do texto e das imagens marcou a volta ao pensamento humanístico no campo da ciência e da arte.

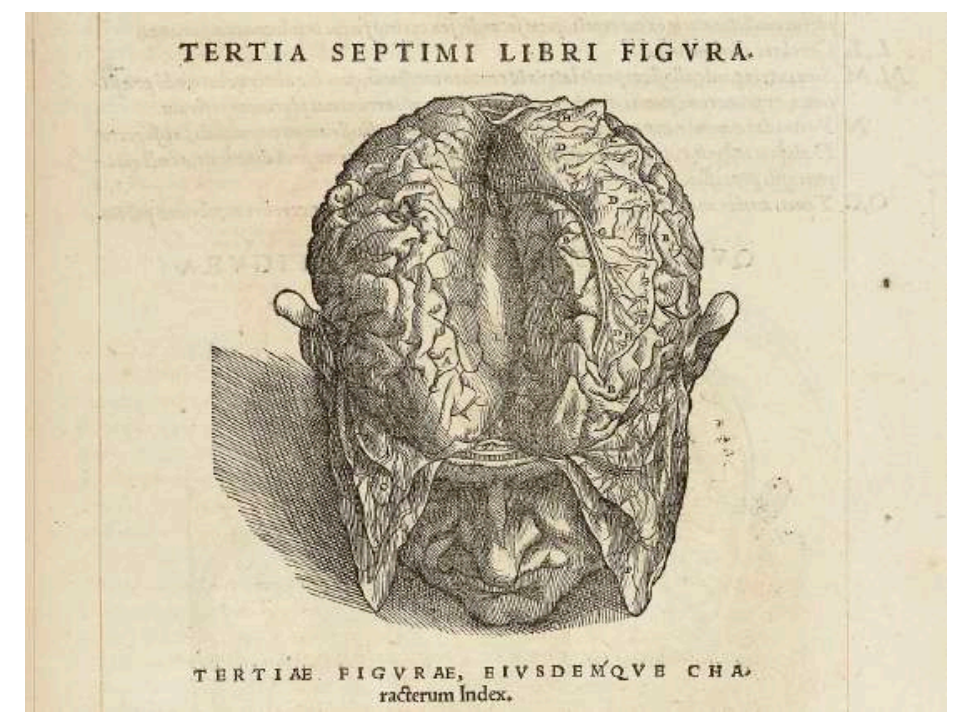

Figura 5: Xilogravura de corte transversal do crânio dissecado (SCATLIFF; JOHNSTON, 2005).

No século XVII, o filósofo, pedagogo e teólogo tcheco Iohannes Amos Comenius (também se encontra o nome Jan Amos Komensky) lançou as bases para a educação moderna publicando a obra Didactica Magna, em que valoriza o uso da imagem no processo de aprendizado. Comenius entende que: (1) aprender efetivamente é um processo que parte do simples para o complexo; (2) conhecer é transmitir na linguagem do interlocutor; e (3) compreender deve ocupar o lugar da memorização. Outra de suas obras, Orbis Sensuallium Pictus, ${ }^{4}$ é considerada o primeiro livro dirigido às crianças, uma publicação para o ensino de latim com instruções a respeito de variados assuntos da vida, recheado de desenhos em bico de pena. Nessa obra, além de enfatizar o uso da imagem, ele preconiza que deve haver prazer para um aprendizado eficaz.

Seguem alguns parágrafos de Comenius (1659, p. 13):

Onde os fundamentos de todas as coisas que se aconselham são tirados da própria natureza das coisas; a sua verdade é demonstrada com exemplos paralelos das artes mecânicas. [...] A proa e a popa da nossa Didática será investigar e descobrir o método segundo o qual os professores ensinem

\footnotetext{
${ }^{4}$ A World of Things Obvious to the Senses Drawn in Pictures, segundo a tradução inglesa.
} 
menos e os estudantes aprendam mais. [...] Nós ousamos prometer uma Didática Magna, isto é, um método universal de ensinar tudo a todos. E de ensinar com tal certeza, que seja impossível não conseguir bons resultados. $\mathrm{E}$ de ensinar rapidamente, ou seja, sem nenhum enfado e sem nenhum aborrecimento para os alunos e para os professores, mas antes, com sumo prazer para uns e para outros.

É interessante notar que, no Prefácio, Comenius comenta que o conteúdo do livro encerra figuras (pictura) e nomenclaturas (nomenclaturae): as figuras são representações de todas as coisas visíveis no mundo e as nomenclaturas são as legendas (Fig. 6). Apesar de Comenius se fundamentar na permissão divina, seu método foi perseguido pela igreja, uma vez que universalizava o direito do aprendizado a qualquer ser humano, não importando sexo, idade, nacionalidade ou estrato social.

[...] Apenas podiam adquirir, à força de lutar, uma instrução sólida aqueles que tinham a felicidade de possuir uma inteligência divina. [...] Deus começou a propiciar-se do século nascente, verdadeiramente novo, direi, quase uma aurora, e suscitou, na Alemanha, alguns homens de bem que, desgostosos com a confusão dos métodos utilizados nas escolas, se puseram a investigar um método mais curto e mais fácil para ensinar as línguas e as artes. (COMENIUS, 1705, p. 17)

[...] Será da maior utilidade, para o nosso objetivo, que se pinte nas paredes das aulas o resumo de todos os livros de cada classe, tanto o texto (com vigorosa brevidade), como ilustrações, retratos e relevos, pelos quais os sentidos, a memória e a inteligência dos estudantes sejam, todos os dias, estimulados. Com efeito, não foi sem razão que os antigos nos transmitiram este processo; nas paredes do templo de Esculápio estavam inscritas as regras de toda medicina as quais Hipócrates, entrando lá às escondidas, copiou. (COMENIUS, 1705, p. 314)

Figura 6: Página interna de Orbis Sensuallium Pictus, que traz o verbete "convidar" em latim e em inglês (COMENIUS, 1705).

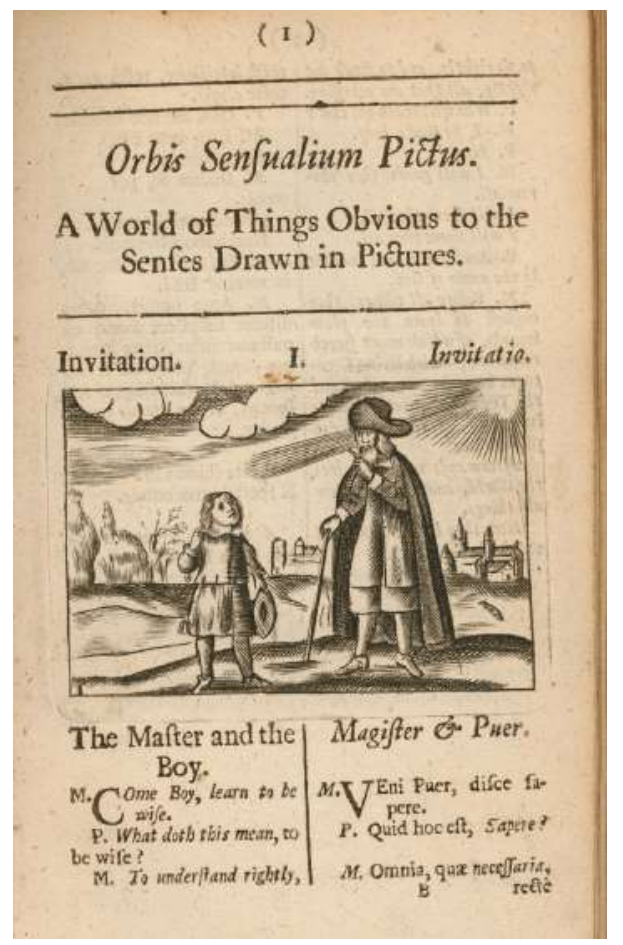


A obra de Comenius faz parte do pensamento humanista que emergia na Europa ao final da Idade Média, instaurado pelo desenvolvimento da imprensa e pela Reforma Luterana no século XVI, época em que a obra de Copérnico começou a ganhar visibilidade, bem depois de sua morte. Esse caldo cultural é bem descrito por Arthur Koestler em $O$ homem e o universo (cujo primeiro título foi Os sonâmbulos), obra que narra a evolução das concepções de universo. Na passagem que relata a hesitação de Copérnico antes de publicar sua obra, Koestler (1989 [1938], p. 89) escreve:

\begin{abstract}
O pulso da humanidade ia-se apressando como se o nosso planeta, após atravessar, na viagem pelo espaço, uma zona sonolenta e entontecida do universo, estivesse emergindo numa região banhada de raios vivificantes ou repleta de benzedrina cósmica no pó interestrelar. [...] As glândulas humanas pareciam produzir um novo hormônio causador do subitâneo aparecimento de uma nova avidez: a curiosidade, a curiosidade inocente, voluptuosa, criadora, destruidora, canibalesca, da criança.
\end{abstract}

Outro ilustrador/pesquisador foi Robert Hooke, exemplo de homem renascentista de múltiplas habilidades. Arquiteto, biólogo, astrônomo, pioneiro em cartografia e inventor, acredita-se ser o primeiro a produzir ilustrações com auxílio de microscópio um adaptado, equipamento que ele desenvolveu e descreveu em pormenores. Para sua obra Micrographia (1665) (Fig. 7), ele observou e desenhou objetos familiares, como fios de cabelo com piolho, mosca, fungo no pão, assim como detalhes de tecidos, de folhas de plantas e cristais de água. Hooke expõe sua intenção de reparar erros e enganos produzidos pela superstição e pela negligência das leis da natureza.
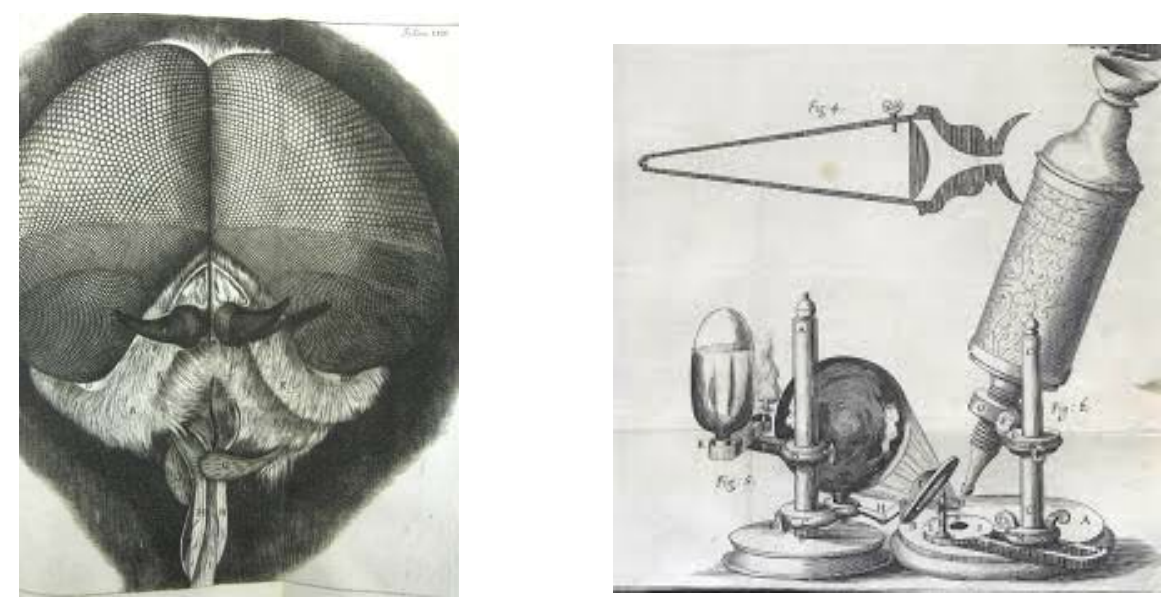

Figura 7: Ilustração da cabeça de uma mosca ampliada, extraída de sua obra Micrographia. À direita, o equipamento desenvolvido por Hooke para executar seu trabalho (HOOKE, 2003). 
Seu método de pesquisa empregava experimentos e dispositivos (microscópio, por exemplo) para estender as "operações dos sentidos, da memória e da razão" (HOOKE, 2003, p. XX), numa contribuição efetiva para a história da ética epistêmica na representação científica. Outro aspecto transformador foi de que a mudança de perspectiva e de escala alterou os objetos do cotidiano ou animais repulsivos em imagens de beleza surpreendente.

As ilustrações científicas, principalmente as botânicas, constituíram um nicho de oportunidade para a participação feminina. A ilustradora alemã Maria Sibylla Merian, também conhecida como Anna Maria Sibylla, foi uma precursora do trabalho feminino na ciência. Naturalista e pintora, sua curiosidade pela natureza levou-a a publicar dois livros com ilustrações botânicas e de insetos - bichos da seda, lagartas e borboletas (Fig. 8). Sua viagem ao Suriname no século XVII foi uma das primeiras expedições científicas para a América Latina. Nela, Merian catalogou dezenas de espécies e retratou o ciclo completo da metamorfose das lagartas em borboletas, numa época em que ainda se acreditava em geração espontânea: alguns insetos derivam a partir de matéria orgânica podre. Elogiada por Goethe por sua habilidade em se deslocar entre arte e ciência, entre observação e intenção artística, Merian é considerada a primeira ilustradora a retratar as relações entre os insetos e as plantas, bem como sua luta pela sobrevivência na natureza.
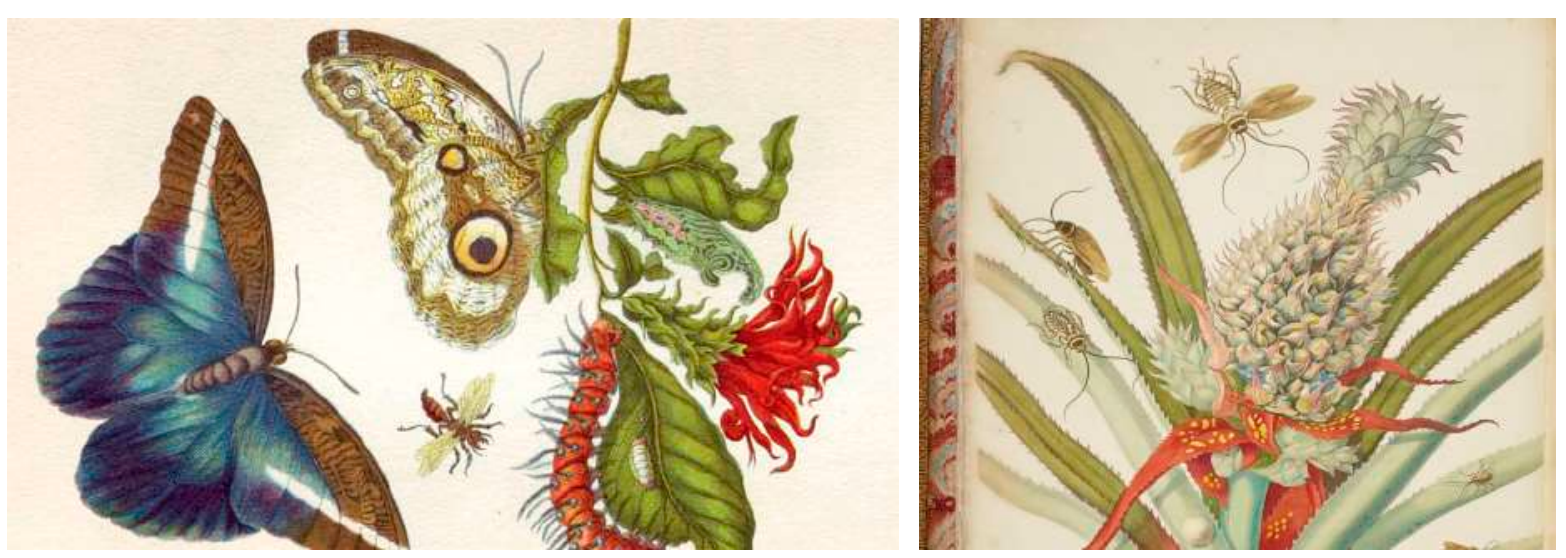

Figura 8: Aquarelas de Maria Sibylla Merian para Metamorphosis insectorum Surinamensium, 1705. Muitas vezes Merian compõe cenas artificiais que mesclam características fiéis das espécies retratadas com ambientes inventados - a partir de referências reais, na busca pelo exemplar ideal, a imagem que melhor representa a espécie (ROYAL COLLECTION TRUST, s.d.).

Maria Sibylla Merian encabeça uma tradição de ilustradoras, sobressaindo-se por ser, ela mesma, uma cientista-naturalista. Em muitos casos, as ilustradoras eram 
esposas, filhas e irmãs do naturalista com quem trabalhavam, em uma relação de total dependência, quase uma servidão doméstica (DASTON; GALISON, 2010, p. 108). Elas eram formadas desde a infầncia para atender ao mestre a quem se subordinavam, e paradoxalmente não era raro se tornarem melhores observadoras das espécies retratadas. Havia também as ilustradoras profissionais, que eram muitas vezes excluídas da pintura de mais prestígio, como as religiosas e as historiadoras, para se dedicarem às naturezas mortas e à ilustrações de história natural.

Outro naturalista, o entomologista Moses Harris, foi também um pintor de talento. Com uma imensa bagagem no ramo da ilustração de insetos, sua grande contribuição deu-se na observação dos fenômenos da luz e da cor. Influenciado pelos estudos de Isaac Newton, realizados cem anos antes, Harris buscou entender a relação entre as cores e como se dá sua percepção, o que lhe permitiu estabelecer princípios de harmonia a partir das escalas cromáticas aplicadas à pintura. Isso sugere sua preocupação em relação a estados emocionais acionados pela exposição a diferentes cores.

Antes de Harris, outros cientistas já haviam proposto esquemas cromáticos, mas o trabalho de Harris com pigmentos tornou-se referência para pesquisadores que o sucederam por ser o mais completo até então e por demonstrar, em um diagrama circular, que as cores primárias são vermelho, azul e amarelo, as secundárias, laranja, roxo e verde. Também mostrou como, a partir dessas tonalidades primárias, uma multitude de cores pode ser criada.

Ele compreendeu o fenômeno da absorção e da reflexão da luz em diversas superfícies, propondo os esquemas cromáticos por adição e por subtração de luz. O esquema cromático por adição corresponde à formação das cores a partir da incidência dos espectros vermelho-verde-azul que, somados, resultam na luz branca, enquanto que o esquema cromático por subtração refere-se às combinações dos pigmentos cianamarelo-magenta, que, somados, resultam na cor preta, ou seja, um pigmento que absorve todos os espectros da luz branca.

A Roda de Cores, desenvolvida entre 1766 e 1770, presente em seu Natural System of Colours, foi o primeiro esquema de composição de cores primárias, secundárias e terciárias (Fig. 9). A ciência das cores é uma aliança potente entre a física, a fisiologia e a psicologia (DASTON; GALISON, 2010, p. 320), e, mais tarde, no final do século XIX, ela suscitava questões de ordem psicossensorial que confrontavam a objetividade do mundo exterior com a subjetividade do mundo interior, reforçando o 
debate entre empiristas, filósofos e cientistas acerca de uma verdade passível de ser comunicada.

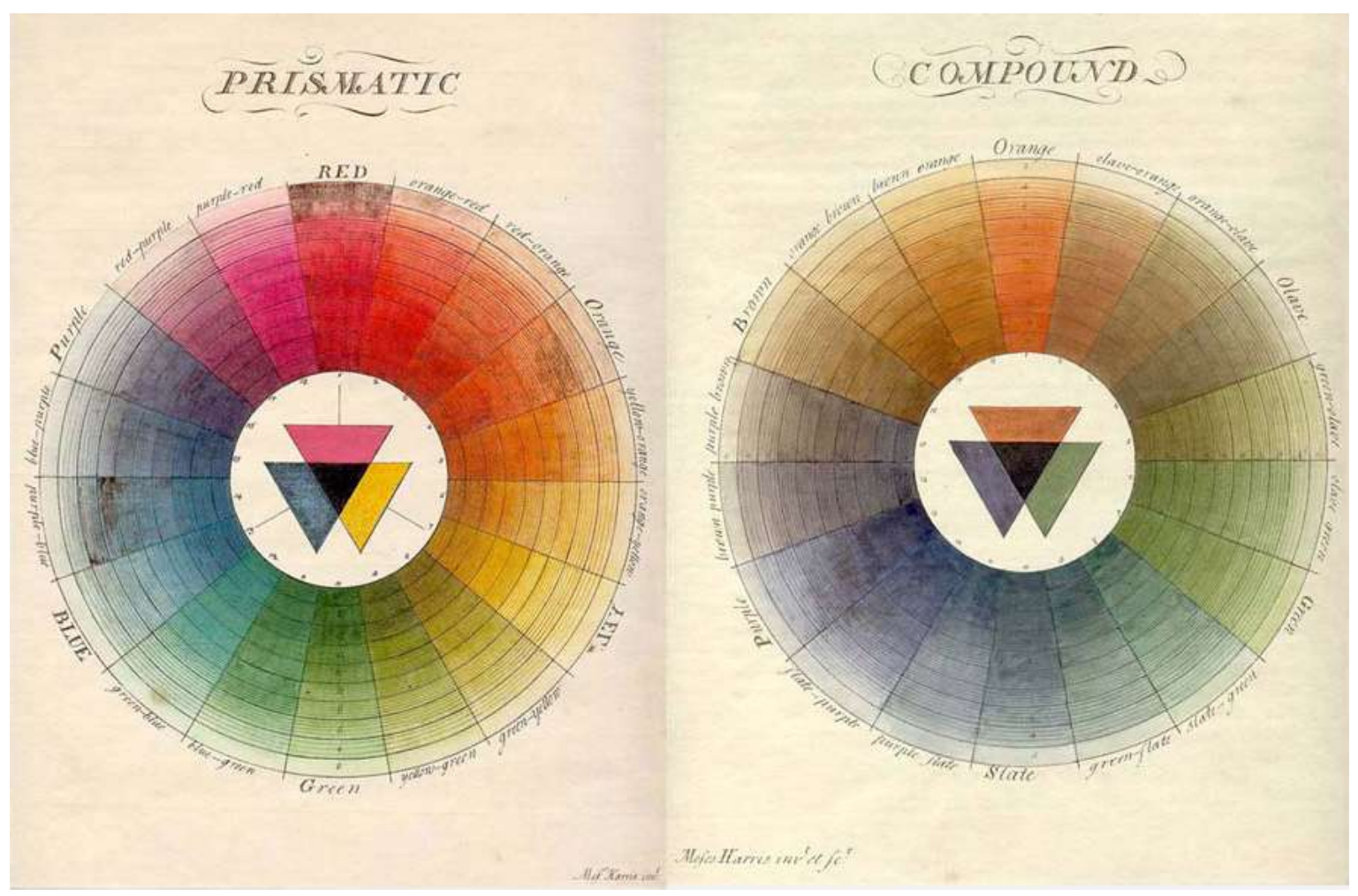

Figura 9: O disco de cores de Moses Harris foi a primeira sistematização das cores que compõem o espectro da luz solar (HARRIS, [1785).

Nos desdobramentos do estudo das cores, O tratado das cores, de Johann Wolfgang von Goethe, é um documento incontornável no que diz respeito à conexão entre a ciência, os estudos em psicologia e a arte. Goethe teve o insight para o efeito sensual-moral das cores; assim, as cores assumiam qualidades, iniciando com a oposição elementar entre luz e escuridão (o que não fazia parte da pesquisa de Newton), e entre quente e frio. $\mathrm{O}$ amarelo pode expressar luz, brilho, força, calor, atração. O azul seria a escuridão enfraquecida pela luz. Para ele, os fenômenos objetivos e subjetivos do processo da visão são complementares.

O processo empírico de observação dos fenômenos relativos à incidência da luz é também um processo de abstração. A ideia de que a percepção das cores entre diferentes indivíduos não é uniforme toma corpo nessa época. Esses estudos não se restringiram ao campo da fisiologia, mas passaram também pela história, pela psicologia e pela etnografia, com cientistas procurando entender como se dá a 
percepção das cores entre diferentes povos. O estudo da luz e das cores foi, portanto, campo propício para uma visão mais integrada de uma ciência baseada em experimentos e cálculos com uma área do saber que ainda não se definia como ciência, mais próxima da filosofia e da compreensão do comportamento, a psicologia.

A postura do ilustrador científico foi ocasionalmente o centro de rivalidades e controvérsias, principalmente no final do século XIX, com a possibilidade do registro mecânico. A partir de então, a ideia de objetividade passa a responder a outros critérios de validação. Se antes as convenções de representação visual impostas pelo meios técnicos resultavam em idealizações e distorções, agora a acuidade nos detalhes de uma imagem produzida pela câmera fotográfica poderia trazer novos significados e interpretações.

A subjetividade do cientista, com suas convicções, seus métodos e seu julgamento, poderia transformar o seio de um laboratório em um campo de disputas em que as imagens serviriam de testemunha a favor de uma ou de outra hipótese. Santiago Ramón y Cajal e Beatrix Potter protagonizaram histórias tumultuadas envolvendo a criação, a distorção e a interpretação de imagens de acordo com hipóteses nem sempre corretas.

O espanhol Santiago Ramón y Cajal, no século XIX, já era habilidoso pintor e desenhista quando entrou para a faculdade de medicina, incentivado por seu pai, também médico. Juntos, iam ao cemitério próximo roubar cadáveres, os quais eram dissecados para que Cajal fizesse seus desenhos. Direcionando o estudo para a área da neurociência, Cajal aperfeiçoou o método de Camilo Golgi ${ }^{5}$ (seu concorrente e rival), pelo qual se usava dicromato de potássio e nitrato de prata impregnados no tecido do sistema nervoso para tornar os neurônios mais destacados ao microscópio - equipado com os mesmos espelhos de uma câmara clara -, o que permitiu retratá-los de um modo como nunca se havia feito. "Toda sua vida, Cajal escreveu sobre a luta para encontrar um meio de 'ver claramente'. Esse termo impregna todos seus escritos científicos, seus trabalhos em laboratório, suas reflexões autobiográficas, e mesmo seus textos de ficção" (DASTON; GALISON, 2010, p. 142). Sua preocupação em afastar a interpretação e a imaginação traziam um aspecto ético em relação ao objeto de estudo. Daí sua discórdia com Golgi, que, segundo Cajal, teria alterado de propósito a imagem que vira no microscópio para justificar sua teoria da transmissão dos impulsos entre os neurônios.

\footnotetext{
${ }^{5}$ A respeito da rivalidade enre Cajal e Golgi e sua discussão durante o prêmio Nobel de 1906, ver Daston e Galison, 2010, p. 139 e 214).
} 
A partir de suas observações, Cajal pôde descrever as estruturas das células cerebrais e a anatomia do neurônio, mostrando a imbricada rede de ramificações neuroniais e suas conexões (Fig. 10). Suas ilustrações serviram de base para os estudos em neuropatologia e em neurociência. Por sua contribuição nesse campo, recebeu o prêmio Nobel em 1906.

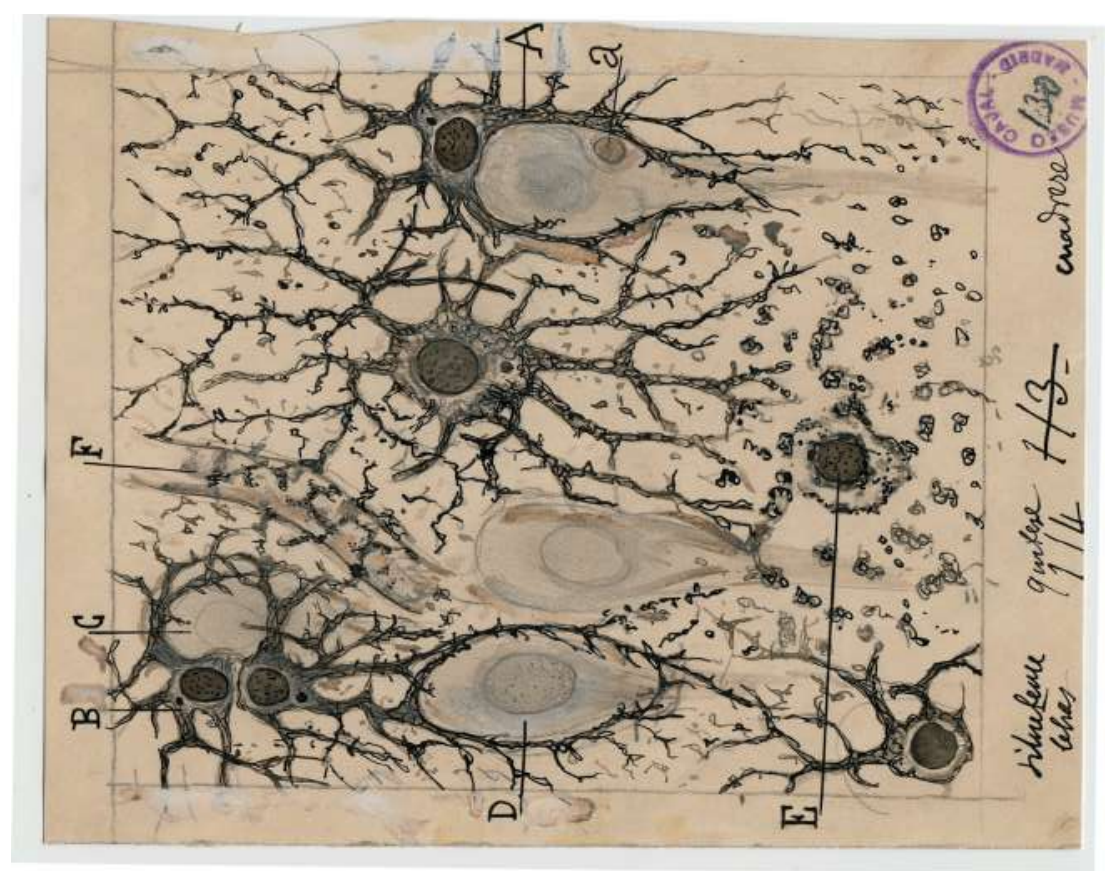

Figura 10: Astrócitos no hipocampo do cérebro humano, 1899. As imagens produzidas por Cajal revelam seu esforço em interpretar e representar com a máxima fidelidade o tecido nervoso, entregando o objeto de estudo com a mínima interferência humana, como ele se apresenta na natureza. A interpretação do cientista vai dar sentido a uma imagem semelhante, a uma textura abstrata (MIND MAPS, 2017).

Beatrix Potter, ${ }^{6}$ ilustradora e pesquisadora na área da micologia no século XIX, interessava-se por praticamente todos os campos da ciência, exceto astronomia. Ela colecionava e estudava tudo que encontrava ao seu redor, desde fósseis a objetos arqueológicos. Seu interesse primordial, contudo, era pelos fungos e por todo tipo de cogumelos, os quais aprendeu a cultivar e a observar pelo microscópio, para depois retratar em centenas de aquarelas primorosas (Fig. 11). Sua dedicação e seu aprendizado, contudo, permaneceram na esfera do amadorismo, sem o rigor científico exigido pela academia. Entusiasta e ousada, Potter desafiou uma sociedade científica elitizada e fechada à presença feminina, e expôs suas aquarelas na crença de que seus

\footnotetext{
${ }^{6}$ Autora de literatura infantil, criadora do personagem Peter Rabbit, de 1902.
} 
estudos em torno da germinação dos esporos (unidades de reprodução das plantas) fosse pioneiro. Não há consenso quanto a possíveis descobertas de Potter, mas sua contribuição artística segue como referência, tanto no aquarelismo botânico, como para o reconhecimento de dezenas de espécies de fungos.

Após várias tentativas de ser reconhecida no meio científico, Potter alcançou projeção na literatura infantil, para onde levou todo seu conhecimento da natureza na criação de personagens em narrativas fantasiosas, nas quais coexistiam imaginação e realismo. "Tudo vem da natureza", sentenciou David Hockney em 2013, atualizando o pensamento que guiava a prática de muitos artistas, e que também orienta a busca da ciência por respostas.

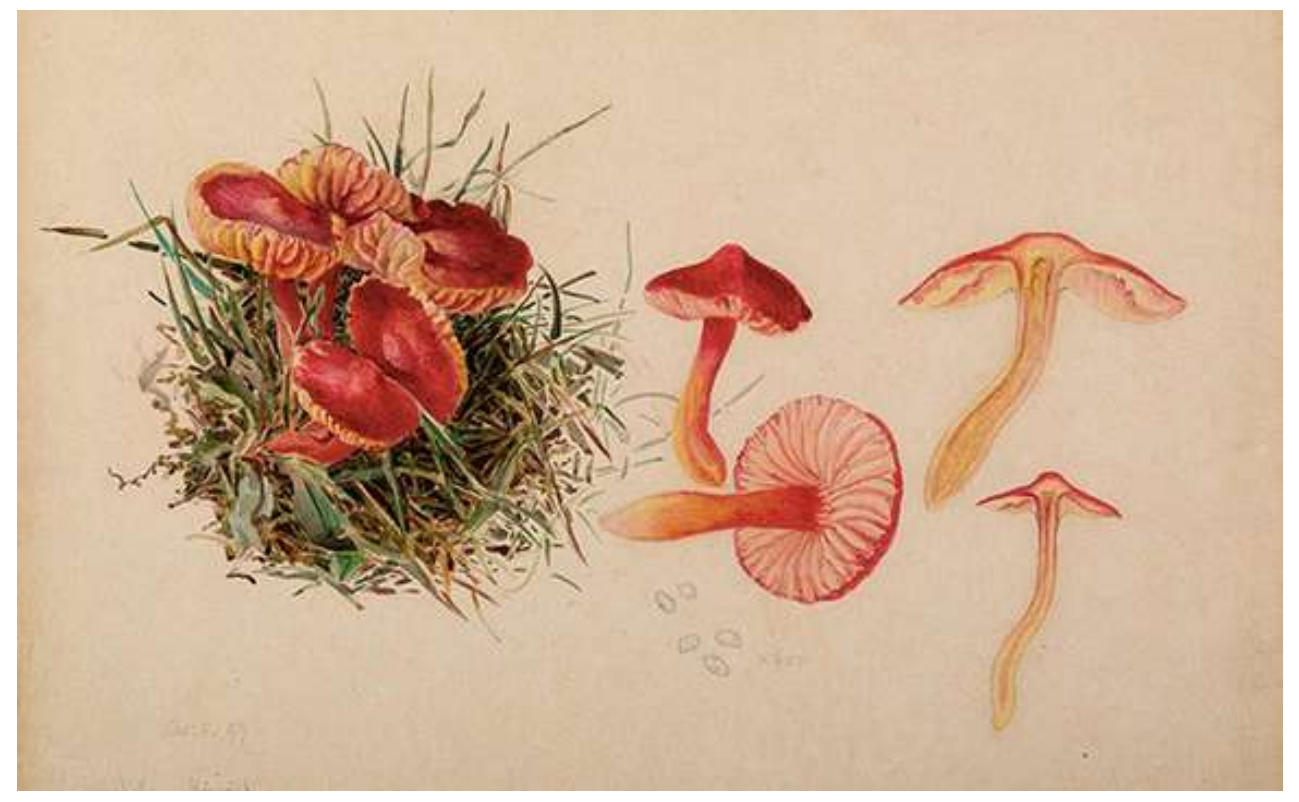

Figura 11: Sistema reprodutivo da Hygrocybe coccinea, 1897. Potter costumava retratar na mesma lâmina o fungo em seu habitat natural ao lado de algumas fases do seu desenvolvimento e um corte transversal, buscando registrar o exemplar da forma mais completa (BEATRIX POTTER, s.d.).

O museu americano de História Natural guarda um imenso acervo de obras científicas ilustradas, desde o século XVI. Recentemente, reuniram-se alguns exemplares dessa coleção em um volume comentado por ensaístas de artes e de ciências, e editado por Tom Baione chamado Natural Histories: extraordinary rare book selections from the American museum of natural history library (livro do Museu de História Natural - EUA). Cada ilustração é acompanhada do contexto em que foi produzida, e o conjunto da obra revela não apenas a evolução das técnicas de registro e de impressão, mas também como determinadas espécies foram descritas pela primeira 
vez, o que abre a discussão sobre a construção do conhecimento em relação a todas as disciplinas e às artes.

Dezenas de outros artistas-cientistas, ou naturalistas, trabalhando a quatro olhos com seus ilustradores-colaboradores, não foram citados neste panorama da ilustração nas ciências. Os embates em torno da possível verdade científica eram constantes e impunham dilemas ético-epistemológicos que poderiam, conforme o caso, invalidar um trabalho ou uma tese, já que a interpretação do objeto visto, a compreensão, o julgamento do fenômeno e sua transposição para o papel constituíam um processo sofisticado de produção de conhecimento.

Nesse sentido, pelo ponto de vista do cientista-pesquisador, é certo que as imagens (fotográficas ou desenhadas) assumiram importância equivalente à do texto. A discussão em torno da intervenção no objeto estudado e no seu modo de representação intensifica-se com o uso da câmera fotográfica nos ambientes de pesquisa, já que o registro mecânico tende a conferir veracidade, testemunhar documentalmente e, portanto, afastar a intervenção.

Do ponto de vista da transmissão do conhecimento (ensino-aprendizagem), a imagem é percebida como eficiente porque afeta o observador imediatamente, enquanto que a palavra precisa ser lida ou falada para depois ser processada cognitivamente. $\mathrm{Na}$ imagem há, portanto, um meio físico assimilado imediatamente pela visão, enquanto que na palavra há uma experiência mais mental e intelectual (GAYCKEN, 2015, p. 110). A primeira consequência desta ideia até os dias de hoje é que a imagem tem menos valor do que o texto escrito, porque recorre menos à inteligência e à capacidade de processamento de informação. E é menos exigente em termos de compreensão, ocupando um lugar hierarquicamente inferior ao texto na maioria das disciplinas. Logo mais, ao falarmos da cinematografia científica em sua função pedagógica, veremos que, na discussão sobre a eficácia ou não do meio visual não há um consenso.

\section{I.II Fotografia - o olho mecânico e preciso como espelho do real}

A fotografia - derivada ela mesma de experimentos e pesquisas - retribuiu ao seio da ciência uma infinidade de possibilidades na forma de evidências, testemunhos e novas perspectivas. A seguir, traçaremos um percurso em que o progresso na vida urbana e na ciência modificaram a visão científica - na direção da exatidão do 
conhecimento, e a visão artística - no sentido da emancipação das possibilidades de expressão criativa. Buscaremos entender em paralelo o desenvolvimento tecnológico e a formação de uma cultura visual alimentada por fontes e visões de mundo heterogêneas.

$\mathrm{Na}$ segunda metade do século XIX e início do XX, as ilustrações ainda continuavam a dar conta de representar e compartilhar uma série de conhecimentos e disciplinas. Portanto, o advento da fotografia não substituiu o trabalho do ilustrador em nenhuma área: em botânica, entomologia e medicina, principalmente, os desenhos continuaram a figurar nos atlas. Em muitos casos, o desenho mostra aquilo que é preciso ser visto, isola a figura do fundo, salienta-a e a enfatiza, algo que a fotografia por si só não faz. A fotografia pode ser um meio demasiado explícito de apresentar imagens. Fotografias de cirurgias, por exemplo, podem resultar em imagens repulsivas, com sangue, pus, órgãos deteriorados. Já as ilustrações podem cumprir seu papel pedagógico sem o aspecto repugnante. O realismo fotográfico, neste caso, é substituído por graus de estilização que o desenho de ilustração proporciona.

Em meados do século XIX, no centro do mundo ocidental, a revolução industrial já estava consolidada; a busca pela eficiência levava a toda ordem de pesquisas que trouxessem melhorias nas máquinas e nos processos. O método científico se instaura como o padrão a ser seguido na busca pela verdade, sempre indexada à realidade objetiva e concreta. O "ver para crer" não sustenta mais, por si só, o espírito científico, o qual pode ter na visão sua ferramenta primária, mas exige esforço de elaboração abstrata para criar leis válidas aplicáveis para um mesmo fenômeno.

\footnotetext{
Sobre qualquer questão, sobre qualquer fenômeno, é preciso passar primeiro da imagem para a forma geométrica e, depois, da forma geométrica para a forma abstrata, ou seja, seguir a via psicológica normal do pensamento científico. (BACHELARD, 1996 [1938], p. 11)
}

Surge, portanto, na classe científica, a preocupação de que o maior obstáculo à aquisição do saber são os próprios cientistas. Constatou-se que eles incluem sua individualidade e suas percepções dos fenômenos. O percurso pensado por Bachelard responde aos julgamentos subjetivos que poderiam levar a distorções no compartilhamento do conhecimento.

O interesse pelo universo das ciências, engenharias, novas formas de energia e natureza do movimento eram comuns à academia e ao cidadão comum, que assistia à troca da iluminação a gás pelas lâmpadas elétricas, à onipresença das máquinas a vapor, 
ao traçado das ferrovias para encurtar caminhos e ao surgimento das revistas ilustradas tendo o suporte da tipografia moderna.

Antes do surgimento da fotografia, a percepção visual e a persistência da imagem na retina já eram temas recorrentes em pesquisas; os "brinquedos óticos", pequenos espetáculos domésticos em efervescência nos centros urbanos, derivaram de experimentos de cientistas e também de curiosos em matemática, fisiologia, física. Já havia o entendimento de que todo processo ótico é um fenômeno dinâmico que conjuga os processos físico e mental da visão; muitos desses equipamentos serviram mais tarde para o design de câmeras e lentes, e para o cálculo da velocidade de projeção das imagens. Esse volume de pesquisas formais e informais tem a ver com a sociedade industrial e com o "mito da máquina como instrumento de progresso [...] e máquina significa movimento" (TOSI, 2005, p. 29).

Entre as décadas de 1820 e 1830, vários experimentos em torno da captura e da fixação da imagem estavam em andamento. Logo no início, a fotografia foi posta a serviço das ciências em três regimes: mostrar com precisão os detalhes de algo já conhecido, revelar algo desconhecido e testemunhar eventos.

O processo fotográfico desenvolvido ao longo do século XIX abrangeu um largo espectro de inventos e de técnicas com resultados diferentes. Louis-Jacques Mandé Daguerre, reconhecido como um dos pioneiros do processo de gravação por meio da luz, ganhava a vida como pintor de panoramas antes de obter sucesso com imagens surpreendentemente bem definidas, gravadas em placa de prata polida (ou em couro revestido de prata). Dando continuidade às pesquisas de Nicéphore Nièpce e até colaborando com ele, Daguerre buscou acertar a equação da exposição do material sensível. A longuíssima exposição dos registros iniciais de Nièpce (não se sabe ao certo, entre 10 horas e dois dias de exposição), limitava a gama de temas a objetos inanimados com iluminação natural, por exemplo, uma natureza morta, uma construção arquitetônica.

À medida em que o tempo de exposição foi-se reduzindo, pôde-se avançar à captura de retratos, que necessitavam de alguns minutos. Gradualmente, a melhoria do material sensível, da óptica do dispositivo e dos químicos possibilitaram, primeiro, a captura de imagens em deslocamento lento, como um veleiro ou uma paisagem, para os quais um quarto de segundo era suficiente, e finalmente, com instantâneo, foi possível congelar deslocamentos rápidos, como o galope do cavalo, um salto com vara ou uma locomotiva. 
A exposição de longa duração, portanto, vincula-se à ideia de um tema "posado", enquanto que o instantâneo traz a ideia da espontaneidade, do "ao vivo", do flagrante. Como veremos mais tarde, a questão do tempo coloca-se em um lugar central, tanto no plano procedural/metodológico, como no plano epistemológico/ontológico do registro de imagens. O advento do instantâneo fotográfico constitui, pois, etapa essencial para o desenvolvimento das cronofotografias.

Paralelamente a Daguerre, outros homens de formações profissionais heterogêneas empreenderam tempo e dinheiro em busca da captura e da impressão de imagens, obtendo diferentes resultados. O invento de Daguerre, por exemplo, não permitia múltiplas reproduções a partir de uma mesma placa. Henry Fox Talbot e John Herschel complementaram a técnica de Daguerre: o produto da exposição do papel fotossensível à luz era uma imagem que Herschel chamou de "negativa", a partir da qual poderiam, por contato, produzir várias imagens "positivas". Vale dizer que Talbot, pouco talentoso para o desenho e interessado na possibilidade artística da produção mecânica de imagens, aliou-se ao astrônomo e físico John Herschel, mais interessado nas propriedades da luz; ambos, contudo, interessados na precisão e na captação de detalhes.

A busca pela representação objetiva como tentativa de "libertar a imagem da interferência humana" (DASTON; GALISON, 2010, p. 121) encontrou no registro mecânico da câmera fotográfica uma solução com potencial para eliminar a interpretação do cientista/artista, que na visão da época poderia testemunhar uma imagem exata do objeto estudado. Contudo, para ser aceita como registro objetivo e científico, foram necessários ajustes metodológicos adequados às diversas disciplinas. Nessa seara se insere o trabalho de Etienne-Jules Marey, que estabeleceu os paradigmas pelos quais o dispositivo fotográfico se inscreveria definitivamente na ciência.

O salto do leopardo em câmera lenta ou o desabrochar de uma flor são imagens relativamente banais nos atuais veículos de comunicação. A saturação de imagens no mundo contemporâneo torna difícil imaginar o deslumbre do cidadão que viveu há 150 anos frente à reprodução mecânica da imagem de um objeto real.

Enquanto se buscavam materiais e métodos para contornar a questão da baixa sensibilidade da película ou do papel fotográfico, que impedia o uso da fotografia em estudos de movimento (dada a necessidade de longa exposição), muitas tentativas foram feitas em relação à reprodução mecânica de imagens coloridas e estereoscópicas. 
O sonho da fotografia instantânea era tão longínquo que ainda não se considerava "parar" um movimento na placa fotográfica. Mesmo assim, Plateau, ${ }^{7}$ que já era cego em 1849, usou dois daguerreótipos lado a lado para fotografar pequenos objetos em movimento estereoscopicamente. (TOSI, 2005 , p. 30)

$\mathrm{Na}$ maioria dos casos, quando os cientistas precisavam produzir imagens, as opções seriam: contratar um ilustrador ou fotógrafo, conforme a época, ou lidarem eles mesmos com a questão do registro. Imaginando o devir dos processos que levariam ao cinema, inventores das mais variadas formações começaram a registrar patentes de equipamentos que nunca existiram em forma de protótipo, mas que contavam com detalhadas descrições, até mesmo das funcionalidades especiais, como

\begin{abstract}
Condensar em poucos instantes uma cena que na realidade acontece em um considerável espaço de tempo, por exemplo o nascimento de plantas e árvores e todos os fenômenos de vegetação, a passagem de uma estação para outra, [...] a construção de um prédio, o crescimento da barba, etc. [...]. Então, ao contrário, ver mais lentamente transformações muito rápidas que nossos olhos não percebem. [...] inverter a ordem de um fenômeno. [...] reproduzir o movimento de estrelas e as mudanças que acontecem em suas superfícies, como as fases da lua, os raios do sol. (DESLANDES in TOSI, 2005, p. 31)
\end{abstract}

Nesse excerto, percebe-se que a novidade se aplica a praticamente todos os campos das ciências naturais e humanas. A relação arte-ciência já se delineia na percepção dos editores da Sociedade Francesa de Fotografia, como atesta o trecho a seguir:

\begin{abstract}
Nada poderia ser mais curioso na física do que a combinação perfeita da estereoscopia, do fenaquitiscópio e da fotografia, que possibilitam reproduzir o fenômeno extraordinário de figuras se movendo. Uma arte que poderia render aos objetos uma aparência de esculturas móveis, um resultado maravilhoso que a ciência já teria criado. (TOSI, 2005, p. 31)
\end{abstract}

Do outro lado do Atlântico, o interesse por tudo o que cerca a invenção da fotografia traz consigo o senso de necessidade/oportunidade. O físico, poeta, médico e entusiasta da fotografia Oliver Wendell Holmes estudou séries de fotografias estereoscópicas de pessoas caminhando pelas ruas de Londres e Paris para entender como aconteciam os movimentos de caminhada. Sua intenção era fabricar próteses para os soldados que tiveram membros mutilados durante a Guerra Civil americana.

\footnotetext{
${ }^{7}$ Acredita-se que o físico e matemático Joseph Plateau, inventor do fenaquistiscópio, tenha perdido a visão ao observar a luz do sol para estudar o fenômeno da persistência da imagem na retina.
} 
Antes de haver um dispositivo padrão com todas as questões técnicas aprimoradas, já se havia disseminado a multiplicidade de propósitos a que serviria a fotografia e, por extensão, o cinema. A possibilidade da reprodução em papel, ou da projeção em lugares amplos, fizeram com que a versatilidade do novo meio o tornasse adequado aos mais diversos usos. Isso valia especialmente no campo da arte, em que já se previa ser a fotografia um ramo particular do figuracionismo. Sobre isso, podemos citar o célebre texto de André Bazin "Ontologia da imagem fotográfica":

\begin{abstract}
A fotografia vem a ser, pois, o acontecimento mais importante da história das artes plásticas. Ao mesmo tempo sua libertação e manifestação plena, a fotografia permitiu à pintura ocidental desembaraçar-se definitivamente da obsessão realista e reencontrar a sua autonomia estética. (BAZIN,1991, p. 25)
\end{abstract}

Em relação às ciências, o que a fotografia e o cinema proporcionaram foi um salto quântico, possibilitando todos os tipos de descobertas, em todos os campos do conhecimento, sobretudo com a conquista do instantâneo fotográfico, o registro em curtíssimo intervalo de tempo, por volta de 1860.

O cosmos, eterno objeto e tema da existência humana, pôde ter seus fenômenos registrados e melhor estudados, inicialmente pelo pioneiro astrônomo Pierre-Jules-César Janssen, que iniciou sua carreira ocupando-se do funcionamento dos olhos. Entusiasmado com a fotografia e ciente da passagem do planeta Vênus em frente ao sol em 1874, iniciou a concepção e a confecção de um equipamento capaz de registrar as várias fases do movimento em intervalos regulares de tempo, para conseguir estudar o fenômeno na sua evolução dinâmica, o que chamamos hoje de time-lapse. É sua a ideia de usar um mecanismo de relógio para mover a placa sensível e o obturador. $\mathrm{O}$ equipamento não era perfeito, e há controvérsias em relação ao intervalo entre uma tomada fotográfica e outra. O próprio Janssen afirma ter sido de setenta segundos. ${ }^{8}$

A ideia de Janssen de que o registro fotográfico seria o corpus de pesquisa deriva da percepção de que, ao dissociar o fenômeno em si do tempo em que ele ocorre, pode-se analisá-lo a posteriori como suporte material que vai além da memória do observador (figs. 12 e 13). Porque, até então, a apreciação ocular (auxiliada por lentes, telescópios ou microscópios) era o único recurso do pesquisador. A partir da fotografia,

\footnotetext{
${ }^{8} \mathrm{O}$ sistema construído pela equipe de Janssen era constituído dos seguintes elementos: motor, sistema ótico, obturador e material sensível.
} 
possibilitou-se ao cientista calcular com mais precisão e compartilhar informações para a apreciação da comunidade científica.

É relevante o fato de Janssen atentar para a necessidade de se obter as imagens em intervalos regulares de tempo, como algo crucial do método científico, o qual presume um planejamento e um objetivo claros, a fim de que se estabeleça o modo de se responder a determinada questão.
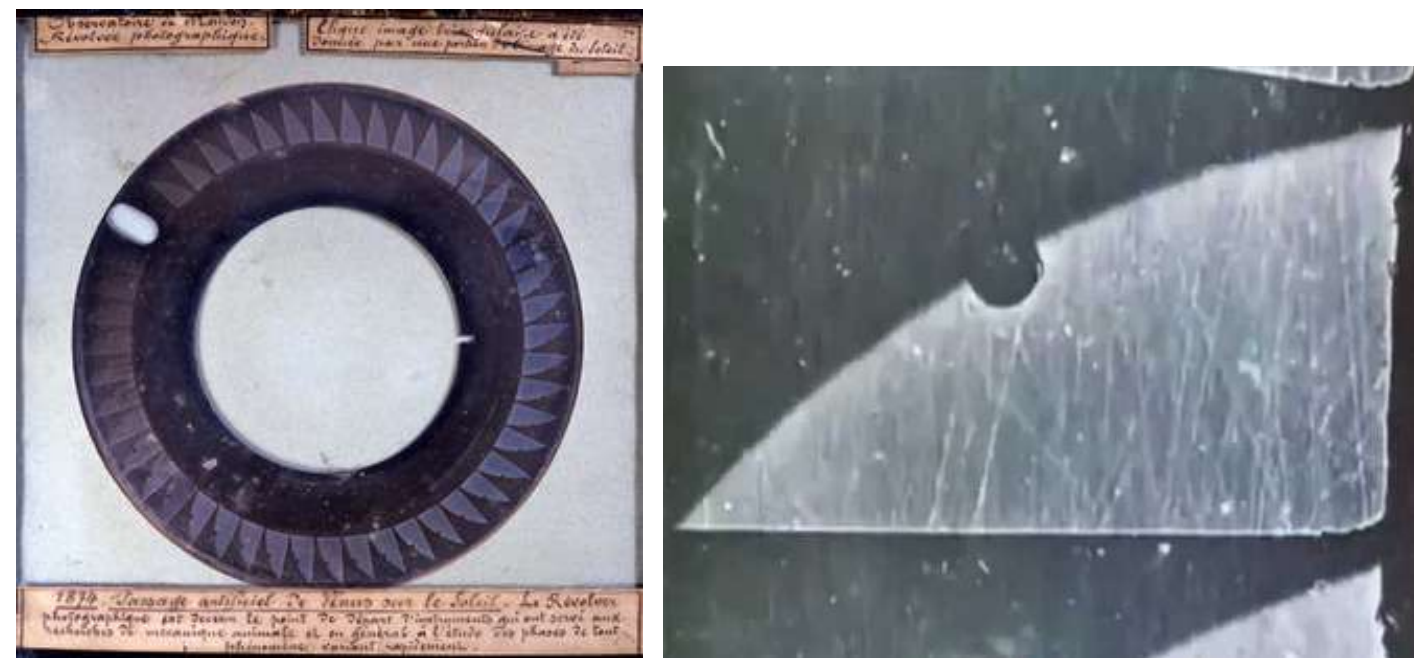

Figura 12 e 13: À esquerda, placa sensível do revólver fotográfico de Janssen (DAGUERREOTYPE, s.d.). À direita, impressão em papel mostra uma imagem isolada das etapas da passagem de Vênus pela coroa solar em 1874 (PASSAGE DE VENUS, s.d.).

Janssen buscava compreender se a coroa solar era um fenômeno visto na Terra causado pela refração da luz na atmosfera terrestre, ou se pertencia ao Sol. As imagens obtidas no Japão permitiram-lhe afirmar que a coroa solar, sim, pertence ao Sol, o que foi referendado mais tarde por outros cientistas (TOSI, 2005). Sua descoberta foi aclamada na Sociedade Científica Francesa e seu equipamento serviu de modelo para o desenvolvimento das futuras câmeras cinematográficas.

O aparato desenvolvido por Janssen, que fora mostrado na Académie des Sciences em 1873, um ano antes da passagem de Vênus em frente ao Sol, serviu de base para a expedição inglesa que desenvolveu um sistema semelhante para registrar o mesmo fenômeno, em outra estação de observação, para obter outro ponto de vista. Assim, declarou Janssen (apud TOSI, 2005, p. 38): “A expedição inglesa nos honrou adotando nosso instrumento, e obtiveram em suas estações algumas belas séries de imagens". 
Não nos passa despercebido o fato de Janssen se referir às imagens como "belas". Novamente lembramos Bachelard, que reitera o poder da experiência visual no campo da investigação científica. A respeito da beleza das imagens, entendemos que a qualidade exaltada por Janssen refere-se àquilo que delas se pode depreender, o quão úteis as imagens são para corroborar uma hipótese e eliminar ambiguidades.

$O$ interesse de Janssen era analisar cada instante da passagem de Vênus comparativamente, sem a intenção de ver o movimento reproduzido em projeção, mas ele tinha clara ideia das incontáveis propriedades em que seu mecanismo poderia ser aplicado. O revólver fotográfico

[...] permitiria estudar questões relativas ao movimento de diferentes espécies e comparar seus mecanismos em série de fotografias analisadas em um ciclo completo. [...] por exemplo o problema obscuro do voo dos pássaros, em que uma série de fotografias representaria os movimentos diferentes das asas. No presente momento, a dificuldade principal seria a inércia das nossas superfícies sensíveis, com respeito ao breve tempo de exposição que se requer para a obtenção dessas imagens. Mas a ciência vai eliminar essas dificuldades. (JANSSEN apud TOSI, 2005, p. 40)

Mesmo reconhecida a sua utilidade mecânica como busca da verdade e instrumento científico, a fotografia trouxe questionamentos em relação a seu valor, numa época em que já se sentia a oposição entre a fotografia científica - dita objetiva, sem permissão para retoques - e a artística - dita subjetiva, que autorizava tais interferências -, a exemplo da problemática da ilustração, que utilizava a mão humana. A miscelânea dessas tendências ainda causava escândalo na segunda metade do século XIX, pressupondo-se que o testemunho científico não admitia "correções" da mão humana. Esse desconforto foi percebido quando da publicação das séries de movimento de Eadweard Muybridge, um fotógrafo comercial, inventivo, que usava das técnicas de retoque tanto em seu trabalho artístico (retratos, paisagens) como em suas contribuições para a ciência.

Em junho de 1895, durante um congresso do Clube de Fotografia da França, alguns filmes dos irmãos Lumière foram exibidos, entre eles Sortie de l'usine lumière e L'Arroseur arrosé. Janssen foi o presidente do encontro e enalteceu as conquistas dos irmãos Lumière. Na ocasião, fez questão de diferenciar o que chamou de "fotografias animadas", os filmes de ficção, das "fotografias analíticas dos movimentos", ou o filme científico. 
O estudo do movimento inseriu-se no campo de interesse do mundo ocidental entre os séculos XIX e XX. Muybridge, inglês de personalidade extravagante (e controversa), cuja figura ficou inevitavelmente ligada às fotografias de cavalos trotando, fixou-se nos Estados Unidos em busca de fortuna e se atraiu pela fotografia. Sua história turbulenta já foi largamente explorada, e a parte que nos interessa é justamente a ponte que ele estabelece entre o campo das ciências, do desenvolvimento de tecnologia e das artes.

Muybridge já tinha inclinação por compreender mecanismos e motores, tendo desenhado uma máquina de lavar, entre outros inventos, quando teve contato com uma câmera fotográfica e pôs-se a explorar o equipamento em suas viagens pelos Estados Unidos (Fig. 14).

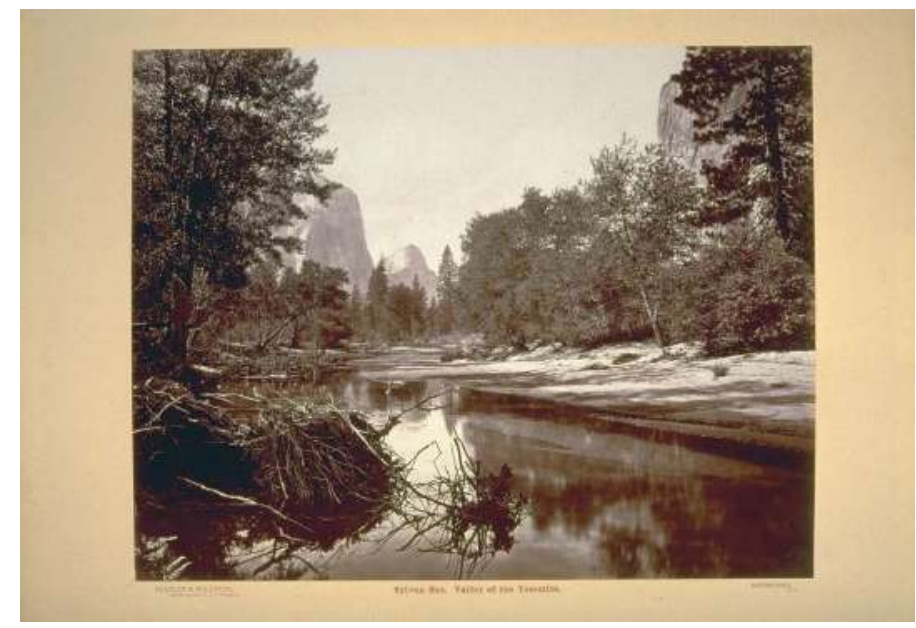

Figura 14: Em sua segunda expedição fotográfica ao Parque Nacional Yosemite, em 1872, Muybridge produziu uma série de paisagens pelas quais recebeu a International Golden Medal for Landscape na exposição de Viena de 1873. Muybridge já era aclamado como profissional inovador e talentoso. O sucesso de suas paisagens refletia um interesse nostálgico por "paisagens intocadas pelas mãos humanas" despertado pelo progresso dos centros urbanos (EADWEARD, s.d.).

Produziu séries de fotografias panorâmicas da cidade de São Francisco, de povoados longínquos e de lugares considerados exóticos, o que lhe trouxe certa fama e dinheiro.

Com essas experiências em fotografias de natureza, Muybridge juntou-se a missões do governo norte-americano para explorar algumas áreas pouco conhecidas do país ou outras recém-conquistadas, tornando-se o fotógrafo oficial. Chegou a documentar as últimas batalhas entre as forças armadas e os nativos Modoc. Nesse período, aproximou-se de Leland Stanford, industrial milionário e criador de cavalos, 
com quem estabeleceu uma longa parceria de mecenato na qual Stanford financiava os experimentos de Muybridge.

Proprietário de uma imensa faixa de terra, onde mais tarde fixou-se a Universidade Stanford, Stanford criava cavalos de corrida, esporte popular na época, e se preocupava em melhorar seu método de treinamento com base em princípios científicos. A essa altura, Etienne Jules-Marey já publicara alguns estudos de fisiologia animal e documentação do movimento, os quais, vistos por Stanford, levaram-no a encomendar a Muybridge uma sequência de fotografias que servissem de prova documental com valor científico de que, durante o trote, o cavalo ficaria por alguns instantes com as patas todas no ar (TOSI, 2005, p. 45).

O pedido foi inicialmente recusado por Muybridge, que não tinha certeza se conseguiria produzir uma sequência de fotografias que comprovassem a tese de Stanford, sobretudo pela falta de sensibilidade das placas fotográficas. Na verdade, muitos problemas metodológicos precisavam ser resolvidos para que o experimento funcionasse. Stanford colocou Muybridge em contato com técnicos da companhia de trem $^{9}$ (de sua propriedade), e juntos desenharam um sistema em que o trote do cavalo fechava um a um os circuitos elétricos que disparavam os obturadores das câmeras, dispostas em linha paralela ao trajeto do cavalo. Em junho de 1878 a imprensa toda cobria o evento mais esperado do ano, e acompanhava ao vivo o registro e a revelação do material exposto, pois uma operação com dezenas de homens foi planejada e ensaiada para o êxito da empreitada.

A série de fotografias estampou a capa da Scientific American de 19 de outubro de 1878 e causou espanto entre as comunidade científica e artística, pelo fato de algumas posições parecerem implausíveis e aparentemente absurdas. De todo modo, as séries apresentadas foram reconhecidas como valiosas referências no estudo da representação do movimento. Muybridge explorou comercialmente o experimento, vendendo impressões de suas imagens a quinze dólares cada. Também vendeu impressões em tiras de papel próprias para o zootrópio e fez várias apresentações de lanternas mágicas em que comparava suas imagens com representações artísticas de cavalos.

A colaboração entre Stanford e Muybridge rompeu-se com a desavença entre os dois após a publicação de The Horse in Motion, em 1882, com litografias feitas a partir

\footnotetext{
${ }^{9}$ Central Pacific Railway.
} 
das fotos de Muybridge. De um lado, Muybridge (que processou Stanford) se apresentou como o autor de todos os resultados, esquecendo-se de mencionar a parceria com Stanford; de outro, Stanford proclama-se, no prefácio, o mentor intelectual da experiência, e refere-se a Muybridge como o técnico empregado e contratado (BRAUN, 2013), em uma tentativa de desqualificar seu trabalho, relegando-o a uma categoria inferior. Desde o início da fotografia já havia entre fotógrafos a compreensão de que o novo meio não se prestava apenas à mera reprodução da realidade, como por exemplo, a prática dos pictorialistas da segunda metade do século XIX. Longe de ser apenas um técnico, Muybridge exemplificou a convergência da técnica com a expressão e levou adiante sua reivindicação como co-criador de The Horse in Motion, o que contribuiu para reforçar o status da fotografia como forma de arte.

As fotografias de Muybridge tornaram-se mundialmente populares. Após o contratempo com Stanford, Muybridge foi chamado pelo pintor Thomas Eakings, um dos mais importantes pintores americanos do século XIX, com quem já mantinha correspondência, para trabalhar na Universidade da Pensilvânia. Eakings era apaixonado por fotografia e vinha produzindo séries de fotografias de fases de movimento a partir de um dispositivo semelhante ao de Etienne Jules-Marey. Eakings utilizara as fotos de cavalos como referência em suas obras, e colocou Muybridge em contato com um novo ambiente criativo, em que os patrocinadores eram intelectuais e empreendedores, e ao mesmo tempo professores de várias áreas do conhecimento ligados à universidade e que tinham interesse profundo em pesquisa científica de ponta.

O financiamento do trabalho também contou com um sistema de subscrição, que incluiu as assinaturas de cientistas e de artistas como Alma-Tadema, Gerôme Meissonier, Auguste Rodin, Etiene Jules-Marey e Louis Pasteur. Assim, um amplo trabalho com animais e seres humanos em diversas situações deu origem à obra Animal Locomotion: the Muybridge Work at the University of Pennsylvania - the Method and the Result, de 1888.

É interessante que o Prefácio da obra já atenta para a importância da pesquisa científica no âmbito universitário, enfatizando os altos custos e a necessidade de vários esforços combinados:

A função de uma universidade não se limita à mera instrução dos estudantes. Pesquisas e investigações originais conduzidas por estudiosos experientes são uma parte importante do trabalho, que é em uma ampla visão o seu dever, deveriam estender auxílio a pesquisadores comprometidos em pesquisas 
muito custosas para ser concluídas [apenas] com recursos privados. (MUYBRIDGE, 1888, p. 5)

Com equipamento aperfeiçoado e melhoria do material fotossensível, o trabalho cobriu as áreas de anatomia e veterinária, trazendo também estudos de movimentos incomuns para a época, como a locomoção de pessoas paraplégicas ou o movimento de uma criança sem as pernas que sobe e desce de uma cadeira (TOSI, 2005. p. 73). Os modelos, sempre fotografados contra um fundo quadriculado e numerado, tiveram seus movimentos transcritos em gráficos e diagramas, e foram cuidadosamente analisados, retraçados e acompanhados por textos descritivos:

O membro é facilmente dividido em duas grandes partes - do quadril ao joelho e dos joelhos aos dedos dos pés. Os movimentos, em sua maior parte, são os movimentos para a frente dos membros traseiros, e para trás da parte do membro dianteiro além do cotovelo. (MUYBRIDGE, 1888, p. 44)

O excerto acima guarda semelhanças com um texto de Leonardo da Vinci (apud ARNHEIM, 1980, p. 148) que descreve os movimentos de partes específicas do corpo: "O pescoço tem quatro movimentos, dos quais o primeiro consiste em levantar o rosto, o segundo em abaixá-lo, o terceiro em virar para a direita ou para a esquerda, o quarto em inclinar a cabeça para a direita ou para a esquerda". Os desenhos de projeto contendo a disposição das câmeras, o detalhado sistema elétrico de disparo, as distâncias, enfim, todo o método de trabalho de Muybridge corroborou para o amadurecimento do pensamento científico do final do século XIX. Além disso, o modelo de armazenamento e disposição do material coletado, bem como a padronização da iluminação e dos fundos permitiram não apenas reproduzir o experimento, como gerar métricas confiáveis de estudo.

A exemplo do trabalho gráfico de Marey, as imagens esquemáticas dos membros em Animal Locomotion salientam aquilo que se pretende mostrar na evolução do movimento (figs. 15 a 17). "Uma vez que representar um objeto significa mostrar algumas de suas propriedades particulares, pode-se com frequência conseguir melhor a finalidade afastando-se marcadamente da aparência 'fotográfica'." (ARNHEIM, 1980, p. 148) Os detalhes da exatidão mecânica, em alguns casos, interessam menos do que algumas características essenciais. Nos exemplos a seguir (figs. 15 a 17), apaga-se ou rebaixa-se propositalmente a textura fotográfica para que o retoque dê conta de realçar 
apenas o objeto estudado: fotografia e desenho complementam-se. A interpretação transforma a fotografia em um diagrama.

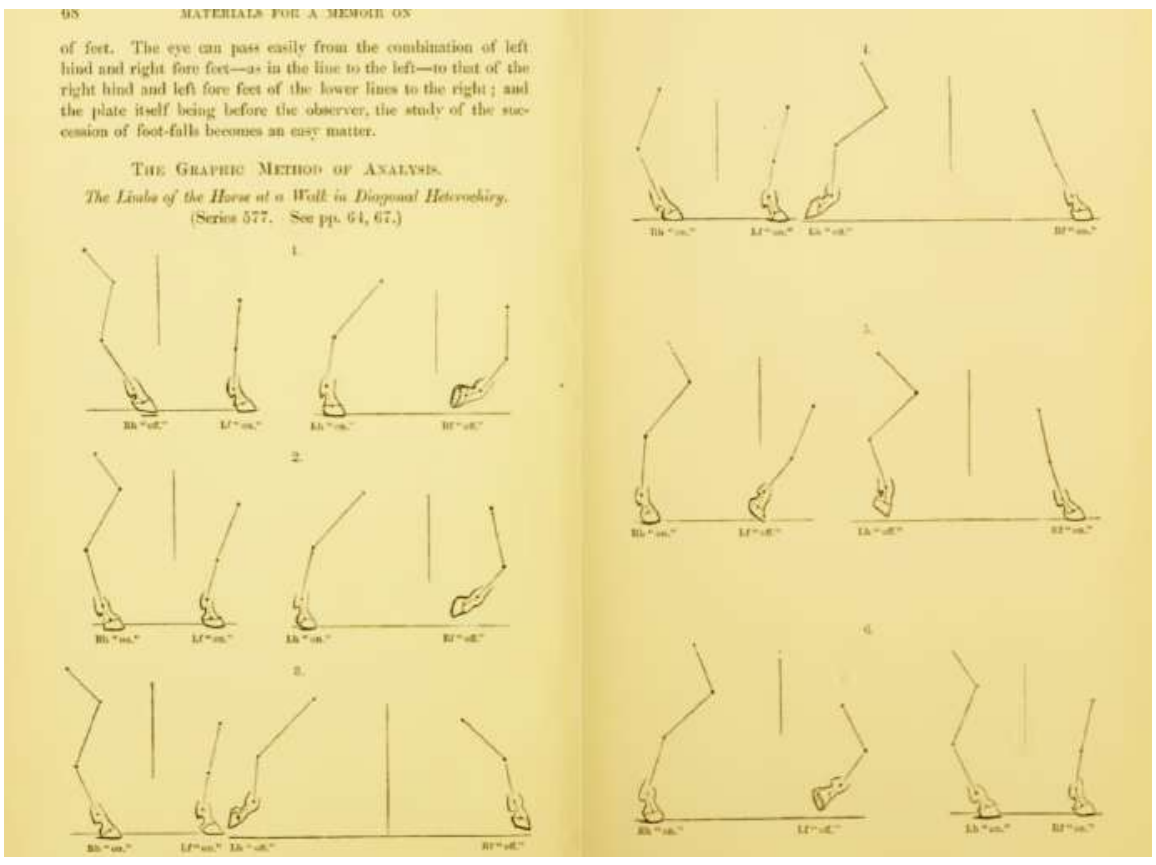

Figura 15: Animal Locomotion, 1887, p. 68-69. Nesta sequência, eliminaram-se os traços fotográficos, isolaram-se as pernas do lado direito e localizaram-se as articulações dos membros. Neste caso, o retoque da fotografia obedece a um sistema - o método gráfico - de tradução da imagem fotográfica (dita objetiva) para as linhas essenciais da dinâmica da marcha. O observador pode compreender a relação entre as patas dianteiras e traseiras.

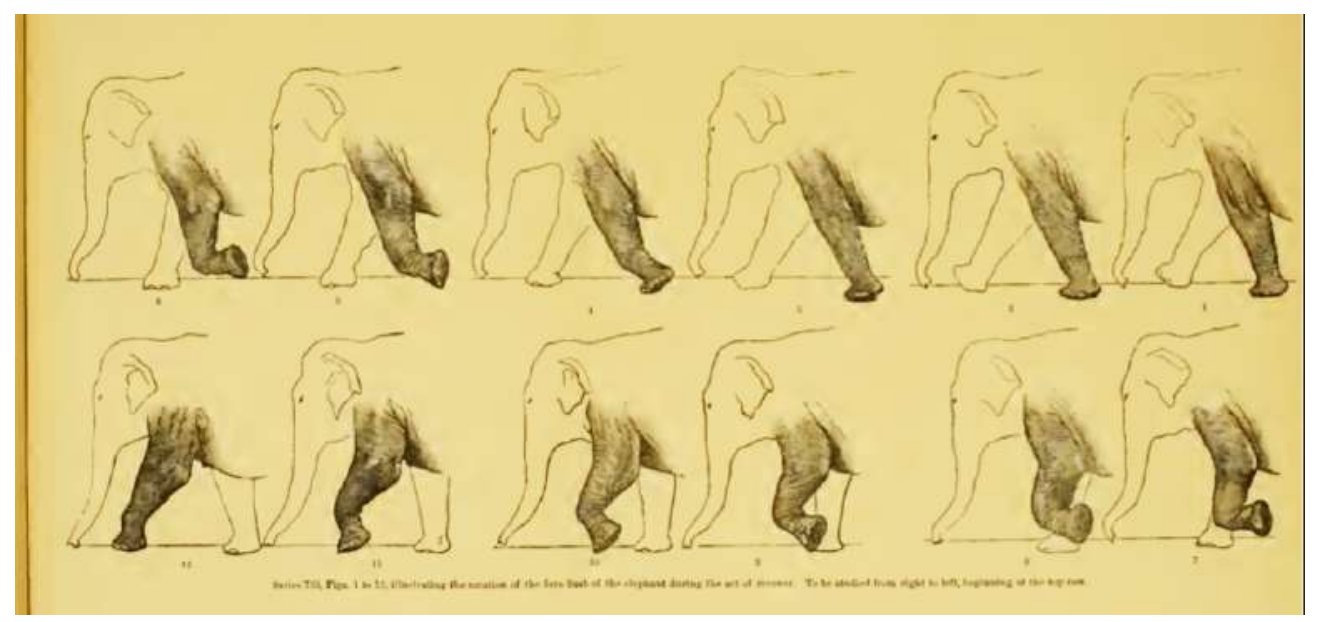

Figura 16: Animal Locomotion, 1887, p. 97. Aqui, novamente, as fotografias são reduzidas aos traços que sintetizam as etapas do movimento, uma evidente interferência da mão humana sobre o "pincel da natureza" (DASTON; GALISON, 2010, p. 133). O científico pode conter o artístico ou vice-versa? Ao beberem da matéria-prima natureza, ambos partem dos mesmos princípios e um pode alimentar o outro. $\mathrm{O}$ cinema de animação é um dos beneficiários diretos dessas pesquisas. 


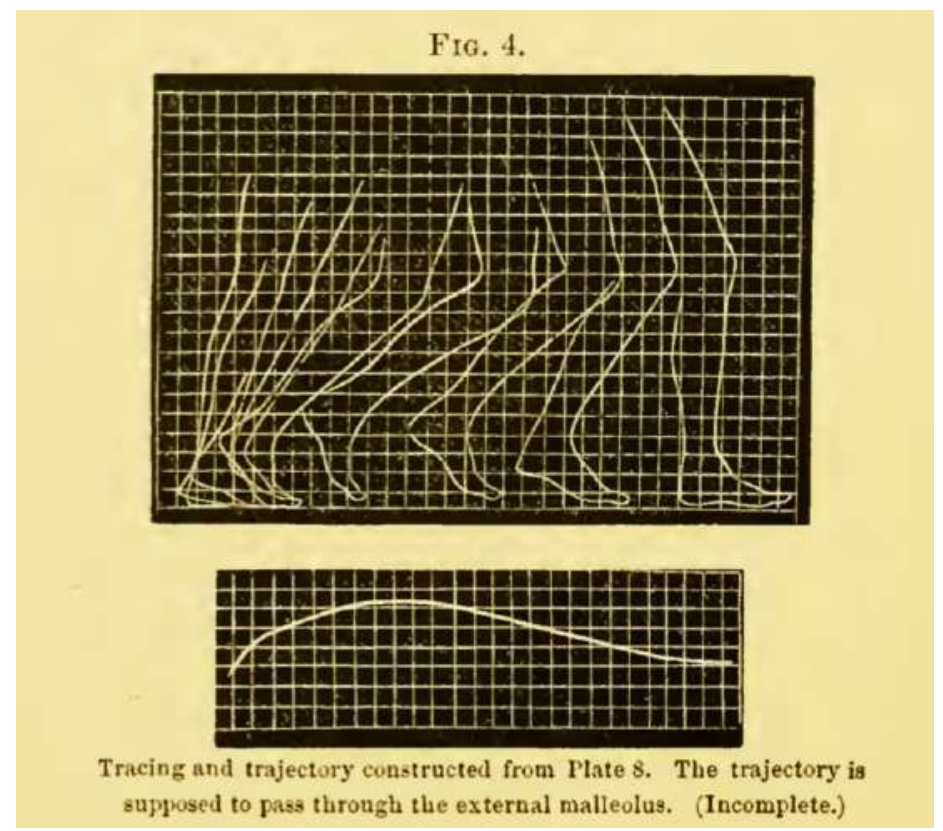

Figura 17: Animal Locomotion, 1887, p. 108. A linha ondular abaixo dos desenhos da perna mostram a trajetória do maléolo durante um passo. Reconhecemos a organicidade no movimento representada pela forma fluida desenhada no ar. Trata-se da geometrização do movimento a partir da interpretação/julgamento do resultado obtido.

Muybridge não tinha formação acadêmica e não era cientista. No entanto, o modo como conseguiu retratar os movimentos comparativamente, realçando elementos e provendo dados numéricos para estudos, resultou uma obra revolucionária, tanto do ponto de vista científico como artístico. Suas séries de movimentos com cães, gatos, camelos, elefantes, leões, gazelas, cangurus, aves e seres humanos em diversas atividades foram adquiridas por inúmeras universidades pelos Estados Unidos e Europa. ${ }^{10}$ Afinal, as fotografias dos animais e humanos em movimentos supriram os artistas de modelos em posições nas quais seria impossível conseguir posar.

A natureza espetacular das ações congeladas no tempo também exerciam fascínio - e ainda exercem - pelo fato de muitas delas serem captadas sob diferentes ângulos ao redor do modelo, algo que pode ser entendido como um antepassado do efeito bullet time, popularizado pelo filme Matrix (1999), em que a sequência fotográfica é obtida por câmeras posicionadas ao redor do objeto, conferindo-lhe (emulando) a tridimensionalidade temporal que a superfície do campo fotográfico é incapaz de representar.

\footnotetext{
${ }^{10}$ Precisando vender suas séries de fotos, Muybridge passou a divulgá-las em uma série de espetáculos pela Europa, chamada The Science of Animal Locomotion in its Relation to Design in Art.
} 
Muybridge retratava de modo distinto homens brancos ocidentais, mulheres, modelos não brancos, pessoas com limitações físicas e trabalhadores braçais. As mulheres, por exemplo, são retratadas com graça, em situações domésticas, maternais e, de um modo geral, mais sexualizadas do que as figuras masculinas.

Um aspecto que chama atenção é o fato de Muybridge nunca ter usado fundo quadriculado antropométrico com modelos humanos ocidentais, até iniciar a série com o modelo mestiço Ben Bailey. Bailey foi retratado à maneira de um estudo etnográfico, como um representante da miscigenação racial. Seus músculos e sua atitude reforçam o estereótipo do homem primitivo, forte e caçador. Ser retratado contra o fundo quadriculado rendeu às fotografias uma estética científica de credibilidade.

Human Figure in Motion e Animals in Motion foram relançados na década de 1950, obtendo enorme sucesso e trazendo de volta toda narrativa que cerca a turbulenta vida de Muybridge.
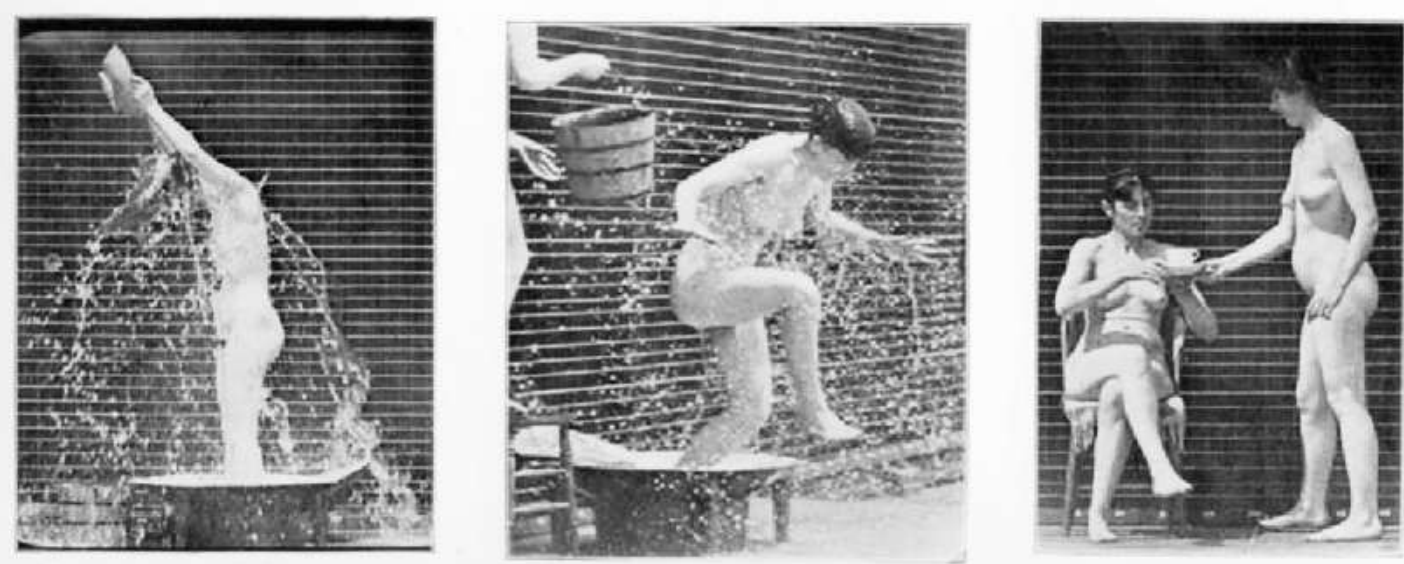

VARIOUS ACTS OF MOTION

Figura 18: Various acts of motion, sequência registrada por Muybridge (MUYBRIDGE, 1887, p. 214).

Além de Marey, o fotógrafo (também inventor) polonês-alemão Ottomar Anschültz foi um dos que se inspirou com o trabalho de Muybridge, concebendo uma câmera de alta qualidade e com obturador a 1/1000 de segundo. Isso foi bem útil nos trabalhos que realizou para as forças armadas, em estudos de balística e de treinamento de cavalos. Anschültz não era cientista de formação, mas fotógrafo profissional comprometido com a qualidade de imagem. Suas pesquisas e a engenhosidade de seus equipamentos atestam seu espírito científico-prático mais do que sua formação. Suas 
fotografias exploravam o universo selvagem, como flagrantes da vida natural e animais raros em seu habitat, e revelavam espontaneidade, como se o fotógrafo fosse invisível.



Figura 19: Série que mostra a decolagem de uma cegonha e seu pouso no ninho, de Anschültz (ANSCHÜLTZ, s.d.). As fotos de cegonhas foram tão bem recebidas, que Anschültz passou para a história como fotógrafo de cegonhas e como um pioneiro em fotografia animal em estado selvagem. Diferentemente de Marey, que produziu um estúdio para suas séries de imagens, Anschültz coleta suas imagens no habitat natural das espécies retratadas.

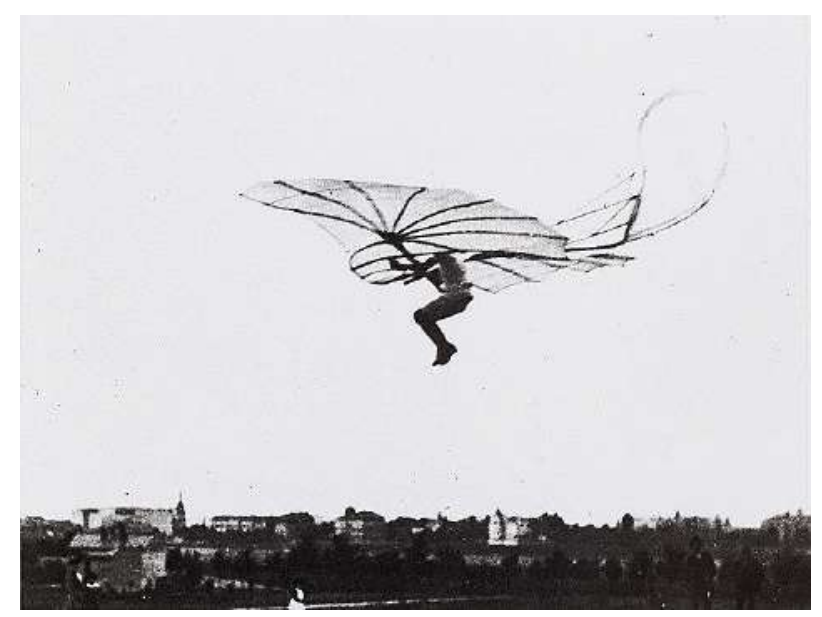

Figura 19: Registro de Otto Lilienthal, pioneiro em voo humano, feito por Anschültz. Lilenthal inspirou-se nas imagens de Anschültz e nas de Marey para conceber o primeiro planador. Anschültz registrou os voos de Lilienthal, em cuja propriedade encontrava-se um ninho de cegonhas (TOSI, 2005). 
Os documentários de animais para TV e cinema são herdeiros da estética contemplativa e testemunhal de Anschültz. A acuidade e a perfeição na captura de imagens fizeram dele uma referência no registro da vida animal.

Anschültz, cuja especialidade foram as fotografias instantâneas, também trabalhou com sequências de fotografias esportivas, tratando seus temas com rigor na composição do quadro, de modo a ter sempre a melhor nitidez do gesto. Especula-se que Thomas Edson, que estivera na Europa à época da Exposição de Paris de 1889, tenha usado algumas inovações de Anschültz em seu kinetoscópio.

Na Europa do século XIX, cientistas de vários países inspiravam-se uns nos outros, trocavam informações nos congressos, mostravam suas descobertas. Assim como Edson, outros cientistas-inventores-pesquisadores também aproveitaram melhorias alheias e as adequaram para suprir suas necessidades. É o caso de Jan Evangelista Purkyne, fisiologista tcheco que estudou o movimento do globo ocular. Estudioso da percepção visual, Purkyne também estudou a audição e a fala, além de aperfeiçoar o fenaquistoscópio de Plateau, que ele lançou no mercado como brinquedo científico chamado Phorolyt. Purkyne foi um dos que previu a possibilidade de aplicações das imagens mecânicas na indústria e também nas artes e na educação.

O uso de sequências fotográficas estendeu-se, desde Janssen, pelas mais variadas disciplinas. Albert Londe, médico do hospital Salpêtrière de Paris, foi contratado como médico-fotógrafo, capacitado para registrar em sequências de 1/10 segundos os mais variados eventos, sobretudo na área de psiquiatria. A informação do movimento era importante para observar as atitudes do paciente, mais do que as poses isoladas.

As fotografias mostravam uma faceta do ser humano feia e geralmente escondida, em que loucos ou doentes no meio de uma crise histérica ou de um ataque epilético eram expostos em seu aspecto mais repulsivo. As deformações do corpo e os experimentos com os enfermos eram registrados com o objetivo de extrair das imagens a compreensão das forças obscuras que agiam sobre o ser humano. As sequências fotográficas obedeciam a um método de captação conforme a biografia clínica e o sintoma do paciente. O olhar da objetiva captava com mais precisão que os olhos humanos os pesadelos e o universo caótico dos internos. A câmera facilitou o trabalho de inventariar as doenças nervosas, que passaram a ter suas características cientificamente catalogadas e nomeadas. A importância dessas imagens para o 
aprofundamento das doenças neurológicas e mentais é indiscutível, refletindo-se na melhoria nos tratamentos e no ensino.

No hospital Salpêtrière, a fotografia integrou-se à rotina diária, com um laboratório específico para estes registros nos anos de 1870. Os pacientes eram fotografados em seu estado normal e depois em seu estado de surto. Albert Londe desenvolveu um equipamento capaz de fotografar várias imagens por segundo para entender o gesto, a atitude.

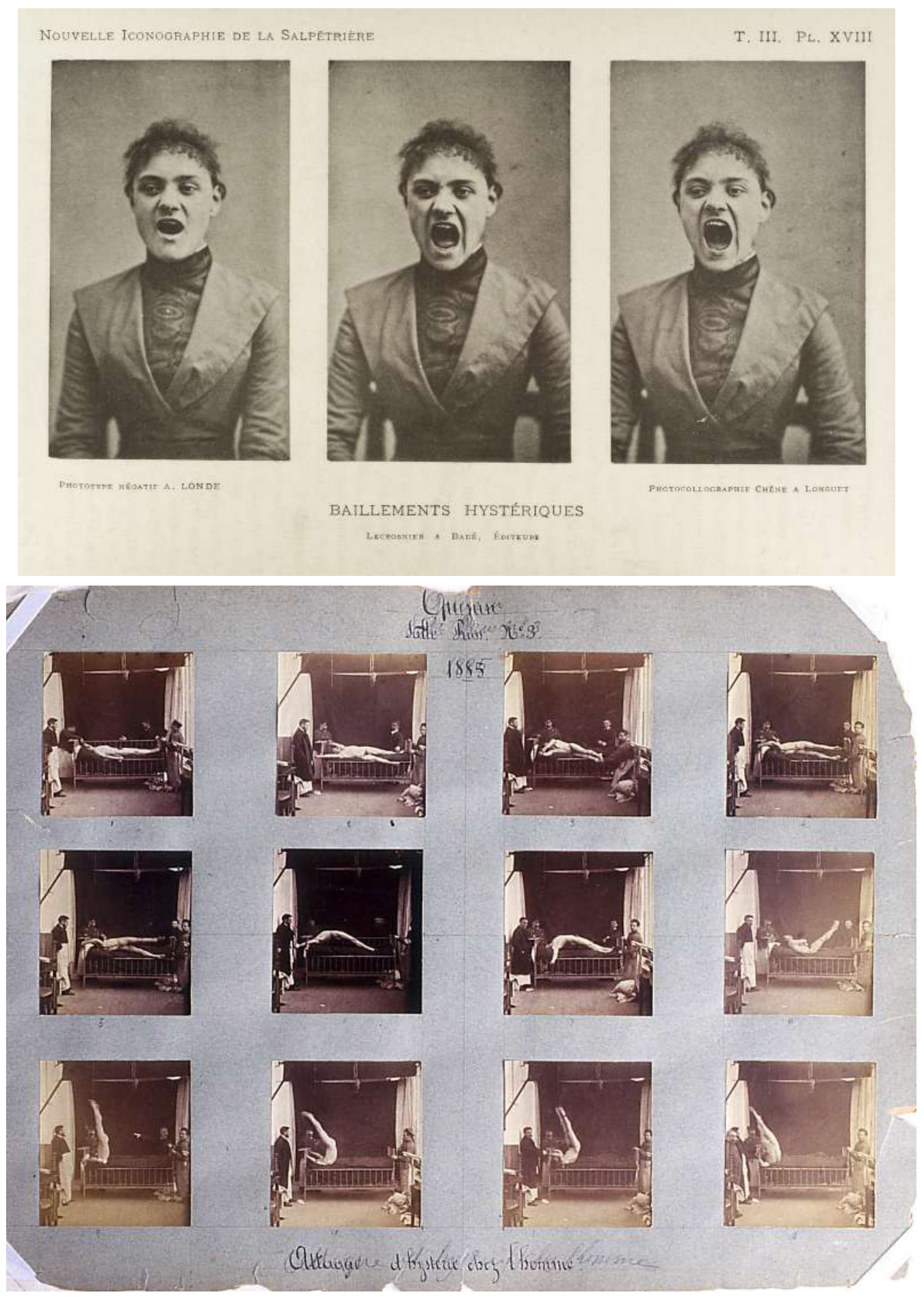



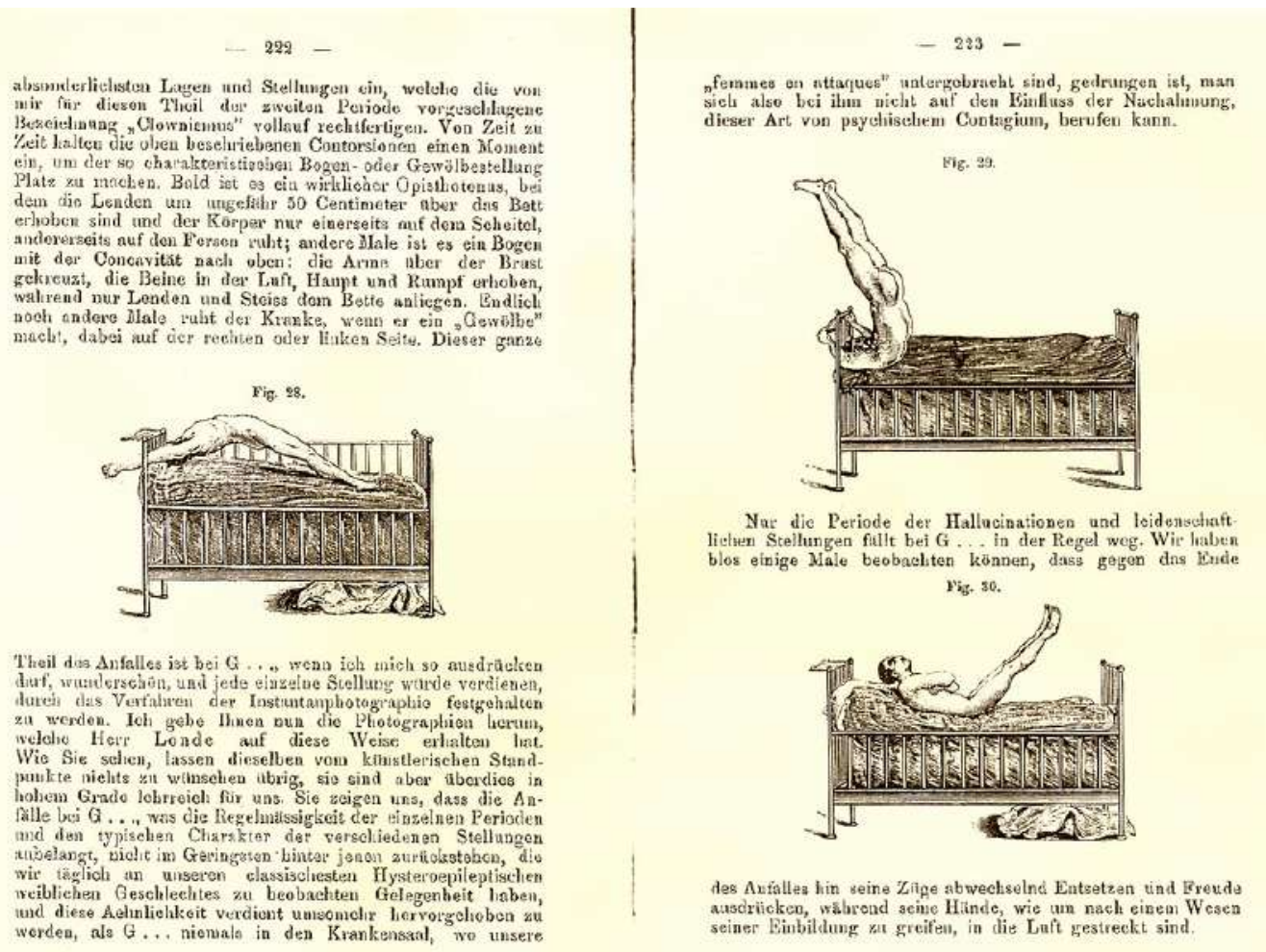

Figuras 21, 22 e 23: A primeira dessas três imagens é Series of three photos showing a hysterical yawning woman (SERIES OF THREE PHOTOS..., s.d.). Esta paciente boceja sete vezes por minuto, comportamento que sugere uma desordem neurológica dentro do espectro da histeria. Na segunda imagem, uma sequência de fotografias mostra o momento de uma crise histérica em um paciente do hospital de Salpêtrière (ALBERT LONDE, s.d.). Na terceira imagem, a mesma sequência foi convertida em ilustrações restritas ao essencial, o paciente em plena crise, objeto de estudo de Sigmund Freud,. Esta imagem integra o texto Neue Vorlesungen über die Krankheiten des Nervensystems, de Jean Marie Charcot e Sigmund Freud, de 1886 (CHARCOT; FREUD, 1886, p. 222-3).

Em termos da sistematização de um método para o uso da fotografia na pesquisa científica, a obra do fisiologista Etienne-Jules Marey é talvez o marco principal. Quando da publicação das séries dos cavalos na Scientific American em 1878, Marey impressionou-se com os resultados de Muybridge e pediu ao editor da revista que os colocasse em contato. $\mathrm{O}$ encontro foi efềmero e não resultou em parceria de pesquisa, mas as fotografias de Muybridge ampliaram sobremaneira as possibilidades investigativas de Marey (TOSI, 2005). Para ele, era um trabalho revolucionário, especialmente nas artes, por proporcionar aos artistas imagens de movimento em que um modelo jamais poderia posar, além de ser uma comprovação dos resultados obtidos com o método gráfico, anos antes.

À maneira de todos seus predecessores no registro da ciência, Marey era um estudioso obsessivo, que buscava resposta em todos os campos do conhecimento para 
suas investigações. Seu desejo era fazer engenharia, mas formou-se em medicina para agradar ao pai. Defendeu uma tese sobre o sistema circulatório e desenvolveu pequenos dispositivos para gravar as batidas do coração (TOSI, 2005, p. 84).

[...] transformou-se em um verdadeiro engenheiro das coisas vivas, introduzindo na fisiologia, através de mecanismos e dispositivos de precisão, toda uma metodologia de coleta e registro de dados que antes só era conhecida na física. Uma das medidas de sua genialidade está no fato de, praticamente um século depois, aparelhos de sua invenção continuarem em uso em cursos e pesquisas de fisiologia, no mundo inteiro. (GUIDI, 1991, p. 109)

Em 1881, com 50 anos, o eixo central da pesquisa acadêmica de Marey era a análise do movimento, e o problema que mais o atraía era o voo dos pássaros e, mais tarde, o humano. Na sua busca pela precisão, montou um laboratório de fisiologia experimental onde se dedicava a inventar sistemas de tradução/transcrição de informações tomadas de eventos reais para esquemas de visualização gráfica.

Assim, aperfeiçoou o equipamento criado pelo alemão Carl Friedrich Ludwig, que registrava o batimento arterial por meio de uma ponta seca a deslizar sobre a superfície de um papel coberto de fumaça, produzindo uma linha branca. Outro equipamento desenhado por ele permitiu estudar a caminhada humana, medir a duração, o espaço e a intensidade dos passos graças a um sistema pneumático. Muitos outros utensílios de registro de fenômenos foram idealizados e prototipados, na incessante busca pelo rigor metodológico que até então pertencia apenas às ciências físicas.

A precisão obtida com engenhosos equipamentos, levou Marey a publicar suas descobertas e comprovações, com repercussão além da esfera científica, invadindo o mundo artístico e chegando ao outro lado do Atlântico. Foi motivado pelo sucesso de Marey que Leland Stanford, ex-governador da Califórnia e criador de cavalos, contratou Eadweard Muybridge. Trabalhando em trajetos paralelos, mais ou menos na mesma época e com diferentes objetivos, Marey e Muybridge souberam reconhecer a genialidade um do outro.

Uma das preocupações de Marey era desenvolver um método que garantisse ao mesmo tempo a precisão das medidas e a repetição do experimento. Os mais variados instrumentos que desenvolveu permitiram-lhe realizar estudos comparativos e analíticos em movimentos humanos e animais, sempre fazendo referência às leis da física mecânica, o que deu origem à sua obra La Machine animale: locomotion terrestre et aérienne, de 1873. 
Quando um movimento muda a cada instante; quando assume a cada fração de segundo um diferente comportamento, ele desafia o olho que deseja seguilo e a mente que deseja analisá-lo, ele vai escapar do fisiologista? De modo algum! Ei-lo aqui registrado por uma máquina e fixado em papel. (ESCOUBE, 1931, p. 71)

Sem confiar completamente na visão humana, Marey criou o chamado "método gráfico", que consistia em tomar as informações de um movimento colocando cada pequena modificação em coordenadas espaço-temporais. Com isso, atacava dois obstáculos de uma só vez:

[...] a imperfeição dos nossos sentidos para descobrir a verdade e a insuficiência da linguagem para expressar e para transmitir aquilo que descobrimos. O objetivo do método gráfico é afastar esses obstáculos. [...] nas pesquisas delicadas, ele capta nuances que escapam aos outros meios de observação; se se trata de expor a marcha de um fenômeno, esse método traduz as fases com uma clareza que a linguagem verbal não possui. (MAREY, 1878, p. 10)

Marey passou a estudar formas de gravar movimentos rápidos e trabalhou no aperfeiçoamento do revólver (ou fuzil) fotográfico de Janssen, de quem ele reconhece o pioneirismo, para garantir a definição das imagens mesmo com uma maior velocidade do obturador. Criou, então, uma metodologia de registro em que era necessária a escuridão absoluta do ambiente onde as imagens fossem captadas em longa exposição (Fig. 24).

A ideia era que as diversas fases do movimento fossem registradas, em uma mesma placa fixa. Portanto, as imagens ficavam necessariamente sobrepostas. Para destacar o deslocamento dos membros, Marey vestiu o modelo com um traje preto e colou tiras de metal nas posições dos membros superiores, inferiores e na cabeça. $\mathrm{O}$ casamento do método gráfico com o fuzil fotográfico de Janssen, resultou em centenas de sequências de placas fotográficas com os registros dos mais variados movimentos humanos e animais.

Em 1884, quando lançou a segunda versão de La méthode graphique dans les sciences expérimentales, Marey comentou que o sucesso da cronofotografia seria útil para pesquisadores de várias áreas, não apenas para os fisiologistas. A melhoria no foco, a definição da imagem e o tempo do obturador foram conquistas que levaram seu emprego a muitas áreas do conhecimento. As pesquisas feitas repetidas vezes permitiram comparar padrões, identificar constâncias e analisar fases do movimento que a observação a olho nu não permitiria. 


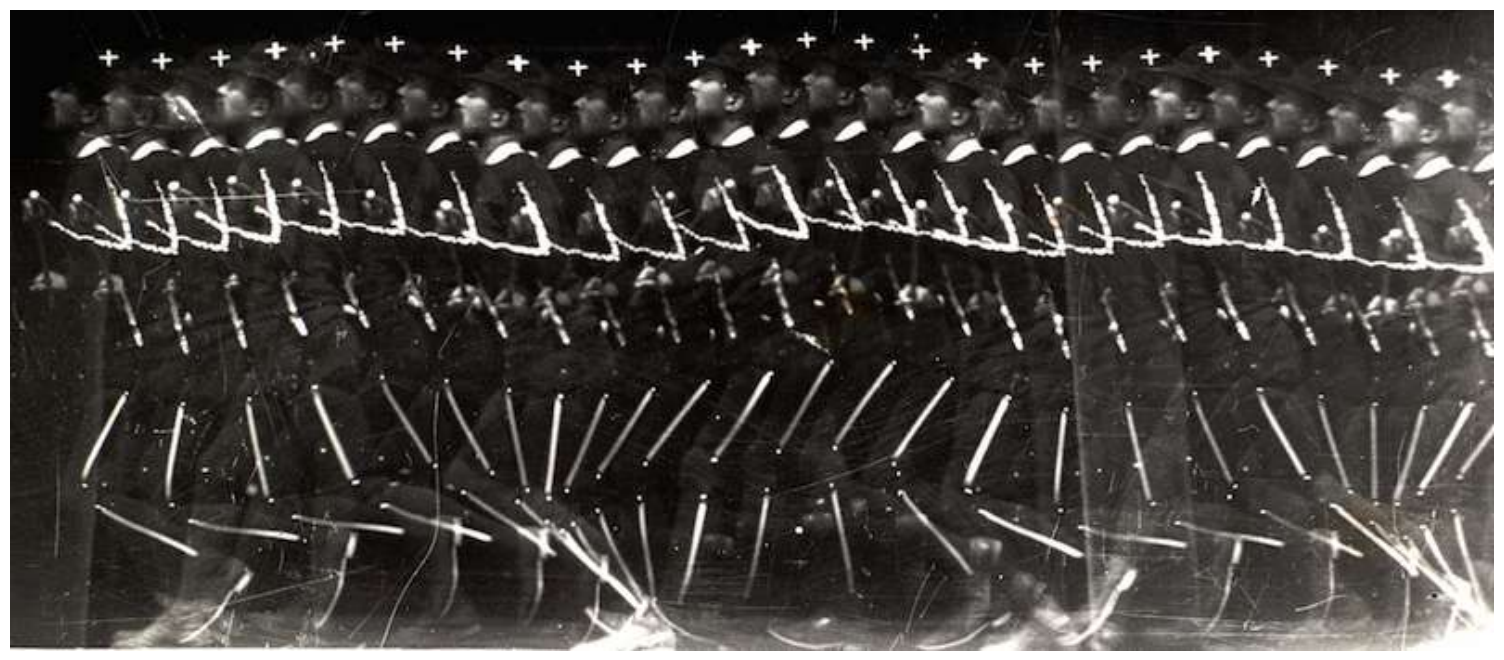

Figura 24: Domador de leões correndo (1886), cronofotografia executada a vinte exposições por segundo em uma mesma placa sensível (FERNANDES, 2017). O resultado deste registro é semelhante à interferência gráfica de Muybridge nas fotografias do passo. Marey criou um procedimento no qual vestia o modelo com roupa preta, contra o fundo preto, e colava em seus membros uma fita prateada, que refletia a luz incidente e imprimia na placa sensível, destacando o movimento cíclico do trote.

Os avanços tecnológicos de Marey sempre foram consequência das questões que ele se colocava, relacionadas ao seu interesse genuíno e central, o movimento. Ele sistematizava algumas dessas questões da seguinte maneira: qual a frequência do movimento das asas dos insetos? Quais as diferentes posições que as asas ocupam durante sua revolução completa? Como se desenvolve a força motriz que sustenta e transporta o corpo do animal? Por que a fixação de Marey pelo movimento? Para ele, "o movimento é o ato mais importante, no qual todas as funções prestam assistência para que ele se realize" (MAREY, 1868, p. 6).

Assim que terminou seu estudo sobre o voo dos pássaros, Marey já imaginava a aplicação do método sobre o movimento para todo tipo de animal, inclusive répteis, anfíbios etc.

Ele levantava novos problemas em relação à locomoção de quadrúpedes: estudar a corrida do cachorro em relação a de outros animais, começando com cavalos, o que lhe permitiria compreender profundamente e estabelecer analogias entre suas características anatômicas e funções fisiológicas. (TOSI, 2005, p. 110)

Em 1889, durante a Exposição Universal de Paris, Thomas Edison apresentou vários de seus inventos, em geral elétricos, com a intenção de vender produtos e patentes. Marey mostrou-lhe seu aparelho de cronofotografia, e Edison imediatamente vislumbrou uma nova possibilidade para o equipamento: produzir imagens divertidas 
que o público pagasse para assistir em seus equipamentos. Em 1894, quando lançou seu kinetoscópio, fez referência a Muybridge e Marey como suas inspirações para esta máquina.

Em 1890, Marey desenvolveu melhorias na cronofotografia e expediu uma patente, o que não era comum em sua prática. O dispositivo era portátil e o material sensível era agora um filme transparente que servia de suporte para o nitrato de prata e que corria através de um sistema mecânico. Com este equipamento, Marey iniciou uma nova fase em suas experiências. $\mathrm{O}$ tema retratado não necessitava mais estar contra um fundo negro. Entre 1891 e 1893, ele providenciou várias melhorias no equipamento, permitindo o uso com filme ou com placa fixa, e aumentando para até cinquenta disparos por segundo.

Marey ainda adaptou o cronofotógrafo a um microscópio, registrou atividade de animais aquáticos, sempre produzindo e apresentando artigos para a Sociedade Francesa de Ciências. Um artigo interessante foi escrito a partir da sequência de fotos da queda de um gato (Fig. 25):

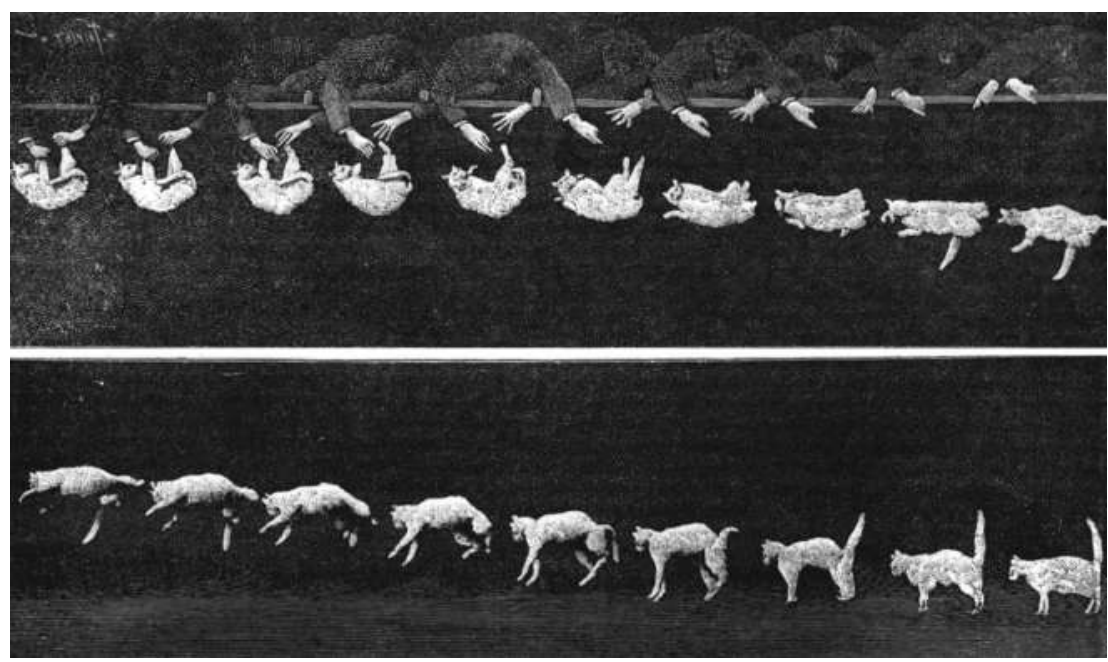

Figura 25: Sequência apresentada no artigo de Marey: Os movimentos que alguns animais executam para cair sobre seus pés quando eles precipitam de um lugar elevado, de 1894 (TOSI, 2005, P. 116).

Segundo um provérbio popular, o gato sempre cai de pé. [cientistas de] mecânica, entretanto, acreditavam que o gato não seria capaz de se virar sozinho no ar. [...] Agora, a experiência provou que o provérbio está certo... a $0,25 \mathrm{~m}$ do ponto em que ele caiu, ele já se virou no ar. Examinando a sucessão das fotos, podemos ver como isso acontece. A cronofotografia teve um papel importante na correção de um erro de formulação racional dos mecânicos. (MAREY apud TOSI, 2005, p. 115) 
Até aqui, ao comentar sinteticamente a vasta obra de Marey, percebemos que desdobramentos científicos de seu trabalho ampliaram a visão da ciência para um imenso número de temas. Paralelamente, sua pesquisa também trouxe avanços tecnológicos que encaminharam o desenvolvimento do dispositivo do cinema. Mesmo depois da primeira sessão de cinema dos irmãos Lumière (1895), Marey continuou desenvolvendo seu equipamento de cronofotografia, sem intenção de competir comercialmente com eles.

Seu interesse puramente científico levou-o a patentear poucos dos equipamentos que inventou. A maior parte foi presenteada à ciência em artigos que descreviam em detalhes como eram construídos. Há uma referência, em 1892, sobre possibilidade de vender câmeras de cronofotografia com o intuito de compensar parte de todo dinheiro dispendido nos anos anteriores. Segundo Tosi (2005), especula-se que o único exemplar vendido foi para Antoine Lumière, pai de Auguste e Louis. Há também registros de que os irmãos Lumière frequentavam o laboratório de Marey e conheciam as características dos equipamentos. Por outro lado, a fábrica de Lumière proveu durante muitos anos o laboratório de Marey com material fotossensível em reconhecimento a sua relação de longa data.

A ausência de interesse de Marey pela reconstrução/projeção das imagens, é ilustrado por esta passagem: “A projeção animada, que captura tanto o interesse do público, não oferece muitas vantagens do ponto de vista científico: ela não provê nada que a observação ocular não possa captar”. Entretanto, Marey chegou a usar o zootrópio como instrumento para conferir alguns de seus experimentos: ele montou as fotografias em sequência no equipamento giratório e verificou a fluidez do movimento. É notável o modo como Marey organizava o extenso material, em diagramação que valoriza e sublinha aquilo que deseja tornar claro.

Exaurindo as possibilidades de estudo de movimento animal e humano, Marey produziu também dezenas de fotografias nos campos da balística, da dinâmica de fluidos (Fig. 26), entre outros temas, os quais, traduzindo perfeitamente o espírito da época, integraram os fundamentos da metodologia e da ciência moderna. "Se eu fui capaz de voar, é porque eu li O Voo dos pássaros, o famoso livro de Marey” (Fig. 27), disse Wilbur Wright em sua homenagem a Marey no primeiro salão da aeronáutica em 1912, em Berlim.

Convencido de que seus inventos também seriam úteis no campo das artes, Marey fez vários comentários a esse respeito, realizando uma pequena pesquisa em 
torno da representação da figura do cavalo. Em suas observações, tanto a fotografia como a cronofotografia eram importantes para o artista retratar com o máximo de semelhança. Em Le Mouvement, há várias passagens, dentre as quais, destacamos:

\footnotetext{
Locomoção do cavalo do ponto de vista fisiológico - arte e ciência dão as mãos em busca da verdade. Os mesmos métodos servem igualmente para determinar as várias atitudes do cavalo que o artista deve representar, seguindo as fases do movimento sob o aspecto fisiológico e mecânico. (MAREY, 1894, p. 200)
}

Aqui, vale contrapor esta colocação de Marey com a declaração de André Bazin (1991, p. 25) em seu artigo "Ontologia da imagem fotográfica", em que conclui que a fotografia foi o "acontecimento mais importante da história das artes plásticas", porque "permitiu à pintura ocidental desembaraçar-se definitivamente da obsessão realista e reencontrar a sua autonomia estética". Marey e Bazin defendem a utilidade da fotografia para as artes, mas cada qual mira para uma tendência estilística. Marey, praticamente contemporâneo do invento, participante ativo e construtor da nova maneira de reter o mundo, expôs seu "encantamento" com a realidade objetiva do ponto de vista da descoberta das formas reveladas e congeladas. Bazin está em outra perspectiva: a de quem observa a preponderância da cor sobre a forma, a possibilidade da abstração e a apropriação artística das imagens científicas.

A preocupação de Marey com a representação da realidade encaixa-se, portanto, com a visão de mundo de sua época, a qual já estava em transformação. Do ponto de vista artístico, entretanto, Bazin aponta para uma camada mais profunda do impacto da fotografia nas artes se considerarmos que a representação não é outra coisa que a visão do artista sobre um objeto. Tal visão inclui distorções, interferências, recriações a partir da imagem real ou a partir de uma ideia abstrata. É o terreno do pensamento livre. Nesse sentido, Marey inspirou inúmeros artistas, mas não da maneira que imaginou.

Após praticamente esgotar as possibilidades do estudo do movimento nos seres vivos, incluindo peixes, Marey pesquisou uma forma de estudar o movimento do ar pela superfície dos corpos das aves. Antes de mais nada, era preciso tornar visível o ar. Para isso, desenvolveu uma "máquina de fumaça", precursora das que existem hoje em dia em laboratórios modernos (Fig. 26). Dentro de uma caixa de vidro pequenos tubos ejetavam fumaça na parte superior, a qual era aspirada para baixo, formando correntes de fumaça regulares em forma de filetes. Marey posicionava obstáculos à passagem da fumaça e verificava as deformações produzidas. 




Figura 26: Mouvements de l'air, estudos em aerodinâmica realizados com a máquina de fumaça, entre 1899 e 1901. Em 1963, à época da primeira exposição sobre Marey na cinemateca francesa, Henry Langlois descreveu sua obra como "nada é mais secreto, nada é mais lírico, nada é mais explosivo, nada é mais atual que o silêncio de seus negros e a leveza de seus brancos" (LANGLOIS apud MANNONI, 2005, p. 240, tradução nossa).

Entre 1899 e 1901, Marey realizou dezenas de séries, algumas das quais publicou no artigo "O movimento do ar estudado pela cronofotografia". Nele, apresenta essencialmente as fotografias obtidas, quase inexistindo textos explicativos. Marey expôs suas fotos e abriu o espectro dos estudos que puderam se beneficiar das imagens, desde a aviação, à ventilação e tudo que tenha a ver com o movimento do ar (MANNONI, 2005).

Não é exagero supor que Marey reconhecesse o fato de que as imagens falam por si só. Ele parece fascinado pelo espetáculo hipnotizante de suas fotos, que seduzem o olhar com uma sensualidade coreografada ao ritmo do sopro perene da fumaça. Cada uma das fotografias apresenta um motivo desenhado no ar, como um giz branco em tela negra.

A nova imagem poética - uma única imagem! - torna-se, assim, simplesmente, uma origem absoluta, uma origem da consciência. Nas horas de grandes descobertas, uma imagem poética pode ser a semente de um mundo, o germe de um universo imaginado diante do devaneio de um poeta (BACHELARD, 1968. p. 10)

Extraído de Poética do sonho, este trecho de Bachelard explica a economia de palavras de Marey diante da série de estudos com fumaça.

A poética involuntária das imagens de Marey impactou as artes plásticas e o cinema, sendo citada e revisitada com frequência desde o início dos anos 1900, mas 
principalmente pelas vanguardas das décadas de 1920 e 1930, sobretudo entre os surrealistas.

Marcel Duchamp, por exemplo, conjugou as tendências cubistass e futuristas com a estética da cronofotografia em sua tela $\mathrm{Nu}$ descendant un escalier, de 1912 (Fig. 27). Rompendo com a iconografia do academismo vigente, Duchamp afastou-se da aparência naturalista do nu: "Esta versão definitiva de $N u$ descendo uma escada [...] foi a convergência na minha mente de diversos interesses, entre eles o cinema, [...] com a separação das posições estáticas nas cronofotografias de Marey na França, d'Eakins e Muybridge na América" (CABANNE, 1995, p. 43). Para pintá-la, Duchamp estudou o movimento através da captura fotográfica semelhante ao processo de Marey e concentrou-se na representação da superposição das etapas sucessivas e no jogo da luz. A fragmentação e o geometrismo distanciam a figuração de um corpo humano naturalista, ainda que sejam reconhecíveis as proporções e articulações da composição. A obra causou um misto de entusiasmo e escândalo, mas consolidou-se como um marco da pintura moderna e da arte contemporânea.
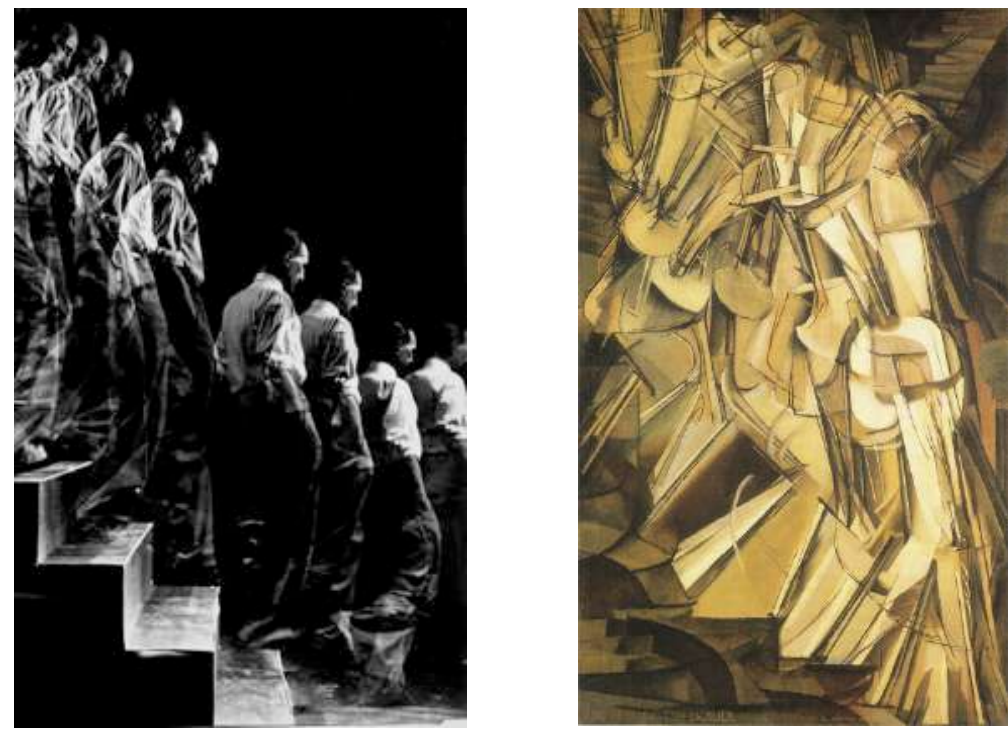

Figura 27: À esquerda, Marcel Duchamp em fotografia de Eliot Elifoson. À direita, $N u$ descendant un escalier, 1912 em que Duchamp representa as fases do movimento e busca imprimir na tela uma aparência de escultura em madeira através da paleta de cores de ocres e marrons.

Com o advento da fotografia, as artes plásticas começaram a se descolar do ideário e dos cânones da arte tradicional figutativa, iniciando um momento mais afeito ao risco das experimentações. A nova percepção de realidade que a fotografia engendra 
com a projeção mecânica, alavanca a expressão para um outro patamar de representação nas primeiras décadas do século XX.

Outro artista que exemplifica essa tendência, também marcado pela obra de Marey, foi Max Ernst, que se apropriou da imagem de um zootrópio de Matey para realizar Rêve d'une petite fille qui vulut entrer au carmel [Sonho da garotinha que queria entrar no convento], de 1930. (Figs. 28, 28a, 29 e 30).

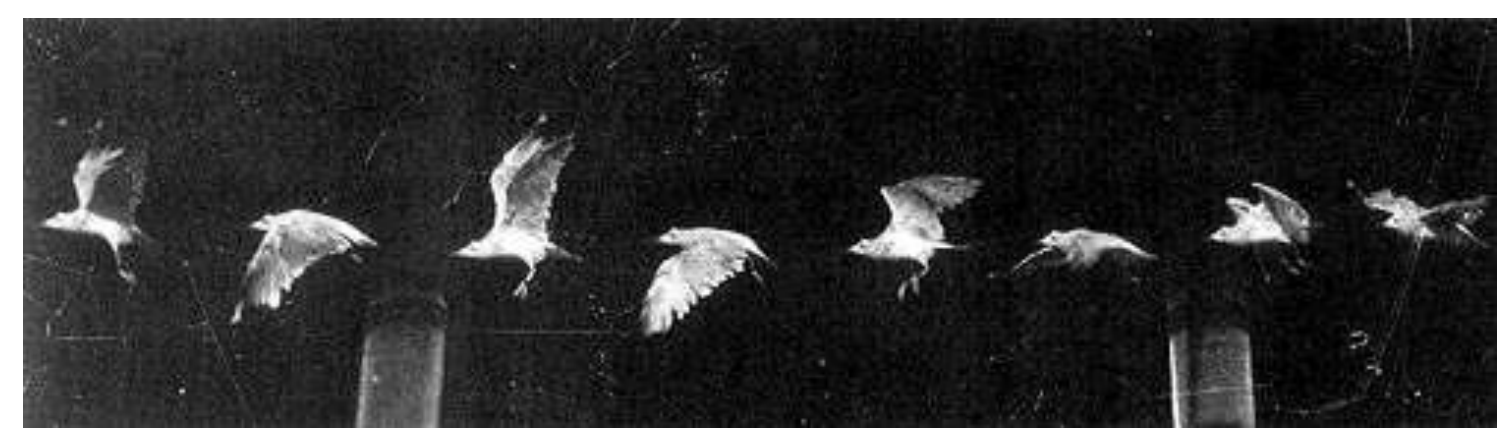

Figura 27: Fotografia original de Marey, Vol du Goéland, station physiologique, 1886 (ÉTINNE-JULES MAREY, s.d.).

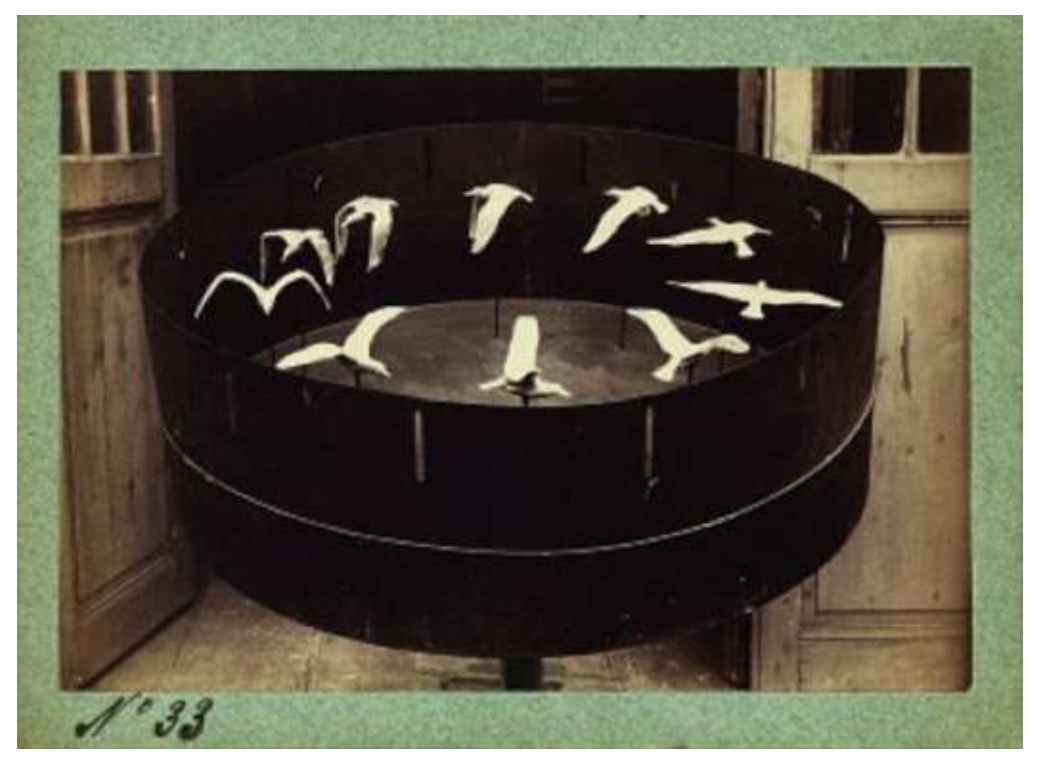

Figura 28: Zootropo no qual estão dispostas dez imagens de uma gaivota nas poses sucessivas do voo (MAREY, 1887). Esta pode ser entendida como a primeira geração de imagem após a fotografia original. 


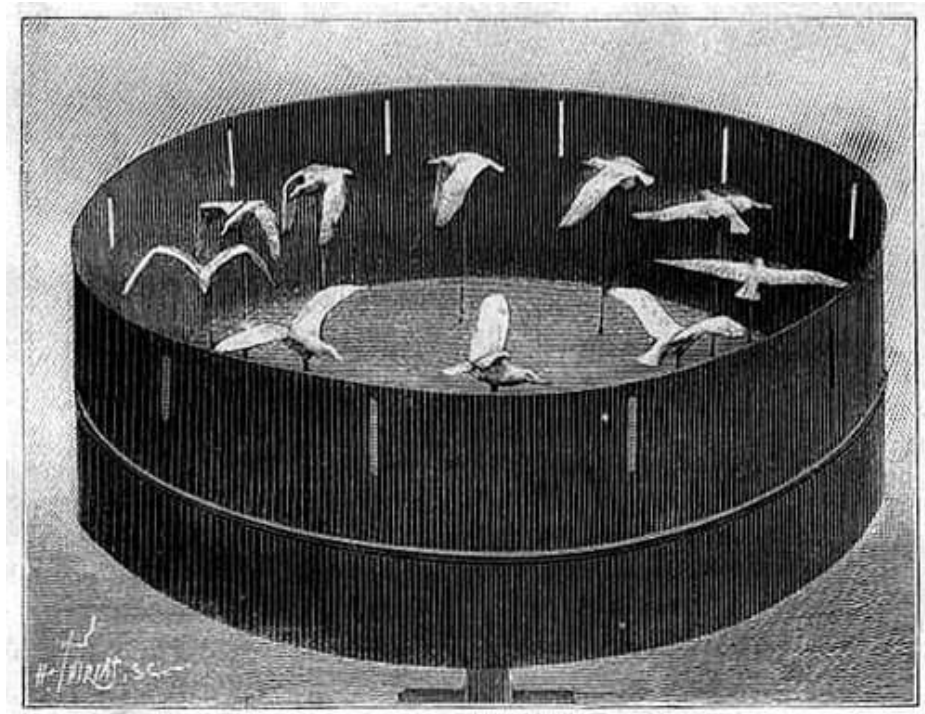

Fig. 9. - Zootrope dans lequel sont dispostes 10 images en reliet d'un goéland dans les attitudes successives du vol.

Figura 29: Litogravura de zootropo com as imagens da gaivota (ÉTIENNE-JULES MAREY, s.d.). Segunda geração de imagem após a fotografia original.

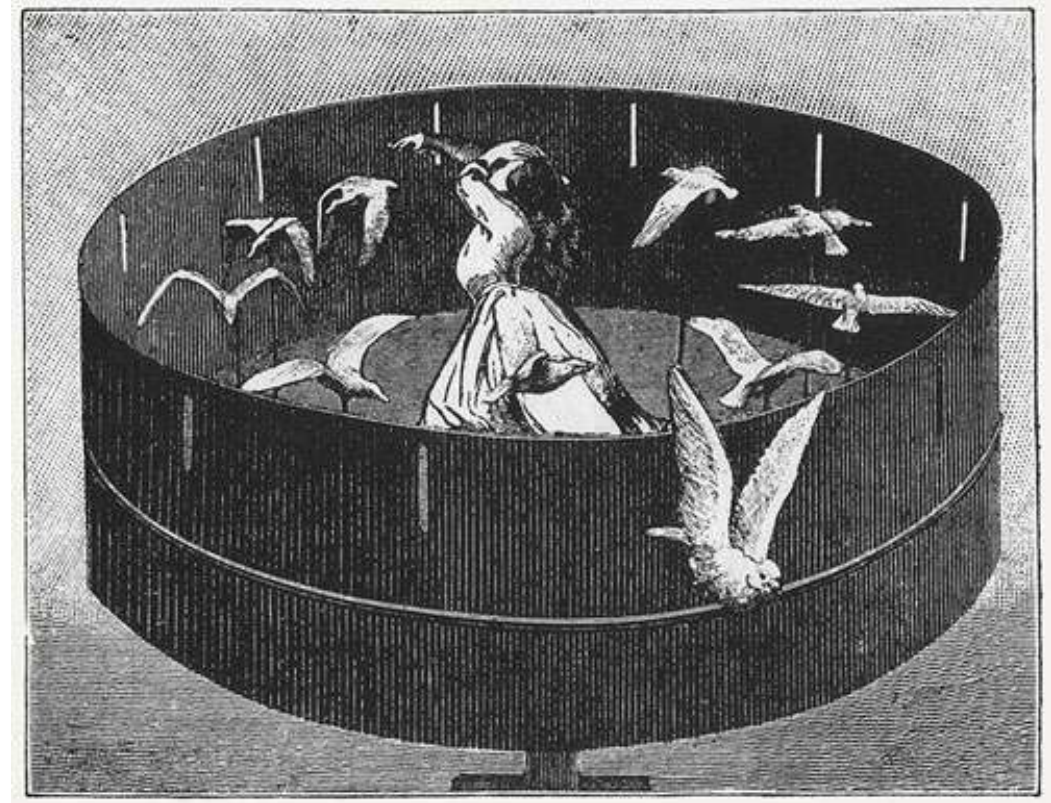

Figura 30: Rêve d'une petite fille qui vulut entrer au carmel, 1930 (MAX ERNST, 2011). Colagem de Max Ernst que representa a jovem que perdeu a virgindade no dia de sua primeira comunhão, e agora quer ir para o convento.

Nesta composição em colagem, Ernst apropria-se da imagem de Marey e the confere outro sentido. Ele parte da litogravura que retrata o zootrópio em esculturas, que já é por si a segunda geração de imagem após a sequência fotográfica original. Temos, 
portanto, a seguinte ordem: fotografia, esculturas em bronze e gesso, e litogravura a partir da qual Ernst criou sua narrativa. Sua composição aponta para um procedimento recorrente no século XX: a geração de uma obra a partir de outra como citação ou releitura. A arte pop pode ser entendida como exemplo disso, sendo amplamente discutida em função da sua reprodutibilidade em massa.

O congelamento dos movimentos para estudo trouxe a exata noção de sua qualidade gráfica, de seus padrões, de sua matemática. É uma linguagem nova que amplia e comenta a percepção da realidade, como uma ferramenta extra na pesquisa, na análise, na comunicação e na arte.

Ainda no campo do registro fotográfico, adentramos o universo nano no qual as dificuldades na criação e no julgamento das imagens/cenas sofisticaram-se. A captação mecânica (não apenas a fotográfica, mas a radiográfica, as câmaras de névoa, o espectro estrelar etc.) por si só não é garantia para a compreensão de um conhecimento, e isso resultou em desdobramentos. A interpretação e o julgamento, a partir de pressupostos teóricos, é o que determina, em muitos casos, o significado da imagem registrada de um fenômeno.

A produção de imagem das partículas subatômicas em câmara de névoa constituiu não apenas um desafio técnico, mas interpretativo, já que todo o procedimento metodológico era baseado em hipóteses. Em 1932, o físico Carl D. Anderson utilizou a técnica da câmara de névoa ${ }^{11}$ para capturar a fotografia da partícula pósitron (Fig. 31). A partir de uma hipótese teórica, construiu um equipamento capaz de congelar o movimento subatômico. Não basta uma imagem para entender o fenômeno registrado, mas uma coleção delas para se reconhecer algum padrão do evento. Aprender a identificar o inédito científico é uma questão de treinamento do olhar (DASTON; GALISON, 2010). Tais imagens, confundidas com abstrações, correspondem à unidade básica da matéria. Que elementos concretos tem o cientista para avaliar uma imagem como estas (figs. 31 e 32) e identificar/deduzir o que representam dentro de um quadro teórico ou de um conjunto de hipóteses?

\footnotetext{
${ }^{11}$ A câmara de névoa é uma caixa que contém vapor supersaturado. À medida que as partículas carregadas passam, ionizam o vapor, que se condensa para formar gotículas nos íons. Os rastros das partículas tornam-se visíveis como trilhas de gotículas, que podem ser fotografadas. Durante a primeira metade do século XX, experimentos que analisaram raios cósmicos passando através das câmaras de nuvens revelaram a existência de várias partículas fundamentais, incluindo o pósitron, o múon e as primeiras partículas estranhas.
} 


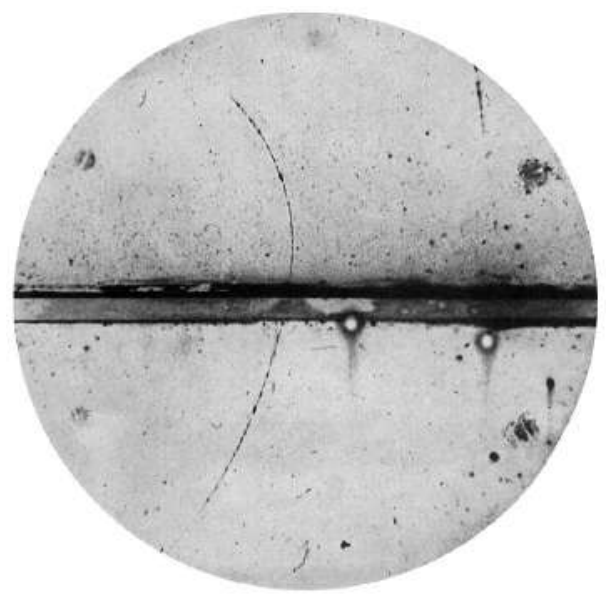

Figura 31: Primeira imagem obtida de um pósitron ${ }^{12}$ (elétron positivo), em 1932, a partir de uma câmara de névoa usada por Carl D. Anderson (CLOUD CHAMBER, s.d.). Trata-se do registro da passagem de raios cósmicos pela câmara de névoa e uma placa de chumbo. O trajeto do íon curva-se ao passar pelo campo magnético em uma direção que mostra que sua carga é positiva. A linha no centro da imagem é uma placa de chumbo de seis milímetros que separa as metades superior e inferior da câmara.

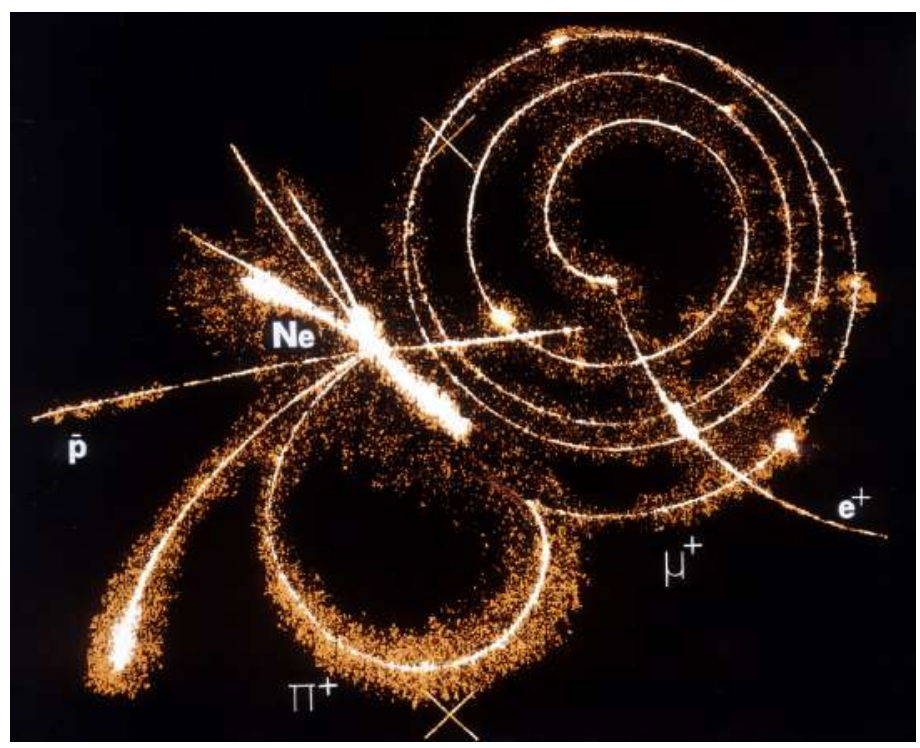

Figura 32: Fotografia de uma câmara de névoa preenchida de gás neon por onde a partícula elementar pion-múon-electron deixa seu rastro após o choque com um antiproton (HIGH ENERGY THOERY, s.d.). O antipróton entra pela parte de baixo da foto e aniquila com um próton. Sua energia se materializa como três fragmentos nucleares (os rastros mais grossos) e vários píons (rastros menos densos). Um píon positivo faz a curva para a direita no campo magnético da câmara antes de decair para múon; o múon faz uma espiral para cima antes de decair para pósitron. Os rastros deixados têm aspecto semelhante à da técnica fotográfica do Light Painting.

12 Para saber mais sobre o funcionamento da câmara de névoa, acesse: https://home.cern/news/news/experiments/seeing-invisible-event-displays-particle-physics 
A validade dessas imagens reside na objetividade e na reprodutibilidade do método empregado, não podendo ser desprezados fatores subjetivos como intuição e criatividade; sua interpretação conta necessariamente com fator subjetivo, a experiência pessoal do pesquisador no campo estudado. Será esta a mesma subjetividade de que o artista lança mão em seu processo de criação.

Esta atividade de julgar/interpretar o que se vê é uma mudança no paradigma científico em relação ao século XIX, quando a subjetividade era considerada um vício e a máquina "cega" poderia nos fornecer a impressão fria da realidade. No século XX, isso muda: como já vimos, os mecanismos para geração da imagem dependem do olhar e, muitas vezes, da modificação, da seleção, do contraste, enfim, é preciso alterá-la para evidenciar algo. Cabe tanto ao autor como ao leitor da imagem reconhecer o que vê e costurar relações. Veremos, no cinema, como a fabricação das imagem também obedece a uma subjetividade, que pode atuar em regimes distintos na sua relação com o públicoalvo. A subjetividade nas artes pode arremessar a criação em qualquer direção. Seu valor ou sua qualidade será atestada pelo tempo. No caso da ciência, parece haver um terreno mais sólido: por mais delirante que seja o caminho conduzido pela subjetividade, o resultado é sempre revisitado e testado.

A pesquisa apoiada em imagem ainda não conheceu seu limite, e o inesperado, quando surge, desafia e evoca novas questões, em um complexo terreno de incertezas, e donde novas experimentações exigirão novas premissas - aliança entre imaginação, dados obtidos, teorias testadas etc. Esse é o aspecto sensível da colaboração entre arte e a ciência e vice-versa, sendo a imaginação o elemento de base comum às duas esferas.

Até aqui percorremos as técnicas de registro nas ciências até mais ou menos o advento e a consolidação do dispositivo cinematográfico, quando a dimensão temporal transfigura a criação nas ciências e nas artes, mais ou menos à mesma época em que a física atômica transfigura o pensamento científico. 


\section{I.III Filme - Especificidades e contaminações}

Depois de acompanhar o percurso das ilustrações e fotografias no campo científico, refletiremos, nesta sessão de capítulo, as especificidades do cinema científico sob as óticas epistemológica, histórica e retórica. Essas óticas se entrelaçam ao longo dos textos, pois a perspectiva histórica não pode ser separada de uma visão de mundo, de uma filosofia, que por conseguinte, circunda aspectos epistemológicos do objeto estudado. Com um corpus heterogêneo, apontamos algumas obras e alguns produtores, e classificamos a filmografia escolhida em função dos tipos de uso do conhecimento em questão.

\section{Visão epistemológica}

Dentro do campo maior do cinema científico, o primeiro problema que se coloca é o das definições, etapas e nomenclaturas vistas na bibliografia, já que as fronteiras entre (1) filme de pesquisa, (2) filme de difusão científica, (3) filme pedagógico e (4) documentário científico costumam ser fluidas. Filmes de pesquisa são aqueles que trabalham com conhecimento em um estágio de produção e análise, que os cientistas usam para coletar dados, fazer cálculos e tirar medidas, ou para mostrar para seus pares o estágio da pesquisa. Os filmes de divulgação, o pedagógico e o documentário científico pertencem ao universo da educação e do aprendizado. Tratam de temas já consolidados, de conhecimentos já estabelecidos e trazem em sua estrutura procedimentos de facilitação por meio de imagens, analogias, simplificações, recursos de visualização como infográficos, animações, inserções, paralisações na imagem etc. Os limites entre essas definições é ambíguo, pois, no campo cinematográfico, tudo concorre para a adesão do espectador. São todas classificações conforme a função e o público do filme. Podemos reconhecer três polos: informação (inclui popular science films), educação (não formal) e pesquisa.

O cinema científico subsidiou pesquisas que brotavam de necessidades práticas e econômicas. Entender uma imagem científica requer um conhecimento prévio dos códigos teóricos e icônicos que lhe dão sentido. Não pretendo trabalhar segundo os fundamentos da semiótica, mas algumas de suas contribuições são bem-vindas nesta pesquisa. Segundo Charles Anderson Peirce (apud CALCAGNO-TRISTAN, 2005), uma imagem científica é um enunciado icônico cujos referentes (aquilo que elas buscam 
transformar) são corpos de conhecimento: ela concerne à interpretação científica do mundo, que é codificado na imagem. Os enunciados no discurso científico influenciam o modo como concebemos o mundo ao nosso redor, e boa parte dessa força discursiva vem das figuras de linguagem, sobretudo a metáfora, o que sugere a contaminação por um recurso frequente na atividade artística. Toda imagem científica tem simultaneamente um impacto afetivo e cognitivo. A tentativa de esconder os afetos, dimensão sensível, e enfatizar o rigor da informação científica, a objetividade e a dimensão cognitiva, é a prática preponderante.

As modalizações discursivas, as retóricas empregadas e o grau de estetização tornam fluidas as fronteiras. Ciência, informação e espetáculo compartilham o mesmo espaço, mostrando não apenas o real, mas o verossímil, por meio do agenciamento de elementos de cena (ambiente de laboratório, equipamentos tecnológicos, por exemplo), vocabulário (a linguagem usada na narração) e o objeto científico em questão. No seio do discurso científico, reside uma mensagem de ficção e uma mensagem estética, que criam uma retórica particular ao filme científico, em que a utilidade pedagógica e o prazer coabitam e estão sempre em movimento, interpenetrando-se.

O cinema científico é, antes de mais nada, uma construção cinematográfica e ele pode também ser a ciência e a pesquisa. Ele é uma argumentação baseada naquilo que nos é sensível nos modos inteligível e passional. São os primeiros passos da inteligência emocional sendo projetados, ao lançar mão de procedimentos estéticos e ficcionais juntamente a documentos e provas científicas. O filme científico não escapa do desejo nem da necessidade de convencer (CALCAGNO-TRISTANT, 2005, p. 57). Ele articula, por assim dizer, o olhar cognitivo e a retórica passional-afetiva sem a pretensão de ser ciência, mas de endossá-la e valorizá-la. Dentro do modo de operação ficcional, ele conta mais do que demonstra.

Com o approach cognitivista, a noção de representação passa para o centro da problemática, no sentido de que, sem representação, o cérebro não pode apreender o mundo, já que ele funcionaria segundo mecanismos de interrogação contínua em níveis sucessivos, de modo que todo ato perceptivo ou cognitivo traduz-se por um estado particular no nível neurobiológico, simbólico, semântico e representacional.

A relação entre conhecimento e interpretação dá-se no plano perceptivo da nossa existência. O conhecimento é resultado, pois, de uma interpretação permanente que emerge da capacidade de compreensão, a qual é enraizada na própria corporalidade biológica, mas é vivida nos domínios histórico, social e cultural. É essa capacidade 
interpretativa que dá sentido ao mundo. Nessa perspectiva, a educação estética é um conceito central na estratégia de persuasão, posto que a apreciação do objeto fílmico é atrelada ao conhecimento e ao sentimento.

As gradações de estetização e de ficcionalização na construção de uma retórica objetiva e emocional (eficaz no engajamento do espectador) constituem um trabalho de adequação entre conteúdo e forma em um permanente deslizamento entre os campos epistemológico e comunicacional. Instaura-se um processo de consolidação do espetáculo a partir do insólito, do não familiar: o estranhamento evoca o maravilhoso, ideia que nos remete a Viktor Chklóvsky, crítico literário russo, cujo nome é associado justamente ao conceito de estranhamento na arte, cujo objetivo seria proporcionar a experiência das coisas tal como as percebemos, não como as conhecemos. Para ele, o singular, o incomun são capazes de "libertar o espectador da letargia mental, realizando assim, a tão almejada comunicação estética" (VAZ, 2014, p. 45).

$\mathrm{Na}$ contaminação de linguagens, o contato entre os modos de enunciação científico e cinematográfico, por si só, é suficiente para transformação desses modos, pela simples presença do outro, em um processo que faz a ligação entre a imaginação e a inovação semântica (CALCAGNO-TRISTANT, 2005, p. 48). A demonstração argumentativa apoia-se em valores da ordem do rigor e do passional, donde o trabalho estético atua sobre a percepção, as sensações e o intelecto ao mesmo tempo. Disso resulta que procedimentos ficcionais e estéticos combinam-se com procedimentos tradicionais de provas científicas.

Um aspecto ficcional que pode surgir nesse hibridismo é o uso de uma narrativa, forma emprestada da literatura e bastante eficaz no processo de educação e persuasão. É o que acontece em diversos filmes que apelam para o romanceamento das situações flagradas pelas lentes, por exemplo, de Jean Painlevé, com a vida marinha, de Max Reichemann, com o desenvolvimento das flores, e de Okada Sozo, com as bactérias. A escolha da personagem do cientista - figura estilizada dele mesmo - confere à verdade científica um aspecto ficcional. Os índices de cientificidade no material que estudamos variam, portanto, em termos da vocação do enunciado discursivo. Alguns desses índices ou marcadores podem ser: o registro de um experimento, a narrativa sobre um fenômeno, o uso de terminologias específicas, a explicitação do registro temporal, os esquemas gráficos. Da combinação destes índices, saltam três grandes polos: discurso de pesquisador para pesquisador (comunicações em congressos, revistas), discurso 
didático (direcionado ao aprendizado), educação científica não formal (filmes de vulgarização, imprensa, museus).

No filme científico, o que se tem é a reprodução de um fenômeno observado e administrado como prova visível. O efeito de realidade transmitido pode mesmo ocorrer por um certo distanciamento da percepção natural desse fenômeno, por meio de um olhar original, em um processo de "intelectualização do real" (CALCAGNOTRISTANT, 2005, p. 77). Há, portanto, o objeto real da pesquisa e um modo de tratamento. É no modo de tratamento que reside o fator maior de subjetividade, donde a posição do cientista-cineasta define o modo de enunciação. O documentário científico, por exemplo, usa trechos do filme científico como documento de pesquisa em uma estratégia de formação e convencimento que lança mão da montagem e da construção de ritmo durante uma explicação. O resultado pode ser um encantamento e a difusão do interesse fora dos círculos científicos, algo que já acontecia desde o início do cinema, como é o caso dos filmes de ciência popular, que veremos logo mais.

$\mathrm{Na}$ interdisciplinaridade que acontece no domínio do conhecimento, o rigor e a objetividade são indispensáveis, já que a ciência navega entre a epistemologia, vista como teoria do conhecimento, e a comunicação. O discurso transversal é inerente a este tipo de produção.

Logo no início de sua história, o cinema mostrou-se um potente instrumento de difusão de conhecimento em larga escala, e muitas produções foram pensadas com esse intuito. A possibilidade de demonstrar por meio do tempo-espaço evoca um tipo de interpelação sincrética na sua essência, e permite outra forma de acesso ao conhecimento. O cinema tem o potencial de colaborar com a questão do ensino em larga escala.

\footnotetext{
No plano educativo, o cinema é o meio privilegiado de comunicar o pensamento visual entre seres humanos, de maneira suficientemente fiel e infinitamente mais direta, rápida e precisa do que através do pensamento verbal e da linguagem falada. (EPSTEIN apud UEBERSCHLAG, 2010, p. 106).
}

Essa ideia é partilhada por Jean Renoir no documentário Louis Lumière (1968), de Eric Rhomer. Renoir declara ter nascido praticamente junto com o cinema (1895) e que, já como estudante, com 6 ou 7 anos, assistia às projeções de comédias no cinema da escola, aos domingos: "Eu tinha a convicção de que estava diante de uma grande mudança na história da transmissão do pensamento humano" (RENOIR in LOUIS 
LUMIÈRE, 1968). Quando diz "pensamento" humano, Renoir abrange um aspecto bem mais amplo do que o meramente educativo ou o distrativo que o cinema podia circunscrever. Renoir anteviu uma nova relação homem-cultura que o cinema estava por forjar. De fato, no final do século XIX, o cinema incorporou-se à reforma pedagógica que visava levar instrução a uma imensa quantidade de estudantes, oferecendo-lhes uma formação coletiva e estandartizada.

O entendimento do cinema como auxiliar no processo de aprendizado não foi unanimidade. Max Nordau, médico húngaro autor de Degeneração (1893), apontava que o crescimento das cidades e o excesso de modernidade trariam consequências maléficas, tanto físicas como psíquicas, ao ser humano. Para ele, além de não contribuir com o desenvolvimento do homem, o cinema induziria o espectador a uma atitude passiva frente à intensificação forçada da realidade e à visão superficial dos fatos. Agente hipnótico, o cinema levaria à preguiça mental e subtrairia o espectador de suas faculdades críticas. Assim como o dr. Nordau, o dr. Paul Schenk também atentara para o problema da passividade provocada pelo excesso de estímulos, além dos danos à visão causados pela "flicagem" da projeção. Schenk fazia parte de um grupo chamado kinogegner, "inimigos do cinema", que relacionava os danos físicos a problemas psíquicos e morais causados pelo cinema (CURTIS, 2015, p. 130).

Em 1911, uma crítica mais abrangente foi proposta pelo professor de liceu Emile Brucker, que adotava a projeção de filmes em sala de aula, mas com restrições. Ele pensava na formação do espírito em paralelo ao desenvolvimento da inteligência. Para isso, o filme deveria ser mais do que uma ilustração em movimento: deveria ser um objeto de reflexão. Brucker foi um dos precursores do uso do filme na sala de aula, por entendê-lo um facilitador do acesso à mesma imagem de um fenômeno por toda uma turma de estudantes. No domínio das ciências naturais, ele considerava o cinema uma ferramenta indispensável. Não é fácil prover um grande número de estudantes de imagens microscópicas, por exemplo. Além das distorções espaciais, a manipulação temporal é um recurso visual surpreendente ao elucidar fenômenos lentos ou rápidos demais para a percepção humana. Assim, Brucker reivindica um cinema que estimule o estudante a dizer, a desenhar e a expressar de alguma forma aquilo que viu, criando hipóteses para uma pesquisa inventiva. O estudante observa, experimenta, cria e compreende. 
Ao final dos anos 1960, Jean Piaget retomou a crítica ao filme em sala de aula, opondo-se ao seu uso, por entender que as imagens prontas do filme limitavam a imaginação e impediam a criação de imagens mentais:

\begin{abstract}
A imagem, o filme, os processos audiovisuais dos quais toda pedagogia que deseja se dar a ilusão de ser moderna hoje são auxiliares preciosos como muletas [...]. Uma pedagogia baseada na imagem, mesmo enriquecida pelo aparente dinamismo do filme, permanece inadequada à formação do construtivismo. (PIAGET, 1969, p. 63)
\end{abstract}

Piaget queria evitar que o audiovisual servisse apenas para substituir o "verbalismo da palavra pelo verbalismo das imagens" (PIAGET, 1969, p. 63). Para ele, a questão central na educação seria: como engajar os alunos pela via da descoberta e renunciar a querer transmitir-lhe conhecimentos? Educar o espírito e não instruí-lo, eis o desafio. O filme de difusão isoladamente, sem um projeto crítico-pedagógico que o sustentasse, não atingiria seu objetivo. Aliada a esse questionamento está a ideia da imagem ser incapaz de se encarregar de um saber conceitualizado, e seu uso em excesso conduziria a um tipo de regressão da inteligência, a uma facilitação no exercício do pensar que pouco colabora no processo cognitivo.

Daí surge o conceito do filme heurístico: aquele que não fornece a resposta pronta, mas engaja o espectador em uma reflexão. Isso acontece quando a mudança no modo de percepção proporcionada pela experiência estética do cinema resulta em formulações mais profundas. O filme estende sua "vida" para além do momento de sua projeção em sala de aula; ele penetra na vida do espectador.

Percebe-se, portanto, que há uma categoria de filmes científicos que liberaram a imaginação jogando com o incerto, sem os comentários falados ou as explicações excessivas que, de um modo geral, "fecham" o sentido das imagens e impedem a interpretação do público. Assim é o filme heurístico, conceito conveniente a esta pesquisa, já que sua finalidade é arejar o espírito e fermentar aquilo que vai de algum momento florescer, desencadear uma reflexão autônoma por parte do espectador (UEBERSCHLAG, 2010, p. 108). Heurístico vem da palavra grega heurisko, "eu encontro" (ou "eu acho", "eu descubro"), e tem a mesma origem da palavra heureca ou eureca.

No filme heurístico, há um certo grau de elasticidade entre o significado e o significante, um grau de inexatidão em relação à verdade, o que constitui um elemento decisivo para o espírito investigativo do aluno, podendo levá-lo a aprender por si mesmo. A prioridade no heurístico é a formação do espírito, como preconizava Brucker. 
Nesse caso, a instabilidade transfere-se para a curiosidade, para a sede de compreender, resultando uma atividade psíquica e mental que se relaciona com a história pessoal de cada aluno.

Os processos de investigação científica, de aprendizado e de apreciação/fruição artística passam necessariamente pela observação e pela seleção. Há uma intersecção entre o conceito de filme heurístico com o pensamento de Erwin Panofsky em Significado nas artes visuais, quando ele enfatiza que "muita coisa está nos sentidos sem nunca penetrar na mente. Somos afetados por aquilo que permitimos que nos afete" (PANOFSKY, 1976, p. 25). De acordo com o crítico, após a observação, o caminho pelo qual o espectador apreende tanto o material científico quanto o artístico passa pela decodificação/interpretação, e em seguida pela classificação/ordenação de modo a dar sentido, a criar uma significação estética. Para ele, o não racional é integrado à apreensão cognitiva em regime simbiótico. Nas obras de arte, requer-se a experiência estética em que se realiza a unidade: ideia-forma-conteúdo. $\mathrm{Na}$ integração destes elementos, temos o que Panofsky chama de gozo estético. Também podemos falar em projeção emocional e sinestesia como fenômenos inerentes à experiência cinemática.

O filme heurístico é econômico em verbalismo, evita termos técnicos e trabalha as ideias de forma indutiva e não dedutiva. No lugar de descrever algo, mostra de perto, de vários ângulos, sendo o realizador um mediador, na tentativa de posicionar $\mathrm{o}$ estudante no lugar mesmo do cientista. A possibilidade de assistir juntos a um filme científico permite aos estudantes "compartilhar um momento de descoberta e de prazer em sala de aula" (UEBERSHLAG, 2010, p. 109). Essa emoção em grupo torna-se o motor do diálogo mais amplo sobre o fenômeno visto e sua interpretação.

\section{História e filosofia no cinema científico}

A discussão em torno do "nascimento" do cinema foi acirrada no final do século XIX e durante as primeiras décadas do século XX. As simplificações historiográficas resumiram o grande imbróglio da maternidade do invento a um "cabo de guerra" entre os irmãos Lumière e tudo o que já havia sido desenvolvido antes, especialmente, os inventos de Emile Reynaud e de Etiene-Jules Marey. Os periódicos especializados em cinema discutiam incansavelmente este assunto, de maneira que, em 1926, o periódico Le Nouvel Art Cinematographique comentou, nos trinta anos da arte cinematográfica, a disposição de uma placa comemorativa com os dizeres "aqui ocorreu a primeira 
projeção de fotografias animadas pelo cinematógrafo inventado pelos irmãos Lumière". No mesmo número, Maurice Noverre ${ }^{13}$ iniciou a polêmica, entendendo que algo só é inventado quando não existe nada antes (ANEXO VI).

Ele buscou justiça com um artigo extenso reivindicando que a primeira projeção creditava-se a Émile Reynaud. Desde 1877, seu praxinoscópio já projetava cenas animadas, em cores, com personagens e cenários e, a partir de 1892, projetava cenas de oito a quinze minutos. O próprio Reynaud, que passara mais de 25 anos estudando o assunto (quando Louis Lumière ainda era garoto), em 1880 admitiu que o movimento seria mais belo (exato) se houvesse fotografias no lugar de desenhos feitos a mão. Em 1888, Reynaud patenteou o praxinoscópio com imagens fotográficas, com várias cenas, compondo o Teatro Óptico. Noverre lembrava ainda a atenção de Reynaud para a necessidade de estabilidade das imagens, agradável aos olhos, para a qual ele projetou a banda perfurada no próprio filme, que patenteou em 1888.

Outro texto, de 1927, no mesmo Le Nouvel Art Cinématographique, sentencia: "Reynaud é o criador da projeção animada, Marey é o criador da cronofotografia, e os Lumières são os industriais que uniram as tecnologias de forma definitiva" (ANEXO VII). Os Lumière já tinham, portanto, todo um caminho aberto pelos antecessores, entre 1870 e 1890, cada qual acrecentando melhorias conforme a necessidade de pesquisa. Hoje compartilha-se uma visão de que o cinema é fruto de uma conjuntura complexa que envolve a ciência, as artes, o espetáculo, o urbanismo, enfim, tudo que estava em ebulição na segunda metade do século XIX.

$\mathrm{Na}$ apresentação de estreia dos irmãos Lumière, o astrônomo Janssen estava presente como mestre de cerimônia. Ele, para quem "a fotografia é a retina do cientista”, subdividiu o cinema científico e o cinema espetáculo e propôs a seguinte distinção sem emitir juízo de valor: photographie analytique des mouvements e photographie animée.

Mesmo com a autoridade de Janssen e de Marey, o cinema como ferramenta de pesquisa não acessou facilmente o domínio fechado da academia. De certa forma, era visto como algo passível de trucagens, não completamente confiável, e também falho no espírito demonstrativo (CALCAGNO-TRISTANT, 2005). Assim como as interferências artísticas nas ilustrações, a manipulação do tempo-espaço no cinema representava um problema quando o que estava em jogo era a verdade.

\footnotetext{
${ }^{13}$ Advogado ancião, membro da Association Profissionnellel de la Presse Cinematographique de Paris.
} 
É compreensível que nessa época houvesse de fato uma parcela de incredulidade em relação ao dispositivo cinematográfico na academia. Até o final do século XIX, praticantes de todo tipo de demonstração de curiosidades científicas apresentavam seus experimentos em forma de espetáculo, uma tradição que engajava a plateia por meio dos sentidos e apelava para um estado afetivo de maravilhamento. Esses espetáculos, chamados popular sciences (GAYCKEN, 2015, p. 4), originaram os filmes de ciência popular, ou popular science films, os quais guardavam afinidades com outro tipo de filme: o trickfilm, filme de efeitos de animação, ou seja, filmes do domínio ficcional.

Essa relação da ciência com o espetáculo foi bastante explorada no período de 1895 a 1913 por algumas companhias, destacando-se a Charles Urban Trading Company, a Pathé, a Gaumont e a Éclair. Nesse período, as temáticas de maior popularidade eram os filmes em microscopia, os time-lapses e imagens em alta velocidade, e as filmagens em raio-X, sempre relacionados com cenas domésticas ou de fenômenos que em geral passavam despercebidos. Essa produção se situava entre a ferramenta científica e a cultura popular. Entre 1904 e 1914, houve um conflito entre a crítica que elogiava o entusiasmo científico que esses filmes despertavam, e seus detratores, que viam esses filmes como uma produção de baixa cultura, sensacionalista.

\section{Rebelião científica}

Foi Henri Bergson quem trouxe o cinema para o centro do debate sobre método científico, de forma a validar sua absorção como um dispositivo para o conhecimento. Bergson defendia que o mecanismo do intelecto/conhecimento funcionava como o mecanismo do cinematógrafo. Nessa época, a ciência ganhava novas formas de análise, e muitos pensadores e filósofos associavam o método empírico, experimental e materialista a uma visão de mundo mecânica e "desencantada" (CURTIS, 2015, p. 63). Vários campos do conhecimento (do vitalismo ${ }^{14}$ de Hans Driesch à gestáltica) reivindicavam um olhar mais global sobre as disciplinas, uma compreensão mais profunda dos processos, que levasse em consideração os mais diferentes aspectos de um objeto. Algo que podemos hoje chamar de transdisciplinaridade. O discurso de Bergson em A evolução criadora (1907) reverberou na Europa e nos Estados Unidos, como um reflexo dessa "rebelião" científica. Bergson aceitava a hipótese da evolução da vida,

\footnotetext{
${ }^{14}$ Hans Adolf Eduard Driesch, embriologista e filósofo alemão cuja teoria negava que a explicação sobre a vida fosse reduzida a um fenômeno físico-químico.
} 
mas recusava o approach mecanicista, segundo o qual os organismos e processos precisavam ser divididos para ser compreendidos. Ele via a vida e o movimento como fluxos ininterruptos: a realidade do mundo existe em um fluxo permanente de transformações que pode, na percepção humana de tempo-espaço, parecer estável ou estático por um instante (CURTIS, 2015, p. 63).

O conceito central para Bergson é a noção de duração segundo a qual os organismos e objetos existem no tempo, sem o qual perde-se a compreensão de sua realidade. Esse conceito dialoga frontalmente com o pensamento de Jean Epstein, como veremos adiante.

No passado, Descartes e Newton reconheciam uma matemática imanente da matéria. Certos atributos ou qualidades, como extensão, forma, movimento, são mais objetivos e passíveis de se conhecer via matemática do que outros, como a cor, o som, o frio, o calor. A física clássica estabeleceu a tradução do mundo concreto para a linguagem matemática. Seguiram-se a esse entendimento as mais variadas subdivisões das ciências de modo a compartimentar o conhecimento em disciplinas, o que originou as áreas das humanidades, das exatas e das biológicas. Até o século XIX, por exemplo, não existia a palavra "biologia". Existia "medicina", que compreendia anatomia e fisiologia.

Na virada para o século XX, a compartimentação disciplinar e a física clássica já não davam conta de responder aos novos problemas e demandas da vida moderna. Foi quando as teorias de Einstein e da física quântica começaram a tomar corpo, ao mesmo tempo que uma nova percepção do mundo e da vida erigiam o pensamento científico moderno.

\section{Auscultar o mundo}

O método científico foi ganhando complexidade, enfrentando questões éticas, daí a reprodutibilidade do experimento, explicitadas suas condições de execução, assumirem o status de verdade inequívoca. Neste contexto de final do século XIX, início do XX, a fotografia e o cinema foram absorvidos como potentes aliados de descobertas e comprovações, e introduzindo novas discussões em torno dos métodos e das validações.

A observação é a atitude inicial na ciência. No cinema científico, a observação dos fenômenos acontece por meio de equipamentos de extensão da percepção. A 
demonstração de uma descoberta, a preservação e o estudo de eventos raros (ou em via de desaparecimento), o testemunho dos acasos maravilhosos são, como dizia Painlevé (1956), a matéria-prima para o cinema científico. A câmera vê e fornece a prova ao mesmo tempo - daí a força retórica das imagens que falam por si só. O objeto vive na tela.

Em um filme de medicina, esse poder da imagem viva é evidente: o corpo dissecado pode ser visto em detalhes por toda uma classe de estudantes, não apenas para os que estão mais próximos da mesa da dissecação. Na retórica científica, a validação das imagens pode ser dada pelas exposições do processo de obtenção das imagens, do motivo da pesquisa e do tempo empregado nas produções.

O cinema como linguagem que ausculta o mundo aglutina pensadores de todos os espectros da sociedade, como Jean Epstein, engenheiro de formação. Antes de se envolver com poesia e cinema, foi dedicado às ciências naturais e nunca abandonou uma certa consciência científica, sendo o primeiro a mencionar a matéria de que se ocupa o cinema, o tempo:

\footnotetext{
Nada, antes do cinematógrafo, nos permitia ampliar a variabilidade, tão limitada, do tempo psicológico íntimo à realidade exterior, de modificar experimentalmente a coordenada temporal da perspectiva dos fenômenos. [...] o olhar que o cinematógrafo nos permite lançar sobre uma natureza onde o tempo não é nem único nem constante pode ser mais fecundo que nosso hábito egocêntrico. A simples modificação de filmar, ao contrário, faz-nos remontar o curso normal do tempo e nos dá uma percepção do mundo tal como se esta fosse apenas uma das infinitas possibilidades. (EPSTEIN, 1955, p. 11)
}

Junto com Marey e Painlevé, Epstein é uma figura central no cinema científico. Um realizador/pensador que fez a ponte entre a ciência pura e a expressão cinematográfica, na busca por uma nova concepção do tempo. Enquanto Painlevé produziu e elaborou um pensamento em torno das práticas cinematográficas, Epstein voltou-se também para questões filosóficas que essa nova forma de percepção e expressão despertava. Uma de suas preocupações foi a questão da continuidade a partir da descontinuidade, a instauração de um paradoxo elementar do qual decorre a ideia de movimento criado a partir da imobilidade, da sequência de imagens paradas; a imobilidade, para Epstein, é apenas um movimento em potencial.

A preocupação de Epstein com o tempo e todas as suas implicações no cinema estava de acordo com o espírito do momento naquele início dos século XX: Albert Einstein publicou a sua teoria da relatividade em 1920, Epstein publicou seu primeiro 
ensaio, Bonjour cinéma, em 1921, e Henri Bergson publicou Durée et simultanéité em 1922.

O cinema encarna a problemática da representação imagética na quarta dimensão, algo que só pode acontecer no tempo. Para Epstein, a técnica do slow-motion, vista com frequência no cinema científico, engendra em si uma tensão dialética entre o movimento e o repouso, conferindo à imagem um sentido de transparência e revelando as etapas escondidas do movimento que permanecem invisíveis ao olho nu. Epstein comparou o slow-motion a um "microscópio do tempo" (CORTADE, 2012, p. 162) e ressaltou seu poder dramático, chegando a empregar a técnica em seu filme $A$ queda $d a$ casa de Usher, de 1928. É pensando no tempo que Epstein traça as relações entre o cinema, a ciência, a sensibilidade.

\section{Oceanógrafo moderno}

O desequilíbrio entre os orçamentos dedicados a filmes de entretenimento e às demais categorias é uma constante no desenvolvimento do cinema de pesquisa, principalmente porque boa parte da cinematografia científica demanda tecnologias de registro específicas. Como declarou o dr. Jean Comandon em meados da década de 1930, há um enorme contraste entre os recursos destinados à pesquisa cinematográfica das indústrias privadas e dos laboratórios universitários (HAMERY, 2013). Dependendo da aplicação, os recursos podem ser capital estatal, capital de uma empresa privada ou graças a pessoas aficcionadas por um assunto, espécie de "mecenas", como nos exemplos que serão dados a seguir.

O primeiro apoiador do cinema científico do tipo mecenas foi o príncipe Albert I de Mônaco, que percebeu a importância do cinema no campo da oceanografia. Apaixonado pelo mar, ele é reconhecido como o primeiro oceanógrafo moderno. Em 1906, doou 4 milhões de francos para fundar o Instituto de Oceanografia em Paris e estabelecer laboratórios marítimos capazes de missões distantes. A maior parte dos filmes oceanográficos tem sido feita assim desde então.

$\mathrm{O}$ alto investimento do príncipe Albert I tinha a ver com seu gosto por caça submarina, principalmente de grandes cetáceos. Paradoxalmente, ele é reconhecido como precursor da defesa da vida no mar. Se isso é verdade, é possível que suas pesquisas tenham-lhe acordado a consciência para que a preocupação se voltasse para a 
vida - não para a caça. ${ }^{15}$ De todo, modo, sua importância para o cinema oceanográfico é imensa. Ele se cercou de cientistas, profissionais do cinema e um fotógrafo-pintor, encarregado de fazer instantâneos fotográficos das viagens para depois reproduzi-los em tela. Suas expedições oceanográficas e cartográficas tornaram-se célebres e ricas em documentação (Fig. 33).

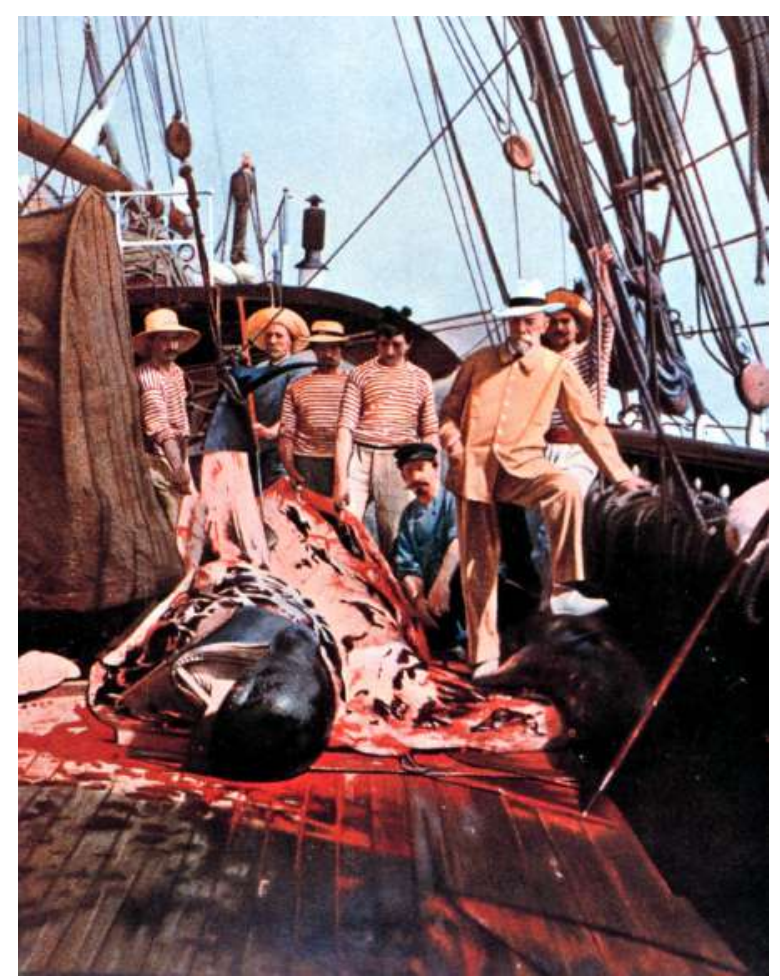

Figura 33: Príncipe Albert I observa a necrópsia de uma baleia a bordo do navio de pesquisa oceanográfica Princesse Alice, em 1897 (PRINCE ALBERT I, s.d.).

Para registrar as espécies excessivamente frágeis, cuja vida fora de seu habitat é efêmera, a embarcação contava com aquários aclimatados, onde se poderia filmar o mais rápido possível. Às vezes, centenas de metros de película eram gastas até que se obtivesse uma pequena cena interessante. $\mathrm{O}$ barco de filmagem também era equipado com uma cápsula de mergulho que atingia a profundidade de até dez metros, e um equipamento de iluminação subaquática. Foram produzidos assim filmes de rara beleza dos celenterados em movimento, os quais, depois de mortos e devidamente conservados, puderam ser analisados para que fosse compreendida a funcionalidade da sua anatomia. A projeção desses filmes no Instituto de Oceanografia era muito bem

\footnotetext{
${ }^{15}$ Não encontramos material que ateste a preocupação ecológica do Príncipe Albert I quando de suas expedições.
} 
recebida, tamanha novidade e curiosidade que o mundo submarino despertava, como seio de vida, mistério e perigo. As sessões, disputadíssimas, eram acompanhadas por uma aula expositiva.

A cápsula de mergulho do príncipe Albert I foi usada mais tarde pelo estúdio Universal na filmagem de Vinte mil léguas submarinas, de Stuart Paton, em 1916.

\section{Iniciativas privadas e os pop-sci films}

\section{Urban Company}

O período do cinema que se convencionou chamar de "primitivo", entre 1895 e 1913, foi na verdade uma época em que o cinema se apresentava como uma nova forma de apelo à sensibilidade, longe de ser pouco desenvolvida, como o termo sugere - hoje esse período é conhecido como cinema dos primórdios ou primeiro cinema. Foi um cinema de atrações diversas que coincidiu com um período em que a popularização da ciência estava na ordem do dia, assim como a reforma na educação ocorria em larga escala. A filmografia desse período, que conectava a ciência com entretenimento, ficou conhecida como popular science films, filmes de ciência popular, uma fórmula, quase um gênero, constituído pelos elementos prazer e instrução. Os primeiros anos do século XX marcaram o início da predominância do cinema narrativo e também a emergência dos filmes de ciência popular.

A Charles Urban Trading Company foi a primeira empresa a criar um catálogo significativo com seus filmes de pop-science. Junto com a Pathé e a Gaumont, vendiam filmes baseados em informação, ciência e educação, sob uma "estética do maravilhoso" (GAYCKEN, 2014, p. 11). Charles Urban, renomado comerciante de livros, levou seu prestígio para o negócio do cinema, com uma produção de qualidade que incluía filmes de atualidades, ciências e documentários do mundo natural, ou seja, o domínio da não ficção. Associado ao cientista e especialista em microcinematografia Martin Duncan, produziu a série The Unseen World - a Series of Microscopic Studies (1903), que oferecia ao público uma visão que só o cientista poderia ter, com imagens fotográficas de movimentos nunca vistos. Vários desses filmes eram acompanhados por uma leitura explicativa, concisa e alegre, o que transformava a obra cinematográfica em um espetáculo herdeiro das apresentações de lanterna mágica e dos lightening sketches. ${ }^{16}$

\footnotetext{
${ }^{16}$ Performance em que o artista desenhava ao vivo para o espectador (BARBOSA JR., 2005, p. 41).
} 
A série The Unseen World levou um público de todas as idades e classes sociais a lotar as salas de cinema durante nove meses com o slogan "We put the world before you" [nós colocamos o mundo à sua frente]. Havia sessões com temas que variavam entre ciências, geografia e história durante a tarde toda, além de música nos intervalos. Oferecer conhecimento do jeito mais prazeroso e interessante possível era o caminho para ampliar o público.

Os filmes da Urban Company caíram no gosto popular, porque apelavam ao mesmo tempo para o lado sensorial e para as faculdades intelectuais. Educativos e divertidos levavam o público a uma intimidade com a fidedignidade dada pela câmera. O panfleto publicitário bradava: "Cinco minutos de imagens vivas podem conter mais conhecimento e de uma forma mais interessante e efetiva do que uma hora de lição oral!" (GAYCKEN, 2014, p. 44).

A necessidade de ampliar o mercado levou a Urban a desenvolver o processo kinemacolor, que consistia em um sistema de duas cores aditivas, mais eficaz do que o processo de stencil. O kinemacolor foi um avanço tecnológico que ensejou a produção de diversos filmes que tratavam de ótica e de reações químicas, mobilizando inclusive artigos em revistas de ciência popular. Na virada do século, o uso da cor no campo científico evocava a aproximação com a realidade, e ao mesmo tempo com a fantasia, dois modos de se olhar um mesmo objeto: a ótica do realismo e a ótica da sensibilidade, do espetáculo.

O mundo microscópico pode ser fascinante e horroroso, deslizando entre o horror e a comédia, tendendo mais para a comédia. Um dos procedimentos de filmagem e montagem é o trabalho para a desfamiliarização das coisas do cotidiano. Em Cheese Mites (1903), por exemplo, o próprio Martin Duncan faz o papel de um professor em seu desjejum, enquanto lê jornal com uma lupa e come pão com queijo. Em um movimento inesperado, ele leva a lupa junto ao pão e se surpreende com os ácaros que habitam o queijo. O corte cinematográfico leva o espectador a uma imagem de microscopia na qual os inusitados aracnídeos passeiam pela tela de cinema. Nesse período, em que o enquadramento predominante no cinema era o enquadramento frontal, chama atenção o fato de que, em Cheese Mites o tomada fosse lateral.

Um dos colaboradores da Urban foi Percy Smith, que entrou para o time da empresa após a saída de Duncan. Sua personalidade extravagante diferia do modo mais compenetrado e rigoroso de Duncan. Smith descrevia-se como alguém de fora da academia, um cientista amador, diferente de Duncan. Inventivo, ele inicialmente 
desenvolveu dispositivos caseiros para realizar seus filmes, como o sistema de alarmes para lembrá-lo de capturar as fotografias para um time-lapse que podia levar até dois anos para ficar pronto.

O comprometimento da empresa com o entretenimento instrutivo permanecia, mas Smith acrescentou o humor e se dedicou a colocar o público em contato com as maravilhas do mundo microscópico da vida cotidiana. Smith também trouxe a técnica da animação quadro a quadro e tratou de forma antropomórfica algumas de suas estrelas: moscas, formigas, aranhas. No filme To Demonstrate how Spiders Fly (1909), Smith construiu um boneco articulado de aranha e o animou de modo a simular a ampliação da escala e a desaceleração do tempo (Fig. 34).

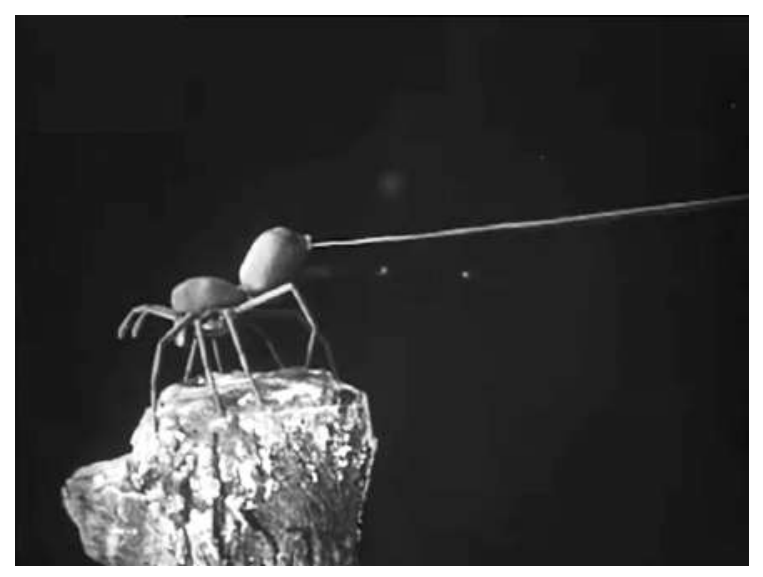

Figura 34: Cena de To Demonstrate how Spiders Fly. O intertítulo inicial do filme explica que foi construído um modelo mecânico à imagem da aranha. Ao final, há um corte para uma aranha verdadeira na teia, de modo a assegurar o caráter científico do filme.

O antropomorfismo também é visível em The Acrobatic Fly (1910), no qual a habilidade e a força da mosca equivalem às características humanas em acrobacias com um palito de fósforo, com um haltere em miniatura e em dupla com outra mosca (Fig. 35). O comportamento humanizado da mosca sugere que elas são inteligentes e que teriam realmente a intenção de se apresentar ${ }^{17}$. O filme dividiu o público, que inicialmente pensou se tratar de um filme de efeitos com animação. As referências a acrobacias, malabarismos, além da disposição do enquadramento traziam a ideia de um

\footnotetext{
${ }^{17}$ A tendência à humanizar o comportamento animal seguiu com força pela cinematografia de animação do século XX, primcipalmente com os filmes de Walt Disney, a partir de meados dos anos 1920. Em 1912, Winsor McCay fez o desenho animado How a Mosquito Operates, em que a personagem principal, um mosquito, porta cartola e valise e afia o bico em um esmeril antes de atacar a vítima. No mesmo ano, Ladislas Starevich produz a animação em stop-motion Te Cameraman's Revenge, a história de traição personificada por gafanhotos.
} 
espetáculo circense, a qual é reforçada pelas explicações dadas à imprensa por Smith a respeito do "treinamento" dado às moscas (GAYCKEN, 2015, p.62).

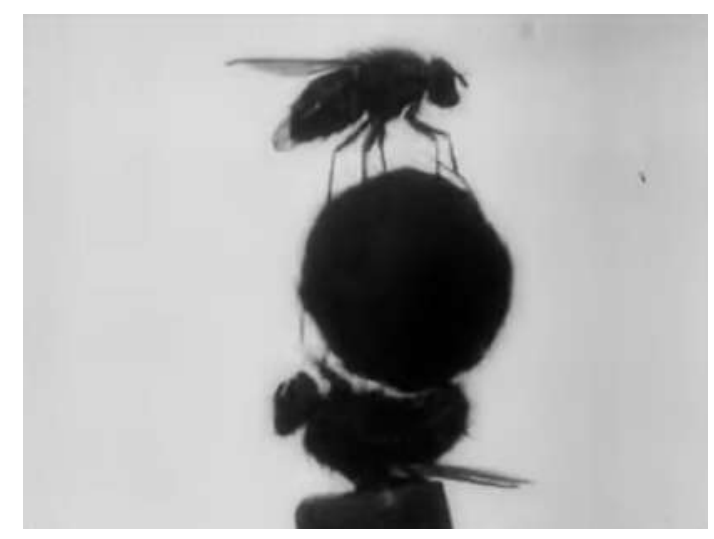

Figura 35: Cena de Acrobatic Fly. No filme, uma mosca fixa em um pedestal executa manobras com objetos em parceria com outra mosca, em uma cena espetacular para o espectador do início dos anos 1900. Smith insistiu que o filme resultara de investigações científicas prévias, fornecendo detalhes técnicos de como produzira as tomadas.

O antropomorfismo também se apresenta nos filmes de plantas florescendo em time-lapse, nos quais elas evidenciam ter consciência com movimentos graciosos próximos a um balé - um fenômeno animista que sugere a existência da alma na planta. Sua obra-proma Birth of a Flower (1910) nunca foi um marco nessa temática e nunca deixou de ser distribuída.

O trabalho de Smith na Urban expõe as fronteiras transgressoras entre o amador e o profissional, o científico e o não científico, o entretenimento e a instrução. Ao mesmo tempo que tinha habilidade e paciência com os processos de laboratório, de microscopia e time-lapse, Smith tinha extraordinário know-how em produção cinematográfica e profundo entendimento do potencial estético dr suas imagens modernas para o início do século XX. Durante a primeira guerra mundial, Smith trabalhou como fotógrafo naval e fez uma série de filmes com animações de mapas. Depois da guerra, dedicou-se à série Secrets of Nature, do British Film Institute, de 1922 até meados da década de 1930, quando o som foi integrado às produções. A série mudou o nome para Secrets of Life e durou até sua morte, em 1945.

Outro colaborador da Urban foi o famoso médico cirurgião dr. Eugene-Louis Doyen. Mestre em cirurgias do abdômen, Doyen oferecia as melhores vistas de operações raras, e seus filmes eram frequentemente utilizados para a melhoria de sua 
própria prática e para treinamento de estudantes. No campo da educação, Doyen já tinha uma vasta produção de publicações de atlas de anatomia e de fisiologia, defendendo que o uso de filmes permitiria que os cirurgiões reduzissem os movimentos supérfluos e o tempo de cirurgia. Os filmes também ajudariam a reduzir a necessidade de vivissecção em auditórios (TOSI, 2005, p. 167). De fato, o cinema também possibilita a visualização da mesma operação inúmeras vezes, promovendo a evolução da ciência.

Frequentemente, seus filmes escandalizavam, mesmo as plateias formadas por colegas da medicina. Em Paris, Doyen enfrentou dificuldades e protestos ao exibir algumas de suas produções (LEFÈBVRE, 2010, p. 33). Além do aspecto, de certa forma escatológico, a exposição de um momento íntimo do paciente causava repugnância e aflição frente à brutalidade do corpo humano aberto (Fig. 36).

A resistência a seus filmes na França pode ser devida a sua personalidade extravagante e bastante afeita à exposição e a autopropaganda, o que não condizia com o comportamento exigido na academia. A projeção indiscriminada dos fragmentos de seus filmes em eventos populares, sem a contextualização necessária, provocava indignação na classe médica. Já no Reino Unido, na British Medical Society, em Edimburgo, seus filmes foram bem recebidos - uma histerectomia e uma craniotomia. Devido ao sucesso, foram solicitadas projeções extras.



Figura 36: Imagem extraída em 1902 do filme em que o dr. Doyen separa as duas irmãs siamesas Doodica e Radica (DR. DOYEN, s.d.). Este filme gerou protestos da classe médica, que o acusava de fazer uso comercial do procedimento, ofendendo a dignidade da profissão. 
Para produzir seus filmes de cirurgias, foram necessárias melhorias na câmera e no projetor, de modo a suportar bobinas de filme com maior duração do que as que se usavam na época. Outra dificuldade era a baixa sensibilidade da película. Uma das soluções seria filmar a céu aberto com um cadáver, proposta que foi rejeitada por Doyen. Desenvolveram-se então lentes mais luminosas para que ele pudesse executar uma operação real em um paciente vivo, em uma sala de cirurgia.

Doyen também se interessava pela parte técnica da cinematografia, bem como pelas áreas de física, eletricidade e balística. A partir de 1907, passou a trabalhar em colaboração com o mecânico Auguste Hullin, que possuía uma oficina de precisão onde desenvolveram os protótipos de câmera e de projetor para filmagem em cores patenteados em 1912. Ainda que o aparelho apresentasse falhas na estabilidade e na superposição das cores vermelho-verde-azul, evidenciou mais um exemplo do avanço tecnológico para atender a demanda científica.

\section{Pathé}

Na França, a Pathé foi outro empreendimento de sucesso no ramo dos filmes de ciência popular. Os filmes do gênero sci-pop floresceram na década de 1910 e absorveram em parte o público dos trick-films (filmes de efeitos), introduzindo um senso de realidade em imagens distorcidas temporal e espacialmente. O período de 1908 a 1910 fora especialmente produtivo para o desenvolvimento da microcinematografia na biologia, com destaque para as inovações de Julien von Ries, Lucienne Chevroton e Fréd Vlé, que desenvolveram técnicas para a melhoria da qualidade da imagem e diminuição dos intervalos entre as imagens.

Homem de visão comercial, Charles Pathé já trabalhara com exibição de filmes em feiras e espetáculos de variedades, quando foi procurado pelo estudante de medicina Jean Comandon. Influenciado pelo trabalho de Marey, que também havia trabalhado com microcinematografia, já em 1891, Comandon pretendia usar a microcinematografia em sua tese de doutorado para estudar micróbios como o Trypanosoma e o Spirochetta da sífilis. Para ele, era o único meio de registrar e medir os movimentos de microorganismos, além de conservar todo a preparação da observação ao microscópio. Comandon foi o primeiro cientista a exibir material em cinema à Academia das Ciências de Paris, em 1909, como parte integrante de sua tese.

Pathé tinha interesse em variar a programação para atrair uma burguesia cada vez mais instruída e exigente. Além disso, havia um mercado crescente para os filmes 
educativos, como uma resposta ao movimento da reforma na educação em curso naquele período, em que se reivindicava, entre outras coisas, a inclusão do cinema em sala de aula. Para Pathé o cinema era o "jornal, a escola e o teatro do amanhã" (in GAYCKEN, 2015, p. 99). Ele concordou em apoiar Comandon, fornecendo-lhe o equipamento - consideradas as melhores câmeras da época - e um pequeno laboratório. Com este estímulo, Comandon apresentou sua tese com sucesso.

Após sofrer algumas dificuldades no emprego do ultramicroscópio, tornou-se especialista na técnica, sendo convidado por Pathé para estabelecer uma unidade de produção de filmes científicos. Assim, Comandon apelou a vários colegas cientistas de outros campos para juntos realizarem o que veio a ser o catálogo da Pathé-Ensino, uma enorme filmoteca de ciências.

Além da ultramicrocinematografia, Comandon fez filmes com raios-X e com time-lapse, dos quais um dos mais conhecidos é La croissence des végétaux, ou $O$ crescimento dos vegetais (1929) (Fig. 37).


Figura 37: Sequência do desabrochar do dente-de-leão em $O$ crescimento dos vegetais. Um aspecto que foge à análise dos filmes de Comandon é a retórica poética dos textos que ele mesmo redigia para acompanhar as projeções. Neles, mesclava-se o rigor da descrição científica ao prazer literário, o que tornava a exibição dos filmes um espetáculo sinestésico.

A colaboração Comandon-Pathé iniciou o ciclo de filmes de ciência popular na França e contou com outros nomes, como o do banqueiro Albert Khan, que providenciou espaço e recursos financeiros para pesquisa e desenvolvinemto de equipamentos. Khan criou uma parceria com a Universidade Sorbonne, fornecendo bolsas de pesquisa para estudantes investirem em produções fotográficas e cinematográficas. $\mathrm{O}$ uso comercial pela Pathé dos filmes não agradava à comunidade científica, mas Comandon continuou com seu trabalho sério e apaixonado, promovendo avanços técnicos e fazendo filmes que ainda hoje podem ser vistos em sala de aula.

Depois da colaboração com a Pathé, Comandon trabalhou para o Instituto Pasteur. Mais tarde, em 1920, tornou-se chefe de serviços de cinematografia na Direção de Pesquisas Científicas e Industriais e de Invenções (organismo ligado ao Ministério da 
Instrução Pública). Não era afeito à publicidade, ao contrário de Doyen, mas fornecia com gosto informações a quem se mostrasse interessado em seu ofício. Em 1921, deu uma entrevista a Pierre Desclaux, da revista Cinémagazine, em que deixou claro seu método de trabalho, sempre a partir de uma demanda específica, a qual visava contribuir para o aperfeiçoamento e aprofundamento em um campo do conhecimento:

Por exemplo, um simples golpe de martelo sobre um prego é um movimento complexo. Que peso e qual forma deve ter o instrumento? De qual altura deve ser o golpe [Fig. 38]? Em qual instante o trabalhador deve imprimir maior esforço para obter um choque mais forte com o mínimo de fadiga? Para responder a estas questões, foram encomendados filmes cuja análise permite entender a trajetória do martelo no tempo e no espaço. É um estudo que permite mudar a forma do instrumento e a técnica de trabalho. (COMANDON in DESCLAUX, 1921, p. 15)
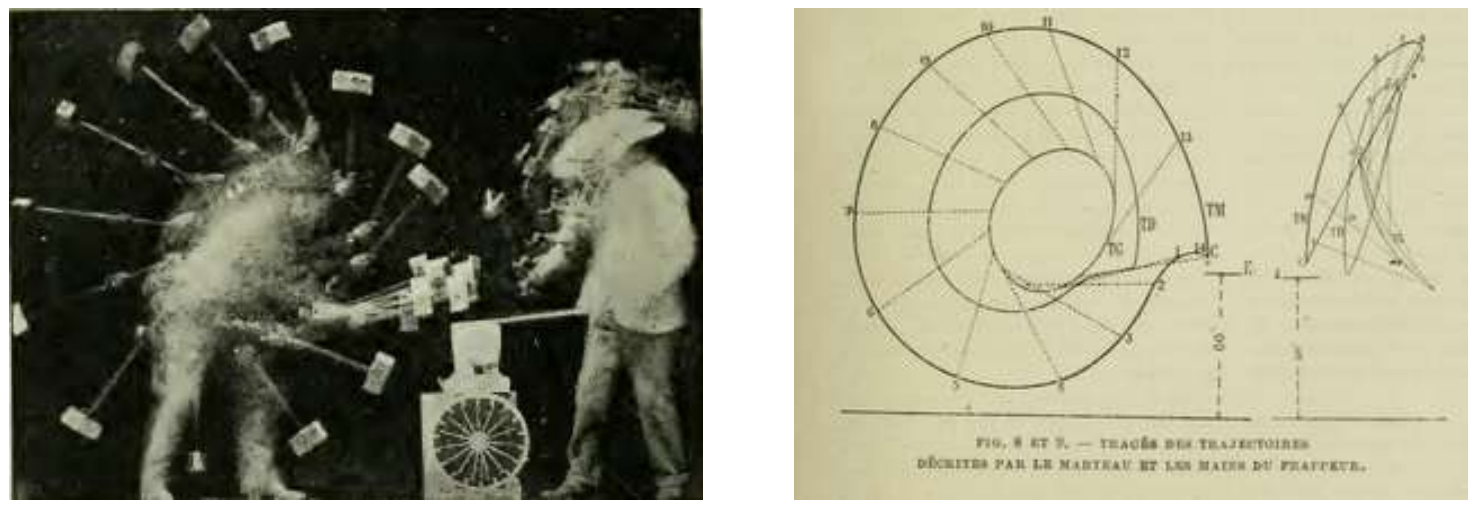

Figura 38: Les mouvements de l'ouvrier dans le travail professionnel (1895), cronofotografia e estudo Charles Frémont, colaborador efêmero de Marey (DEMAZEL, 2016). ${ }^{18}$

Comandon participava de encontros com artistas e cineastas da vanguarda, como Germeine Dulac, para quem seus filmes (e os filmes de ciências em geral) eram fonte de inspiração. Esses encontros reforçavam em Comandon a consciência da natureza espetacular de suas imagens, da força estética, das metáforas possíveis. Centenas de pequenos filmes, de poucos metros, feitos por ele antes de 1920, e que alimentavam a

\footnotetext{
${ }^{18}$ No bloco da bigorna, um cronômetro indica duração de um segundo e meio, durante os quais quinze tomadas equidistantes foram feitas. Assim, Frémont pôde estudar as trajetórias, calcular a velocidade do martelo e medir o trabalho. Ele estima o trabalho da massa em cerca de $22 \mathrm{~kg} / \mathrm{segundo}$. Ele também observa que, ao empregar essa força "o trabalhador só pode trabalhar imediatamente por alguns minutos: é necessário um descanso antes de cada retomada do trabalho - além disso, é o tempo necessário para aquecer a peça". Concluiu com isso o que chamou de "lei do menor esforço": o corpo do trabalhador instintivamente encontrou o movimento certo para fazer o máximo esforço com o mínimo de fadiga. Nesse quadro, a fadiga se torna uma "regulação espontânea do comportamento", um "julgamento imanente que o corpo exerce sobre si mesmo" (FOREST, 2001, p. 3-125).
} 
cinemateca de ensino público, desapareceram, seja por falta de conhecimento em preservação de filmes, seja por desconsideração à sua importância.

\section{Gaumont}

Ocupando o segundo lugar no mercado de filmes de ciência popular na França estava a Gaumont, que a partir de 1910 incorporou o gênero a seu catálogo. O interesse de Léon Gaumont pela cinematografia científica tem forte relação com sua própria formação escolar: apesar de ter sido excelente estudante, precisou interromper seus estudos aos 16 anos, por falta de recursos financeiros. Seguiu sua formação intelectual de maneira autodidata e em instituições públicas e gratuitas. Talvez por isso, Gaumont tivesse uma compreensão do papel decisivo da educação na sociedade e interesse intelectual genuíno na divulgação científica. A ciência para ele era um "equalizador social" (GAYCKEN, 2015, p. 101). Seu interesse pelo conhecimento não era menor do que seu tino para negócios e para estabelecer relações e parcerias frutíferas. Depois de trabalhar em uma empresa de equipamentos e suprimentos para cinema, comprou a companhia, que passou a se chamar L. Gaumont et Cie.

Diferentemente da Pathé, onde os filmes de popular science eram considerados como qualquer outro filme comercial, na Gaumont o cinema era visto como um meio científico e educacional de um modo mais sério, sem descartar, é claro, o lado comercial. O catálogo Enciclopédie (1921) trazia os filmes classificados em astronomia, física, química, mineralogia, geologia, botânica, zoologia, medicina, higiene e cirurgia, que costumavam ser encaixados em programas maiores com outras variedades. Ao longo dos anos, entretanto, a catalogação tornou-se menos criteriosa e passou a incluir filmes que pouco ou nada tinham de científico. $\mathrm{O}$ aspecto espetacular dos filmes fazia parte da publicidade da empresa, com ênfase nas pesquisas da companhia em cor e estereoscopia. A série Études des fleurs (1910), que consistia em uma série de tomadas de vasos de flores em rotação, pouco tinha de científica em seu conteúdo. Nesse caso, a cor e a estereoscopia eram vendidas como os aspectos científicos da produção.

Os filmes de ciência popular eram iminentemente intertextuais, visto que havia uma justaposição de temas, estilos e linguagens alheios ao campo estritamente científico. Deux escargotphages (1913), por exemplo, apresenta dois escargots que duelam até a morte, em cenas de violência explícita: um documentário de animais ao mesmo tempo que uma ficção de assassinato. A surpresa violenta também ocorre em L'air liquide et ses applications (1911), em que uma enguia congelada no ar líquido 
sofre um golpe e se quebra em um sacrifício trágico espetacular. Em cenas de retratam da reprodução de algumas espécies, o tratamento dado ao ato sexual pode evocar um certo grau de erotismo, como no romance entre os cavalos marinhos e os polvos de Painlevé.

A forma de apreciação desses filmes tem menos a ver com o conteúdo em si do que com a novidade da experiência da ilusão cinemática. É uma fruição enraizada na noção de fotogenia do objeto, da sua singularidade plástica, mas também na ideia de narrativa, de uma história a ser contada, com as estratégias de montagem etc.

Iniciativas Estatais: França, Alemanha, Canadá, Estados Unidos, Rússia e Brasil

Em diversos países, os órgãos estatais ligados a ciência, tecnologia, saúde e educação criaram secretarias ou subdivisões encarregadas de encaminhar demandas e propiciar condições de produção. Por conta da reputação de Paul Painlevé, pai de Jean Painlevé, foi criado na França o Subsecretariado de Estado de Invenções e de Experiências Técnicas, que, depois da I Guerra, transformou-se em Divisão de Pesquisas Científicas e Industriais e de Invenções. Sendo um órgão ligado ao Ministério da Instrução Pública, esta divisão atuava como interface entre Estado e indústria, promovendo pesquisa tecnológica para reestabelecer a ordem econômica no pós-guerra. No início, seu objetivo era registrar experimentos e o funcionamento de máquinas de armamentos.

Boa parte do desenvolvimento tecnológico no cinema voltado para a ciência deveu-se às demandas militares, cujos altos financiamentos foram justificados pela necessidade da defesa nacional. Lucien Bull, antigo colaborador de Marey e pioneiro na captura de imagens em alta velocidade, recebeu auxílio do Subsecretariado de Invenções do Ministério da Defesa da França para acoplar a seu equipamento um disparador de faíscas luminosas. Foi possível, assim, registrar o lançamento de balas de projéteis a altíssimas velocidades, como a 5 mil e mais tarde até 20 mil imagens por segundo, e estudar a balística com precisão (Fig. 39).

Na Alemanha, na Inglaterra e nos Estados Unidos, também foi instituído o uso do cinema com finalidade militar, com bons resultados tanto na performance dos soldados como no desenvolvimento bélico. Os estudos de movimento em cinema também contribuíram para a fabricação de próteses para recuperação dos membros mutilados em campo de batalha. 


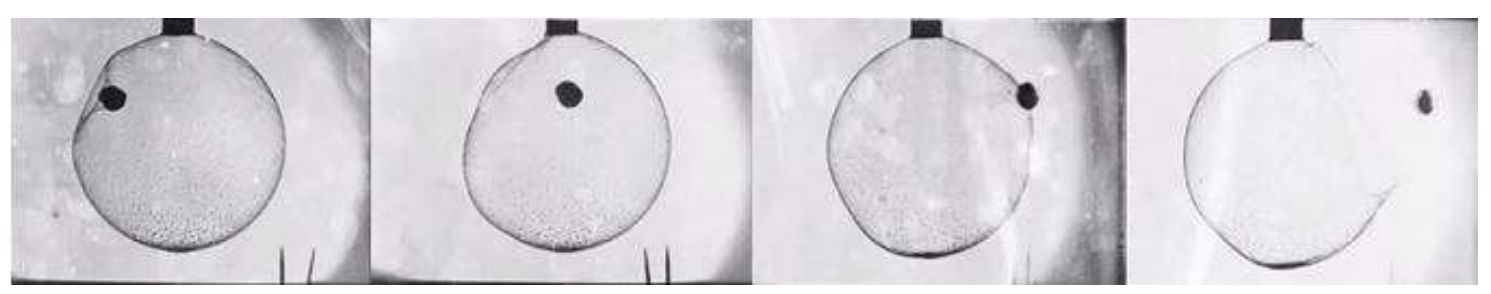

Figura 39: Registro de Lucien Bull, Balle traversant une boule de savon (1904) (LUCIEN BULL, 2016). Mais uma vez, a percepção é estendida pela câmera e revela uma face inesperada da realidade. Após ser perfurada pela esquerda, a bolha permanece inteira por uma fração de segundo, até a perfuração do lado oposto.

Uma iniciativa de sucesso durante muitos anos foi o Instituto para o Filme Científico (IWF), na Alemanha, criado pelo prof. Gottard Wolf. É o exemplo mais representativo de uma organização nacional centralizada, com participação regional. $\mathrm{O}$ Reichsanstalt für Film und Bild in Wissenschaft und Unterricht, criado em 1934, produziu centenas de filmes de pesquisa e ensino, distribuídos largamente pela Alemanha, já contando com recursos tecnológicos de ponta, animações infográficas, microfilmagem, raio-x etc. Em 1956, dividiu-se em dois órgãos: o Institut für Film und Bild, em Munique, e o Institut für den Wissenschaftlichen Film, em Göttingen. Este continuou responsável pela aplicação do cinema à pesquisa e pela produção de filmes para ensino. Seu catálogo tem um total de 6.600 títulos desde o final do século XIX, incluindo produções etnográficas e sobre espécies animais já extintas.

O IWF contava com pessoal altamente qualificado, recursos tecnológicos de ponta, orientação científica precisa, e era sem fins lucrativos. Dos cerca de cem funcionários, $20 \%$ eram especialistas em diversos domínios (medicina, física, biologia, engenharia) e também tinham conhecimentos técnicos em cinema, conseguindo fazer a ponte produtiva entre a equipe de cinema e os cientistas que traziam suas demandas. Cerca de quinze funcionários encarregavam-se da direção de fotografia: quatro pessoas em micrografia e o restante para captura de imagens em biologia, como plantas em estufa ou animais em cativeiro. Assim, se uma equipe de pesquisa necessitava de material fílmico para compor sua fonte de dados, esta poderia solicitar o apoio do IWF. Conforme o custo, o próprio instituto arcava com as despesas, contanto que o material ficasse disponível em seus arquivos. O IWF também produzia publicações a partir das pesquisas.

Em 1961, foi construído um edifício especial para abrigar o instituto, com estúdios, salas de reunião, laboratórios e arquivos. Um laboratório específico para 
captura de imagens fotográficas em alta velocidade - até 2 milhões por segundo - e um ateliê eletromecânico foram construídos, e uma extensa gama de aparelhos para adaptação a novas demandas em pesquisa forma adquiridos. Esta estrutura foi ameaçada de perder os recursos federais em 1996, em face da acusação de que o instituto "negligenciou o desenvolvimento em gravação digital e não tinha competência para transmissão digital de material visual" (SCHIERMEIER, 1998, s.p.). Em 2001, a entidade passou a se chamar Instituto do Conhecimento e Mídia (Wissen und Medien), com declínio de suas atividades e encerramento em 2010.
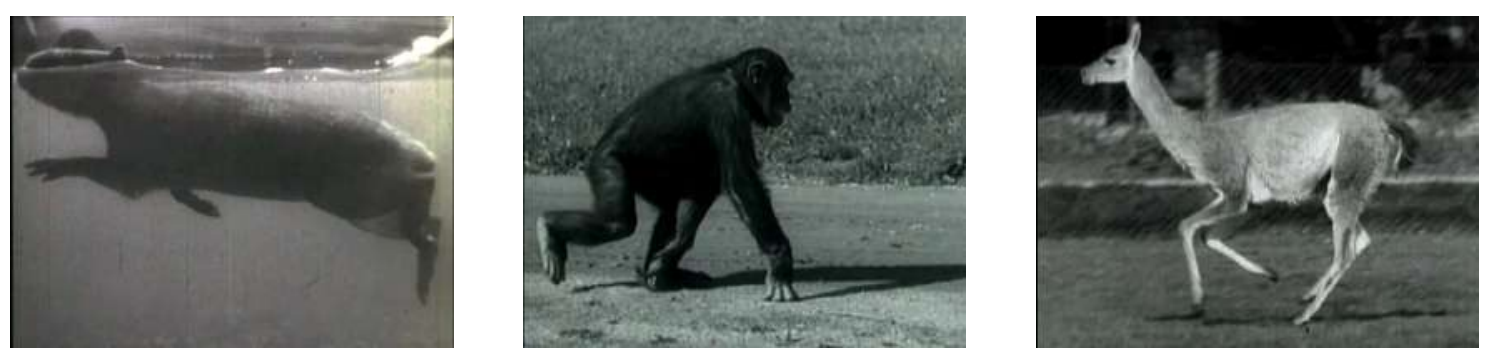

Figura 33, 34 e 35: Imagens de filmloops, tipo de produção em que os animais eram captados em movimento, que era reduzido a sua unidade mínima, um passo (ENCICLOPAEDIA CINEMATOGRAPHICA - DEMO VIDEO, circa 1950). O IWF repetia essa unidade algumas vezes em loop na montagem, o que possibilitava melhor observação.

O que o IWF promovia de interessante era que pesquisadores de todo mundo podiam contribuir com excertos de filmes, desde que obedecessem às seguintes premissas: (1) que o fenômeno retratado só pudesse ser visualizado na forma de cinema; (2) que houvesse grande probabilidade de não repetição; e (3) que permitisse comparações e medidas. Também eram admitidos os single concept films, todos realizados em dezesseis milímitros (figs. 33 a 35), esses ciclos de movimento assemelham-se ao que hoje no mundo digital chamam-se os gifs animados. Assim, criou-se um imenso banco de dados chamado Encyclopaedia Cinematographica, com milhares de filmloops com ciclos de movimento dos animais, acompanhados de um texto explicitando o objetivo da pesquisa, os métodos, as condições de filmagem. Tudo arquivado como se fosse em um museu de imagens em movimento.

No Canadá, o National Film Board (Instituto Nacional do Filme) cumpriu papel semelhante na área da divugação científica. No início dos anos de 1930, o imenso território canadense era povoado de maneira esparsa. A comunicação entre as comunidades e povoados era difícil, o que tornava complicado estabelecer um diálogo de unidade e de pertencimento a uma mesma nação. 
Em 1918, o governo canadense instituiu a Canadian Government Motion Picture Bureau, a primeira empresa estatal dedicada à produção cinematográfica, com o intuito de promover o comércio e a indústria, exibindo os recursos humanos, agrícolas e industriais, além de apresentar as cidades em desenvolvimento, a vida árdua do produtor rural, os meios de transporte, os esportes. O objetivo era mostrar o Canadá aos outros países e aos canadenses. Entre as décadas de 1920 e 1930, o Bureau produziu centenas de filmes, distribuídos nas Américas e na Europa.

Até 1934, foram criados apenas filmes silenciosos e, a partir de então, unidades de produção locais iniciaram a produzir cinema independentemente do Bureau. Com as atividades em declínio, o primeiro ministro solicitou que o documentarista escocês John Grierson propusesse reformas para revigorar a produção da empresa. Assim, o Bureau passou a ser o National Film Art, que, em 1939 passou a se chamar National Film Board (NFB), ou Office National du Film.

Ao recontar a história da instituição, é possível perceber como tomou forma um das entidades mais prolíficas na produção de cinema voltada ao conhecimento, que soube incorporar elementos de diversas culturas, importar talentos e desenvolver tecnologia para a criação de filmes memoráveis. A incumbência de Grierson era de que o NFB fosse o "olho do Canadá" (KERMOYAN, 1985, p. 85) e captasse todos os aspectos do país, sua gente, suas ideias, a multiculturalidade, e que também tivesse um caráter social e valor científico.

As produções do NFB voltaram-se sempre à inovação e à excelência, à formação e ao treinamento de profissionais, além de pesquisa em cinema, vídeo e meios digitais. Com a entrada de Norman McLaren em 1941, a estatal passou a produzir também animações, cujo experimentalismo e a inventividade levaram o NFB a se popularizar. Suas séries sonorizadas diretamente na película são frutos de pesquisas intensas sobre o suporte fílmico na busca pela máxima expressão do meio. Filmes sem uso de câmera, com desenho direto na película, pixilation, animação com areia, óleo sobre vidro e computação gráfica foram inovações que trouxeram notoriedade ao NFB.

Em 1967, alguns de seus integrantes fundaram a Multiscreen Corporation, que mais tarde passou a ser a Imax Corporation, especializada em câmeras de alta resolução para projeções gigantes. A Imax e o NFB desenvolveram projeção estereoscópica em grande formato, setenta milímetros. O trabalho de pesquisa e aperfeiçoamento em técnicas cinematográficas foi essencial para as demandas científicas que o NFB se encarregou de produzir. 
Nos Estados Unidos o Physical Science Study Cometee ${ }^{19}$ (PSSC) representou o esforço para a modernização do ensino de física no pós-guerra. Na década de 1950, havia uma percepção de que o método convencional do ensino de ciências, a partir de livros e giz no quadro negro, não estimulava a atitude dos estudantes em direção à formulação e resolução de problemas pela tecnologia, muito menos à elaboração de novas hipóteses. Em 1956, dois professores do MIT (Massachussets Institut of Technology), Jerrold Zacharias e Francis Friedman, fundaram o PSSC, iniciando um movimento de criação de novos materiais didáticos com ênfase na compreensão, mais do que na memorização mecânica.

Com o lançamento do satélite artificial Sputnik em 1957 pela antiga União Soviética, o medo de ficar para traz em desenvolvimento tecnológico levou o governo norte-americano a injetar recursos no National Science Foundation, em uma nítida compreensão da função estratégica do conhecimento científico no campo da educação; mais que isso: "a educação científica no ensino fundamental era vista como uma arma dentro do arsenal americano para o controle das ambições de domínio da União Soviética" (RUDOLPH, 2006, p. 1).

Nesse período, o PSSC já estava em fase de estruturação e acabou se beneficiando com os recursos vindos do governo. Entre 1958 e 1959, o novo método proposto pelo PSSC entrou em fase de teste em 250 escolas. Além de filmes, foram disponibilizados para todas as escolas públicas dos Estados Unidos livros, orientação para experimentos de baixo custo e avaliações padrão. Para a produção dos filmes, Zacharias estabeleceu duas regras: (1) não poderia haver atores fazendo o papel de cientistas, com aventais brancos e sotaque estrangeiro (o que reforçaria o estereótipo do cientista europeu na América); e (2) o diretor-professor da produção deveria determinar por completo qual a melhor abordagem para o tema do filme. Dessa forma, os apresentadores dos filmes foram os próprios centistas pesquisadores e professores, sempre em traje formal, terno e gravata. Vários cientistas envolvidos entraram em contato pela primeira vez com uma produção de cinema através do PSSC.

O primeiro filme foi produzido no MIT, Pressure of Light (1958), em que o prof. Zacharias dá uma aula expositiva a respeito da demonstração da pressão da luz, com vários equipamentos de laboratório. O pesquisador mostra-se um tanto tímido em

\footnotetext{
19 Leitura complementar a respeito do PSSC está disponível em: http://www.compadre.org/portal/pssc/pssc.cfm.
} 
sua relação com a câmera e poucas vezes encara o espectador frontalmente (figs. 36 a $38)$.
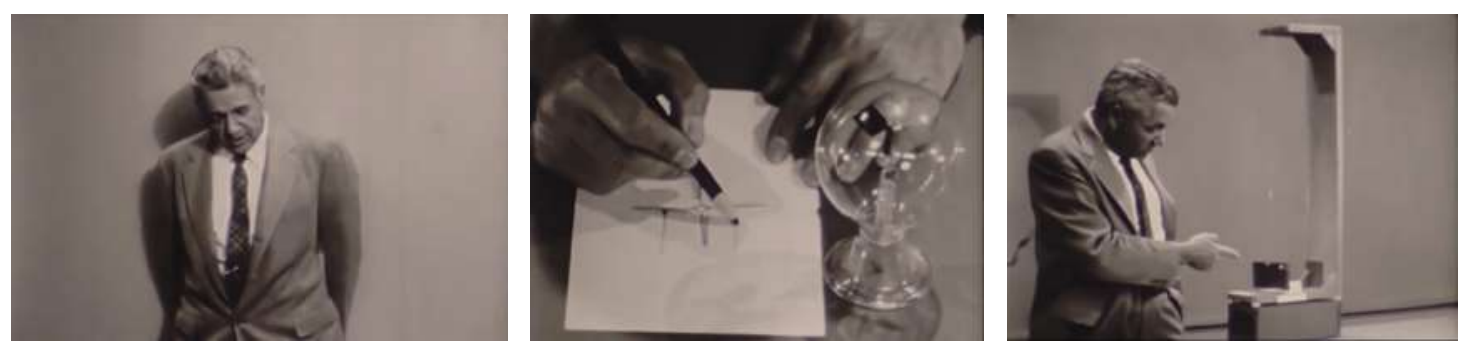

Figuras 36, 37 e 38: Cenas de Pressure of Light, primeiro filme do PSSC, estrelado pelo prof. Jarrold Zacharias. Com o objetivo claro na melhoria do ensino de física, Zacharias enfrenta a câmera para oferecer aos estudantes uma maneira nova de pensar os problemas que a disciplina propõe. Na primeira imagem, ele parece constrangido, contra a parede, em uma postura de timidez explícita.

A decupagem do filme é de certa forma rígida, com poucas mudanças de enquadramento e movimento. Esse tratamento muda em Frames of Reference (1960), em que é possível notar uma outra desenvoltura na direção, na elaboração da linguagem, sensivelmente mais refinada em relação a Pressure of Light (figs. 39 a 41). Com experimentos criativos e relativamente simples - embora engenhosos -, o espectador é provocado desde o primeiro plano a especular sobre a relatividade dos pontos de vista, em cenas que tratam espaço e movimento.
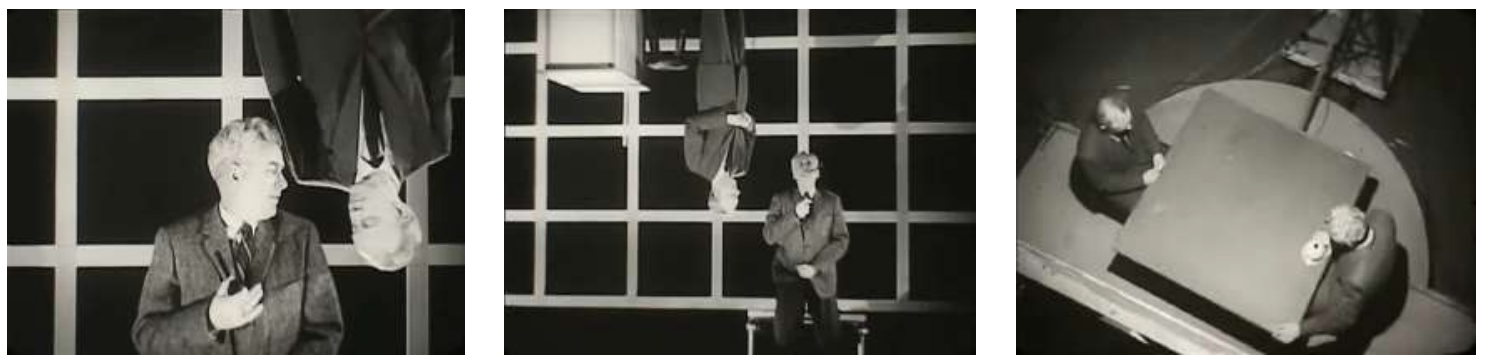

Figuras 39, 40 e 41: Cenas de Frames of Reference. No filme, os professores da Universidade de Toronto Donald Ivey e Patterson Hume dialogam entre si e com o espectador, jogando com a percepção do movimento e colocando em cheque o senso comum. A produção não apenas revela os métodos pelos quais cada experimento é concebido, como também desnuda o aparato cinematográfico por trás das cenas. É uma obra que justifica exemplarmente o uso do cinema no ensino e representa um dos pontos altos da produção do PSSC.

De fato, situações surpreendentes e bem elaboradas dificilmente poderiam ser reproduzidas em salas de aula regulares. Em todos os filmes, entretanto, a imagem é fortemente apoiada no discurso verbal. Praticamente inexistem os momentos de distensão do olhar, cenas em que algo inesperado ocorre, ou imagens que ofereçam 
algum espetáculo estético. O último filme realizado pelo PSSC foi Velocity of Atoms (1964). Assim, o cinema foi incorporado às aulas de física nos Estados Unidos durante os anos 1950 e 1960. Os cerca de cem filmes produzidos apresentavam uma física menos abstrata, com os experimentos complexos de laboratório explicados pelos maiores nomes da área na época. A estratégia foi exportada para vários países do mundo incluindo o Brasil, com o apoio do MEC.

Na Rússia pré-revolucionária, ainda no século XIX, o cinema também fora incorporado à pesquisa científica para o desenvolvimento tecnológico e para o suporte no ensino. A microcinematografia, o time-lapse, o raio-x, entre outras técnicas, já haviam sido empregadas com êxito de modo análogo ao europeu. O almirante Makarov usou uma câmera de cinema para registrar o teste do navio quebra-gelo Ermak. Graças à análise quadro a quadro, foi possível calcular a pressão do gelo na superfície do casco do navio. O pioneiro da aviação russa N. E. Zukovskij usou a câmera para estudar aerodinâmica e dinâmica de fluidos. Assim como Marakov e Zukovskij, muitos outros empreenderam pesquisa científica munidos de câmeras de cinema.

Um artigo interessante a respeito desta produção é "Legitimité scientifique et pédagogique du cinéma de 'vulgarization scientifique' en Union Soviétique" (2018). Nele, a autora Irina Tcherneva se debruça sobre os anos de 1930 a 1970, em que os filmes utilitários formavam grande parcela da cinematografia científica ou de ensino, ou seja, filmes que cumprem demandas estatais de educação política e ideológica. Ela identifica as oscilações entre orientações governamentais em relação ao que deveria ou não ser produzido, conforme a sucessão dos governos soviéticos, e localiza o descompasso entre a produção de filmes para grande público e os filmes para formação técnica, promoção industrial e educação geral. O termo "educativo" era designado à educação política.

Depois da revolução russa, o cinema ganhou importância como o veículo de informação sobre saúde, geografia, riquezas naturais, entre outros temas de interesse geral, e integrou-se ao esforço para reconstruir a nação. A partir das décadas de 1920 e 1930, com o processo de industrialização em andamento acelerado, muitos filmes foram realizados com o intuito de oferecer educação técnica e instrução para um enorme contingente que se tornaria mão de obra operária. O que se convencionou chamar cinema científico na União Soviética abarcou uma grande variedade de temas, como 
biologia, química, história da arte, antropologia, geografia, filmes técnicos e industriais, e atendiam sempre à demanda das administrações centrais e dos ministérios.

Após a segunda guerra mundial, o Partido Comunista liderado por Josef Stalin decretou a obrigatoriedade de se produzir ao menos 35 filmes de difusão científica por ano. Este número aumentou para cinquenta em 1950. Mas o partido constatou que tais produções de "difusão científica" não atendiam aos objetivos propagandísticos das aquisições tecnológicas soviéticas (TCHERNEVA, 2018, p. 53). Havia uma permanente tensão entre as ordens vindas dos ministérios, às vezes rivais (por exemplo, o Ministério da Cultura e o da Indústria), e entre os diferentes comitês, com interesses muitas vezes conflitantes. Para o Partido Comunista, um filme estritamente científico teria também a incumbência de divulgar as conquistas soviéticas.

Outro exemplo de conflito entre as prioridades científicas, as ordens políticas e o livre arbítrio dos cineastas foi o projeto do filme $A$ idade do ferro (1957). Um geólogo propôs a realização do documentário sobre os minerais que "tiveram um papel decisivo na cultura material da humanidade" (TCHERNEVA, 2018, p. 57). Escreveu-se o roteiro já adequado à agenda das políticas industriais, focado na tecnologia de extração de metais e nas jazidas. Os consultores científicos ajustaram o script ainda mais às orientações políticas, tomando o cuidado para manter a argumentação científica. Surgiu a ideia de uma sequência que tratava da história do metal a partir da produção de armas, o que gerou uma discussão em torno da função pacifista das armas, já que elas também foram utilizadas em guerras pela independência dos povos. Ao final, o filme se posicionou entre o tema da política industrial e o tema da paz, ainda assim fazendo parte do gênero "divulgação científica".

Entre 1958 e 1962, o realizador e microbiólogo Aleksandr Zgouridi foi vicepresidente da Associação Internacional do Cinema Científico (AICS), sendo responsável pelo intercâmbio com filmes científicos europeus. Em 1958, a revista Iskusstvo Kino dedicou um número ao cinema científico europeu, a propósito do congresso internacional da AICS, em que filmes de Jean Painlevé e de Virgilio Tosi foram apresentados. Entre os soviéticos, dois aspectos foram ressaltados: o uso do cinema como método de análise científica e no circuito escolar. Quanto aos filmes de Painlevé e Tosi, foram considerados excessivamente centrados nas informações científicas, o que colocava em risco a dimensão educativa e de propaganda tecnológica. Filmes de microscopia sobre o processo de cristalização da água eram vistos como belos 
espetáculos, embora flertassem com "experiências meramente especulativas e abstratas" (TCHERNEVA, 2018, p. 59).

Entre os anos de 1960 e 1970, filmes como O que é a Teoria da Relatividade (1961), Curso de Física às 20:30 (1971) e O matemático e o diabo (1972) visaram um público maior e adotaram uma forma ficcional e humorística para tratar os temas científicos. O filme Janela para o mundo (1969) inscreve-se no conceito de filme de ciência popular ao mostrar as realizações da ciência soviética no campo da ótica, da microcinematografia e da astronomia, permitindo ao cidadão comum ver o invisível e testemunhar os segredos da natureza e do universo (figs. 42 a 44).


Figuras 42, 43 e 44: Cenas de Janela para o mundo (1969), filme com imagens da vida cotidiana, da natureza e de laboratórios que relacionam as descobertas tecnológicas com a vida do cidadão comum, traduzindo em imagens as "conclusões científicas com eloquência e de modo cativante” (TCHERNEVA, 2018, p. 59).

De todo modo, na antiga União Soviética, não havia uma concepção precisa da abrangência da expressão "cinema científico" para além da função didática e da promoção industrial ligada a interesses de propaganda política, talvez por herança de uma visão stalinista. Diferentemente da produção norte-americana, em que os objetivos de cada filme eram bem delineados, na União Soviética, a produção do cinema científico era menos organizada, uma vez que deveria traduzir e atender a diferentes agendas.

Em diversos países, incluindo o Brasil, o cinema científico e o filme de pesquisa foram desenvolvidos sobretudo em algumas universidades, muitas vezes em colaboração com algum órgão estatal, visando a divulgação dos trabalhos de pesquisadores e o intercâmbio entre instituições congêneres. No Brasil, o Instituto Nacional do Cinema Educativo (INCE), investiu nesse sentido por esforço de seu fundador Edgard Roquette-Pinto. Os colaboradores mais assíduos do INCE foram Humberto Mauro e B. J. Duarte. No escopo científico, o tema saúde era o mais frequente, tanto na obra de Mauro como na de Duarte, com filmes destinados a 
estudantes e a congressos de medicina, com demonstrações de cirurgias, usos de equipamentos, formas de esterilização e diagnóstico e prevenção de doenças. Mas há também filmes fora do campo da medicina, como Photographias intermitentes do reino vegetal (1936), Lapidação de diamante e Serpentes do Brasil (1941) (figs. 45 a 53).
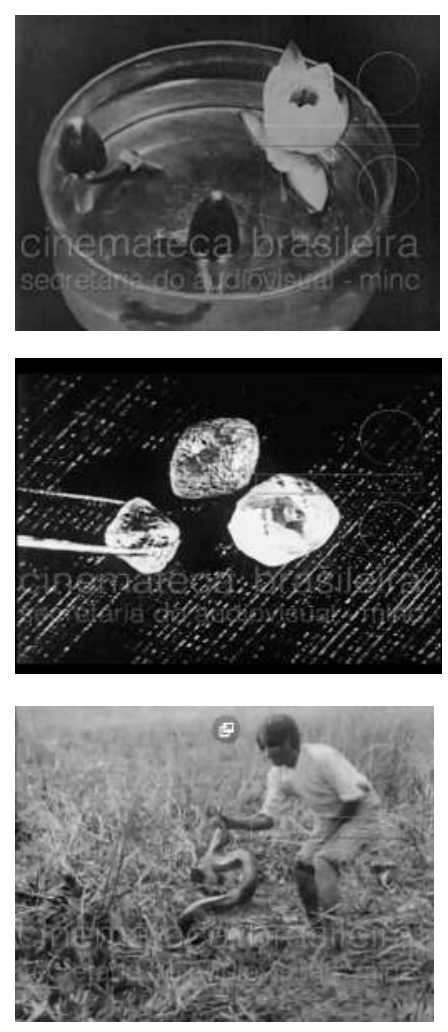
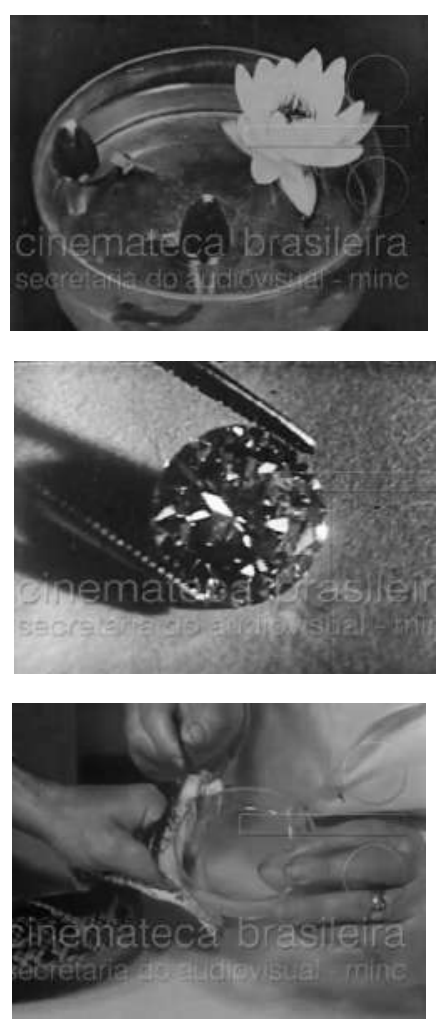
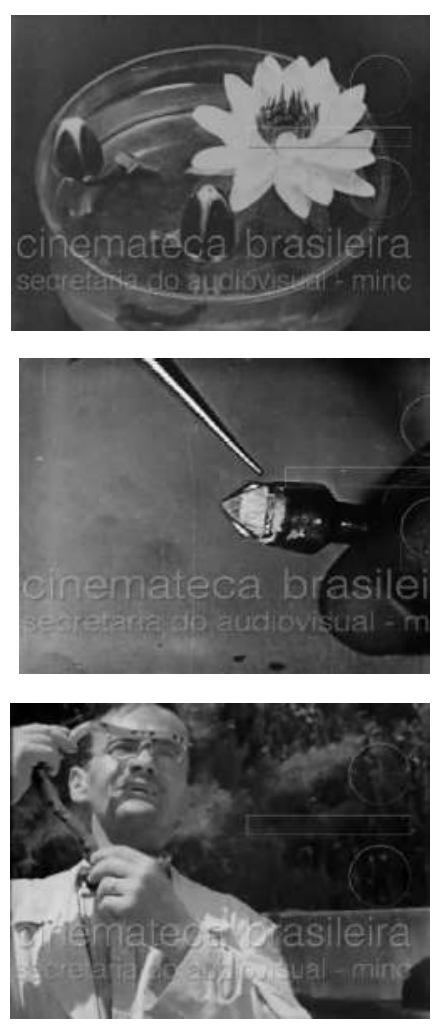

Figuras 45 a 53: Imagens extraídas dos filmes Photographias Intermitentes do Reino Vegetal (figs. 45,46 e 47), Lapidação de Diamante (figs. 48. 49 e 50) e Serpentes do Brasil (figs. 51, 52 e 53). Apenas o último, dirigido por Alexandre Wulfes, é sonorizado. ${ }^{20}$

Entre as décadas de 1930 e 1960, Mauro produziu 357 documentários, 97 deles sobre o tema saúde. A pesquisadora Alice Ferry, da Fiocruz, debruçou-se sobre a obra de Mauro e constatou que, entre os filmes de saúde, seria possível estabelecer quatro categorias, conforme as fichas técnicas, o momento histórico e o conteúdo: institucionais, difusão científica, educação rural e ensino e pesquisa.

Os institucionais faziam propaganda das ações do Ministério da Educação e Saúde, ao qual o INCE era subordinado. Em geral eram documentários, por exemplo, sobre a produção da vacina contra a febre amarela pela fundação Rockfeller (que funcionava no Instituto Oswaldo Cruz). Os filmes de difusão científica eram rodados

\footnotetext{
${ }^{20}$ Os filmes aqui citados foram consultado no Banco de Conteúdos Culturais da Cinemateca Brasileira, em: <http://www.bcc.org.br/filmes $>$.
} 
em 35 milímetros, exibidos nos cinemas e tinham como temas alimentação, puericultura, indústria oftálmica, músculos do corpo humano.

Os filmes de educação rural, rodados nos anos 1950 para uma campanha nacional, contavam com a coprodução da United States Agency for International Developement, e tinham como tema principal a saúde do homem do campo, a alimentação, a utilização de fossas sanitárias, o consumo de água potável, entre outros. Assim surgiu a série Campanha Nacional de Educação Rural, com a produção de Higiene rural, A água e sua captação, ambos de 1954, e O preparo e conservação de alimentos, de 1955.

Os filmes de ensino e pesquisa foram indicados para alunos do ensino superior e traziam como temas descobertas e experimentos, como técnicas de esterilização, saúde da mulher, cirurgias e tratamentos de saúde. Vários desses filmes eram silenciosos para que o palestrante ou o professor pudesse fazer comentários durante a exibição. Exemplos desta produção são Sistematização da colpomicroscopia (1953) e Hipospádia neuretroplastia (1964), uma cirurgia peniana. São filmes que retratam procedimentos invasivos nos genitais feminino e masculino respectivamente, e que guardam na miseen-scène uma certa frieza na manipulação e demonstração dos órgãos.

No Brasil, a projeção de filmes em sala de aula também respondia a uma reivindicação por reformulações no sistema de ensino, algo que já ocorria desde a década de 1920, com o investimento no cinema como instrumento pedagógico (semelhante ao que aconteceu na Europa).

Vale notar que a função de fazer propaganda era inicialmente uma atribuição do Departamento de Imprensa e Propaganda (DIP). Entretanto, o trabalho inventivo do cineasta no INCE (subordinado ao Ministério da Educação e Saúde) rendeu-lhe a posição de diretor das propagandas no setor da saúde pública.

Depois de Mauro, B. J. Duarte foi quem mais produziu filmes científicos. Entre 1939 e 1974, Bejota, como é mais comumente chamado, produziu cerca de seiscentos filmes, dos quais 192 estão na Cinemateca, muitos premiados dentro e fora do país. Grande parte de seu trabalho relaciona-se com a cidade de São Paulo, seus espaços, sua história, a ciência e a medicina.

Brasileiro nascido em Franca, Bejota passou parte da infância e da adolescência na França, entre 1922 e 1929, onde morou com um tio fotógrafo e teve oportunidade de aprender e aperfeiçoar a técnica da fotografia, além de ter contato com intelectuais e artistas. De volta ao Brasil, tornou-se um excelente retratista, trabalhou na imprensa 
como fotojornalista e foi crítico de cinema, ensaísta, produtor, e se envolveu com a fundação do Clube de Cinema de São Paulo, da Cinemateca Brasileira, e do Foto-Cine Clube Bandeirante. Desde a infância teve interesse pela medicina, mas a necessidade de se sustentar levou-o a estudar direito, curso de meio período que lhe permitia estudar e trabalhar.

Sua filmografia compreende mais de 500 filmes, dos quais cerca de metade são voltados para a ciência. Grande parte dessa obra se perdeu ou está danificada, havendo poucos filmes de ciência entre os que sobraram.

Um de seus maiores feitos foi o registro do primeiro transplante de coração humano do Brasil. Transplante cardíaco (1968) foi realizado no Hospital das Clínicas com direção científica do dr. E. J. Zerbini. A importância do evento já se denotava no início grandiloquente do filme, com uma vista aérea de São Paulo, enquanto o narrador enfatizava o desenvolvimento avançado da metrópole. Na sequência, a câmera localiza o Hospital das Clínicas da Universidade de São Paulo. A primeira cartela do filme avisa: "Demonstração da técnica cirúrgica do transplante cardíaco realizada em cadáver". O espectador poderia portanto assistir às cenas que viriam com um certo alívio de saber que não haveria risco de vida no procedimento (figs. 54 a 56). Bejota posicionou a câmera praticamente no local onde estaria a cabeça do cirurgião, sua subjetiva, oferecendo ao espectador a mehor visão possível da operação. A cada procedimento, a voz do narrador explicava o que estava sendo feito, em meio aos recursos tecnológicos mais avançados disponíveis.
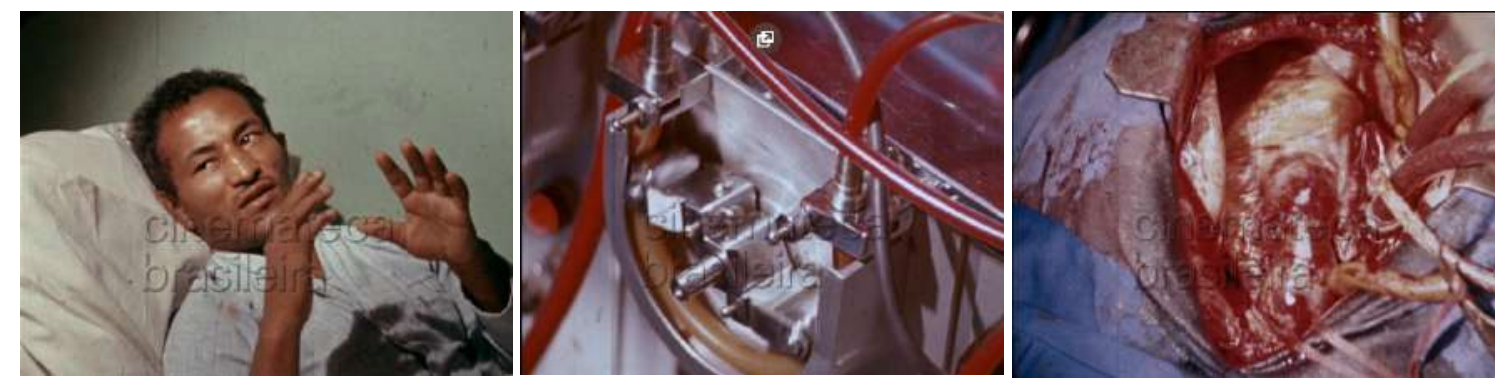

Figura 54, 55 e 56: Cenas de Transplante cardiaco. Na primeira imagem (54), o paciente J. F. C. antes de receber o novo coração conversa com a equipe. Um homem simples do Mato Grosso com um quadro de anomalia congênita é submetido a um procedimento no hospital mais bem equipado do país. Na terceira imagem (56), vê-se sua cavidade toráxica sem seu coração.

Ao final da cirurgia com o cadáver, Bejota apresentava o paciente necessitado do novo coração, trazendo um pouco da rotina do pronto-socorro, onde um paciente com sérios ferimentos dava entrada, mas conseguia sobreviver. Outro paciente com 
morte cerebral foi monitorado para que se pudesse extrair seu coração. Bejota construiu assim uma narrativa científico-documental emocionante, com momentos de tensão e de êxito, culminando com a cena em que o coração transplantado voltaria a bater no coração do receptor. A percepção visual, a expertise em informação técnica e conceitual, o comprometimento com a inteligibilidade sem perder o refinamento estético são traços marcantes, especialmente nos filmes científicos de Bejota.

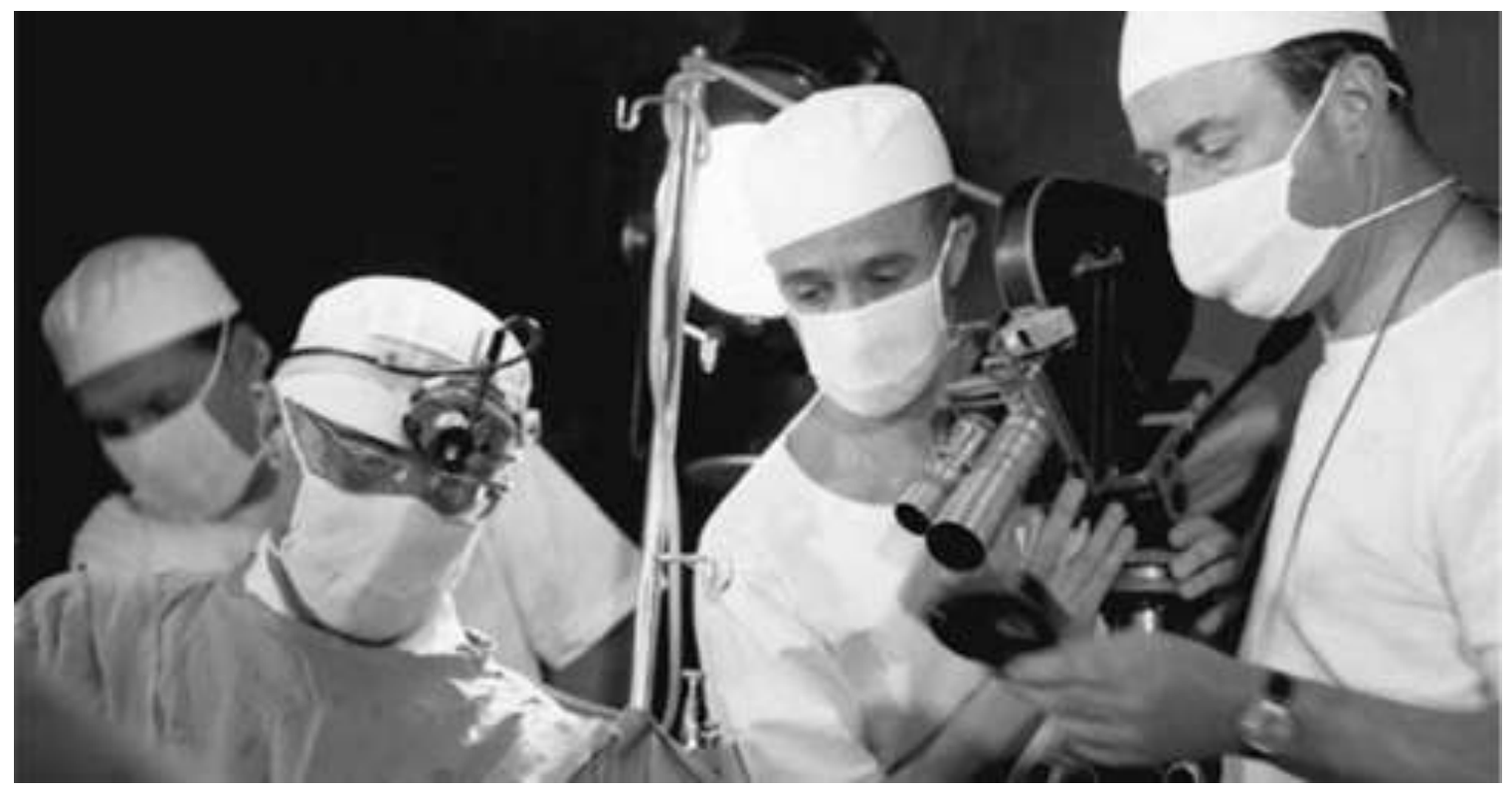

B.J. Duarte na câmera com o Dr. Euryclides Zerbini filma Transplante cardíaco. 


\section{Capítulo II}

\section{Poéticas e práticas no cinema científico - comunicação do sensível}

Neste capítulo, observaremos que o cinema científico pode explorar o potencial da linguagem cinematográfica como forma de conhecimento intertextual, e também veremos a maneira como as vanguardas e o surrealismo apropriaram-se das imagens científicas como fonte de criação. A partir de artigos em periódicos do início do século $\mathrm{XX}$, buscamos compreender a inserção do cinema científico no quadro da recepção popular, da crítica especializada e da reflexão em torno da construção de conhecimento sob um olhar poético. Comentamos alguns filmes que recusam um discurso científico calcado na obviedade e no excesso de explicações, mas que dialogam com o espectador estimulando o sentido pelo conjunto de percepções, de modo a intensificar a experiência audiovisual. Jean Painlevé, Roman Kroitor e Sozo Okada, entre tantos outros, são os realizadores escolhidos aqui para ilustrar essa proposta de realização que abrange toda potencialidade do cinema na construção de um discurso visual a valorizar a beleza intrínseca dos fenômenos científicos, colocando à prova as convicções e permitindo o prazer da descoberta.

$\mathrm{O}$ cinema científico parece ser aceito como um cinema menor, frio, ligado à matéria objetiva, sério, "vergonhoso" de si mesmo. Tem a reputação de "chato", desumanizado, desvinculado com o fato de ser a obra de um autor. Não é exagero supor que tal reputação se deva em parte à observação de filmes ditos pedagógicos, ou educativos, cada qual com suas características, em que o tratamento da linguagem cinematográfica não colabora para manter o engajamento do espectador. Mas há também uma consciência generalizada segundo a qual o cinema para ensino não é o verdadeiro cinema, e sim um veículo que transmite informações de um modo mais ou menos enfadonho.

A complexidade instaura-se à medida que aparecem questões que o cientistacomunicador pode entender como cruciais em sua exposição, e que apresentadas ao público errado não fazem sentido. Conforme a plateia a que se destinava, Jean Painlevé costumava ter mais de uma versão do mesmo filme, por vezes até três, modificando a montagem, a sonorização, o grau de aprofundamento em determinado tema. Como um produto de criação e de comunicação, o esperado é que encontre algum eco na plateia alvo, seja ela a comunidade científica, escolar ou o grande público. 
Se pensarmos que o cinema científico é a interface entre o modo de pensamento formal científico, relativamente universal (cientistas do mundo seguem noções básicas de procedimento), e um determinado público, seria possível propor um cinema que seja ao mesmo tempo rigoroso e cativante? A delimitação do campo "filme científico", como já foi exposto, abrange todo o filme feito a serviço da ciência, em que o expediente principal seja obedecer aos critérios rigorosos do método científico e à especificidade do cinema. Assim, em muitos casos, apenas mostrar o fenômeno não é suficiente: é necessário expor os procedimentos empregados e estabelecer com o público a cumplicidade, sem subestimar sua inteligência. Partir de um ponto conhecido para, em seguida, revelar o novo.

Não há unidade nos filmes que falam de ciência. A própria multiplicidade temática e metodológica impede o olhar unificado. O que se espera desses filmes é que ensejem alguma reação do público, seja o debate, seja o prazer, seja alimentar a curiosidade e informar. Esta preocupação com o que existe e com o que pode vir a existir, uma prontidão para achar tudo estranho e singular são sintetizados, para Michel Foucault (1980), na palavra curiosidade. Esta, inerente aos filmes narrativos, traz em si a questão: “O que vem depois?” (GAYCKEN, 2015, p. 3). Imagem após imagem, o espectador é convidado a entrar em um universo estranho ao seu, com regras e códigos próprios, exposto de modo a dar visibilidade a aspectos peculiares da realidade.

Durante a pesquisa de doutorado sanduíche na Universté Sorbonne Paris 3, esta autora pôde constatar dezenas de artigos sobre o cinema científico nos periódicos da base de dados da Cinemateca Francesa. Foram escolhidos os publicados em revistas genéricas de cinema, não apenas as que tratam exclusivamente do cinema científico. São textos voltados para um público maior e de alguma forma buscam analogias com a contemporaneidade, a estabelecer uma ponte entre o cinema, a ciência, a arte e a vida.

Assim, o artigo de Lucienne Escoube publicado na Cinémagazine (1928) comenta o sucesso de uma difícil empreitada, a filmagem dos glóbulos brancos de um invertebrado in vitro. A estrutura do texto ampara-se nos pilares do cinema e do ensino: o cinema não serve apenas para passar horas agradáveis, mas é também instrumento de pesquisa; contextualiza a demanda do laboratório e as condições delicadas de filmagem; comenta o êxito da experiência, face ao encantamento que pode causar ao espectador; desvenda o encantamento e volta à realidade do laboratório. "Este espetáculo notável não demanda nenhuma especialização científica para se fazer sentir. Basta abrir os olhos, olhar e se impressionar - e uso esta palavra em toda sua força primitiva" 
(ESCOUBE, 1928, p. 156). Escoube (1928, p. 156) descreve a aparência e o comportamento da célula, seus grânulos internos e os tentáculos sinuosos, que ela projeta e retira sem parar "como uma dançarina perturbada que, alternadamente lança e recolhe seus véus". É curioso que o autor remeta à imagem da dança para descrever uma célula microscópica, algo que sugere um espetáculo hipnótico com um certo padrão, mas com surpresas, sem início nem fim. Remete também à Serpentine dance (1899), o filme da dançarina Loie Fuller performando seu balé enquanto seu vestido muda de cor. "A que feiticeira se devem esses encantos? Simplesmente aos movimentos dos ambócitos dos invertebrados" (ESCOUBE, 1928, p. 156). Este cientista é obcecado e as imagens alimentam seu banco de dados e sua imaginação simultaneamente. A descrição de Escoube é precisa, repleta de comparações com imagens comuns, mas também fantasiosas; é um convite para que o público de cinema aprecie e se interesse pelo mundo de dentro dos laboratórios. A natureza excede o homem naquilo que ela tem de extraordinário e o transcende.

Em outras palavras, o cinema em si, ao deformar o espaço (na maximização da tela) e o tempo (nas altas velocidades ou câmeras lentas), introduz no espectador à instabilidade via elemento surpresa. Dado que o registro mecânico é ainda percebido como um registro do real, a incongruência se instala e o espectador é desafiado, face a face com um quebra-cabeças que necessita da sua participação ativa. É esse o charme do espetáculo cinematográfico e do seu poder de fascinação que saltou aos olhos das vanguardas europeias e dos surealistas (figs. 57 a 59).
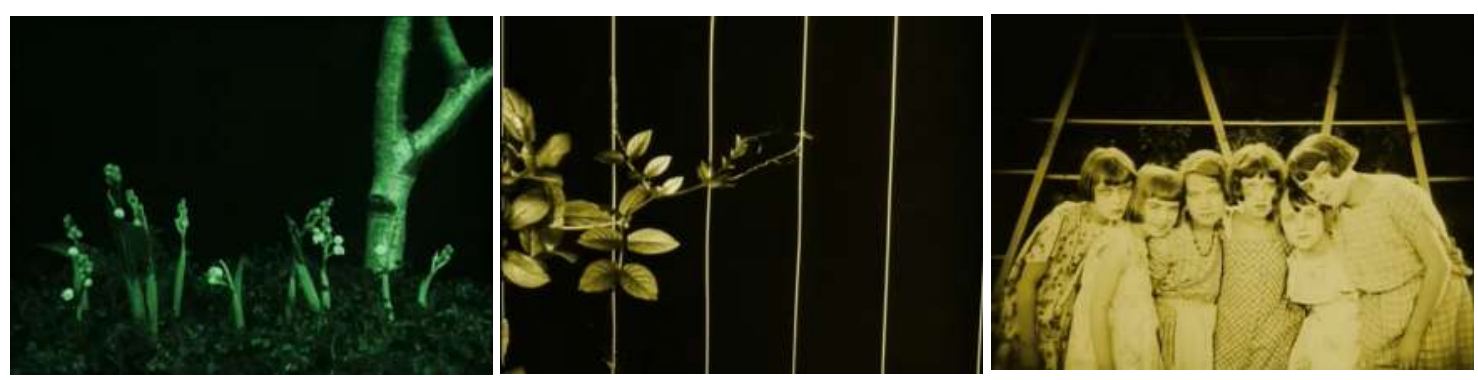

Figuras 57, 58 e 59 : Cenas de Das Blumenwunder [O milagre das flores], de Max Reichemann. No filme, um grupo de crianças brinca no jardim e se encanta com o crescimento das plantas e flores em time-lapse. Uma fada guardiã das flores adverte: "agora, olhem aqui seus olhos ficarão encantados com o conceito de tempo". Realizado entre 1921 e 1925, O milagre das flores conta com as filmagens da companhia Basf para uma campanha publicitária de fertilizantes. A trilha sonora reforça o encantamento diante da vida em movimento das plantas. 
Quando filmou L'Âge d'or, Luis Buñuel queria iniciar o filme com uma cena em que o escorpião se suicida quando se encontra no centro de um círculo de fogo. Tentou realizar a cena diversas vezes, sem sucesso, já que esse comportamento mítico do escorpião não acontece na vida real. Buñuel procurou, então, imagens de arquivo de escorpiões e encontrou Le Scorpion languedocien, feito pela Éclair em 1913, que constava no catálogo como filme de ciência. L'Âge d'or e Das Blumenwunder são exemplos da circulação das imagens científicas fora de seu circuito habitual. Na efervescência criativa do entreguerras, época de um cinema anticonformista, a avantgarde explora os procedimentos do imaginário científico para obter efeitos oníricos, característicos da tendência surrealista. Hans Richter, Jean Epstein, Marcel Duchamp, Marcel L'Herbier, Louis Delluc, Germaine Dulac, entre outros, foram capturados pela visão do novo que esse cinema oferece. René Clair exclama: "A barbárie maravilhosa dessa arte me encanta. Enfim, terra virgem!" (CLAIR apud SCHMIDT; DÉRIAZ, 2010, p. 71).

\section{O valor do cinema desencadeado pela visão do movimento}

O filme científico, antes de mais nada, é cinema e é criação. Sua força reside na forma de ver/mostrar um assunto de um ângulo imprevisto na busca por respostas convincentes seja qual for seu público. É um cinema que "compartilha a mesma tela que o cinema espetáculo-arte, a mesma aventura na qual o espírito do homem queima como uma chama", nas palavras de Louis Delluc, citado por Jean Rouche (1986, p. 14, tradução nossa), em artigo para a revista Cinémaction $n^{\circ} 38$.

Henri Langlois já percebera o poder de encantamento das imagens obtidas nos laboratórios e admirava as fotografias de Marey. A primeira exposição dedicada a sua obra foi organizada pela Cinemateca Francesa em 1963. Na ocasião, Langlois (apud MANNONI, 2005, p. 6) comentou que Marey era "um dos maiores poetas da imagem, cujos brancos, pretos e cinzas tinham a 'beleza das bordas gregas', os mais belos que podiam existir". Ele reconheceu no trabalho de Marey uma qualidade que extrapola a simples observação de um fenômeno em andamento, porque mostra aspectos da vida que passam ao largo da percepção cotidiana, frequentemente neutralizada em função do excesso de estímulos a cada instante. Lá ele viu a pausa no tempo.

André Bazin também se surpreendeu com a beleza dos trabalhos de Marey e Muybridge. Para ele, quando Muybridge e Marey realizaram seus trabalhos de 
investigação científica, não apenas criaram a técnica do cinema, mas ao mesmo tempo a estética pura do cinema. Bazin descobriu o cinema científico em um festival em 1947, no Museu do Homem. Aquele teria sido o mais belo festival do ano, em que "os micróbios vistos pelos microscópios são os melhores atores do mundo" (BAZIN, 2019, p. 335). As experiências com camundongos e rãs, o "amor dos micróbios" e a luta dos glóbulos brancos contra as bactérias são tão apaixonantes quanto as narrativas dos grandes filmes, e dão uma ideia das possibilidades plásticas e dramáticas deste gênero de cinema. A graça sobrenatural do cinema científico é, para Bazin, quase inconcebível de se encontrar no cinema de ficção. Os surrealistas do início do século XX, sempre em busca das imagens mais recônditas, pressentiram que a câmera apontada para a ciência era uma usina de drama, poesia, delírio e, enfim, de beleza suprema.

Além da manipulação do tempo sob a forma das distorções, a montagem (mesmo sem alteração temporal) cumpre seu papel na promoção das elipses temporais, da imposição do ritmo, que pode se dar pelo recurso de subdivisão das cenas em planos de diferentes ângulos, oferecendo pontos de vista variados e que, ante a percepção do espectador, aceleram o andamento da cena. Marey atentou para a questão da compatibilidade temporal do registro em relação às medidas e à sequência de experimentos, e sempre tomou o cuidado de introduzir em quadro um cronômetro de precisão (figs. 60 e 61). A manipulação do tempo visível no cinema científico dá credibilidade e faz a ancoragem do espectador com o mundo concreto.

O cinema é a inteligência entrelaçada com a imaginação, ele reside na apropriação do instrumental técnico em função de uma hipótese ou de um conceito. A materialização do imaginado, agora visível e comunicável, retroalimenta novas propostas/demandas/caminhos na construção de conhecimento.
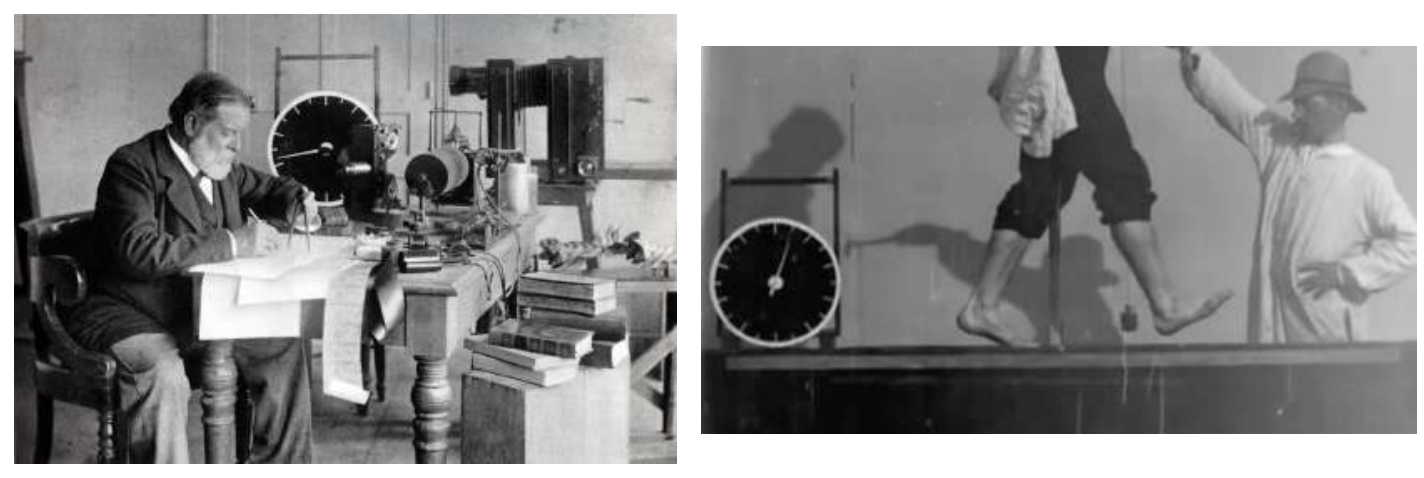

Figuras 60 e 61: Marey em seu laboratório cheio de inventos, em 1900, em fotografia de Eberhard J. Wormer (60) (TOSI, 2005, p. 82). Ao lado, registro do tempo durante a captação da série de marcha (61) (TOSI, 2005, p. 122). 
O imenso volume de textos que pensam o cinema, desde a primeira projeção até a década de 1920, atesta a força do impacto desta nova forma de olhar para o mundo em que a descontinuidade, o fragmento, integra-se diante do espectador como um feitiço. Tais textos permitem depreender como a percepção do espectador era afetada por um conjunto de gestos e ritmos dados por mudanças de enquadramento, sobreposições de imagem e todas as formas de manipulação do tempo e do espaço. A sensibilidade cinematográfica foi sendo moldada gradualmente por novas impressões, jamais experimentadas por qualquer uma das outras artes individualmente. $\mathrm{Na}$ primeiras década do século XX, período de estabilização do cinema como entretenimento popular, os códigos visuais construiam-se e se definiam no imaginário, estabelecendo essa nova linguagem.

Por outro lado, questionava-se também o valor do cinema como arte, já que derivava de procedimentos técnicos de captura automatizada da imagem. Como se posiciona o humano? "Se a literatura é a arte das sensações escritas; a escultura, arte das formas; a pintura, arte das cores; a dança, da harmonia dos gestos; a música, dos sons; a arquitetura, arte das proporções; qual seria a matéria bruta do cinema?” (DULAC, 1927, p. 31).

Germaine Dulac, realizadora e pensadora do cinema (tinha formação em música), traz uma das chaves para a compreensão do cinema-ciência como estímulo de um processo psicológico desencadeado pela visão do movimento, em que o deslocamento de formas e linhas "suscita a emoção e aciona um senso paralelo ao senso literário musical, escultural, pictórico" (DULAC, 1927, p. ?, tradução nossa). O cinema teria como função fazer o espectador aprender a ver. "Um aparelho mecânico promotor de formas expressivas e de sensações novas e latentes, [...] que convoca uma inteligência maleável, um sentimento que brota espontaneamente a partir do ritmo de uma imagem que se move, e da cadência das justaposições" (DULAC, 1927, p. 32).

O balé das formas e cores sem palavras convoca o que Roland Barthes (1982) chama de sentido obtuso, libera a imaginação e joga com o incerto. Quando as imagens por si só interrogam, elas retém o olhar, favorecem a atenção e o engajamento do espectador. Imagens que fogem do óbvio e fornecem apenas sugestões podem instigar e excitam o olhar do espectador.

No terreno científico, o cinema pretende fazer o espectador aprender a ver. Há portanto, uma lógica psicológica emotiva e rítmica. No processo interpretativo, o espectador torna-se ator na construção do significado. A obra cinematográfica é 
polissêmica por natureza, ela não apenas veicula uma informação, mas busca proporcionar uma forma de prazer estético relacionado ao conteúdo objetivo. A explicitação do método traz credibilidade, mas pode comprometer a imersão, a entrega. Seria análogo à quebra da quarta parede, uma revelação, o olhar para a lente da câmera que desperta o espectador para a materialidade fílmica e solicita a sua presença.

O filme de pesquisa científica pode tirar partido de surpresas e incitar a curiosidade, apesar da precisão de que é creditado. O cineasta-cientista ajusta seu conhecimento sobre o fenômeno às técnicas que empregará na filmagem. Ele equilibra a duração dos planos e os raccords de movimento na montagem; com isso, faz parecer que algo aconteceu em uma só tomada. Todos os recursos da arte cinematográfica intervém para a harmonia do filme (UEBERSHLAG, 2010, p. 106) respeitando os preceitos teóricos que representam, materializam. Individualmente, cada plano exprime uma verdade que, após a montagem, deve expressar a essência conceitual por meio da emulação de um evento visto em sequência.

Ao conjugar a percepção emocional com o estado racional, cria-se a possibilidade para que a compreensão exceda o campo do visível e que as descobertas extrapolem as aparências. A “percepção excede o estado de olho ordinário para alcançar uma visão exata, lúcida, aberta a uma nova inteligência das coisas", argumenta a pesquisadora Josette Ueberschlag (2010, p. 107). É nesta faixa de fronteira, entre o emocional e o racional, que coabitam o conotativo e o denotativo, o concreto e o abstrato, o óbvio e o obtuso, e as figuras de linguagem.

\section{A sonorização do cinema científico}

No terreno da mobilização emocional, o som é o elemento que integra o campo discursivo da narrativa. Em geral, é usado para envolver, sublinhar, intensificar, surpreender, enfim, alterar a forma como o espectador vê o filme. O som - ambiência, ruídagem e música - pode favorecer a concentração, ou seja, "limpar" o ambiente visual para ressaltar o que realmente interessa, ou reforçar uma sensação no espectador, de modo a inseri-lo na experiência. De maneira pragmática, o compositor sueco Johnny Wingstedt propôs as seguintes funções do som no cinema, conforme sua própria prática em composição de trilhas sonoras para filmes: função emotiva, informativa, descritiva, guia, temporal e retórica. 
De maneira simplificada, a função emotiva refere-se à habilidade da trilha sonora de comunicar aspectos emotivos de personagens, relacionamentos, situações ou eventos. Ela evoca a identificação emocional do espectador. A função informativa é observada quando a música expressa ou explica um contexto, por exemplo uma música de época ou uma música característica de um local. A função descritiva relaciona-se com a função informativa, mas é mais específica em relação ao objeto físico ao qual ela se refere em uma cena, por exemplo uma música cujo andamento sincroniza-se com o trote do cavalo ou com o movimento de um trem. A função guia volta-se diretamente ao espectador com o objetivo de direcionar o olhar, atrair sua atenção para algum ponto na tela. É uma função mais relacionada à publicidade e aos jogos eletrônicos. A função temporal traz a dimensão da continuidade ou interrupção de uma ação. É a função que contrubui para moldar a estrutura do fime na montagem. Finalmente, a função retórica refere-se ao modo como a música comenta a imagem, muitas vezes pelo contraste com a informação visual. Na maioria das vezes, essas funções combinam-se dinamicamente, coexistem na composição de uma determinada cena, de maneira que sempre há uma função mais saliente.

No canal auditivo também circula conhecimento, pois a vibração sonora reverbera no espectador e, por ser cinema, cumpre as mesmas funções de entretenimento. No cinema científico, os regimes de uso do som em toda a sua variedade tendem ao espectador com os objetivos de levá-lo ao lugar do cientista e convidá-lo a imaginar uma determinada situação. O som é um fenômeno que acontece no tempo e, como tal, é sujeito a essa dimensão no que diz respeito à capacidade de atenção, aos retardos na reação, algo que se relaciona com as transmissões nervosas. Logo, ele é a medida para os processos mentais (DASTON; GALISON, 2010, p. 306) envolvidos na questão da recepção das imagens do cinema.

O som não costuma ser priorizado como elemento a ser investigado nas pesquisas que usam os recursos do cinema, a menos que um dos objetivos seja a compreensão de algum aspecto sonoro dentro do fenômeno estudado. Um registro de time-lapse, por exemplo, não comporta uma gravação de som. Um registro cinematográfico em alta velocidade (em câmera lenta) já permite o registro sonoro. Muitos filmes científicos, os de pesquisa, que apenas participam de uma etapa do processo, acabam não sendo sonorizados.

É comum pensar na sonorização do filme científico apenas na etapa da finalização. A experiência de Jean Painlevé, incontornável na história do cinema e do 
cinema científico, aponta para a multiplicidade de usos do som nos mais diversos temas filmados. Em mais de cinquenta anos de atividade, Painlevé trabalhou com a música, as locuções e o silêncio de formas distintas. Seus filmes não prescindiam de sincronismo sonoro, mas a localização do áudio parece-nos sempre exata.

O filme, após revelado, fornecia os indícios objetivos para a compreensão do fenômeno. A banda sonora era tratada, então, como elemento dramático, que aproximava o espectador da cena observada, seja trazendo-a para um ambiente auditivo familiar ao espectador, seja conduzindo este ao fundo do mar, por exemplo, graças a uma sonoridade incomum, misteriosa.

Em 1929, em Hyas et Sténorinques (1929), a trilha musical é um tema de Frédéric Chopin, executada por Maurice Jaubert, ${ }^{21}$ em que a delicadeza harmônica acompanha a performance dos crustáceos que habitam entre algas e esponjas. Poder-seia pensar nas funções emotiva e temporal, conforme a proposição de Wingstedt. Os intertítulos caricaturam a performance dos animais, trazem-nos para o universo do espectador, como em "um balé à Loie Fuller", seguido das evoluções da hidra, que movimenta seus tentáculos como saias de bailarinas.

Já em seus filmes da década 1930, várias das trilhas musicais seguem um estilo de música de cinema clássico, com uma orquestra de câmara dinâmica executada ora com romantismo, ora com suspense, e mesmo com silêncios, entremeada pelas locuções. Assim acontece em L'Hippocampe e Crabes et crevettes, ambos de 1935, entre outros. Já nas décadas de 1940 e 1950, aparece a influência do jazz, com trilhas de Louis Armstrong e Duke Ellington, que tornam bem-humoradas - função retórica - as sequências da impiedosa cadeia alimentar em ação: "a morte em cólera, sem paixão, sem reflexão, sem procrastinação, sem moral, a morte necessária: por necessidade" (ASSASSINS D'EAU DOUCE, 1947, tradução nossa). Em Le Vampire (1945) e Assassins d'eau douce (1947), é interessante notar como algumas cenas parecem ter até mesmo uma sincronia entre a ação e o som - em Assassins d'eau Douce, ao solo de bateria, as patas finas do camarão movem-se frenéticas em mimese ao movimento das baquetas do baterista. A sonoridade dos filmes nos anos 1960 e 1970 já é completamente diferente, com trilhas de música concreta, eletroacústica e experimental, uma proposta abstrata, sem um tema musical melódico para embalar as imagens. Em

\footnotetext{
${ }^{21}$ Em entrevista concedida ao programa Cinéromans $7 / 10$ - Les vies de Jean Painlevé $\left(1^{\text {ère }}\right.$ diffusion: 24 aug. 1982), Jean Painlevé declara não ter gostado do arranjo musical de Maurice Jaubert. Disponível na sessão de podcasts da Radio France Culture: $<$ https://www.franceculture.fr/emissions/les-nuits-de-franceculture/xxx-rediff-occurence-3-du-jeudi-08-novembre-2018>.
} 
Les Amours de la pieuvre (1965), a trilha é composta por Pierre Henry, um dos pioneiros da eletroacústica (figs. 62 a 64).


Figuras 62, 63 e 64: A primeira imagem (62) é extraída de Hyas et Sténorinques, filme que passou no segundo Congresso do Cinema Independente em Bruxelas, em 1930, onde Sergei Eisenstein estava presente. Ao lado de filmes de Hans Richter, Man Ray, Jean Vigo e Fernand Léger, Painlevé mostra um crustáceo em delicado movimento semelhante a um balé aquático. A segunda imagem (63) mostra um dos filmes mais conhecidos de Painlevé, L'Hippocampe, que apresenta em detalhes a morfologia e o misterioso sistema reprodutivo do cavalo-marinho. $\mathrm{Na}$ terceira imagem (64), dois polvos praticam o ritual amoroso embalados por uma trilha musical de sons dissonantes e efeitos de música eletrônica que criam uma ambiência ao mesmo tempo rara e erótica.

O ambiente desconhecido do fundo do mar, onde a percepção humana do som é distorcida (em relação à percepção da propagação sonora no ar), é evocado pelos padrões sonoros dissonantes, ora reverberantes, ora com sons secos, às vezes com “brilhos". Já nos anos 1980, o tratamento do som é inteiramente diverso. Em Les Pigeons du square (1982), optou-se pelo registro naturalista do som, em que os ruídos da cidade formam uma ambiência sonora incorporada ao alarido das crianças que conversam com o sr. Painvelé em uma praça pública enquanto observam o movimento das pombas.

Vale ainda dizer que, entre 1920 e 1970, Painlevé explorou o ambiente subaquático, eventos microscópicos e cirurgias médicas, mantendo um registro de lirismo em meio às peripécias que suas lentes detectavam. Estudou na escola politécnica por influência de seu pai, mas caminhou para a medicina e para as ciências naturais, afiliando-se ao movimento anarquista, ao surrealismo e às vanguardas artísticas. Painlevé, que descobriu sua vocação para o cinema científico em 1925, ao conhecer os filmes de Jean Comandon, via este cinema como um meio de pesquisa e de difusão ao mesmo tempo. Seu rigor científico era aberto para a sensibilidade artística, e seu entusiasmo frente às mais diversas e misteriosas manifestações da vida motivou-o a adaptar e desenvolver aparatos propícios às tomadas que ele imaginava. A luta pela sobrevivência e a lei do mais forte, característicos do instinto animal, podem ser 
entendidos como uma metáfora da vida do homem em sociedade. De fato, a invasão animal no cinema de Painlevé representa um movimento de revolta, de rebelião contra a ordem. Não por acaso foi amigo próximo de Jean Vigo, o cineasta anarquista diretor de À propos de Nice 1930) e Zero de conduite (1933).

As criaturas submarinas de Painlevé capturaram a atenção dos surrealistas, inspirados na plasticidade das formas, no ritmo incomum, no inesperado, e também na sua capacidade de espelhar a existência humana nos aspectos mais ternos e mais violentos. Para Fernand Léger, seus filmes sobre a vida marinha eram o mais belo balé que podia existir. Para Marc Chagal, eram de uma riqueza plástica imcomparável. Mesmo assim, Painlevé não estava imune à censura, que solicitou a eliminação das cenas de reprodução sexual dos cavalos-marinhos em L'Hippocampe. A curiosidade legítima de Painlevé alimentava a atmosfera poética e onírica que imprimia em seus filmes.

\section{Filmes de astronomia e engenhosidade técnica}

Saindo do universo animal de Painlevé, o uso do som no cinema científico não obedece a uma regra determinada além de cumprir as funções já mencionadas. A estratégia da criação sonora é vasta. Um exemplo disso são os filmes cósmicos. Sabe-se que, no espaço, o som, onda mecânica, não se propaga. Mesmo assim, pode-se imaginar que um planeta que está distante do Sol é mais silencioso de um outro próximo. É possível estabelecer momentos de tensão em um ambiente inóspito, ou pelo contrário, sensação de harmonia e segurança. A liberdade total para o tratamento do som abre a porta para o fantástico, o impossível, a surpresa e a distância com o referencial real.

Um bom exemplo da exploração do som nesse tipo de filme é visto no curtametragem Univers (1960), dirigido por Roman Kroitor e Colin Low (figs. 65 a 70). Já no início, as imagens de uma imensa nebulosa são combinadas a uma trilha orquestral ao mesmo tempo dramática e misteriosa. O espectador acompanha o astrônomo em seu observatório, em sua rotina de trabalho. A câmera salta do espaço para uma vista aérea de uma cidade, o movimento dos carros visto de cima. Com um corte-aproximação, o realizador nos mostra em plongée o movimento das pessoas nas ruas. Em seguida, a câmera aterrissa em meio aos transeuntes e nos apresenta um veículo em movimento com um forte reflexo da luz solar. Esta é o elemento de raccord nos planos seguintes, 
em uma sequência que transporta o espectador do ambiente urbano para o isolamento de um observatório astronômico.
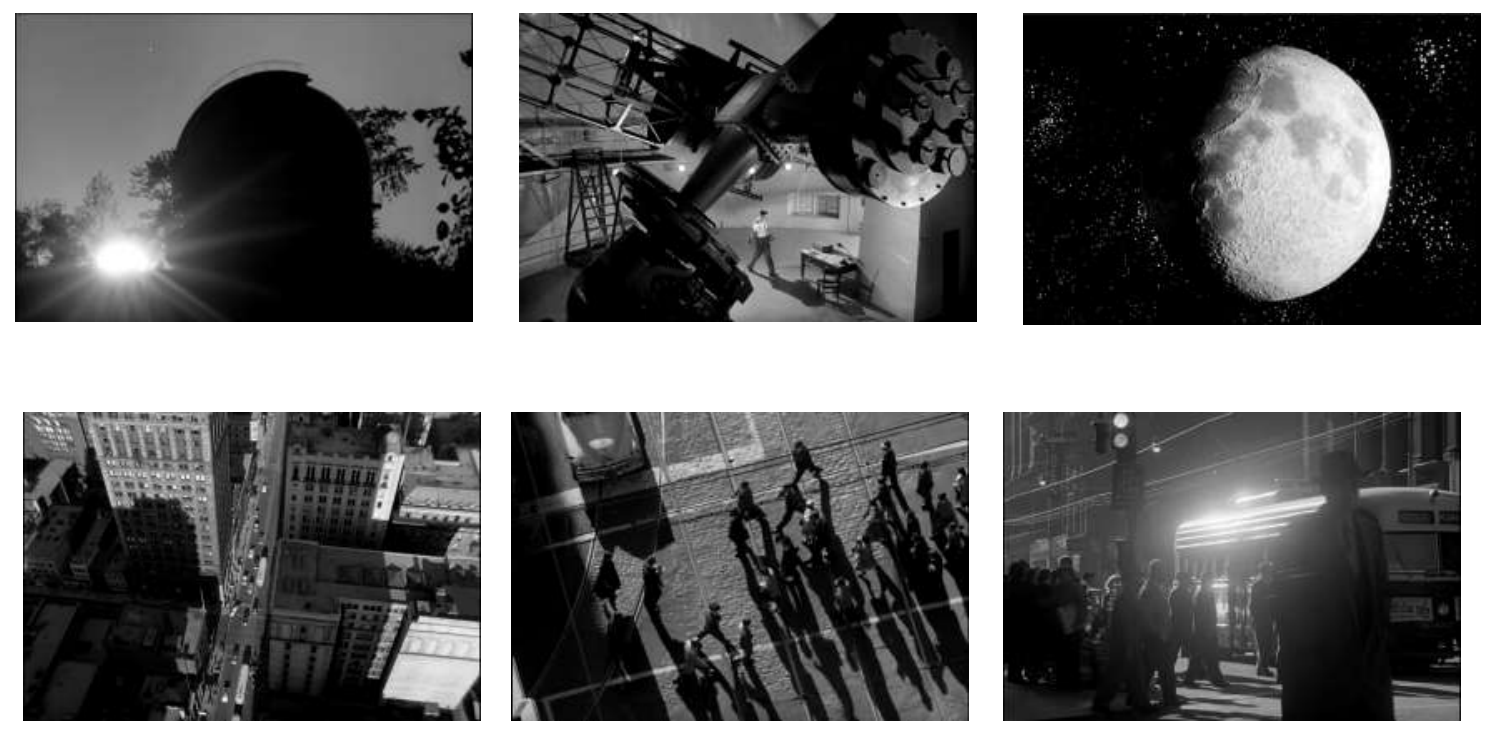

Figuras 65 a 70: Sequência de planos do filme Univers. A câmera desce até chão (65 a 67), vai para o observatório (68 e 69) e volta para o espaço (70). As sombras marcantes fazem menção a uma fonte de luz pontual, o Sol, e são um elemento visual de "costura" entre os planos, favorecem uma unidade harmônica.

Assim como em outros filmes de astronomia, há um desejo de tecer relações entre a grandiosidade cósmica com a vida em escala humana, entre o espetacular e o cotidiano. No interior do observatório, o professor-pesquisador manipula um imenso telescópio com o qual vai fazer registros de estrelas distantes. A grandiloquência da trilha sonora, épica, acompanha a complexidade da engenharia da relação homemmáquina e a estranheza - magnitude dos corpos celestes que vagam harmoniosamente na imensidão. Em Univers, mesmo os momentos explicativos e narrados são sugestivos e provocativos: são frestas para a distensão do olhar. O espectador tem tempo para apreciar e fruir, alternando a atenção para as sequências em que a informação se apresenta com objetividade.

Graças à fotografia, à animação e aos efeitos da montagem, o espectador é lançado a uma viagem pelos planetas do sistema solar, pela Lua e finalmente para as estrelas, nebulosas e galáxias mais distantes do nosso planeta. Há um trabalho de montagem meticuloso na transição entre as imagens que o astrônomo supostamente está a captar, tidas como verdadeiras, e as imagens artísticas, composições e animações em múltiplos níveis de profundidade. Univers foi uma referência para Stanley Kubrick compor seu espaço cósmico na realização de 2001 - uma odisseia no espaço (1968). 
Além de Univers, o National Film Board produziu outro filme de temática semelhante, Alouette: o primeiro satélite canadense (1963). Apesar de tratar de tema correlato a Univers, o filme restringe-se à comunicação em discurso conotativo, sem recorrer aos recursos de montagem para ir além da sucessão cronológica dos fatos, das relações de causa e consequência, ou para estabelecer relações semânticas. Alouette descreve a pesquisa, o projeto e a construção do satélite pelo Conselho de Pesquisas pela Defesa, e, em seguida, seu lançamento de uma base espacial norte-americana na Califórnia. Praticamente não há trilha musical, apenas no início e no último quarto de filme. No restante, há apenas ruídos e narração. As figuras de linguagem, metáforas, rimas visuais e as relações espaço-temporais que extrapolam a comunicação ao estilo documento/reportagem praticamente inexistem. O recurso que rompe com a formalidade sem sair do tom descritivo/didático são as cenas em animação, bem construídas e eficazes para explicar a composição das camadas da atmosfera terrestre, o trajeto do satélite e a atuação do magnetismo terrestre.

Alouette é um bom contraponto a Univers: feito no mesmo NFB, com belíssimas imagens e uma montagem bem encadeada, o filme sofre pelo excesso de rigor explicativo e pela falta de um olhar que se distancie do registro factual. Exceto ao final, quando o filme parece se render ao apelo poético: “os sinais na linguagem das estrelas são recolhidos e traduzidos pelos homens da ciência, que falam todas as línguas da Terra" (ALOUETTE, 1963), declama o narrador, fugindo do tom sério que seguiu durante todo o filme. Também é notável que, ao final, no momento do lançamento do foguete com o satélite, o filme não perde a oportunidade de explorar a tensão, trazendo o espectador para a sala de comando, onde os engenheiros exibem seus rostos preocupados com o sucesso da operação.

$\mathrm{O}$ interesse em Alouette reside prioritariamente no registro da tecnologia espacial dos anos 1960, que revela a aplicação da teoria e da matemática na manufatura do satélite, ou seja, construído praticamente à mão.

Outro exemplo de engenhosidade técnica e apuro audiovisual são os filmes da Tokyo Cinema Co., empresa criada pelo produtor de cinema Okada Sozo em 1954 com o objetivo de produzir documentários e filmes científicos direcionados para o ensino e a divulgação científica. Das centenas de filmes produzidos por Okada, grande parte atendia a demandas específicas de empresas e universidades; outra parcela era dirigida à TV, inserida na grade como entretenimento intelectual. A Tokyo Cinema Co. também contribuiu com a Encyclopaedia Cinematographica de Goettingën, realizando film- 
loops, ciclos de deslocamento animal. Além dos filmes de biologia, física e química, Okada também realizou filmes antropológicos, contando com uma equipe especializada tecnicamente e familiarizada com os procedimentos de filmagem etnográfica. ${ }^{22}$ Okada, que não era cientista, cercava-se dos melhores profissionais e de acadêmicos de ponta para produzir seus filmes, trazendo seu filho mais velho, Kazuo Okada, engenheiro, para a equipe. Em 1973, Kazuo tornou-se diretor executivo da empresa, no lugar do pai.

Em 1958, veio o reconhecinento internacional no Festival de Pádua, onde Okada Sozo recebeu o grande prêmio com o filme Mundo dos micróbios - em busca do Tubercle bacilli, filme de pesquisa encomendado pelo laboratório Chugai Pharmaceutical Co., cujo objetivo era revelar a estrutura celular do bacilo de koch, seu ciclo de vida, de proliferação e sua interação com os leucócitos. Premiado também nos festivais de Veneza, Moscou e em Londres, foi no Congresso do Filme Científico em Paris que a crítica Anne Philippe (in OKADA, 1964, p. 476) avaliou: "é um modelo de como todo filme científico deveria ser: belo, produção admirável, completamente compreensível". De fato, Mundo dos micróbios e vários outros títulos da companhia podem ser vistos como o estado da arte do cinema científico.

Okada lançou mão de todas as ferramentas cinematográficas para engajar o espectador e entregar-lhe as informações de maneira tão precisa quanto prazerosa. $\mathrm{O}$ espectador vê o aparato tecnológico no laboratório, sabe a escala de ampliação das imagens e os intervalos entre as fotografias do time-lapse. Com essas informações é possível estabelecer uma conexão das imagens com o campo cognitivo e acompanhar a linha de raciocínio, como em uma narrativa ficcional. A trilha sonora orquestrada alterna os momentos climáticos com os mais ritmados e epifânicos, pontuando a montagem com curiosidade, suspense e enigma. Um dos momentos mais excitantes é quando uma célula de defesa - o leucócito polimórfico - lança pseudópodes ao redor da bactéria - processo chamado de fagocitose. A ampliação é de quatrocentas vezes e o intervalo entre as fotografias é de três segundos, durante setenta horas.

A trilha sonora assume um tom de aventura/luta; o espectador ainda não sabe quem sairá vencedor desta batalha. Este tipo de construção de relações entre a imagem e o som, que percebemos como sincrônica, traz à memória inúmeros filmes que apelam para um jogo de plasticidade, movimento e significações de forma semelhante, entre os

${ }^{22} \mathrm{O}$ cinema etnográfico é um tipo de documentário que retrata a cultura e os costumes de grupos humanos e sociedades. É uma prática científica que encerra métodos específicos, tanto na captação de imagens como na montagem, de modo a minimizar a interferência da equipe técnica e ser preciso sem abrir mão da sensibilidade. 
quais, Fantasia, de Walt Disney (1940), é paradigmático. Novamente, a música e as imagens - inéditas e surreais - conjugam-se para acionar a adesão do espectador pela via da emotividade, não para desarmar-lhe a consciência, mas para conectá-la por inteiro.

De volta a Mundo dos micróbios, para aumentar a tensão, o microscópio amplia ainda mais a imagem. No centro da tela, outro tipo de leucócito, o monócito, que é mais lento, maior e mais potente que o polimórfico, vai atacar a bactéria. É o clímax da narrativa. A todo momento, o narrador posiciona-se entre o cientista e o espectador, traduzindo as imagens para uma linguagem mais acessível, mas com dramaticidade levada ao extremo, auxiliado pela trilha. Ele estimula a curiosidade em torno do desfecho da batalha entre as bactérias e as células defesa. A exploração de ângulos de câmera não se esgota. Até os instantes finais, ao pingar uma gota de solução salgada na lâmina onde repousa o bacilo de koch, a câmera se posiciona sob o conta-gotas, em uma tomada que evoca o espítiro de Dziga Vertov em Um homem com uma câmera (1929).
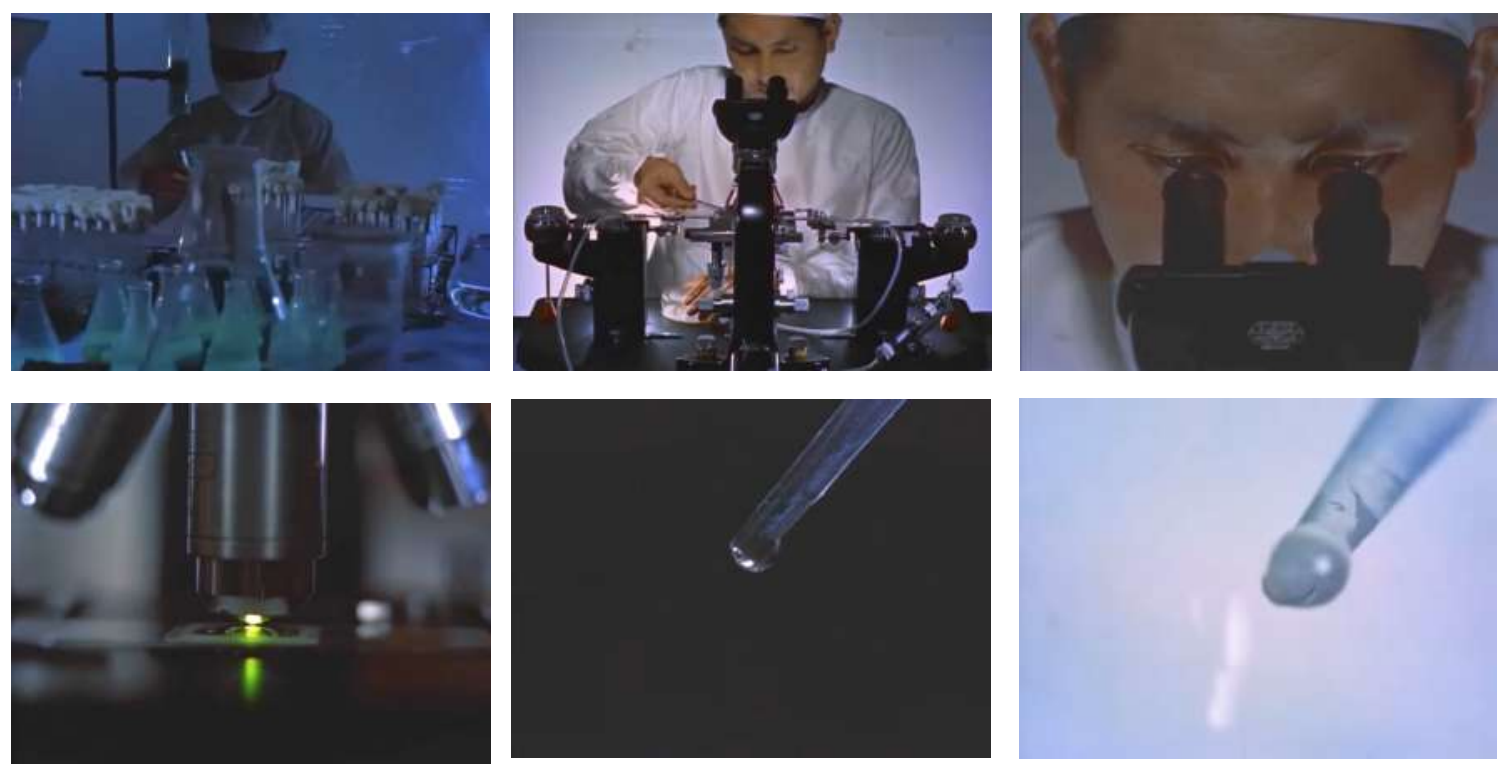

Figuras 71 a 76: Cenas de Mundo dos micróbios. Podemos ver o laboratório com iluminação azulada (71) - frieza, isolamento -, os movimentos de câmera são precisos. A figura do cientista compenetrado aponta para a precisão e o método (71 a 73). A montagem segue percurso da imagem a partir da retina do pesquisador, passando pela película, chegando à retina do espectador. As duas últimas imagens ( 75 e 76), mostram o conta-gotas, visto de lado e de baixo.

Como proposta de reflexão/imaginação, o narrador compara uma colônia de leucócitos a uma nebulosa no espaço sideral. Esse momento de distensão no filme traz em si algumas implicações relativas à noção de escala e de representação visual, promovendo um afastamento proposital em relação ao tema do filme. Ao observar 
continuamente um ponto microscópico, o cientista não deve perder de vista seu lugar e seu propósito no universo. O corpo humano como referência central, situado entre o macro e o micro, é uma imagem recorrente nos filmes científicos, usada em geral para traduzir as dimensões. Dentro de um quadro cultural mais amplo, adotar o referencial humano retoma a ideia renascentista do antropocentrismo, a partir da qual o impulso para o desenvolvimento científico e tecnológico no declínio da Idade Média se deu.

É improvável que alguma outra maneira de abordar o embate entre as bactérias e os leucócitos, por meio de aulas expositivas com ilustrações, fotografias ou mesmo da observação direta ao microscópio, seja tão contundente e ao mesmo tempo imaginativa quanto a sofisticada orquestração vista no filme. Mundo dos micróbios, A origem do óleo (1960) e Mundo dos pulsos (1962) (figs. 77 e 78), entre muitos outros da Tokyo Cinema Co., trazem o conhecimento a partir de uma questão objetiva e revelam o aparato de pesquisa, mas não deixam de lado a preocupação com a linguagem por meio da qual o conteúdo será transmitido. É um tipo de produção que usufrui integralmente do potencial do cinema como veículo de conhecimento e reflexão. Como resultado, respeitam a inteligência do espectador e entregam-lhe belíssimas e inéditas imagens.
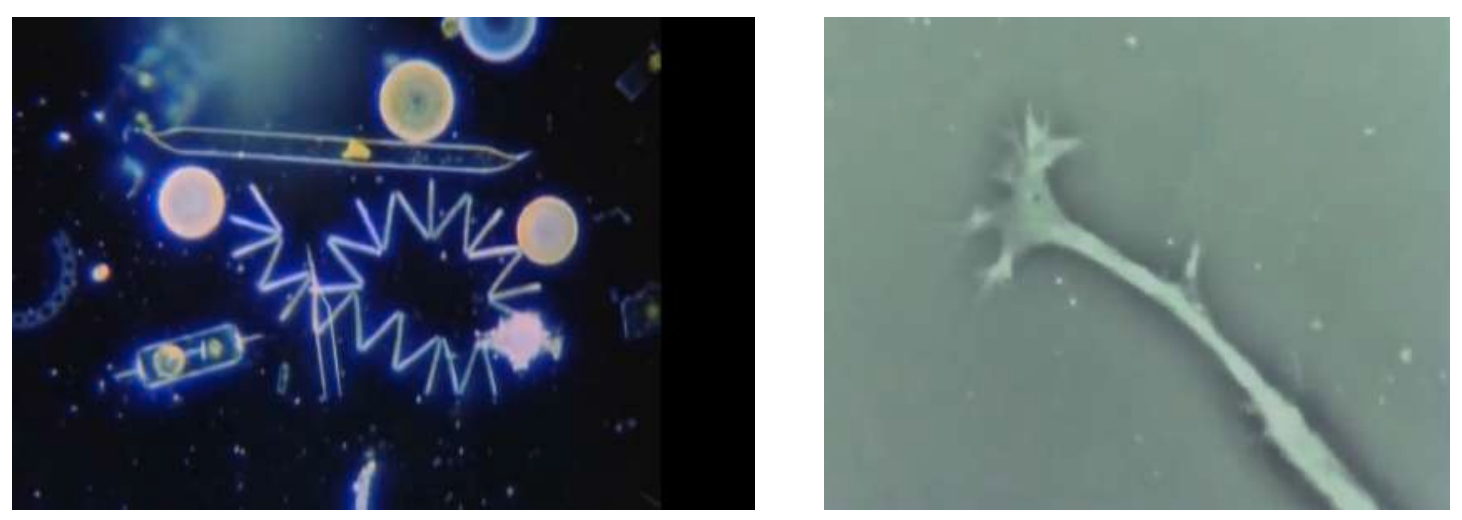

Figura 77 e 78: Origin of Oil (77) e World of Pulses (78). Fitoplâncons e um neurônio vivos confundem-se com pinturas abstratas. O espetáculo das imagens em movimento convoca uma camada mais profunda da sensibilidade cognitiva e penetra um universo simultaneamente fantasioso real. A realidade que escapa à percepção humana a olho nu e é revelada pela lente do cinema impregna-se do poder de sugestão. A beleza justapõe-se à tensão frente ao desconhecido e, assim, a possibilidade da existência metafísica invade o pensamento. $\mathrm{O}$ olhar poético habita $\mathrm{e}$ transcende a matéria. 
PARTE II 


\section{Capítulo III}

\section{De Revolutionibus e Nicholas Copernicus - poéticas da ordem e da desordem}

Após compreender que o cinema científico é uma manifestação híbrida, entramos no objeto de estudo desta pesquisa, os filmes De Revolutionibus, de Marcello Tassara, e Nicholas Copernicus, de Ray e Charles Eames, ambos a respeito da vida e da obra de Nicolau Copérnico. Por meio de uma análise comparativa entre eles, buscamos saber como se dá a contaminação do científico pelo poético e vice-versa, travando um diálogo em que ressaltamos pontos de contato e contrastes. Nesta altura da pesquisa, reconhecemos que Nicholas é menos científico, em um certo sentido, e mais históricobiográfico, do que De Revolutionibus. Ele não é científico no sentido estrito do termo, com demonstrações, explicações, imagens de experimentos, mas aproxima-se da ciência pela estética, pelos instrumentos e documentos materiais revelados em detalhe - uma alusão ao ato de observar de perto. Nicholas, realizado à mesma época e pelo mesmo motivo que De Revolutionibus, chega mesmo a operar plasticamente de modo semelhante, sendo portanto adequado para este estudo.

Buscando reconhecer aspectos comuns e os específicos, constatamos que o tratamento da dimensão poética é radicalmente distinto em cada um dos filmes.

O resgate dos filmes anteriores nas carreiras desses realizadores fornece valiosas pistas ou sugestões a respeito dos métodos de trabalho, bem como dos valores estéticos que cada um busca enfatizar.

\section{O primeiro filme da Escola de Comunicações e Artes é uma animação}

A história de De Revolutionibus remonta ao início da estruturação do curso de cinema na ECA. A maior parte dos professores não tinha pós-graduação e, em alguns casos, nenhuma passagem pela academia. Mas todos tinham experiência prática. Marcello Giovanni Tassara, físico que trabalhara em fábrica de refrigeradores, a convite de Roberto Santos fez parte da composição desse primeiro corpo docente, organizado por Rudá de Andrade e Paulo Emílio Sales Gomes. Tassara ministraria a disciplina de cinema de animação, já que exercia essa atividade como free-lancer em filmes de 
publicidade, e foi contratado em regime de notório saber.

O Roberto, que era um realizador inveterado, sujeito que não podia terminar um filme que já queria fazer outro, incentivou muito o Rudá - e o diretor da ECA na época, o Antônio Guimarães Ferri - a realizar um filme dentro do departamento. Para demonstrar que era possível, dentro da Universidade de São Paulo, fazer filmes. Como eu já conhecia o Roberto por outros caminhos, era um profissional com o qual trabalhei muitas vezes, ele acabou me convidando pra realizar o filme A João Guimarães Rosa, que foi o primeiro filme feito efetivamente pela ECA. Não posso dizer historicamente que tenha sido o primeiríssimo filme feito na USP, porque na Faculdade de Educação parece que tem algumas coisinhas que andaram sendo feitas. Nada de concreto, mais experiências sem consequência. Agora, o primeiro filme feito cabalmente, caracterizado como filme, foi o nosso. E foi a partir daí que eu foi convidado a participar da disciplina de Cinema de Animação. (TASSARA, 2017, ANEXO I).

A João Guimarães Rosa (1967) é um filme de doze minutos realizado integralmente na mesa de animação, com as fotografias de Maureen Bisilliat, em que se buscou a recriação do universo de Guimarães Rosa em obra audiovisual. A linguagem adotada aproxima-se de um filme-poema, não narrativo, em que a exploração exaustiva de trucagens sobre cada uma das fotografias estáticas direciona o olhar do espectador a determinados detalhes, enquanto o texto em off e a música em viola caipira sugerem uma atmosfera (Fig. 80). O trabalho de animação/montagem sobre a fotografia dos cavaleiros traz a sensação do galope, revelando, ao final da sequência, a fotografia estática matriz desse crono-caleidoscópio rítmico.
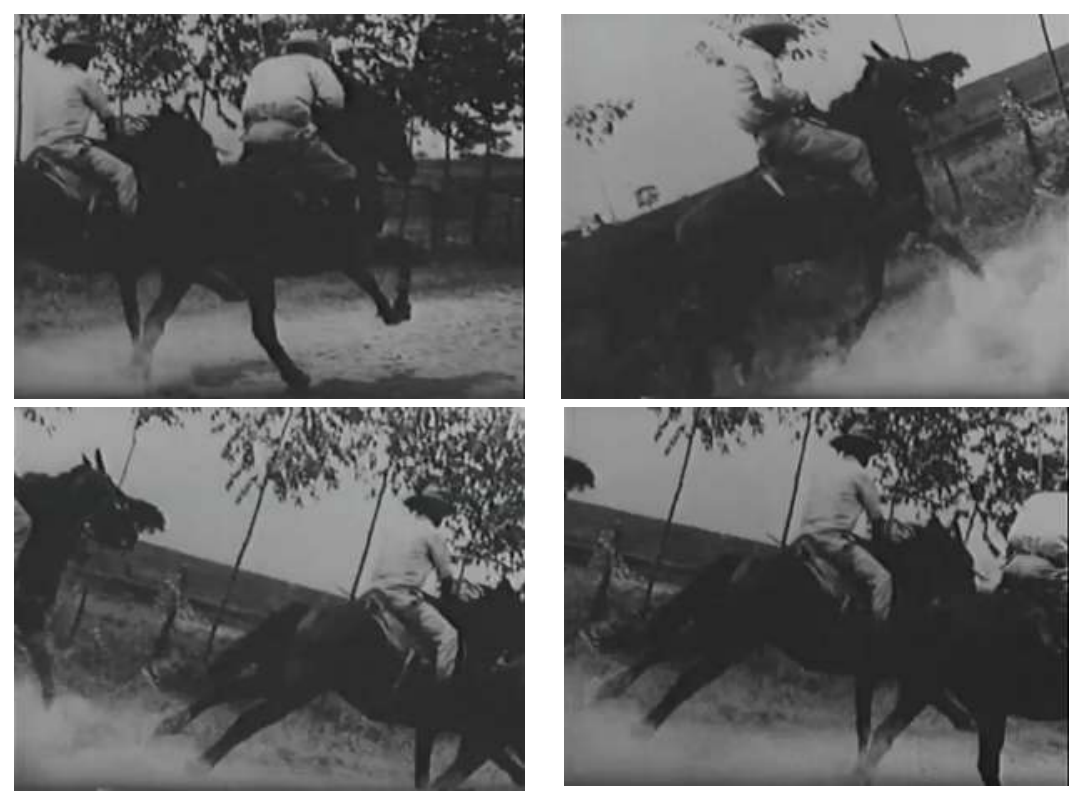

Figura 80: Sequência rítmica da galopada produzida com apenas uma fotografia do filme $A$ João Guimarães Rosa. Locução cita o trecho de Grande Sertão: Veredas: "Cavalo, cavalaria, cortejo que fazia suas voltas. [...] E os cavalos vagarosos; viajavam como dentro de um mar. 
Fora do cânone narrativo, Tassara experimentou trazer para a linguagem do cinema alguns recursos poéticos que Guimarães Rosa imprimiu em sua prosa como ritmo: rimas (visuais), repetições, cortes secos, enfim, produziram uma fusão entre o lírico e o narrativo na busca pela caracterização da geografia rosiana e do mundo interior das personagens. Assim como os neologismos de Rosa, o filme também "inventa" sua gramática com jogos visuais e sonoros, alternando momentos mais dinâmicos com calmaria, e extrai o máximo de uma mesma imagem até esgotá-la em tudo aquilo que ela tem a oferecer. Os silêncios reservados para a contemplação de uma única foto estática isolam o sentido da visão, partindo do detalhe para o conjunto e viceversa. Sobreposição de imagens diferentes, de imagens iguais, efeito estroboscópico e passeio do olhar sobre a imagem constituem alguns dos recursos de montagem que conferem uma dinâmica singular de manipulação do tempo no filme.

Sem o compromisso de emparelhar a locução e a trilha com a imagem, o trabalho de montagem escapa do literal explicativo e segue no registro da sugestão/proposição de um novo sentido derivado dessa conjunção som-imagem: podese pensar no terceiro sentido pensado por Eisenstein, em uma "estrutura polifônica feita de muitas linhas independentes" (EISENSTEIN, 1990, p. 56), nas quais o som e a imagem justapõem-se para a obtenção de um efeito final total, orgânico. Segundo ele, "ao combinar a música com a sequência, esta sensação geral é um fator decisivo porque está diretamente ligada à percepção da imagem da música assim como dos quadros" (EISENSTEIN, 1990, p. 56).

$\mathrm{O}$ intenso trabalho sobre as interações entre som e imagem visto em $A$ João Guimarães Rosa decorre da reflexão em torno da possibilidade de criação de sentidos a partir da colagem de unidades significativas para a composição de um movimento expressivo. De Revolutionibus segue esta tendência e vai além, ao adicionar saltos espaço-temporais como sugestivas interrogações ao espectador.

\section{A colaboração na USP entre o IF e a ECA}

Ao final da década de 1960, entre 1968 e 1970, o físico mexicano naturalizado norte-americano Albert Baez ${ }^{23}$ esteve no Brasil por um mês a convite do prof. Ernst Hamburger, do Instituto de Física da USP (IF), para ministrar um seminário a respeito

\footnotetext{
${ }^{23}$ Albert Baez (1912-2007) contribuiu para o desenvolvimento da ótica dos primeiros microscópios com raio-x e, mais tarde, com telescópios em raio-x. Também foi pai da cantora Joan Baez.
} 
de filmes de popularização científica. Baez, que também trabalhara com o Physical Science Study Cometee (PSSC), trazia vasta experiência em consultoria para os filmes didáticos da Encyclopaedia Britannica, destacando-se a série Learning about Light, Learning about Heat, Learning about Nuclear Energy, entre quase uma centena de títulos. Sua presença incentivou que se produzissem filmes de ciências para sala de aula.

Uma das consequências dessa visita foi a criação do Grupo de Produção de Filmes Didáticos (com apoio da Fapesp), uma colaboração entre o IF e a Escola de Comunicações e Artes (ECA), para a produção de uma série de filmes curtos, de quatro minutos cada. Realizados entre 1971 e 1974, essa produção fez parte da pesquisa de mestrado desenvolvida pelo prof. Mikyia Muramatsu, ${ }^{24}$ orientando do prof. Hamburger, cujo título era Avaliação de filmes didáticos de física. Na parceria entre o IF e a ECA, a equipe da Física traçava o objetivo e a metodologia da pesquisa, definia o conteúdo, e executava os experimentos. A equipe da ECA, sob direção de Marcello Tassara, cuidava da filmagem e da finalização dos filmes. Foi de extrema importância que houvesse alguém, no caso, o prof. Tassara, que tivesse conhecimento suficiente nas duas áreas, tal como o papel de um tradutor.

\footnotetext{
A presença do diretor de cinema foi importante na elaboração do argumento para se discutir a melhor utilização da linguagem cinematográfica, a ordem mais conveniente dos planos e a aplicação dos recursos de trucagem e animação. (MURAMATSU, 1976, p. 14)

É imprescindível que as experiências propostas no roteiro estejam prontas e exaustivamente treinadas antes do início das filmagens. (TASSARA, 2016, ANEXO I)
}

Foram realizados dezoito filme-loops em película sobre os tópicos centro de massa e colisões. Armazenados em cartuchos, o estudante podia assisti-los quantas vezes desejasse, utilizando um visualizador individual. Para a etapa de avaliação da eficácia dos filmes no aprendizado, foram sorteados 1.200 estudantes do primeiro semestre da disciplina de Física, dos cursos de graduação na Física, na Química, na Escola Politécnica da USP (POLI), na Matemática e na Geologia, os quais foram divididos em três grupos de quarenta estudantes, cada qual submetido a uma atividade. Como conclusão da tese, observou-se uma diferença considerável na nota obtida pelos estudantes que assistiram aos filmes, atestando melhor compreensão do tema estudado.

Passados 43 anos, tentamos recuperar este material, do qual não se tem registro

\footnotetext{
${ }^{24}$ No Anexo V, encontra-se um artigo com o objetivo, o método e o resultado da pesquisa.
} 
seja no catálogo da ECA, seja no IF. O prof. Mikyia Muramatsu, atualmente livredocente, manteve algumas das latas de negativos do que restou desses filmes em um pacote pardo, em sua sala no departamento de Física. Infelizmente, entre sobras de copião e de negativos, salvaram-se apenas as cópias em 35 milímetros de quatro desses filmes: Energia 1 - energiômetro: projeto, Energia 2 - energiômetro: calibração, Centro de massa e impulsão. A digitalização destes filmes, feita na Cinemateca Brasileira, representou o resgate de uma empreitada extremamente bem-sucedida no campo da educação. Sua análise contribuiu de forma definitiva para a apreciação dos demais filmes de Tassara, servindo de ponto de partida para a análise de De Revolutionibus.

Sem nos aprofundar na análise desses filmes, apontamos a seguir algumas marcas de cientificidade e algumas estratégias adotadas para manter o interesse do espectador e propiciar a apreensão de conceitos. Veremos que essas marcas são o denominador comum de muitos filmes científicos da carreira de Tassara.

Analisar esteticamente filmes incumbidos de expor conceitos teóricos parece tarefa superficial, já que eles têm pouco a dizer, além do que está dado em sua primeira leitura, no cumprimento eficiente da função denotativa. No entanto, a própria escolha pelo suporte filme sugere a inclusão da abordagem estética nas práticas didáticas. Como aponta Jacques Aumont (2009, p. 17) a "concepção do belo, [...] do gosto e do prazer do espectador" constituem o eixo central da fruição. Cada imagem em um filme científico, além de cumprir sua função informativa, traz em si aspectos provocativos e instigantes ao intelecto. Os elementos da composição fílmica entram em ação para oferecer ao espectador um conteúdo traduzido nas melhores imagens, evitando a simples transposição de uma aula expositiva.

Nos anos 1970, a discussão em torno dos recursos audiovisuais no ensino dividia opiniões quanto a sua eficácia. O rigor formal dos filmes do Physical Science Studies Cometee (PSSC) nem sempre atraía a simpatia do público. Como já foi visto no Capítulo I.III, o modo de enunciação frio e distante, com o professor vestindo terno e gravata, posicionado frontalmente, em um laboratório bem equipado, evidencia a posição de superioridade daquele que detém o saber. Este modelo do PSSC apresenta momentos de beleza no testemunho de leis da física, o que é conveniente para o ensino objetivo, principalmente em larga escala. Mas, de modo geral, apresenta um universo enquadrado e obediente às regras que a ciência tenta categorizar. Não há uma contextualização cultural de como a teoria demonstrada chegou a ser elaborada, 
tampouco desdobramentos do conceito demonstrado para algum aspecto da vida além do laboratório. O conhecimento já vem pronto. Os filmes do PSSC correspondem a um modelo que passou a ser questionado em vista das metodologias ativas de ensino que empregam o formato cinema-vídeo de uma forma mais participativa do espectadoraluno.

Voltando aos filmes da série Centro de massa, o primeiro deles faz a introdução ao tema, é uma espécie de vinheta de abertura, operando de modo semelhante a $A$ João Guimarães Rosa na exploração das imagens estáticas: a câmera passeia por elas, realiza zoom-in e zoom-out e fusões. Na montagem, as fusões, alternadas com cortes secos trabalham as relações entre os contrastes e as semelhanças, a natureza e a obra humana, o eterno e o efêmero. O espectador tem tempo de percorrer a foto com o olhar e de imaginar a relação que elas têm entre si e com o título do filme.

Tomemos como exemplo a imagem estática do Sol poente que se funde com o topo de um foguete acionando ignição. A câmera faz o travelling-down até o solo, mostrando chama e fumaça em uma paisagem lacustre. Corta para o movimento travelling-up revelando um automóvel moderno. Corte seco para as pernas do jogador de futebol em plena disputa pela bola. O filme segue com essa lógica de nos apresentar detalhes das imagens que, a partir da montagem, convidam a refletir sobre a realidade circundante, cotidiana, e sobre nossa imersão no cosmo (Fig. 81). Nesste filme, ainda não se expõe um conceito específico, mas evidencia-se que estamos falando de energia em suas diferentes manifestações: luz, calor, movimento, vida.
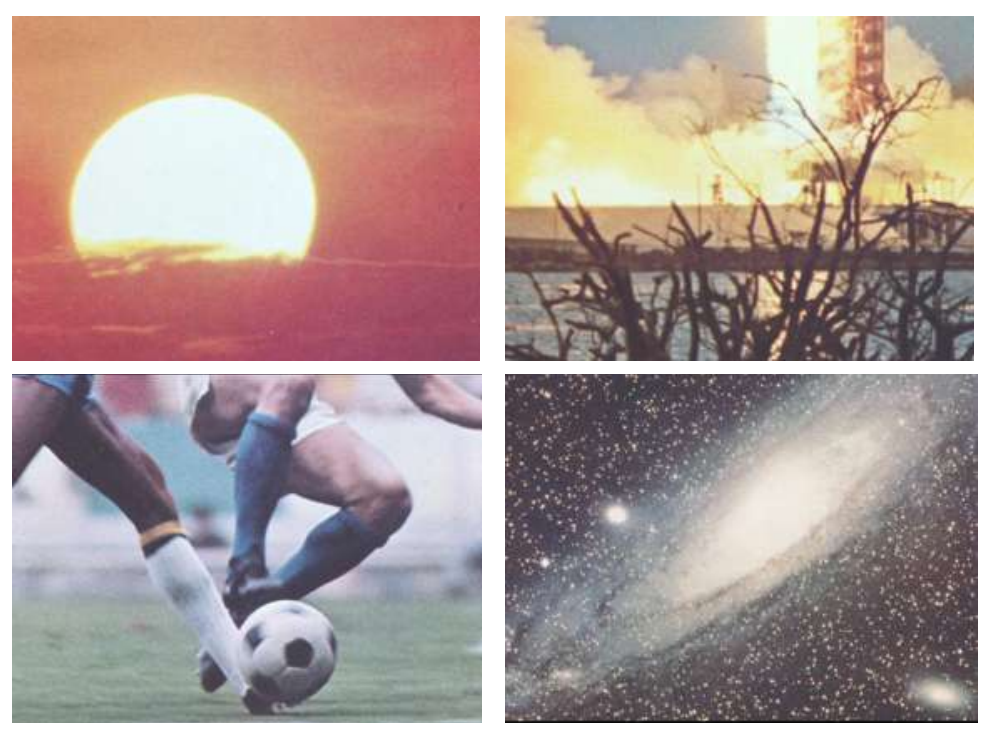

Figura 81: Planos da vinheta da série Centro de massa (1972) trazem ao espectador a atmosfera temática sobre a qual os demais filmes irão trabalhar. 
Nos filmes Energia 1, Energia 2 e Impulsão, observa-se inicialmente o apelo visual predominantemente limpo, uma plástica da clareza temperada com um tom de "aventura" (BARTHES, 1980, p. 36), em que a composição dos planos obedece a uma disposição equilibrada dos elementos da cena. Mas há um elemento surpresa nessa sobriedade, dado principalmente pela montagem. A figura do cientista de guarda-pó branco é evocada pela metonímia: apenas as mãos entram em campo, manipulando os equipamentos no labotarório.

Em todos os três filmes, há um plano inicial de preparação da experiência que veremos a seguir: a apresentação do "palco", a mesa da cena, e dos "personagens", os objetos utilizados no experimento. $\mathrm{O}$ objeto em questão nessa experiência/cena é o chamado puck, e consiste em um cilindro de metal em cujo interior há um espaço preenchido de nitrogênio líquido, o qual, ao evaporar na temperatura ambiente, vasa pela parte inferior do objeto, formando um "colchão" de ar. Isso permite a minimização do atrito do objeto com a mesa.

Nas figuras 82 a 93, observamos com os intertítulos são introduzidos.
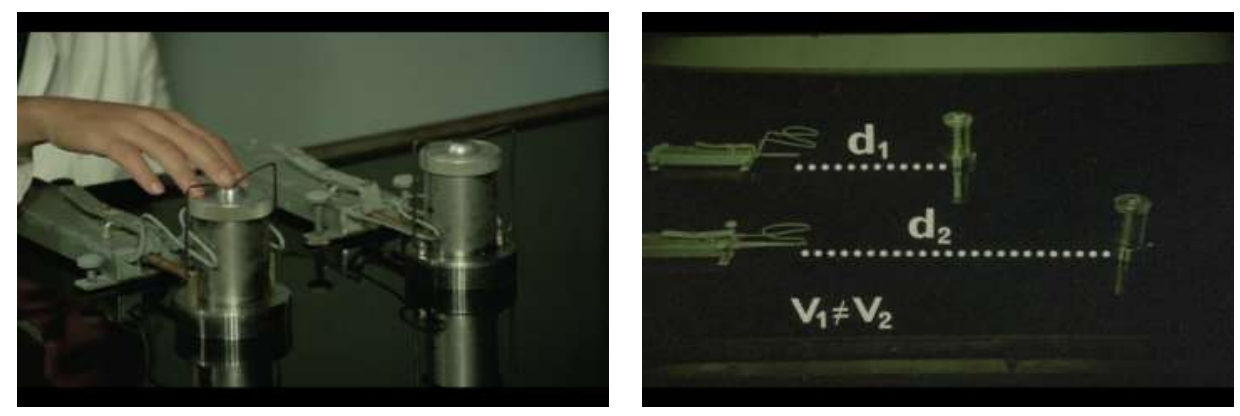

Figuras 82 e 83: Sobre uma mesa de atrito mínimo ideal, dois lançadores à mola vão empurrar os pucks, objetos com determinado peso contendo hidrogênio líquido, o qual, ao evaporar pela parte inferior do objeto, reduz ainda mais coeficiente do atrito.
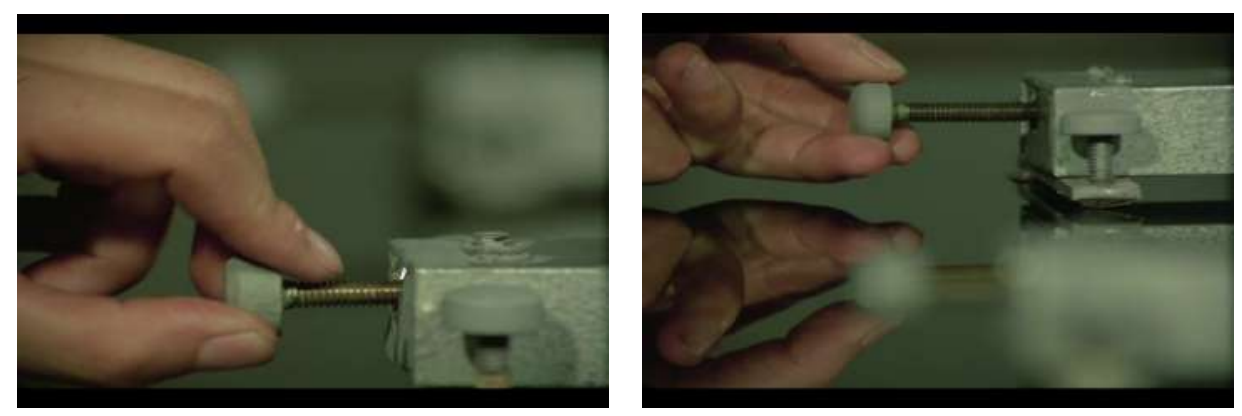

Figuras 84 e 85: Calibragem do lançador de pucks. Plano lateral sobre mesa polida. Correção do foco que evidencia a mesa lisa, espelhada. 

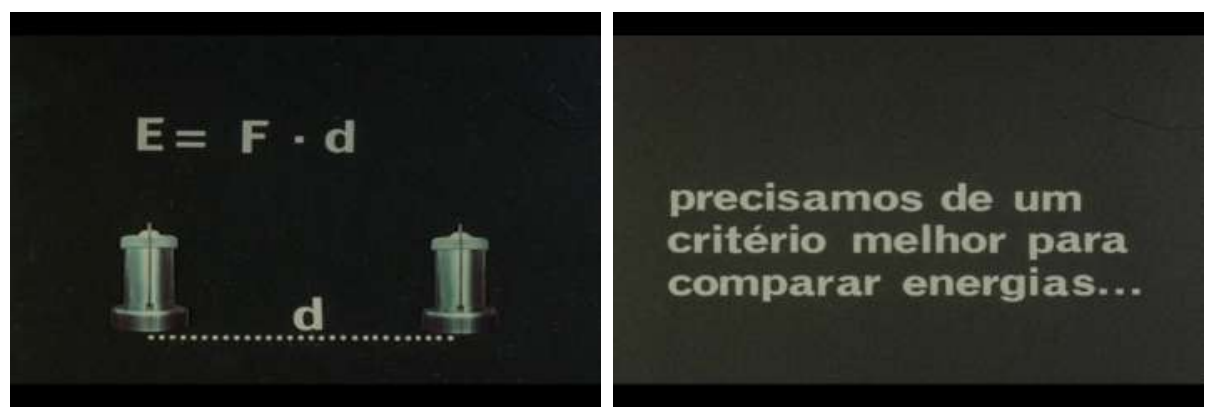

Figuras 86 e 87: Intertítulos enunciam: Energia = Força x Distância.
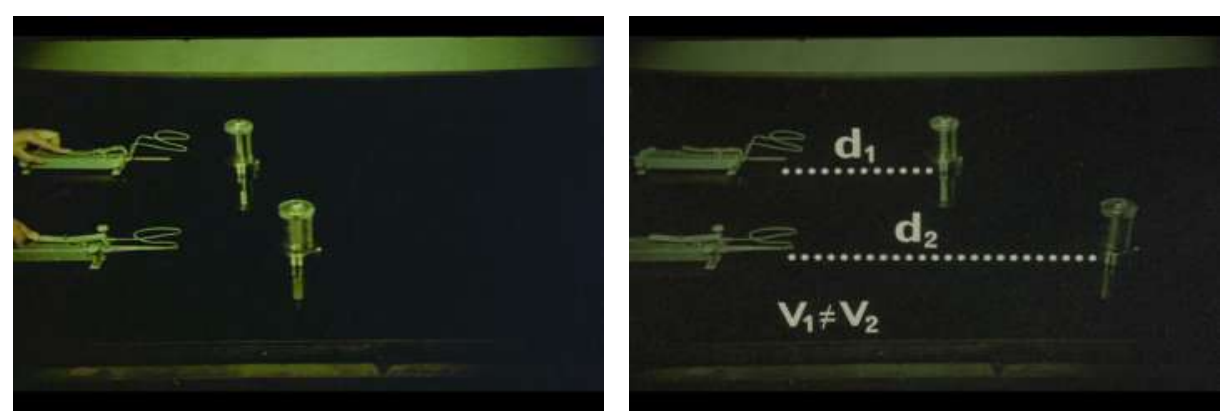

Figuras 88 e 89: Instantes após o lançamento dos pucks, congela-se a cena e inserem-se os dados.


Figura 90 a 93: Da esquerda para a direita, de cima para baixo, o puck desliza até a mão do pesquisador até o zoom-in no objeto. Toda a sequência, da Figura 82 à 93 , são cenas de Energiômetro 1 (1972).

Uso de desfoque em profundidade de campo, planos próximos e zoom-in são alguns dos recursos que evidenciam o domínio da linguagem de cinema, de um método 
de "narrar" e "dialogar" com o espectador, de propor questões para pensar. O plano rente à mesa, por exemplo, é uma opção de tomada que reforça o aspecto espelhado e liso da superfície, pelo ângulo de reflexão da luz incidente, o que reitera a situação de atrito mínimo. Ou seja: não se trata do registro simples de um experimento, mas da decupagem mais adequada para o entendimento do conceito em linguagem não verbal. Apesar da sobriedade, da seriedade dos filmes, a sutileza no uso dos recursos da linguagem cinematográfica confere-lhes uma qualidade estética que propicia ao mesmo tempo a fruição e a compreensão.

1973 - Os 500 anos de Nicolau Copérnico: De Revolutionibus e Nicholas Copernicus

Arthur Koestler, jornalista e escritor húngaro, é o autor de $O$ homem e o universo (1959), texto referência para a criação do roteiro do filme De Revolutionibus. Nessa obra, Koestler estuda as transformações da cosmovisão humana através dos tempos, retratando a evolução histórica em contraponto com os conflitos do homem que habita o cientista, e o complexo (des)equilíbrio entre ciência e religião. Inicialmente intitulado com o sugestivo nome Os sonâmbulos, o homem e o universo, o livro ganhou o novo nome na edição de 1989. Os protagonistas Nicolau Copérnico, Galileu Galilei e Johannes Kepler viveram em uma época em que a ciência e o misticismo eram uma coisa só, e representaram o início da dissociação dos caminhos da ciência e da religião. Além de apresentar um amplo repertório das mais variadas teorias criadas pela humanidade para explicar a origem e o funcionamento do cosmos, um dos aspectos que chama a atenção é a elaborada escrita de Koestler. Seu texto traz imagens, metáforas e muitas vezes apela para um tom poético na exposição de um conceito, algo que ele próprio reconheceu nos textos dos cientistas que estudou.

Em 1973, aos 500 anos do nascimento de Nicolau Copérnico, vários países promoveram eventos em homenagem ao cientista. Fortes e muitos são os motivos, ainda que o tamanho de sua contribuição não seja unanimidade no meio científico. O próprio Koestler (1989 [1938], p. 135) é implacável na avaliação do cientista e critica a importância atribuída a sua teoria:

O vulto de Copérnico, visto de longe, é o de um intrépido herói revolucionário do pensamento. Ao nos aproximarmos, transforma-se aos poucos no de um pedante inchado, sem o faro, sem a intuição sonâmbula do verdadeiro gênio, e que, tendo apanhado uma boa ideia, a desenvolveu num mau sistema, lidando pacientemente, amontoando mais epiciclos no mais 
sombrio e ilegível dos livros que fizeram história.

Koestler (1989 [1938], p. 99) argumenta que o que levou o astrônomo a demorar tantos anos para imprimir seu livro foi mais a vergonha do ridículo entre seus contemporâneos do que a perseguição religiosa.

\footnotetext{
O que chamamos de revolução copernicana não foi efetuada pelo cônego Copérnico. O seu livro não se destinava a provocar uma revolução. Sabia ele que muito do que lá estava exposto não era são, que contrariava a evidência e que a hipótese básica era improvável. Acreditava nele apenas pela metade, à maneira de espírito dividido da Idade Média. Ademais, não era dotado das qualidades essenciais do profeta: certeza de missão, originalidade de visão, coragem de convicção.
}

Por outro lado, o astrofísico e historiador Owen Gingerich, discordando desta posição, passou trinta anos viajando pelo mundo em busca das cópias sobreviventes da obra de Copérnico com o objetivo de saber quem afinal a leu. Nas quase seiscentas cópias que catalogou das duas primeiras edições, Gingerich identificou os exemplares que pertenceram a Kepler, Galileu e Christopher Clavius, entre outros, como livro didático. Esses livros também passavam de mão em mão e continham várias anotações nas margens. Gingerich conseguiu com isso imaginar o caminho do pensamento que levou diversos cientistas e matemáticos a desenvolver suas próprias teorias a partir dos cálculos de Copérnico. Para ele, Galileu, Kepler e Copérnico foram cientistas criativos que ousaram pensar "fora da caixa" e deixar que o seu senso de estética se sobrepusesse ao senso comum (in MACFARLANE, 2008). Outro estudioso, Robert S. Westman (apud HENRY, 1998, p. 23), conclui que Copérnico foi um "inovador radical na astronomia e na formação de um novo papel para o astrônomo - um fisósofo natural”. Admitir o "movimento da Terra por que a matemática o exige", foi revolucionário, já que confere ao planeta seu verdadeiro status no cosmos a partir da abordagem não teocêntrica (HENRY, 1998).

Não foi coisa simples o cônego libertar-se do ideário teocentrista tecido ao longo de dez séculos e olhar para o céu de uma forma diferente da de seus antepassados. Defender uma nova cosmologia soaria uma aberração. Quando Copérnico colocou o Sol no centro, onde antes habitava a Terra, imediatamente percebeu que os outros planetas "organizaram-se" em órbitas ao redor do Sol: "Foi uma bela ideia de unificação. De repente você tem o mesmo padrão de movimento para cada planeta, quando antes cada um tinha um mecanismo diferente. Acho que foi a força dessa estética que convenceu 
Copérnico" (GINGERICH in MACFARLANE, 2008). A ideia do belo como algo que dá sentido, que organiza a visão, e que acorda a compreensão frente ao caos da natureza é presente em numerosos textos científicos, sem conotação moral ou juízo de valor, mas apontando para algo que se torna inteligível, dá segurança e previsibilidade. Sem prever ou desejar, Copérnico lançou as bases da ciência moderna, sobre as quais, séculos mais tarde, Kepler, Galileo e Newton formularam toda base da física clássica que promoveu a evolução do conhecimento em todas as direções.

Além da importância histórico-científica, outra questão motivava a série de eventos relacionados a Copérnico. À época da Guerra Fria, historiadores e eruditos poloneses promoveram comemorações e acreditavam que o ano de 1973 seria uma oportunidade única para estabelecer/reforçar laços acadêmicos com o Ocidente. Owen Gingerich, entre outros astrofísicos e estudiosos, foi convidado a participar do comitê que organizou as celebrações tanto na Europa como nos Estados Unidos, como mostra esta matéria do New York Times de 28 de dezembro de 1972:

\begin{abstract}
Diversas conferências e exibições acontecerão em 1973, entre elas um grande simpósio internacional patrocinado pela Nações Unidas Educacional, e pela Organização Cultural e Científica de Paris, em 19 de fevereiro, aniversário de Copérnico. De 20 a 25 de abril, a Academia Nacional de Ciências vai realizar uma grande conferência sobre "A natureza das descobertas científicas" no Instituto Smithsonian. Tudo vai culminar na Polônia, onde o orgulho local transformou a data em um evento de abrangência nacional. Haverá um encontro de acadêmicos em setembro em Torun, onde Copérnico nasceu. Os nova-iorquinos poderão ter uma amostra disso em uma exposição elaborada pelo designer Charles Eames. (REINHOLD, 1972, s.p.)
\end{abstract}

A IBM contratou o escritório de arquitetura e design de Ray e Charles Eames (consagrados pelas modernas poltronas) para realizar uma grande exposição itinerante sobre os 500 anos de Nicolau Copérnico. Bernard Cohen, então consultor de história da ciência na IBM, convidou Owen Gingerich para compor a equipe que montaria a exposição. Parte desse trabalho foi a realização de um filme, Nicholas Copernicus, o qual, juntamente com outros artefatos e imagens, tornavam a exposição uma experiência multimídia, algo bastante inovador para a época. Com a aproximação do ano de 1973, Gingerich $^{25}$ já previa que seria chamado para algum evento semelhante, posto se tratar do mais conhecido especialista em Copérnico. Em sua obsessiva pesquisa, tinha o objetivo de encontrar algo que ainda não fora dito.

\footnotetext{
${ }^{25}$ Gingerich conhecia bem a obra de Arthur Koestler sobre Copérnico e discordava deste, no sentido de que Koestler declarava De Revolutionibus como um livro pouquíssimo lido e menos importante na astronomia.
} 
No Brasil, a motivação para retratar Copérnico soa mais prosaica, menos ligada a um movimento mundial do que a uma conjuntura local. Remontando o início da ECA, trabalhavam para a consolidação do cinema na universidade Paulo Emílio Salles Gomes, Rudá de Andrade e Roberto Santos, entre outros. Rudá teve a iniciativa de realizar De Revolutionibus, talvez por influência de sua esposa Halina, polonesa como Copérnico, e conseguiu do Instituto Nacional do Cinema (INC) uma verba para produzilo. Entretanto, o filme não "saía da gaveta", por uma dificuldade de compreensão do tema por parte dos envolvidos. Por causa disso, segundo relembra o diretor, a produção ficou cerca de seis meses parada. Algumas imagens foram captadas e produzidas, sem que se tivesse um fio condutor de uma possível narrativa. $O$ filme passou a ser visto pelo corpo docente da ECA como um compromisso de dificílima execução, "uma montanha intransponível". Devido à demora na entrega, o INC ameaçou denunciar o contrato com a ECA.

[...] de vez em quando a gente tem esses lances; eu, como tinha uma certa paixão, tenho uma paixão por esse tema, principalmente astronomia, astrofísica etc. Então eu falei: "Assumo a direção do filme. Faço o roteiro e termino a direção do filme". A partir daí, o INC já estava em cima, já estava disposto a denunciar o convênio; então, o que eu fiz? Arumei uma verba lá na ECA, fui até o Rio de Janeiro, onde era a sede no INC e me comprometi pessoalmente a terminar o filme. (TASSARA, 2017, ANEXO I)

Demorou muito tempo pra fazer o filme. Foi feito em etapas, então, no meio de todos os trabalhos, porque a gente tinha os nossos pessoais; até o filme do Roberto Santos estava sendo feito junto, em paralelo... junto com tudo isso, de vez em quando, tinha um Copérnico que o Tassara pedia pra fazer. Porque tinha dinheiro do INC nesse filme. Então, era uma coisa que tinha prazo pra cumprir, tinha uma missão pra cumprir, mas toda preocupação não chegava até os fotógrafos. (DURST, 2017, ANEXO III)

De volta a São Paulo, Tassara reuniu equipe para fazer a pesquisa e redigir o roteiro, filmar, montar e finalizar em um prazo de cerca de dois meses. Os pesquisadores-roteiristas eram ele mesmo, sua esposa, Eda Tassara, Ismail Xavier e Rudá de Andrade, os fotógrafos graduandos, Ella Durst e Chico Botelho, com a produção de Guilherme Lisboa e Manfredo Bahia e a montagem de Maria Dora Mourão. $^{26}$

Uma coincidência que favoreceu a produção foi que, na mesma época, Roberto Santos finalizava o filme As três mortes de Solano, cujo protagonista, Stenio Garcia, circulava pela ECA para fazer a dublagem. Tassara relata que encontrou-o pelos

\footnotetext{
${ }^{26}$ Segundo Ella Durst, todo mundo na ECA participou deste filme, inclusive o montador Eduardo Leone.
} 
corredores e fez o convite para que participasse do De Revolutionibus, como a voz de Nicolau Copérnico. Aceito o convite, Garcia emprestou seu timbre ao astrônomo, e o filme passou a ser veiculado no Planetário de São Paulo, na Sociedade Brasileira para o Progresso da Ciência (SBPC), em escolas públicas e também fora do Brasil, na Polônia, inclusive.

\section{Decisões narrativas}

De Revolutionibus consiste em um filme de curta-metragem (dezoito minutos), composto de texto (narração em voz off), músicas e imagens captadas ao vivo alternadas com fotos animadas em equipamento de trucagem, com os recursos de dupla exposição, zoom, fusão, fades. O filme retrata o contexto em que Nicolau Copérnico desenvolveu a teoria heliocêntrica, em que ela consiste e seu desdobramento para a consolidação da física clássica. Também discute onde está a verdade no embate entre as visões de mundo da religião e da ciência e finaliza apontando que a investigação científica vai muito além do que os fatos observáveis nos mostram.

O filme foi concebido a partir de pesquisas de Eda Tassara, Ismail Xavier e Marília Franco em torno da obra De Revolutionibus Orbium Coelestium [Sobre as revoluções das esferas celestiais], livro seminal da teoria heliocêntrica. Chama-nos a atenção o fato de que vários excertos das locuções do filme, sobretudo as falas de Copérnico, tenham sido extraídos da obra de Koestler, seu mais célebre crítico, o homem que diminui o vulto de Copérnico, como já mencionamos. A equipe contou também com um número enorme de imagens coletadas em várias bibliotecas e em acervos particulares.

Comenta Ella Durst, uma das fotógrafas do filme, que a produção é "uma colcha de retalhos, um tratado de semiótica" (DURST, 2017, ANEXO III). Aqui vale ressaltar a divergência entre os relatos de Durst e de Tassara, posto que, na memória de Durst, Tassara realizara o filme como exigência acadêmica em substituição a uma tese de doutorado, para poder continuar na docência, sob a orientação de Eduardo Peñuela, e atendendo ao interesse deste pelo campo da semiótica. Tassara nega que esta tenha sido a motivação para o filme, relata ter concebido o filme a partir de seu interesse pessoal pelo tema e da pesquisa realizada pela equipe. O período de 46 anos que separa as entrevistas desta pequisa da época em que o filme foi feito parece ter diluído e embaralhado as memórias da equipe, o que atestam as contradições nos discursos. 
Outro membro da equipe, a montadora Maria Dora Mourão, não guardava lembranças sobre o filme quando o reviu e nos concedeu entrevista. Depois dos primeiros minutos de projeção, comentou: "Mas o que foi que surpreendeu você? Até agora, é um filme superconvencional, não tem nada de diferente" (MOURÃO, 2017, ANEXO II). Dito isto, ela continuou a assistir o material, até que uma inflexão radical na estrutura do filme revelou-lhe uma exploração de linguagem digna de um olhar mais atento.

De Revolutionibus é uma obra que merece ser atravessada por um olhar múltiplo. O método iconológico exposto por Erwin Panofsky em Significado nas artes visuais contribuiu para pensar o filme e o que ele traz de único em sua proposta construída fora dos cânones clássicos. Em seu percurso interpretativo, Panofsky (1976) considera as componentes intelectuais, formais e as motivações históricas, e organiza o trabalho analítico em três fases: descrição, análise cultural, interpretação. A “capacidade de deslocar da arte antiga para a moderna, de trazer insights provocativos das áreas da filosofia, da ótica e da psicologia [...] fazem de Panofsky um ponto de partida para o estudo do que chamamos "cultura visual"” (MITCHELL, 1994, p. 16). ${ }^{27}$ O método de Panofsky pareceu dar conta das articulações de imagens e de montagem, estabelecendo sempre a ponte entre a história, o pensamento, a arte e a estética. De um modo geral, leva a questionar o que faz uma imagem representar algo (AVANCINI, 2011).

Não é nossa proposta esmiuçar toda teoria iconológica, mas aproveitar de sua contribuição na leitura do filme de Tassara. Segundo o método iconológico, há uma hierarquia no modo de contemplar a obra que pressupõe, em primeiro lugar, a observação/descrição dos elementos formais da imagem. Trata-se do nível primário, o mais básico da compreensão. Quando falamos em imagem, falamos do conteúdo formal plano a plano, e também do valor da montagem, da criação de sentido na relação entre os planos e com a trilha sonora. Neste nível, basta-nos a visão para reconhecer estilos e motivos.

O segundo patamar de interpretação em profundidade, o nível secundário, refere-se ao significado da imagem determinado por uma convenção, e à intenção

\footnotetext{
${ }^{27}$ Mitchell é um estudioso das ciências humanas que identificou o final do século XIX como o período da pictorial turn, ou seja, uma virada, uma nova etapa em que as imagens ganham ênfase.
} 
consciente do autor, ainda que algumas qualidades expressivas da obra não sejam intencionais. Os motivos artísticos são apreendidos associados a um conceito, o que demanda mais do que apenas a experiência prática, mas o conhecimento de temas específicos prévios. Finalmente, o terceiro nível de interpretação corresponde ao significado profundo da obra, à compreensão do significado intrínseco ao seu conteúdo, que revela a atitude básica do autor em seu contexto cultural e dentro da tradição de um estilo determinado por uma convenção cultural.

O filme inicia com uma longa sucessão de imagens (1'12'), entre reproduções de pinturas, litografias e fotografias, que contextualizam o assunto do filme no espaçotempo. Reconhece-se na iconografia medieval a indicação da época, e a localização textual contida nas três primeiras imagens fornece o local preciso: a cidade de Torun, nas proximidades da Cracóvia e de Frauenburg, na atual Polônia. Então, como quem aterrissa dentro dos muros do feudo, no castelo de Heilsberg, somos informados da disposição das mesas do refeitório conforme o estrato social pelo narrador em voz over:

\begin{abstract}
Um decreto do castelo de Heilsberg do século XV descreve pormenorizadamente o pessoal da corte do bispo, a sua ordem de precedência e a etiqueta de mesa. Ao som do sino do jantar, todos os residentes e hóspedes devem esperar nas portas dos aposentos até que o bispo entre no pátio pavimentado, anunciado pelo ladrar dos cães soltos naquele momento. Quando o bispo, com mitra, cajado e luvas de púrpura, aparece no salão, forma-se um cortejo que o segue à sala dos cavaleiros. [...] Há um total de nove mesas: a segunda fica reservada aos membros superiores, a terceira, aos inferiores, a quarta aos principais servos, a quinta aos pobres, as sexta, sétima e oitava aos servos de categoria inferior e aos servos dos servos, a nona aos prestidigitadores, bufões e charlatães que distraem a comitiva. Não sabemos a que mesa estava destinado Nicolau; devia ser, presumivelmente a segunda. (KOESTLER, 1989 [1938], p. 90)
\end{abstract}

Para a criação dessa atmosfera austera e cerimoniosa, a sequência das fotos leva o olhar do espectador às abóbadas e aos arcos góticos em movimentos de câmera verticais, na direção do céu, ao som do badalo dos sinos e do ladrar dos cães. Aos poucos, o vozerio dos comensais adensa a trilha do som, acompanhando as imagens que, de modo gradual, apresentam mais e mais figuras humanas povoando a cena.

Às fotografias estáticas dos corredores em arcos, sobrepõe-se a filmagem de uma sombra que se desloca tal como a de alguém que caminha sobre um piso de pedras. Esta filmagem, tomada na USP, provê a cena de mistério, posto que se vê a sombra, mas não quem por ali passa, numa solução criativa que contribui para dar movimento à cena.

Esta contextualização inicial é sucedida pelos créditos e, em seguida, por uma 
explicação textual (voz over) de como Giordano Bruno, reforçou sua teoria a partir do pensamento de Copérnico, sendo condenado à morte na fogueira. Anos mais tarde, foi a vez de Galileu Galilei dialogar com o texto de Copérnico, sendo também ameaçado de morte na fogueira, já que De Revolutionubus Orbium Coelestium fora colocado no Index da Inquisição.

Além das reproduções fotográficas trazendo as imagens de Giordano Bruno e Galilei, algumas tomadas ao vivo de uma fogueira e de locações campestres são a solução para representar o Campo das Flores onde Giordano Bruno sofreu a execução. É uma passagem em que a montagem alternada Giordano/fogueira/Giordano/fogueira remete a um jogo de montagem eisensteiniana de justaposição, solução criada para conferir ritmo e sentido à montagem. Mesmo assim, em uma análise crítica dessa composição, incumbida de trazer o máximo de emoção e de vigor estimulante (EISENSTEIN, 1990, p. 14), a composição soa anacrônica, seja pela lentidão de alguns planos, seja pela repetição do recurso: "para os dias de hoje, ele é lento" (MOURÃO, 2017, ANEXO II).

Ismail Xavier (ANEXO IV), assistindo à projeção, comentou que o filme

[...] teve o aspecto de situar a época para além da questão da ciência. Depois tem uma parte visual, que tem seu aspecto poético na questão da natureza, na tentativa de fazer algumas imagens que pudessem trazer uma experiência visual principalmente para o espectador, que criasse uma série de estímulos que fossem sugestivos, pra pensar, pra fazer conexões...

Outra solução da montagem/trucagem é o curioso zoom-in na boca de Nicolau Copérnico no momento em que entra a voz de Stenio Garcia à melodia do Lamento di Tristano, ${ }^{28}$ indicando quem é o dono da voz que nos explica a origem da nova cosmovisão (Fig. 94).
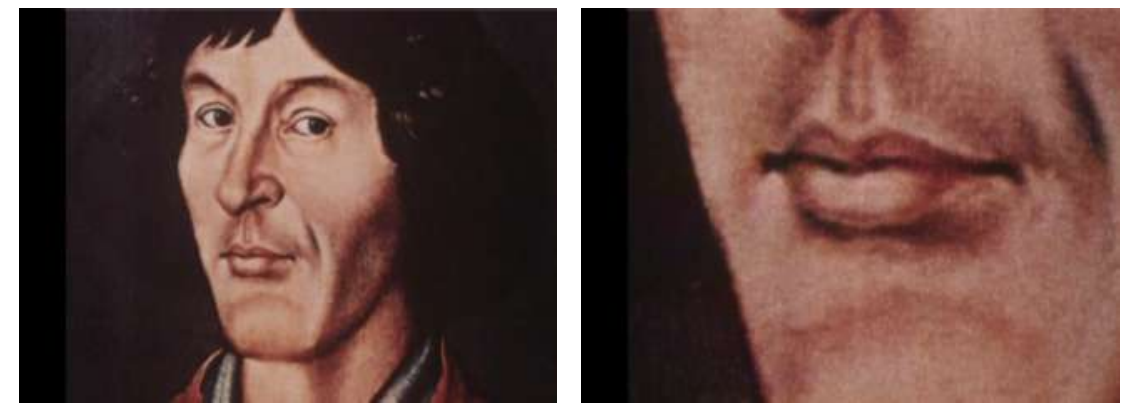

Figura 94: Zoom-in para a boca de Copérnico em sincronia com sua fala.

${ }^{28}$ Il Lamento De Tristano, Anonymous, século. XIV. 
Até aqui, o que se vê são variações da técnica de animação em table-top, ou seja, fotografias animadas com mais ou menos recursos, alternadas com tomadas em filmagem captadas a 24 quadros por segundo, em consonância com a informação do narrador em voz over, objetivando proposta didática explícita.

À informação de que a Terra não está no centro (do universo), muda o tom da música para uma trilha mais ritmada e ampla. O impacto musical acompanha uma mudança de encadeamento das imagens. Acontece, pois, a primeira inflexão no desenvolvimento da narrativa, no sentido de deslocá-la da chave didática-institucional ligada ao pensamento teocêntrico - para a chave experimental do filme - ligada à indagação de Copérnico:

[...] os céus são imensos em comparação com a Terra, e ficaríamos muito espantados se tal vasto mundo pudesse dar um giro completo no espaço de 24 horas, ao invés de sua menor parte, a Terra, fazê-lo. E por que não admitir que a aparência da rotação diária pertence aos céus, mas a sua realidade pertence à Terra? (DE REVOLUTIONIBUS, 1973)

Inicia-se a sequência dos planetas do sistema solar em evolução, nas tomadas mais complexas do filme, realizadas no Planetário de São Paulo. Conta-nos Ella Durst que ninguém havia conseguido filmar o Planetário até então. Julgava-se impossível imprimir o céu estrelado, tal como o vemos nas apresentações regulares. A solução adotada foi trabalhar como em um table-top invertido:

[...] sempre houve o mito de que ninguém nunca fotografou lá, que ninguém nunca tinha conseguido fotografar lá. [...] Ninguém tinha pensado em fazer um table-top invertido. Então, a própria ECA pediu autorização para o Planetário pra filmar lá e o Planetário respondeu: "não se filma aqui, não dá, é impossível". E nós falamos, "não, tem jeito de filmar". O Tassara, o Chico [Botelho], eu, a gente sabia fotografar o suficiente pra saber o jeito que dava pra fazer aquilo, que é com a câmera quadro a quadro, como se fosse um table-top invertido. Com exposição longa, muito longa.

[...] demorou, assim, duas semanas. O dia inteiro, parava pra comer e voltava. Ficava entendendo tudo do Planetário e acabamos ficando amigos do, do... porque é fascinante aquele negócio, aquela máquina, é impressionante, aquilo é o máximo. É inacreditável; então foi um prazer, uma semana de table-top invertido. Porque as cadeiras do Planetário, você deita, né, você fica deitado, com a câmera no tripé. (DURST, 2017, ANEXO III)

Com a cabeça virada para baixo e cientes de estar na linha de frente de uma experiência cinematográfica atrevida, a dupla de fotógrafos e toda a equipe do filme não escaparam de se surpreender com o resultado da empreitada: 
A primeira vez que vi aquilo - hoje seria uma besteira, com o computador a gente fazia em dois segundos - mas na época foi um luxo. A filmagem, finalmente tinha o movimento que o Marcello queria. Então, o pessoal do Planetário não acreditou. (DURST, 2017, ANEXO III)

Filmar na abóbada do Planetário rendeu o aspecto tridimensional a esta sequência e representou uma conquista técnica sem precedentes no cinema de invenção brasileiro. Essa aparência, hoje ultrapassada dadas as facilidades da animação digital, soava de fato inovadora, e não deixamos de nos lembrar da criação de outro espaço cósmico verossímil do cinema, que é o espaço sideral produzido para 2001 - uma odisseia no espaço, de Stanley Kubrick. O cosmos criado para De Revolutionibus consiste em um dos pontos altos do filme, e traz a marca da inovação em várias leituras: nas técnicas empregadas, na liberdade de adaptação do texto de Copérnico para a linguagem audiovisual e no lançamento da linguagem audiovisual para longe do educativo-didático.

O tom introspectivo da trilha sonora retorna quando Copérnico apresenta, em uma sequência de animação tomada no Planetário, sua concepção da localização dos planetas, em ordem decrescente de distância em relação ao Sol, e finalmente reserva o lugar privilegiado deste no centro do universo: “[...] no centro de tudo repousa o sol, pois quem colocaria esta luz de um belo templo em lugar melhor do que este de onde pode iluminar tudo ao mesmo tempo?" (DE REVOLUTIONIBUS, 1973). É notável como o texto de Copérnico, ao tratar de uma hipótese científica, lida o tempo todo com a dúvida e com o questionamento como símbolo cultural de uma época. Assim, o filme traduz essa inquietação na articulação de imagens que questionam e não fornecem resposta pronta: é a ideia da ciência em movimento.

Ainda com a imagem do Sol no centro do quadro, há um corte seco vertical, na trilha e na imagem: entram guitarra de Jimmi Hendrix e um do pôr-do-sol alaranjado ao fundo das silhuetas dos carros na ponte Cidade Universitária, com o claro objetivo de trazer o tema do filme para a contemporaneidade, para uma visão de mundo moderna (Fig. 85).

Esse sol é do Chico Botelho... ele adorava isso. Ele tem também nos filmes dele a ponte da Cidade Universitária... Ele adorava ver esse pôr do sol. (MOURÃO, 2017, ANEXO II)

[...] você vê que o Jimmi Hendrix começa antes de entrar o Sol. Isso é uma questão de ritmo mesmo, o ritmo exigia isso. Você cria um elemento de 
surpresa, e o público fica espantado, porque você toca lá a música medieval, de repente $P A M M$, o Jimmi Hendrix explode... Como ele fala em sol, a luz de um belo templo, é uma frase belíssima, aquilo que Copérnico imaginava você vê aqui. (TASSARA, 2017, ANEXO I)

Como uma obra de discurso aberto que procura fugir do didatismo primário, a partir deste corte para o pôr-do-sol, Mourão trabalha na montagem as relações longínquas no tempo-espaço, e no espaço. Somam-se elementos do mundo contemporâneo urbano, como os carros, o povo nas ruas e a música pop, para propor uma reflexão - via imaginação - a respeito, em primeiro lugar, das teorias geo e heliocêntricas, em segundo lugar, do embate entre a ciência e a religião, e em terceiro lugar, de como a ciência evolui. Entretanto o Sol é o mesmo, não importam as convicções, pode ser uma das interpretações para esta passagem.
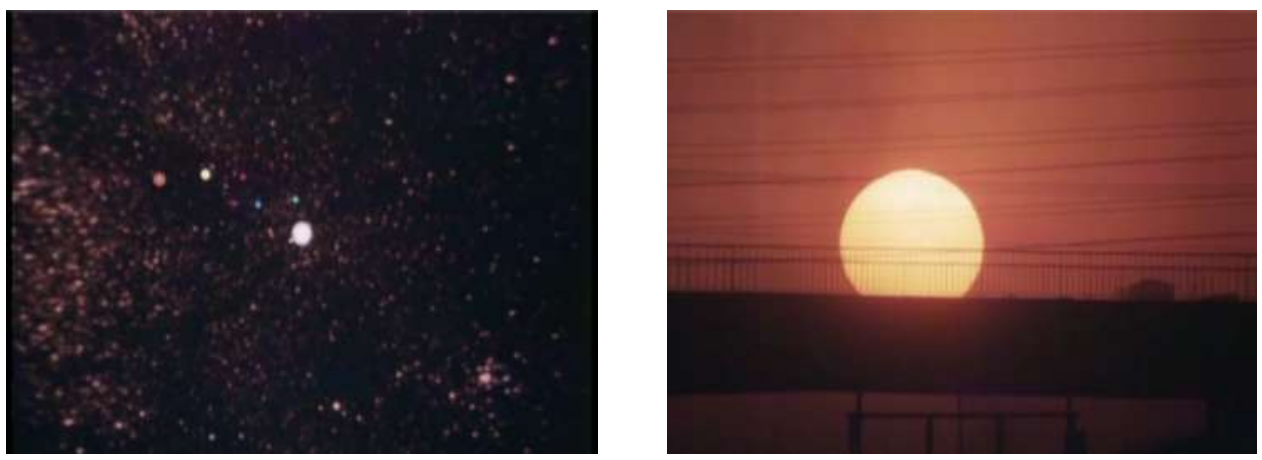

Figura 85: Corte entre as sequências do cosmos filmado no Planetário e do pôr-do-sol visto da ponte Cidade Universitária, ao som de Jimmi Hendrix. Cenas de De Revolutionibus (1973).

Questionado a respeito da idéia por trás desta elaboração imagem/som, especificamente na inserção do blues de Hendrix, Tassara argumenta que se trata de um "pulo histórico" para capturar a atenção do espectador, de um procedimento semelhante à montagem em movimento de Kubrick, quando o primata lança ao céu o osso que "se transforma" em satélite no espaço. De um modo mais abrangente a montagem de Alain Resnais em Noite e Nevoeiro (1956) propõe o mesmo tipo de associação entre as imagens documentais do passado nos campos de concentração nazistas a imagens do presente da realização do filme.

Nota-se também a longa duração do plano do pôr-do-sol, o tempo natural de sua descida, que, segundo a montadora Mourão, tem a ver com a estética do filme e com a questão do movimento, já que a montagem traz na sequência, tomadas de automóveis, motos, povo nas ruas. Para Ismail Xavier (2019, ANEXO IV), "essa descida do sol é importante por causa dos movimentos relativos, quer dizer, a Terra é que está se 
movendo, não o Sol. E em vez dos movimentos dos planetas você tem a passagem dos veículos...”.

É o início da parte final do filme, a mais propositiva e instigante do ponto de vista das questões que as imagens colocam ao espectador, sem, de forma alguma, pretender direcionar a alguma resposta. A produção, na verdade, leva à fruição de imagens que em geral nos passam despercebidas, como o movimento dos carros sobre a ponte, o centro da cidade, o pôr-do-sol. São, contudo, imagens carregadas de uma força advinda principalmente da banalidade, posta em relevo em planos elaborados e em sintonia com a trilha de som. Elas também ganham contorno de espetáculo naquilo que encerram de inexorável. A fruição, quando se dá por completo, potencializa a reflexão proposta pela obra.

O radical corte no espaço-tempo do filme inicia a sequência que comenta os desdobramentos e a difusão da ciência a partir da invenção da imprensa, em um processo de vertiginosa mudança no modo de pensar e de viver da humanidade, que desembocou, como sugere a narrativa, nas atribulações da vida moderna. Entramos, portanto, no universo da metáfora, em que o significado do objeto visto na tela extrapola sua natureza objetiva e material. Tal corte remete à sequência de 2001 - uma odisseia no espaço (1968), em que o hominídeo percebe que o osso é uma ferramenta e o lança para o céu, com corte para o satélite em órbita da Terra.

$\mathrm{Na}$ passagem filmada dentro de uma gráfica, com equipamentos funcionando a todo vapor, as imagens evocam pragmatismo. A narração pontua a impossibilidade de se atingir uma verdade absoluta a respeito dos movimentos dos corpos celestes:

\footnotetext{
O prefácio do De Revolutionibus afirma: "cabe ao astrônomo compor a história dos movimentos celestes mediante à observação atenta e hábil. Depois, voltando-se para as causas desses movimentos, ou hipóteses sobre eles, uma vez que não the é dado, de modo nenhum, atingir as verdadeiras causas, deve conceber e planejar hipóteses que, aceitas, permitam, o cálculo correto dos movimentos.

$[\ldots]$

Quanto à possível verdade, ninguém compreenderá nem afirmará nada de certo, salvo se lhe tiver sido divinamente revelado. (DE REVOLUTIONIBUS, 1973)
}

Nesse aspecto, outro ponto forte do filme são as imagens documentais do centro da cidade de São Paulo, captadas do ponto de vista de um cidadão comum, observador da paisagem urbana, com destaque para as fisionomias dos anônimos em busca da sobrevivência. E, ao falar da "possível verdade", segue-se uma longa sequência dessas 
imagens ao som de Monteverdi; novamente uma música introspectiva, colocando o espectador em posição de identificação/compaixão para com os anônimos retratados (Fig. 86).
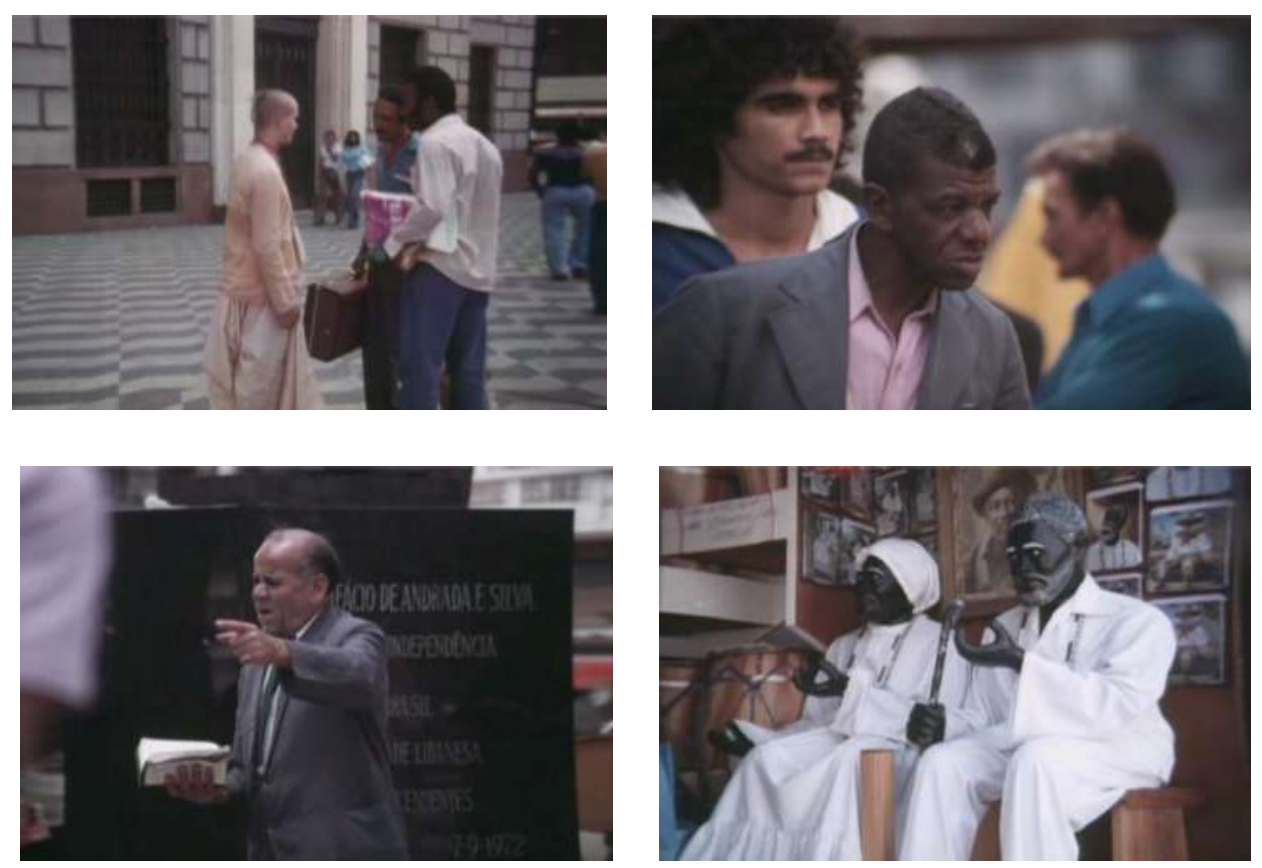

Figura 86: Cenas de De Revolutionibus (1973) em que as diversas manifestações da fé associadas às camadas menos privilegiadas da sociedade, supostamente mais suscetível ao apego às crenças religiosas, são apresentadas em contraposição à sofisticação do pensamento científico.

É no embate entre a fé religiosa e a fé na ciência que a humanidade baliza sua concepção de mundo, e o filme opta por retratar a religião concatenada com a miséria e o obscurantismo, enquanto que a ciência se relaciona com progresso e futuro. Guiada pelo pensamento teocêntrico, a civilização ocidental permaneceu dez séculos sem o questionamento necessário à compreensão da natureza, cuja consequência vem a ser o avanço tecnológico. Segundo Marcello Tassara (2017, ANEXO I), “Aqui, a intenção era mostrar como as ideias, sem ser contra, eu não sou contra nenhuma religião, mas como mostrar que a religião pode carregar preconceitos".

Não foi sem atrito e sofrimento que a teoria heliocêntrica passou a ser aceita, ampliando as investigações e estimulando o pensamento inventivo/criativo a se desvencilhar das evidências que a observação/contemplação nos provê, além de possibilitar o salto quântico conquistado pela imaginação abstrata. Isto é posto no filme em dois momentos: quando Copérnico ousa defender a troca de posições entre a Terra e o Sol, desafiando a percepção visual dos movimentos celestes, e quando se mencionam 
as figuras de Galilei, Kepler e Newton como aqueles que interpretaram e deram continuidade às indagações de Copérnico.

\begin{abstract}
As consequências políticas da teoria dele são consequências que foram muito fortes, e tal, e eu me lembro que a gente trabalhou bastante esses aspectos da, do lado, digamos assim, bastante centrado na ciência do Copérnico. Ele não escreveu o livro pra provocar poderes constituídos não. (XAVIER, 2019, ANEXO IV)
\end{abstract}

O filme se lança, na parte final, para uma visão futurista, envolvendo metalinguagem e trazendo imagens de conquistas direcionadas ao espaço sideral. Aproveitando os dias de filmagem no Planetário do Ibirapuera, a equipe fez algumas tomadas do equipamento de projeção, um monumento tecnológico que, além de ter um aspecto físico futurista, alude a uma visão de cinema fora da tela bidimensional, aponta para um cinema do futuro, o lugar da convergência de linguagens. Este equipamento, capaz de ser programado para projetar a composição do céu em qualquer data que se imagine, no passado ou no futuro, consiste em uma virtual máquina do tempo. Em composição com fotografias de radares apontados para o cosmos e com imagens das protuberâncias solares, a voz over comenta ser impossível dissociar a física da astronomia no mundo contemporâneo.

Vale lembrar que, à época de sua produção, a maior parte dos lares brasileiros ainda possuía televisores em preto e branco, e não se convivia com saturação e com disponibilidade das imagens a que nos expomos neste início de século XXI. Assim sendo, imagens das protuberâncias solares, hoje acessíveis em qualquer dispositivo móvel, representam, nessa produção, uma contribuição inigualável. A respeito da aquisição deste material, Tassara (2017, ANEXO I) relata o feliz encontro entre ciência e cinema:

\footnotetext{
Apareceu lá na ECA um dia um sujeito que estava fazendo pós-graduação no Instituto Astronômico e Geofísico da USP. E ele tinha recebido da Nasa um rolinho de filme, porque ele tinha que fazer o trabalho dele de pós-graduação medindo altura e intensidade das explosões. [...] E ele sabia da existência da Higashino, que ele fez? Ele colocou o trabalho dele, foi feito na Higashino. $\mathrm{O}$ trabalho de pesquisa em astrofísica. Então, ele media as dimensões, fez todo um cálculo da explosão do tempo de altura, do arco de fogo, ele fez esse trabalho em cima da Higashino. Ele media, projetava outro, media, assim por diante. Essas imagens são da Nasa.
}

Ao término da pesquisa, o pós-graduando já tinha as informações que the interessavam, então cedeu o rolo de diapositivo para a realização do filme. 
Das protuberâncias solares, um corte seco para a imagem do Sol poente, com as silhuetas dos carros e caminhões sob o céu laranja e o flare na lente (Fig. 87). Novamente uma guitarra de blues como trilha sonora nos destaca da introspecção, e traz a atenção para o dia de hoje. A voz de Copérnico aconselha a examinar com cuidado os fenômenos celestes para não atribuirmos erroneamente os movimentos da Terra às estrelas. E para quando quisermos investigar as coisas mais elevadas não ficarmos ignorantes daquelas que estão próximas de nós.
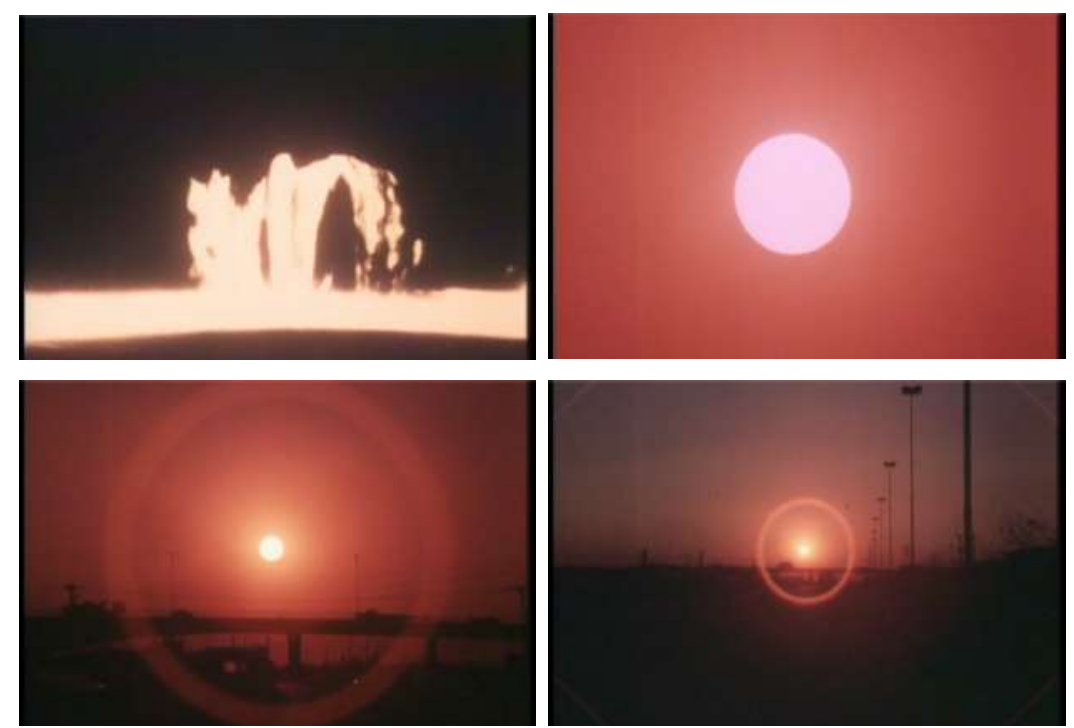

Figura 87: Cena final de De Revolutionibus (1973) - o corte seco das labaredas do sol visto pelo telescópio da Nasa para o Sol visto a olho nu; dois modos de olhar o mesmo objeto, com e sem intermédio de tecnologia.

Não obstante o rigoroso planejamento das tomadas em animação e das capturas ao vivo, a realização do filme conviveu com imprevistos, com uma parcela de caos e com surpresas, características de um work in progress, em que os elementos são trabalhados e retrabalhados em função da materialidade dos recursos disponíveis e de como vai se construindo o sentido da obra. Isso foi viável devido a um domínio técnico no terreno da cinematografia, ao profundo conhecimento do tema retratado e ao eficaz gerenciamento de recursos. Como interpretação, podemos afirmar que a maior qualidade do filme talvez seja a combinação inventiva e inusitada desses elementos que maximizam a expressividade audiovisual na livre articulação de significantes e significados. 


\section{Ray e Charles Eames abrem os olhos para a beleza do cotidiano}

Observar uma amostra do trabalho de Ray e Charles Eames ajuda a compreender como eles transferiam sua visão de mundo para sua obra como um todo, especificamente para seu cinema, e como conceberam Nicholas Copernicus.

Conhecidos como arquitetos e designers de mobília, Ray e Charles cultivavam gosto por fotografia desde muito jovens e tinham o hábito de tudo documentar. Já na década de 1940, faziam experimentos com filmes coloridos e com projeção de objetos que apresentavam transparências através da luz, como asas de insetos ou a pena de uma ave comprimidos entre duas lâminas de vidro. Suas influências mais fortes eram os filmes de Oskar Fischinger e Norman McLaren.

A atmosfera esfuziante do pós-guerra contribuiu para o espírito criativo do casal que se interessava por tecnologia, ciência e por praticamente todos os ramos das artes visuais. Todos os aspectos da vida podiam ser valorizados graças ao cuidado com os detalhes, sempre por meio da cor e da forma.

Outra preocupação dos Eames era com o sistema de ensino nas escolas. Fora do cânone das aulas expositivas, a ideia era descompartimentar as disciplinas e ajudar o aluno a fazer ligações de maneira transversal. Assim, compuseram, em 1953, uma apresentação multimídia, com projeção de imagens fixas, filmes, trilha sonora e exposição oral.

"Foi como fotógrafos e designers que os Eames tornaram-se cineastas, interessados em como e o quê veem os olhos" (KIRKHAM, 1998, p. 311). E como designers, sua curiosidade genuína, infantil, pelos objetos levou-os a fazer mais de 150 filmes em que exploravam em detalhes a cor, a forma, o volume, a superfície do objeto retratado. São exemplos desse tipo de criação as produções Blacktop, de 1952, Solar do Nothing Machine, de 1957, e Tops, de 1969 (figs. 88 a 96), em que se pesquisa todo tipo de plasticidade que as lentes da câmera podem oferecer, sobretudo no uso da lente macro. Blacktop é o segundo filme dos Eames e consiste em um estudo sobre a plasticidade das bolhas de sabão, registrado enquanto lavavam o pátio de uma escola. Charles quase não tinha experiência com cinema e, com uma câmera portátil de dezesseis milímetros, explorou as formas abstratas que a água e o sabão formam ao rastejar pelo asfalto. Ele mesmo editou as imagens, combinando as diversas tomadas com As variações Goldberg, de Bach.

Solar do Nothing Machine foi realizado de encomenda para a Companhia Alcoa 
de Alumínio, e também é um filme de exploração estética. Ray e Charles conceberam um dos primeiros equipamentos de transformação da luz solar em eletricidade. A "máquina de não fazer nada" dos Eames é uma engenhosa obra de arte cinética, maravilhosa e colorida, um brinquedo movido a energia solar, e, filmado sob a ótica joyof-life do casal, com uma trilha jazzística característica daquele período. A montagem transita do todo para as partes e leva o olhar para os detalhes mínimos que se movimentam em diferentes velocidades e interferem na percepção global. As cores e as formas celebram a ausência de utilidade em um dia de sol. Dificilmente este filme seria pensado e realizado na antiga União Soviética.
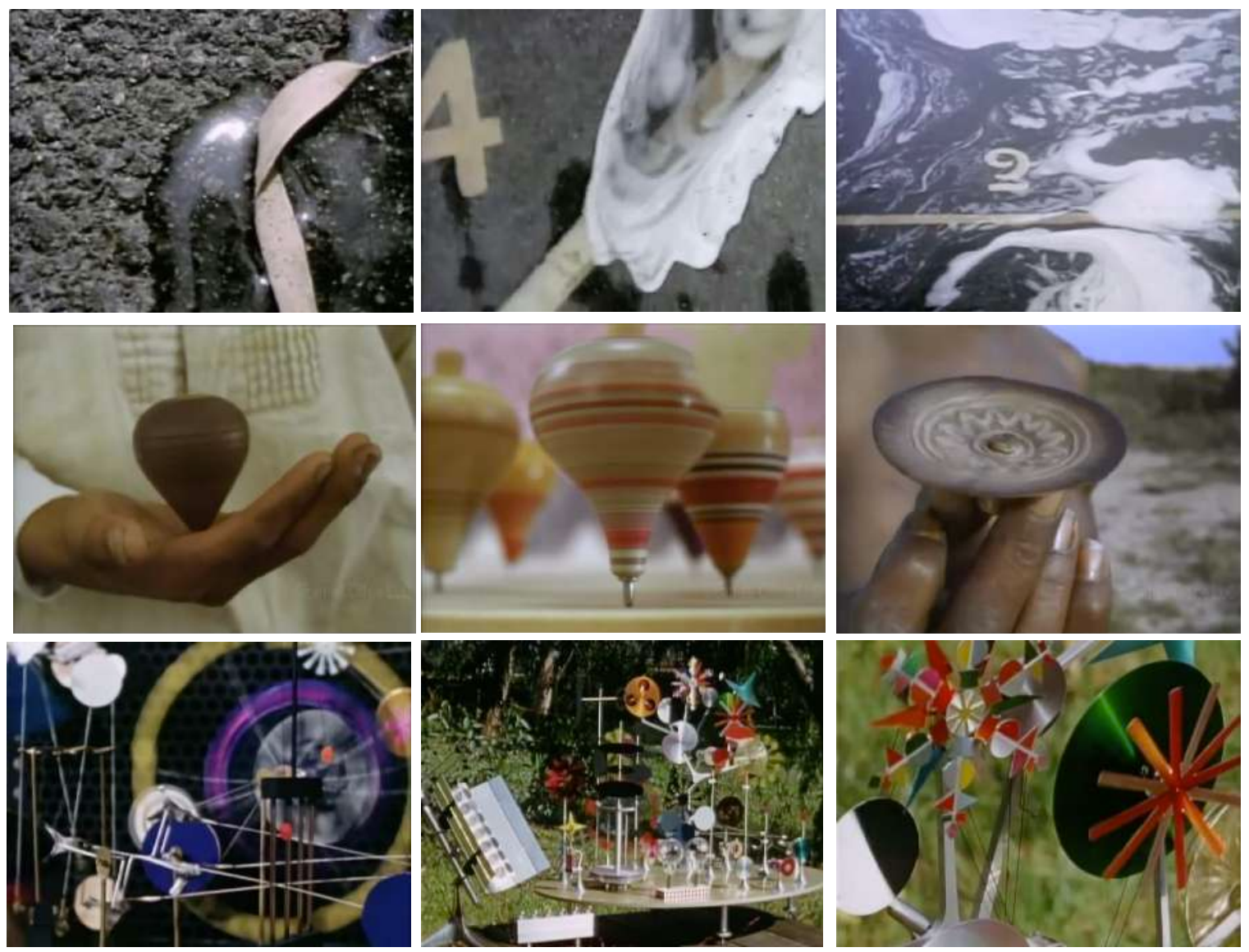

Figuras 88 a 96: Na primeira linha, imagens extraídas de Blacktop, segundo filme do casal Eames (88 a 90). Na segunda linha, imagens de Tops, produção que traz modelos de piões de todo mundo e explora a relação entre o lúdico e física (91 a 93). Na terceira linha, Solar do Nothing Machine, uma celebração da cor, da forma, do movimento e da energia (94 a 96).

Tops é o filme em que Charles retoma uma paixão de infância, os piões, e mostra ao espectador como as diferentes culturas usam o brinquedo. Da mesma forma com que fez com seus filmes anteriores, as tomadas em detalhe rendem um tributo à cor e à 
forma, e demonstram a estreita relação entre o pião e os princípios do movimento da física, embalado pela trilha sonora de Elmer Bernstein, seu futuro parceiro em Nicholas Copernicus.

O olhar dos Eames para o mundo concreto em busca de aspectos menos percebidos faz com que muitos de seus filmes não sejam considerados apenas experimentais, mas também ensaísticos. Para Charles, não se tratava de filmes, mas da tentativa de atravessar uma ideia através da lente da câmera.
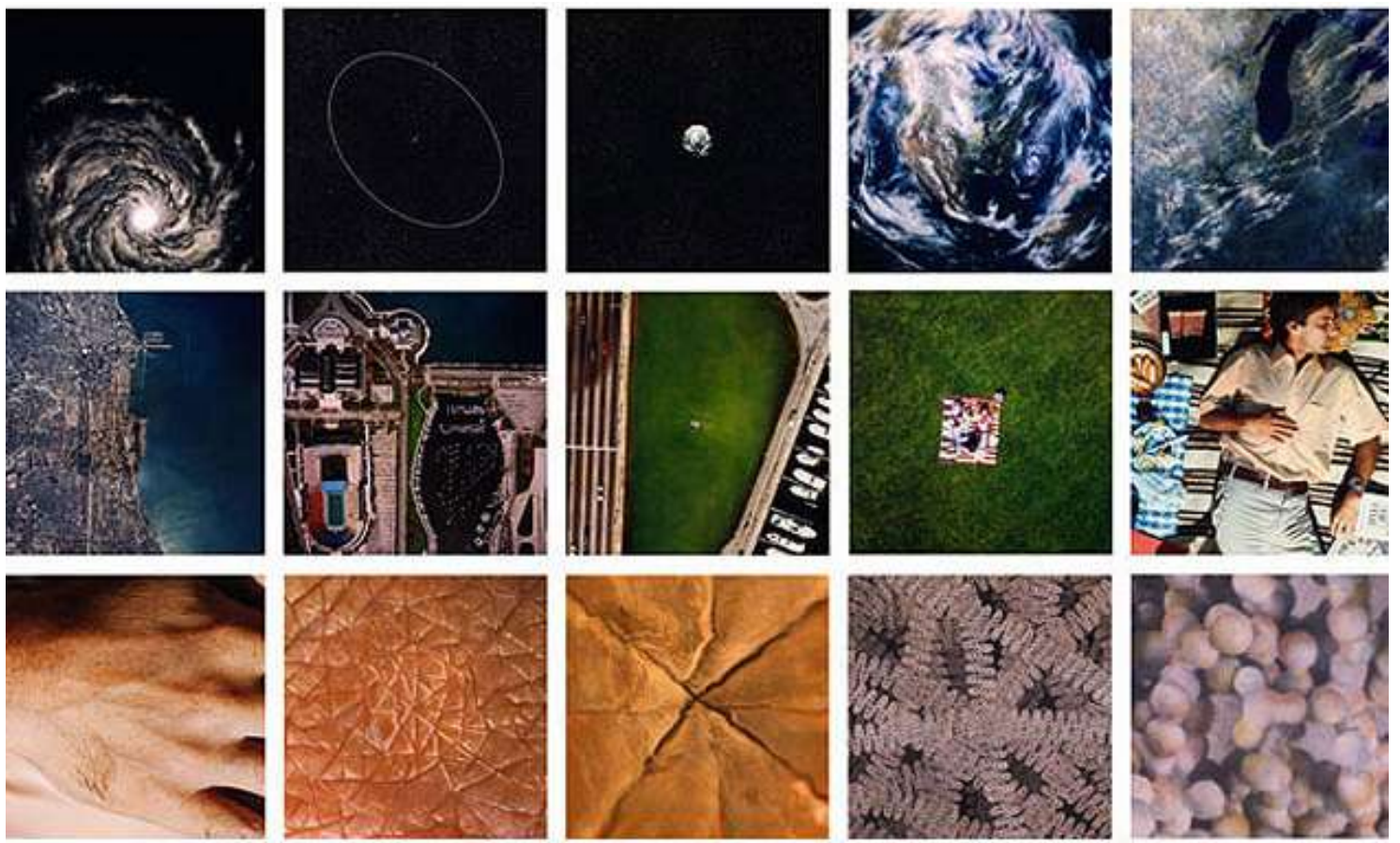

Figura 97: Em Powers of Ten (1977), a câmera afasta-se do casal em potências de dez, até atingir o ponto mais distante do conhecimento humano, 100 milhões de anos luz, ou $10^{24}$ metros. Na volta, a câmera "entra" na pele do homem e se aproxima até o próton de um átomo de carbono.

O discurso proposto pela montagem nesses e em outros filmes agencia a dialética entre a estética e o funcionalismo, designers que são, e orienta o olhar, buscando no ritmo um sentido de "coerência", um racionalismo que advém da sinestesia. O uso do raccord do movimento é recorrente, bem como das rimas visuais, sobretudo nos filmes que, em princípio, não veiculam uma mensagem específica, mas representam os objetos como esculturas abstratas.

Além desses, Powers of Ten [Potências de 10], de 1977, é talvez o filme mais conhecido da dupla, em que a aproximação com a ciência dá-se na primeira leitura (Fig. 97). Graças a recursos estritamente cinematográficos, zoom-in e zoom-out, o casal 
coloca o espectador como cidadão do universo, na viagem que vai da escala humana para a galáctica, e na volta chega até a escala atômica. A referência central é a humana, dada pelo casal que faz piquenique na borda do lago Michigan.

Trabalhando como cineastas independentes, Ray e Charles realizaram vários filmes sob encomenda, entre estes, a série para a IBM (International Business Machines) sobre conceitos matemáticos e computacionais, como Simetry, Topology e Introduction to Feedback. Sempre com recursos tecnológicos de ponta ou desenvolvendo tecnologia para a realização, as produções para a IBM trouxeram o olhar dos Eames para a resolução de problemas, o que eles concebiam como uma forma de mudança social. Foi para a IBM que produziram Nicholas Copernicus, em 1973, para as comemorações dos 500 anos do nascimento do cientista.

O curta-metragem de onze minutos assemelha-se, em uma primeira leitura, à composição que vimos em De Revolutionibus, na qual imagens estáticas são alternadas com tomadas ao vivo, apresentando temas relativos a Copérnico. A primeira diferença sensível dá-se no plano da produção: a equipe dos Eames viajou à Europa para captar das fontes primárias seu material bruto. A segunda, também no plano da produção, refere-se à trilha musical, composta exclusivamente para o filme pelo músico Elmer Bernstein, parceiro em todos os filmes precedentes.

$\mathrm{Na}$ descrição, o filme inicia com a trilha sonora sobre os letreiros e já remete a um determinado contexto histórico no passado - a baixa Idade Média. Composta nos moldes das cantigas da época, trata-se de um belíssimo pastiche, executado com orquestra de câmara de instrumentos antigos. Vê-se, então, um velho caderno com capa de couro. Observado por vários ângulos, a montagem em fusões aos poucos revela detalhes cada vez mais próximos do objeto, sua textura sobrevivente aos séculos, uma celebração do artefato físico (SCHULDENFREI, 2014, p. 142). Em tomadas com pouca profundidade de campo, apenas uma pequena parcela da imagem está em foco, o que orienta o olhar do espectador para um detalhe de cada vez.

Em seguida, um grupo de estudantes aprecia um manuscrito original desta encadernação, a caligrafia, as bordas gastas das páginas, os gráficos e diagramas dos cálculos de Copérnico, em uma narrativa fotográfica que nos leva para o interior da mente do cientista. A imagem do esquema heliocêntrico surge em uma série de jumpcuts, cada vez mais próximos, até que se chega à palavra SOL (Fig. 98). 

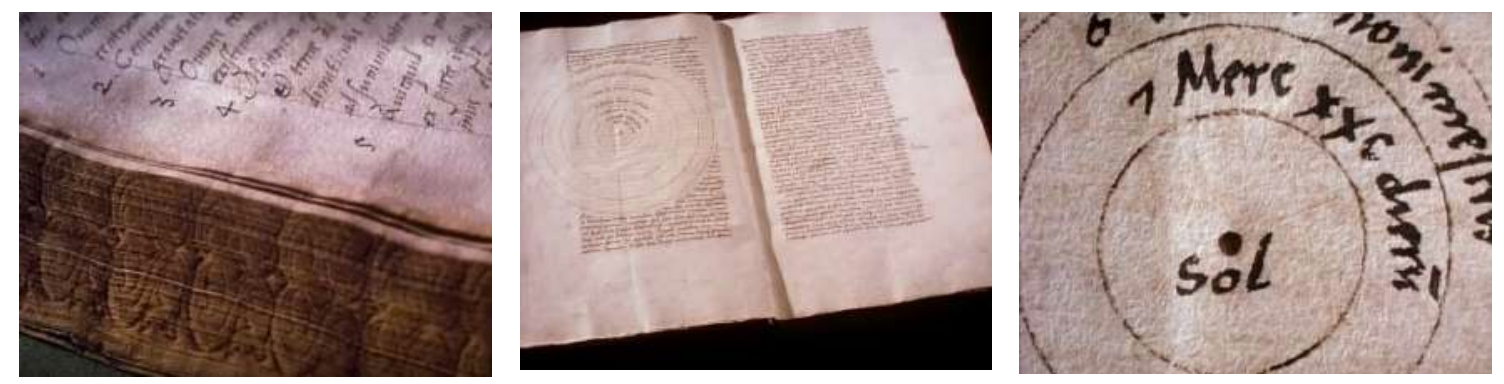

Figura 98: Cenas de Nicholas Copernicus (1973). A atenção para o detalhe no objeto livro, seguida de planos cada vez mais próximos, dirige o olhar para centro da questão copernicana.

Ao trazer como primeira imagem o manuscrito de Copérnico, o filme valoriza o aspecto cultural da produção científica em uma espécie de veneração, e coloca o espectador em contato com objetos únicos.

Em corte seco, surge uma paisagem campestre: árvores, clareiras, montanhas ao fundo. A sequência transita do universo intelectual para o natural, possível sugestão de que a elaboração científica deriva da observação do mundo. Da natureza à obra humana, a sequência seguinte migra para planos em contra-plongé de arcos góticos e esculturas cristãs na cidade de Torun, na Polônia. Em um dos poucos momentos de locução em off, a contextualização histórica da anexação da Prússia pela Polônia, pouco antes do nascimento de Copérnico, conta-nos de um período de paz na Europa. Visitamos as locações onde ele viveu, estudou e trabalhou na Cracóvia, em uma progressão que vai dos grandes planos gerais aos detalhes arquitetônicos e à busca de formas e de texturas. Retém-se a sensação de antiguidade das coisas, tal e qual um turista observador e desejoso de não perder nenhum detalhe. A espacialidade dessa sequência articula, além do ambiente físico, a cultura-berço que propiciou a atividade de Copérnico, e das gerações de pensadores, artistas e cientistas do Renascimento. Assim, mostram-se imagens externas da arquitetura de igrejas e universidades, e internas, trazendo a introspecção e, finalmente, a produção cultural.

Com o advento da imprensa, as ciências e a astronomia puderam se desenvolver sem freios, graças à divulgação do conhecimento, antes reservado à Igreja. Isso não significa que a Igreja tenha perdido seu poder, pelo contrário. Sua força gerava nos homens de ciência o desconforto de estarem subvertendo uma ordem há séculos estabelecida. Copérnico é exemplo desse conflito intelectual.

A progressão do pensamento teocentrista para o humanista é retratada pela familiar iconografia dos desenhos medievais, plenos de signos, com linhas de contorno 
e sem perspectiva, seguidas das imagens dos complexos desenhos de anatomia e de botânica, em uma estética mais realista. É um comentário a respeito do ressurgimento do interesse pelo conhecimento ao final da Idade Média, um momento em que a mediação divina começa a sair de cena.

O período em que Copérnico completou sua formação na Itália, em Ferrara, também é ricamente ilustrado, costurando imagens do interior de uma catedral, ao som de canto gregoriano, com imagens externas, e fundindo-se com imagens do interior de uma biblioteca e, novamente, de livros em super-close-ups. Ou seja, presenciamos, pela montagem, o movimento de zoom-out ao sair de um espaço e um zoom-in chegando cada vez mais próximo do texto, até atingitr o espaço do isolamento da letra, da introspecção. São essas imagens do texto de Copérnico impressas em livro, não mais em caligrafia, que retomam o motivo inicial do filme, traçando um arco temporal por meio da montagem, agora com outra força: o cinema faz hoje o que a imprensa fez outrora. Há um paralelo entre a oportunidade oferecida pela imprensa e pelo cinema: se, no passado, a imprensa propiciou difusão do conhecimento e acesso a ele, é o cinema quem continua hoje esta tradição.

Ao longo do filme, o esquema proposto desde o início mantém-se, sem surpresas, trazendo paisagens, monumentos, livros, caligrafia, enfim, naturezas mortas em desfile, sem recorrer a explicações textuais e acionando a inteligência visual do espectador, traço fundamental na filmografia dos Eames (Fig. 99). Cientes de que o filme integra uma grande exposição, é compreensível que a dupla objetivasse colocar na tela elementos que pudessem ser combinados com o restante da mostra, permitindo ao visitante tecer relações por si só.
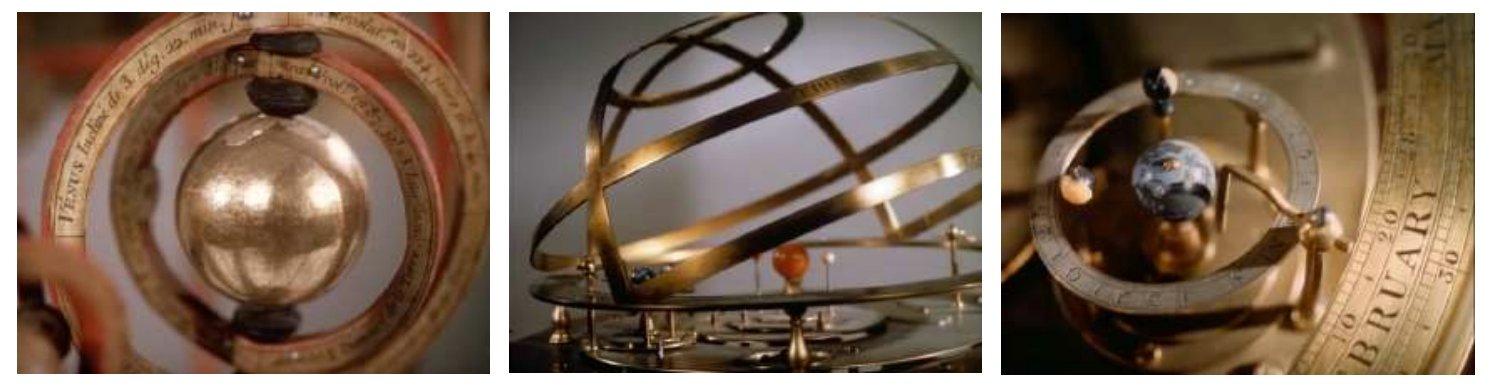

Figura 99: À maneira de muitas de suas produções anteriores, em Nicholas Copernicus (1973), o gosto pelo detalhe revela o deslumbre dos Eames com o virtuosismo e a precisão da forma, algo que espelha a própria produção da dupla como designers.

Assim como a dupla Eames, com seu genuíno interesse por uma multiplicidade 
de temas - do circo à astronomia -, o filme trata da vastidão do espírito renascentista, em que o indivíduo era ao mesmo tempo pintor, escultor, músico, médico, advogado, filósofo, e, como Copérnico, também padre (cônego).

Nicholas conta com vasto material de pesquisa, filmagem em locações, trilha original e uma equipe bastante familiarizada com a técnica cinematográfica. É um filme que investiga um momento histórico fazendo uso de formas, do design e da textura, construindo uma atmosfera.

Alguns questionamentos são propostos, mas de um modo contemplativo; o filme incita a compreensão a partir da observação. Podemos interpretar que não há desconforto nem sobressalto. Não obstante a plasticidade e o regime de associações proposto na montagem, a obra resulta monótona em certa medida; a locução monocórdica e a música com poucas variações contribuem para isso.

O público que desconhece a obra de Copérnico pode não compreender o impacto da sua contribuição como algo que originou a revolução científica moderna. Mas isso é devido a uma característica dos filmes de exposição dos Eames: sendo parte de um conjunto, não têm obrigação de explicar, mas de ambientar, contextualizar. Mais do que entregar as ideias científicas de Copérnico, o filme as encaixa no contexto de sua biografia.

Ao final, a produção sumariza a biografia e as contribuições de Copérnico em uma sequência de montagem rítmica. Os primeiros manuscritos, a obra impressa, seu reconhecimento através dos tempos sob a forma de moedas, selos, notas de dinheiro, todas com sua fisionomia, uma prova de seu valor e da dignidade de sua pátria.

Existe no curta do casal Eames uma diferença crucial em relação ao de Tassara: enquanto este investe na imaginação e numa espécie de "viagem no tempo" simulada pelo tipo de material filmado, pela montagem (com auxílio de letreiros com datas passadas) e pelos tais "pulos históricos", o curta dos Eames se compraz em permanecer sempre no presente: nos resquícios dos manuscritos originais, nas paredes e pedras da Cracóvia de 1973, ou seja, o espectador em momento algum é convidado a viajar no tempo com o filme. 


\section{Capítulo IV}

\section{Evolução técnica e poética da animação científica}

Neste capítulo, trataremos das técnicas da animação realizadas em película, seja em desenho animado tradicional, seja em infográficos animados, seja em animação de fotografias. Interessa-nos compreender, no universo do cinema científico, quais seus limites, como se dá sua evolução técnica e poética, quais suas aplicações e em que aspectos a animação é mais eficaz. A seleção de filmes a seguir demonstra a variedade de usos da técnica em diversas disciplinas.

As técnicas do cinema de animação revelam a melhor de suas qualidades, o poder de materializar o que é abstrato e/ou invisível e aquilo que só a mente é capaz de elaborar no tratamento dos fenômenos da natureza, da vida e da sociedade. Também representa um considerável reforço para as novas teorias científicas e um valioso instrumento quando o objetivo é o ensino, a difusão e o debate.

Há diversos pontos de conexão entre o cinema científico e o cinema de animação, começando pela necessidade da decomposição do movimento para sua compreensão. Ao desenvolver métodos de pesquisa para congelar um determinado momento de uma ação, Muybridge e Marey fornecem matéria-prima modelo a partir da qual gerações de artistas podem exercitar o desenho e a ilusão do movimento. A decomposição do movimento investigada por Marey e Muybridge no final do século XIX permanece como objeto de consulta ainda hoje.

Mesmo que o cinema científico seja, em sua essência epistemológica, um documento, é preciso reconhecer que há um limite no registro da realidade com uma câmera de filmar, para além do qual um outro tipo de figuração (representação) se faz necessário. É aí que as técnicas da animação e do trabalho artístico cumprem o papel de reiterar ou explicar um fenômeno cognitivo, uma teoria do conhecimento ou um conceito estrutural. A animação também permite que se visualizem postulados e hipóteses em relação aos objetos de estudo.

Há três métodos principais no emprego da animação no cinema científico:

1. A animação fotográfica na técnica usada do quadro a quadro ou time-lapse, em eventos de longa duração (em relação à escala de tempo da percepção humana). É uma animação de investigação cujo resultado encaminha informações novas, em geral 
surpreendentes. Essas imagens podem ser submetidas a novos processos, por exemplo, na ampliação ou no reforço do contraste, e servem para análise a posteriori. Mas a deformação do tempo em favor da visualização distancia-nos da realidade do evento, torna-o esteticamente fantástico e aproxima-o da ficção. Filmes como $O$ crescimento dos vegetais, de Jean Comandon, tratam a condensação do tempo de modo a evocar o movimento imanente das plantas, conferindo-lhes um comportamento próximo ao animal.

2. A animação de infográficos ou ilustrações animadas, que trata de um conhecimento já estabelecido ou em processo. Podem ser inserções gráficas sobre imagens já filmadas com informações não contidas no filme, dados numéricos, uma linha curva que mostre a evolução de um movimento etc. Também são usados maquetes e objetos, e é bastante útil em comunicações para congressos, divulgação e proposição de hipóteses. Trabalhase, portanto, com a difusão de um saber que se submete à reflexão e à revisão.

3. A animação computadorizada, que se ramifica ainda em dois casos de uso: como infográfico ou como visualização de um fenômeno em três dimensões (a simulação de uma hipótese impossível). Este último método será tratado no Capítulo V.

Nos dois primeiros casos, a adesão pela via do processo cognitivo cerca o espectador de evidências visuais, muitas vezes desafiando o sentido racional. Da animação computadorizada para simulação, há o estímulo para o debate entre estudiosos da mesma área científica. $\mathrm{O}$ apelo à sensibilidade é o caminho da estética, trabalhada em função da otimização da transmissão de uma mensagem do saber. A animação científica não é apenas uma técnica; a disciplina e sua representação não se dissociam no filme. Não é raro que realizadores de cinema - na animação é bem frequente tenham iniciado suas carreiras nas engenharias ou nas ciências exatas ou biológicas. Os exemplos de cientistas ou engenheiros que migraram de sua formação original em direção ao cinema repetem-se pelo mundo afora, nas figuras de Jean Painlevé e Marcello Tassara, entre outros.

Outra consideração é o fato de que as animações científicas, em muitos dos casos, serem inserts em filmes captados ao vivo; constituem-se, portanto, como fragmentos que devem ser analisados em conjunto com aquilo que vem antes e depois do processo cognitivo. $\mathrm{O}$ uso de trucagens substitutivas, explicativas e demonstrativas ocorre principalmente nas obras destinadas à comunicação de grande público - dos congressos à sala de aula, à TV ou à internet. A versatilidade da animação, das formas 
de representação que ela enseja, possibilita seu uso em todos os campos do conhecimento.

A matemática é uma linguagem em si e nasceu, entre outros, do desejo do homem de compreender o mundo. É considerada a ciência mais conceitualizada, a mais naturalmente desprovida de imagens, terreno da abstração por excelência. Da mesma forma que se criou o alfabeto, simplificado e estilizado, a representação na matemática também evoluiu conforme o progresso da compreensão do mundo. É também uma das disciplinas mais complexas em termos de representação e de visualização espacial. Como consequência do seu status de abstrata, a matemática costuma ser a disciplina do insucesso, a matéria da infelicidade para a grande maioria dos estudantes.

Uma imagem que se cria é apenas uma possibilidade em meio a tantas outras. Mostrar não é o mesmo que demonstrar, cujo rigor absoluto costuma se traduzir em uma certa austeridade nas formas. O cinema de animação contribui para tornar a absorção da matemática mais natural pela inserção do movimento, da música e da cor. O cinema de animação manifesta o sincretismo nas relações que se estabelecem à disposição de um objeto e de uma subjetividade.

A seguir, alguns filmes escolhidos por seu pioneirismo ou por aspectos singulares serão comentados de modo a evidenciar o potencial da animação e suas diferentes configurações, conforme o contexto em que aparecem.

\section{Mathematische Trickfilm (1910)}

No final do século XIX, o ensino da geometria passou a ser criticado por ser muito atrelado aos elementos da geometria euclidiana. Havia uma falta de conexão entre as representações bidimensional e tridimensional, além de certa rigidez e imobilidade nas figuras geométricas. Havia uma noção de que, com figuras móveis, a geometria poderia ser simplificada. O prof. Ludwig Münch, filólogo, físico e professor de matemática, idealizou filmes de animação logo após a virada do século, mas apenas em 1910 o primeiro deles, sobre o teorema de Pitágoras, ficou pronto (Fig. 100). Münch recebeu ajuda de parentes e ex-alunos para concluir os demais, totalizando trinta produções. Alguns dos temas que interessavam ao professor-cineasta eram: a transição de diferentes seções cônicas entre si ("metamorfose"); rolagem do círculo de curvatura 
ao longo de uma curva; representação do movimento planetário depois de Ptolomeu e Copérnico.

Antes da distribuição em escolas, Münch fez projeções de Mathematische Trickfilm a preços populares para financiar os demais filmes. A reação do público foi positiva de um modo geral, e um dos jornais da época relatou:

[...] no sonho dos cérebros dos alunos torturados, o teorema de Pitágoras ganhou vida. [...] círculos, tangentes, hipérboles, parábolas relacionam-se em metamorfoses complicadas. Uma área da matemática que quase pode ser chamada de transcendental. O que nenhum olho humano jamais viu, o que nem mesmo os professores universitários de matemática podem imaginar com clareza foi visto em uma realidade impressionante na tela branca. [...] O valor desse material é incomparável, especialmente para o campo da matemática superior, chave para todas as maravilhas e sucessos da tecnologia da ciência da Terra e do céu. (apud KITZ, 2013, p. 146)
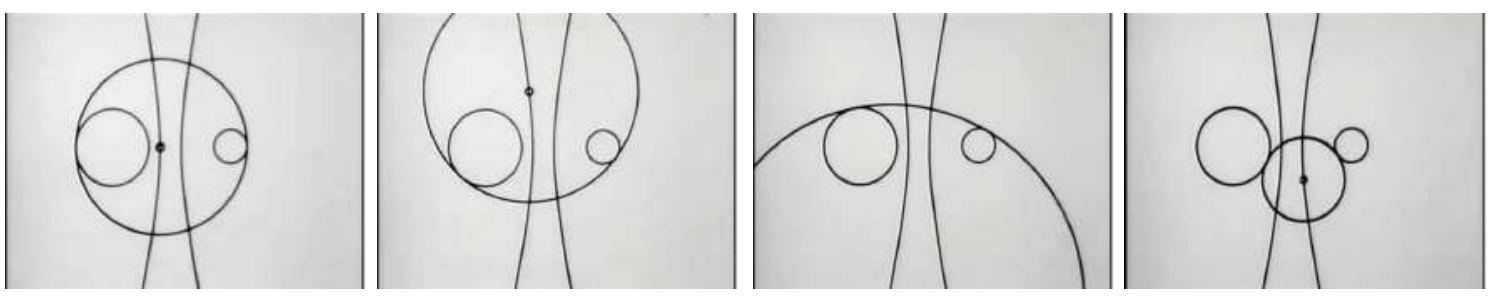

Figura 100: Sequência de imagens extraída de Mathematische Trickfilm (1910). Por meio do movimento, Ludwig Münch consegue emular um espaço tridimensional a partir de figuras geométricas bidimensionais. A animação oferece uma maneira nova de olhar a relação entre ponto, reta, curva e plano.

Os filmes foram distribuídos nas escolas de Frankfurt, mas o cinema ainda não era de fácil manuseio, e muitas escolas não eram equipadas com projetor. Havia também acidentes, como o filme que rompia ou pegava fogo. Hoje em dia, há cerca de vinte dos trinta filmes de Münch arquivados no Instituto Alemão de Cinema em Wiesbaden.

O trabalho de Münch revelou-se pioneiro em dois sentidos: no processo de produção de um desenho animado, propriamente dito, com a determinação dos desenhos-chave para posterior intervalação das demais etapas; no grafismo próprio das imagens geométricas, que são tratadas esteticamente na exploração do campo e no extracampo cinematográficos. Seu trabalho foi um prenúncio do que seria mais tarde, nos anos 1920, o cinema de vanguarda e o experimentalismo gráfico. Münch também antecipa o esquematismo característico dos primeiros trabalhos em computação analógica de John Whitney, nos anos 1960-70. 


\section{The Einstein Theory of Relativity (1923)}

No início do século XX, a teoria da relatividade trouxe uma visão inovadora das leis da física e introduziu a quarta dimensão ao estudo da matéria, mudando irreversivelmente a concepção de tempo. Ao observador, ela conferiu um lugar de destaque na compreensão de fenômenos, dada a diferente percepção conforme os pontos de vista. A teoria da relatividade de Einstein, publicada em 1905, abriu um campo ilimitado de especulações de toda ordem, inclusive filosófica, e ampliou espaço não apenas para inovações tecnológicas, mas para a abtração, a imaginação e a fantasia. Contudo, sua complexidade distanciava-a do grande público.

Até então, a física clássica apresentava-se naturalmente compreensível e visualmente representável, seja para a comunidade científica, seja para o público geral. Seu aspecto concreto e sensível não constituía barreiras ao entendimento de uma série de fenômenos ligados às experiências cotidianas - conceitos de velocidade, gravidade, hidráulica, calorimetria, óptica, são exemplos dessa física "sensível”.

É nesse momento que a arte comparece como aliada da ciência para traduzir, materializar e trazer beleza para conceitos como "o espaço é dobrável" ou a "trajetória curvilínea da luz", que extrapolam o senso comum. O senso comum costuma ser, aliás, um obstáculo para a compreensão da realidade. Buscando tornar essa nova visão da física mais próxima do público, Hanns-Walter Kornblum realizou em 1922, na Alemanha, o documentário Die Grundlagen der Einsteinschen Relativitäts-Theorie, ou Os Fundamentos da Teoria da Relatividade de Einstein, em que elabora visualmente alguns conceitos da teoria de Einstein, utilizando para isso algumas cenas em animação. O filme de Kornblum é um caso bem característico do emprego das técnicas de animação na criação de imagens impossíveis de serem vistas na escala espaço-temporal humana. A animação se mostra eficaz nesse tipo de formulação, especialmente quando o objetivo é compreender a partir de uma hipótese e tornar visíveis ideias abstratas. $\mathrm{O}$ filme estava desaparecido e foi recuperado em 2005 pelo British Film Institute.

Entre as décadas de 1910 e 1920, a indústria do desenho animado expandiu-se substancialmente graças a uma série de desenvolvimentos técnicos, à otimização de mão-de-obra (divisão de tarefas), e a uma visão administrativa mais voltada à sua exploração comercial. Os irmãos Dave e Max Fleisher ${ }^{29}$ já tinham um estúdio de animação estruturado quando se reuniram com o astrônomo e escritor de ciência

\footnotetext{
${ }^{29}$ Criadores dos personagens Coco Clown, Betty Boop e Popey, e que patentearam vários instrumentos para facilitar a animação, entre eles, o rotoscópio.
} 
popular Garret Putnam Serviss, e se engajaram no desafio de produzir um filme a respeito da teoria da relatividade. Inspirados pelo filme de Kornblum, os Fleischer realizaram um curta-metragem silencioso de vinte minutos que chegou a ser elogiado pelo próprio Einstein, por dar um aspecto visual às suas ideias. Eles não apenas se inspiraram no filme de Kornblum, como utilizaram várias de suas cenas, especialmente as animadas. Sob a coordenação de Serviss, realizaram The Einstein Theory of Relativity, de 1923, que é tão engenhoso e imaginativo quanto bem-humorado.

O filme mostra aspectos da vida cotidiana, exalta os "milagres" do progresso tecnológico e demonstra que tudo é observado do ponto de vista de quem está na superfície do planeta. O narrador propõe então que o espectador experimente uma posição diferente, a partir de um lugar fora da Terra. Em uma das melhores cenas, o piloto que conduz esta experiência coloca sua indumentária e entra em um imenso canhão que o dispara em direção ao espaço, em uma simulação cômica semelhante ao lançamento do foguete em Le voyage dans la Lune, de Georges Méliès, (1902). À medida que o piloto se afasta, o planeta diminui, em uma sequência que antecipa em 23 anos a primeira imagem real que tivemos de nosso planeta visto do espaço, em outubro de 1946. Lá do espaço cósmico, ele demonstra o conceito da relatividade de escala, de direção e de movimento, o que representa um salto imenso rumo à compreensão dos fenômenos do universo.

Os intertítulos são enunciados frontais de um narrador invisível ao espectador, como se fosse uma voz em of, sempre propondo e questionando para, após a verificação visual de um fenômeno, extrair-se uma conclusão (Fig. 101).

O comentário fílmico em excesso pode fechar o senso das imagens e impedir uma interpretação. Entretanto, nesse filme, o hermetismo do conteúdo é trabalhado com clareza e objetividade, sem termos técnicos complicados e recheado de exemplos. "Essa teoria abriu um campo ilimitado para especulação, sonhos e fantasias." (THE EINSTEIN THEORY OF RELATIVITY, 1923). Esta sentença sintetiza em boa medida o que buscamos comprovar neste estudo sobre a linguagem cinematográfica no campo da ciência.

Os Fleischer lançam mão de todos os recursos de trucagem e animação disponíveis na época, desde o desenho animado 2D até o stop-motion, passando por registros de experimentos em alta velocidade. O filme também é inventivo na criação de exemplos extraídos do cotidiano ao tratar das variadas grandezas que se sujeitam de alguma forma ao conceito de relatividade: espaço, tempo, distância, velocidade, objeto, 
tamanho, cor etc.
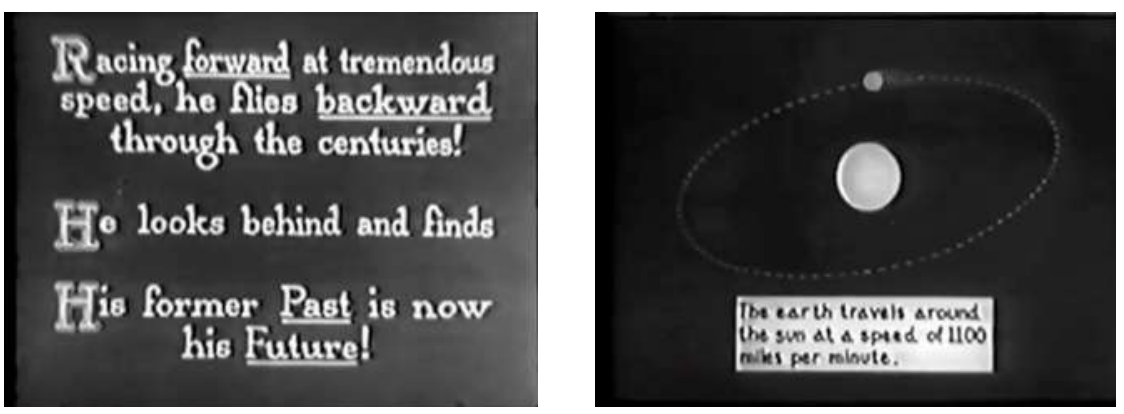

Figura 101: Cenas de The Einstein Theory of Relativity (1923). Intertítulo e animação de uma hipótese surpreendente: a viagem ao passado.

\section{Ronde carrée (1961) e Notes sur a triangle (1966)}

René Jodoin, o fundador do National Film Board do Canadá (NFB), cuja ligação com o cinema experimental e de vanguarda alimentou as produções, celebra o movimento, a música e a dança por meio do ballet colorido das formas geométricas dispostas na tela preta: palco da cena que exibe alegremente as relações espaciais entre suas medidas. Seus filmes Notes on a Triangle (figs. 102 e 103), e Ronde Carée (figs. 104 a 106) não correspondem exatamente ao que chamamos de filme pedagógico ou educativo.
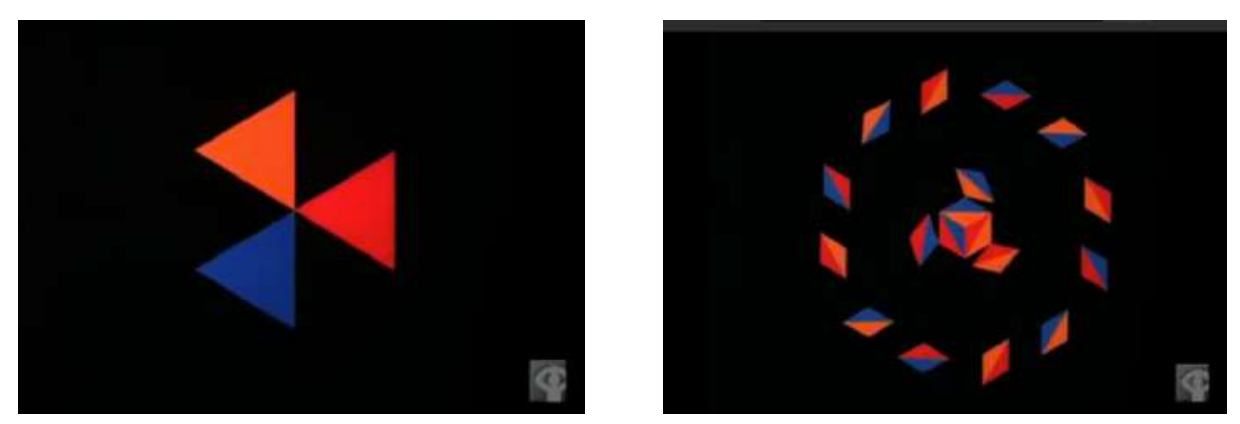

Figuras 102 e 103: Notes sur a Triangle (1966), o balé dos triângulos.

Esses filmes não têm a pretensão de ensinar ou mostrar fórmulas. Fazem parte de uma produção talhada em torno de conceitos matemáticos, mostrando as peculiaridades de formas tão simples e tão ricas em possibilidades de relações. No entanto, não há números, escalas, desenhos explicativos. A matemática está por trás das formas, mesmo no modo de produção, em que cálculos complexos possibilitaram a precisão dos movimentos no ritmo exato da melodia, sempre acompanhado por um tema 
popular canadense.
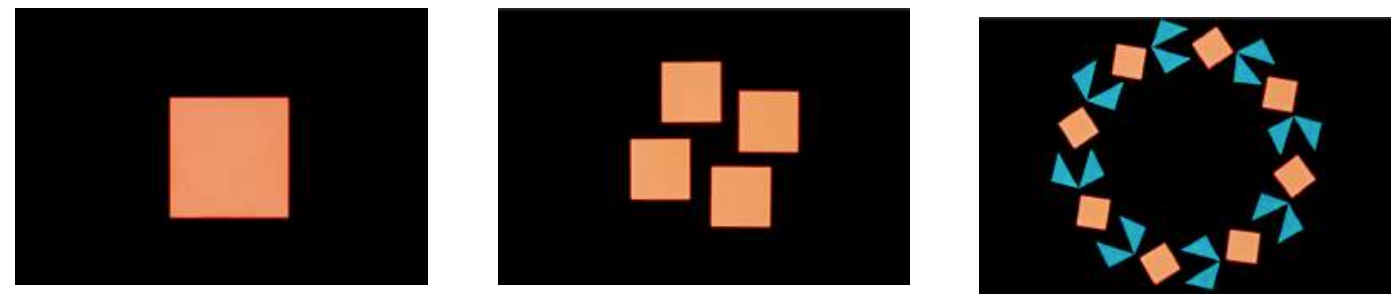

Figuras 104 a 106: Ronde Carrée (1961), o balé dos quadrados que executam danças circulares.

Sem contar com uma narrativa definida, esses filmes são abstrações, assim como a matemática o é, e a escolha da dança que costura o grafismo colorido ao tema musical popular evoca a conexão entre a vida e os sentidos em uma alegre celebração.

\section{Rythmetic (1956)}

Norman McLaren, o mais célebre realizador do National Film Board do Canadá, também fez várias incursões no cinema de animação com finalidade de ensino/científica. $\mathrm{O}$ mote central de grande parte de sua obra consiste em pesquisas no cinema, ou seja, experimentos com e sem câmera de filmar. Todos os tipos de registro em película que se possam elencar foram imaginados e executados por McLaren na busca da expressão máxima do cinema. O caráter científico intrínseco à obra de McLaren, do qual o conhecimento resulta de incansáveis pesquisas, é a matéria própria da epistemologia do cinema, neste caso entendido como conhecimento e como ciência.

Não apenas a imagem, mas a pesquisa com som em seu aspecto visual levaram McLaren a sofisticadas composições rítmico-melódicas a partir do desenho direto na película. Um exemplo é Pen Point Percussion, que mostra o caminho que o som percorre desde sua emissão até o registro na banda de som do cinema.

Em Rythmetic, McLaren brinca com a aritmética em um jogo cômico e percussivo: desde os letreiros iniciais, o jogo de letras já se dá de maneira cartesiana, com exatidão espacial. Esta aparente rigidez do início do filme é o tom dominante até o final. Aparente, pois trata-se de uma estratégia para engajar o espectador em uma suposta seriedade - o universo dos números - para, paulatinamente, expor a relação divertida que os números podem ter entre si, entre o espaço e entre o som.

O filme começa com os números de 1 a 5 formando o desenho de um losango. Em seguida, os espaços entre os números são preenchidos com sinais de,+- e =, 
trabalhando-se a matemática, qual uma imensa equação. O espectador acompanha os cálculos, inicialmente lentos. Aos poucos, torna-se impossível conferir a sequência de operações, que completam a tela em ritmo alucinante. Os símbolos matemáticos, algarismos e sinais não são rígidos, eles dançam, metamorfoseiam-se, empurram-se uns aos outros, têm personalidade expressa pelo modo como se movem, até se obter a correção no cálculo de uma sentença. Em um dado momento, tem-se mesmo a impressão de se ouvir a um sapateado sincronizado com o deslocamento frenético dos algarismos (Fig. 107).
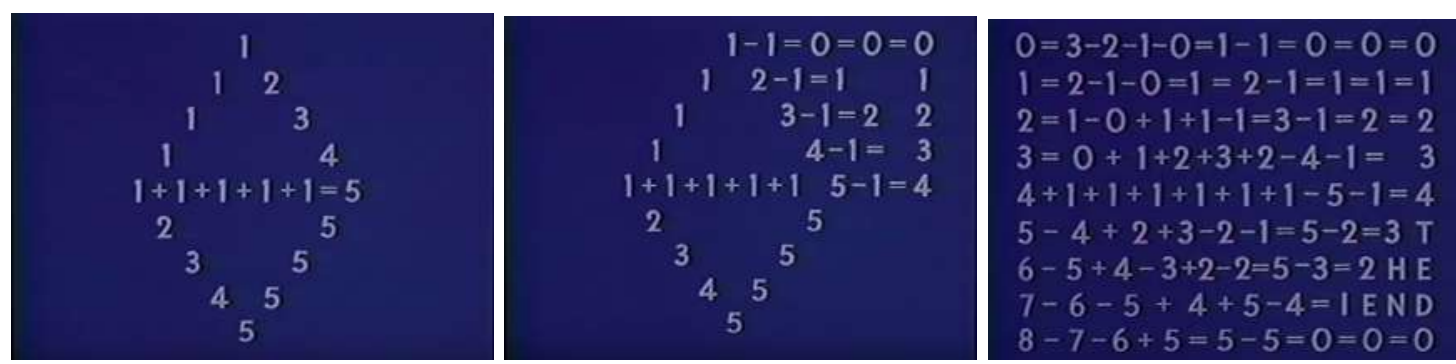

Figura 107: Imagens colhidas de Rythmetic (1956), animação em que o ritmo cômico e dançante dos números humanizam a matemática. Note no canto inferior direito da terceira imagem o letreiro The end.

Outros filmes de McLaren tratam das relações matemáticas de uma forma transversal, como em Synchromy, que já traz no nome a justaposição entre "sincronia" e "cromia", conceitos científicos atrelados à propagação de ondas: mecânica (sonora) e eletromagnética (luminosa). McLaren trabalha o espaço e o tempo de maneira polissêmica. Traduz para a imagem a duração de um som em composições abstratas. $O$ som, perturbação de ondas que se sucede no tempo, é representado, conforme os graves e agudos, respectivamente, em imagens mais grossas e mais finas. "Qualquer filme qualificado como científico deve sê-lo por seu assunto e pelo seu espírito" (PAINLEVÉ apud SCHMIDT; DÉRIAZ, 2010, p. 20). Efetivamente, este trabalho de McLaren não "fala" de ciência, mas exibe o sincronismo de forma gráfica, reduz dois conceitos ao máximo da simplicidade, delegando ao estímulo estético a incumbência da construção de sentidos. De certa forma, à exemplo do prof. Münch, seu filme antecipa experimentações realizadas em computação gráfica e em música eletrônica.

A produção de McLaren comporta uma vasta gama de procedimentos e resultados estéticos cuja busca essencial por uma linguagem universal - e humanística é o eixo ou a finalidade. Sua experiência na China e na Índia pela Unesco, para ensinar 
técnicas de animação sem câmera, ${ }^{30}$ contribuiu para uma concepção do uso da imagem com liberdade e acessibilidade. A face educacional de McLaren é muito forte, com trabalhos bem humorados que apelam ao mesmo tempo para o racional e o emocional.

\section{Derive des Continents (1969)}

Em contraste com a produção econômica de McLaren, o cineasta animador holandês Co Hoedeman produziu, também no National Film Board do Canadá, em 1969, A Deriva dos Continentes (Fig. 108), filme que emprega técnicas de animação em stop-motion e maquetes sofisticadas para explicar a formação geológica do planeta, as zonas magnéticas e o movimento das camadas tectônicas.
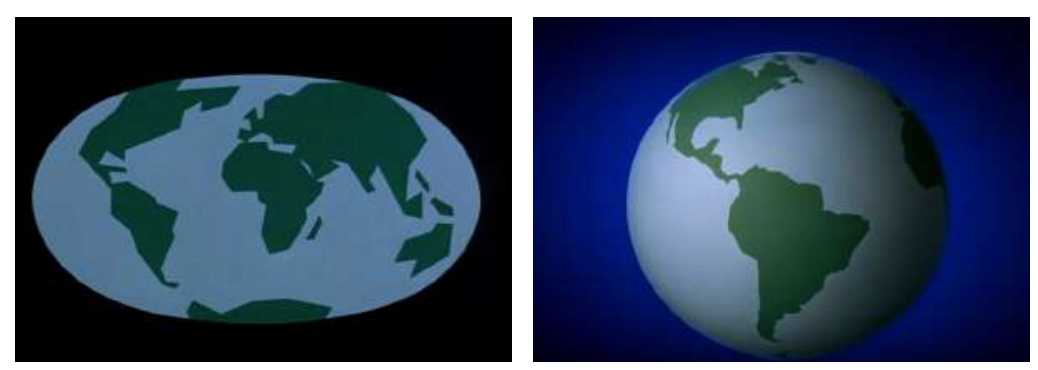

Figura 108: Transposição em corte seco do globo terrestre para o planisfério estilizado em A Deriva dos Continentes, de 1969.

Hoedeman trabalhou com o geofísico J. Tuzo Wilson, da Universidade de Toronto, para demonstrar conceitos complexos mesclando ilustrações estilizadas com a concretude das maquetes. Estas, por sua vez, ora são animadas em quadro a quadro, ora movem-se mecanicamente captadas a 24fps (figs. 109 a 112).

O ritmo sem pressa do filme joga com essa variedade de figurações na relação entre o concreto - as maquetes que representam o planeta e o solo - e o abstrato - as representações gráficas em plano bidimensional. Uma das passagens mais interessantes mostra a abertura do solo em corte transversal, revelando as camadas de lava resfriada ao longo das eras geológicas. A câmera faz um movimento de aproximação e, em seguida, há um corte para a ilustração que estiliza as camadas de forma gráfica, procedimento semelhante ao exibido acima, do globo terrestre ao planisfério: corte da imagem concreta para seu esquema abstrato-gráfico.

\footnotetext{
${ }^{30}$ Cameraless animation, animação desenhada direto na película, sem uso de câmera.
} 

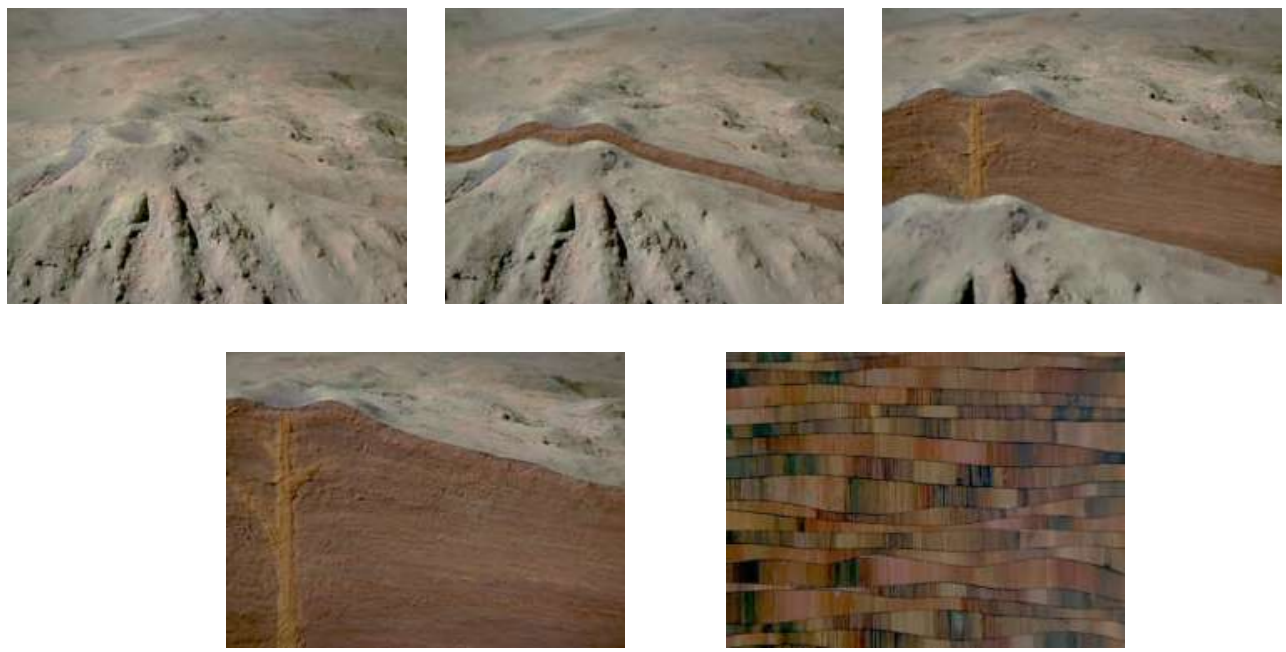

Figuras 109 a 112: Corte transversal no solo revela as camadas de lava resfriada ao longo das eras geológicas em cenas de Dérive des Continentes (1969). As primeiras quatro imagens são uma tomada em live-action da maquete que se movimenta mecanicamente (109 a 111). O esquema gráfico desenhado a partir da observação das camadas mostra as divisões relacionadas às diferentes polaridades magnéticas (112).

Comparações costumam ser um meio eficaz e bastante usado para traduzir uma ideia complexa em um discurso de mais fácil absorção. A comparação da lava vulcânica com o caldo de legumes, para ilustrar o movimento da lava do centro do planeta em direção à superfície, constitui um dos momentos inspirados do filme. Nessa sequência, a montagem inicia com a animação do deslocamento da lava, e, em corte seco, revela-se um caldeirão visto de cima com o caldo fervente.

O filme não conta com trilha sonora musical, restringindo-se a uma narração solene sem permissão para devaneios ou questionamentos, o que poderia despertar curiosidade: em que medida o filme sairia ganhando se houvesse uma certa dose de ousadia e irreverência? Seria também possível injetar energia na narrativa, com trilha que despertasse uma atmosfera de mistério ou maravilhamento? De fato, trata-se de um tema instigante e da maior importância, que se relaciona com fenômenos de várias disciplinas. Entretanto, apesar da excelência na produção e da direção precisa de Hoedeman, o filme, aos nossos olhos, resulta "frio", e em certa medida, datado.

Nos anos 1970, Hoedeman realizou diversos filmes para o público infantil, dessa vez, com música, brincadeira e poesia. Castelo de Areia, de 1978, recebeu o Oscar de melhor curta-metragem de animação. 


\section{Cosmic Zoom (1969)}

Como o nome sugere, Cosmic Zoom, dirigido por Eva Szasz em 1969, consiste em uma viagem pelo cosmos até o ponto mais distante que se pode conceber, e depois, à menor porção de matéria de um ser humano. Inspirado no livro de 1957, Cosmic View, de Kees Boeke, Szasz desenhou uma sequência de ilustrações que, filmadas em fusão uma após a outra, dão a ilusão dos movimentos de zoom-out e de zoom-in.

Grande parte das produções do National Film Board coloca a natureza e o progresso convivendo em harmonia como pano de fundo. Em Cosmic Zoom, esta contextualização apresenta uma sutileza que revela um aspecto não tão positivo: a paisagem onde se vê a natureza e as fábricas exibe também, na cena inicial, chaminés e rejeito industrial lançado nas águas de um rio. A trilha reforça o ambiente de cidade pequena, com som de passarinhos, sino de igreja, enquanto a câmera corrige em direção a um barco que desliza no lago, remado por um menino.

A câmera fixa essa imagem do menino no barco - soam as badaladas finais. A imagem fotográfica torna-se uma ilustração e em seguida se inicia a subida da câmera em zoom-out ao som de uma harpa. Aos poucos, o menino no barco torna-se um ponto ínfimo, some no mapa do Canadá, da América, até que vemos o planeta Terra. A partir deste ponto, outros instrumentos somam-se à harpa, em uma melodia que remete a temas medievais, e continuamos a viagem para longe da Terra, do sistema solar, da Via Láctea (figs. 113 a 118).
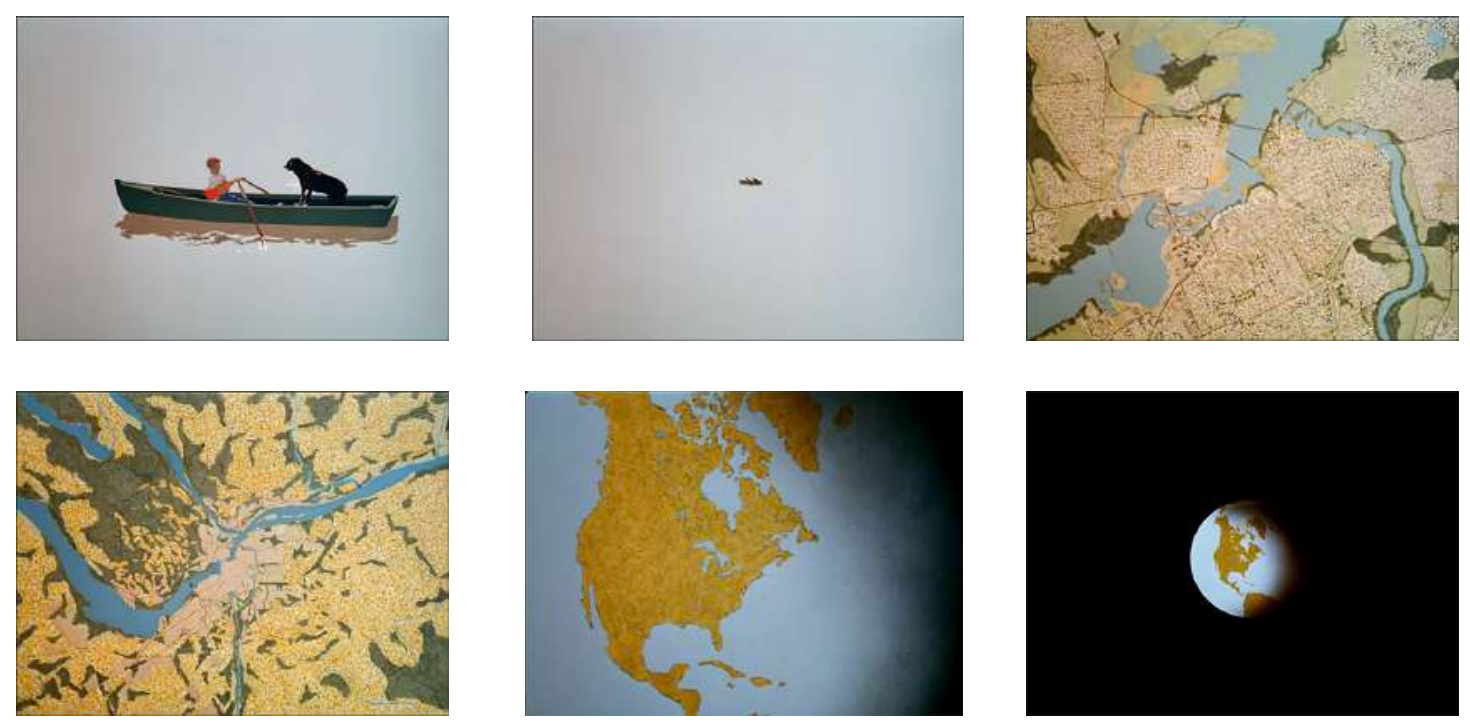

Figuras 113 a 118: Em Cosmic Zoom (1969), a viagem rumo aos confins do universo parte do menino no barco. 



Figuras 119 a 124: Cenas de Cosmic Zoom (1969). O zoom-in penetra nos glóbulos vermelhos e viaja pelas células e moléculas até a menor partícula do ser humano.

Quando a câmera chega ao ponto mais distante, ela para e inicia o movimento de volta, mas agora em alta velocidade e embalada pela mesma música, mas tocada de trás pra frente. Este movimento conduz de volta ao menino no barco, mas não para por aí: ao som da música inicial, a câmera penetra na pele do garoto, no seu sangue, nas organelas celulares, no DNA, nas moléculas, nos átomos e nas partículas subatômicas em movimento de zoom-in (figs. 119 a 124). A partir das moléculas, a representação dos átomos e partículas consiste em ilustrações de esferas. A câmera finaliza o movimento em direção à menor partícula deste ser vivo e começa o movimento de volta à escala humana, ao som da trilha em reverse. Finalmente a câmera atinge novamente o menino no barco, a imagem descongela-se, e o barco volta a navegar. Depreende-se que as viagens aos confins do universo e à menor partícula existem simultaneamente; ou seja, embutida na ideia espacial do deslocamento, há uma ideia temporal, de simultaneidade, de grandezas que existem ao mesmo tempo, enquanto o menino navega.

Eva Szasz não se preocupa em ser cientificamente correta, em mostrar numericamente as escalas, como em uma demonstração de pesquisa. A proposta aproxima-se de uma reflexão poética sobre as imagens que fluem como o fluxo do pensamento contemplativo que se detém sobre um objeto.

No Brasil, a animação também foi suporte para filmes científicos, em regime elucidativo, de modo geral como inserção. Em 1928, Luiz de Barros realizou uma 
sequência de um minuto para o longa-metragem documentário Operação do estômago, a respeito das cirurgias realizadas pelo dr. Benedito Montenegro. Assim como a maior parte da produção brasileira de animação do período silencioso, não há cópia deste filme. Outras produções do INCE (Instituto Nacional do Cinema Educativo) utilizavam inserções de ilustração em meio a cenas captadas ao vivo, com intertítulos seguidos de imagens estáticas, ou com algum pequeno movimento.

Considerando a produção estatal dos filmes educativos - não exatamente científicos -, nos anos 1950, foram produzidos filmes do Serviço Especial de Saúde para campanhas de prevenção de doenças contagiosas, noções de higiene e alimentação saudável. Desenhos animados com forte apelo popularizaram personagens como Sujismundo e Dr. Prevenildo, criados por Rui Pieroti. Ainda nos anos 1950, Igino Bonfioli, um dos pioneiros do cinema mineiro, produziu animações institucionais e publicitárias em colaboração com Fabio Horta, destacando-se Água limpa e Geografia infantil.

\section{$\mathrm{H}_{2} \mathrm{O}(\mathbf{1 9 6 0})$}

Nos anos 1960, o animador Guy Lebrun produziu para o INCE o desenho animado $\mathrm{H}_{2} \mathrm{O}$, em que o narrador explica para o personagem Joãozinho as características físicas da água, suas propriedades, e alerta para a importância da água na vida do planeta (figs. 124 a 126).
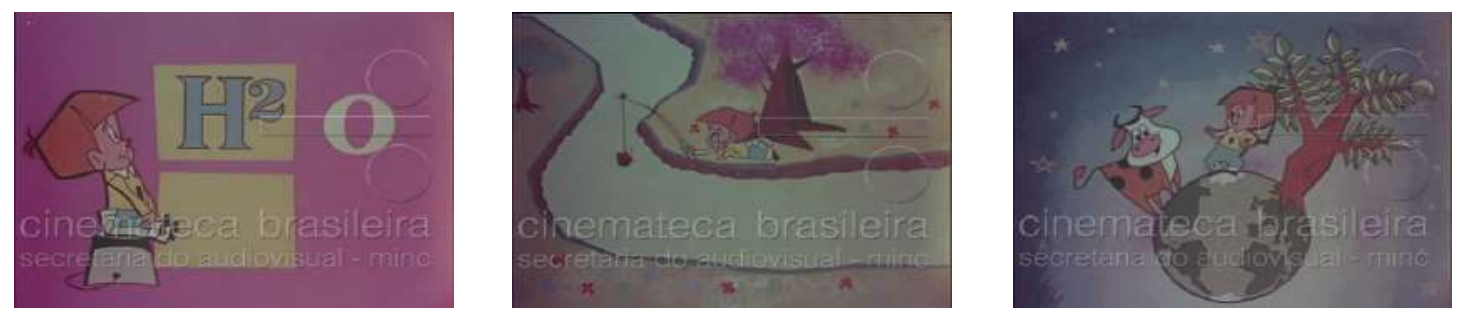

Figuras 124 a 126: Imagens extraídas de $\mathrm{H}_{2} \mathrm{O}$, filme de Guy Lebrun, feito para o INCE.

O filme tem cinco minutos e consiste em uma animação aos moldes das animações publicitárias para TV dos anos 1950-60, ou seja, uma animação "limitada", inspirada na proposta da UPA (United Productions of America), com decupagem eficiente e criatividade nas mudanças de espaço entre um cenário verossímil e um ambiente impossível. Por meio de movimentos de câmera e closes, Joãozinho salta de um ambiente para outro e contracena com os objetos que ilustram as diferentes 
situações em que a água é protagonista. Joãozinho representa as crianças brasileiras a quem a voz over do locutor ensina com uma linguagem terna, próxima do universo da criança em idade escolar.

\section{A medida do tempo (1958)}

A medida do tempo é mais uma produção do INCE, dirigida por Jurandyr Passos Noronha, com vários inserts em animação tradicional realizados por Jorge Bastos. $\mathrm{O}$ filme discute a necessidade imposta à humanidade de medir o tempo, e como esta problemática foi solucionada conforme o desenvolvimento tecnológico, desde os tempos mais remotos até a modernidade, com os mecanismos mais sofisticados de divisão do tempo. Nas cenas em animação, recapitulam-se os movimentos de rotação e de translação da Terra, que geram como consequência o dia, a noite, o ano, as quatro estações. São cenas demonstrativas em que os conceitos são representados didaticamente, inserindo-se gráficos, legendas e pausas.

Os desenhos de rotação do planeta, que transmitem a sensação de tridimensionalidade, são bem realizados, observando-se a época e os recursos com que foram feitos (Fig. 127). Com um tom que transita entre o filosófico e didático, o filme faz a relação entre o tempo e o espaço, mostrando que o movimento foi o primeiro aspecto observado em relação à passagem do tempo, e finaliza postulando que o homem é, ao mesmo tempo, senhor e escravo do tempo.
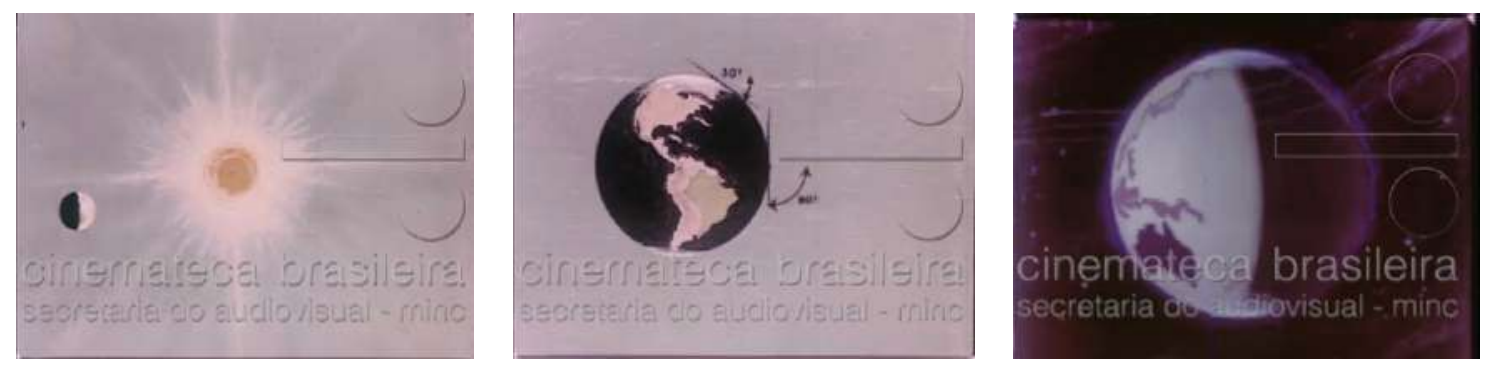

Figura 127: A medida do tempo (1958) usa cenas de animação para demonstrar as consequências do movimento da Terra: "do movimento, surge o tempo, e com ele, a existência e a realidade", declara o narrador em face da inevitável condição humana de subordinação ao tempo. 


\section{Capítulo V}

\section{Tecnologia das imagens científicas e a ponte com a arte - soluções e armadilhas}

Neste capítulo, observaremos como as tecnologias de ponta tornaram-se ferramentas robustas para pesquisas que se apoiam em imagem, instalando complexidade tanto na interpretação objetiva dos dados como na apreciação estética, na criação de sentido, e estreitando a via entre a ciência e a arte. Observaremos trabalhos oriundos de teorias não representáveis fotograficamente e outros cuja combinação de métodos resultou na visualização de fenômenos e universos fantásticos sem conexão física com um referente. A apropriação de imagens científicas pode exceder nossa percepção ordinária e proporcionar prazer estético ao olhar.

Entidade arbitrária como representação, a imagem pode trazer soluções, como tem sido demonstrado ao longo da pesquisa, mas também carrega o fardo de potencial armadilha, sobretudo no campo da imagem computadorizada, criada a partir de situações artificiais e quando não existe o objeto físico referente ao conceito retratado. Portanto, quando se trata de um tema inédito, cujo resultado é desconhecido ou existe apenas na teoria, são necessárias a desconfiança e a repetição dos processos, até que se obtenham resultados mais ou menos estáveis, para que sua interpretação minimize a margem de erro.

No cinema científico, a investigação do movimento sempre foi o motor para o desenvolvimento de dispositivos para captá-lo. À medida que os dispositivos se sofisticavam, criavam-se novas perguntas. O que ainda há para ser visto? Quais evidências podem garantir a existência de coisas ou fenômenos ainda não observados com todo o aparato desenvolvido desde Marey? A união entre a experiência e a dedução é a passagem do empirismo ao conhecimento racional. Todas as imagens obtidas precisam ser transcritas, filtradas dos ruídos, classificadas e analisadas para que tenham utilidade científica. A parte isso, a imagem científica permanece o espetáculo da plasticidade do desconhecido.

As ferramentas de observação/interpretação/medição associadas a novas teorias e conceitos introduzem na problemática científica grandezas não regidas pelas leis físicas tal como as vivemos em escala humana. Os propagadores de ondas de diversos comprimentos do espectro eletromagnético, os raios-X, lasers, gama, ultravioleta, 
infravermelhos permitem a construção de imagens sobre um suporte sensível ao fóton, ultrapassando a fronteira do espectro vísível. Outras ondas, como a sonora, revelam as imagens do eletrocardiograma, ou da ultrassonografia. Há ainda processos como a ressonância magnética, que trabalha com átomos de hidrogênio em um campo magnético. Menor ainda do que o fóton, o elétron dos microscópios eletrônicos revelam estruturas em três dimensões. A maior parte desses dispositivos foi desenvolvida com base em teorias e modelos hipotéticos, abstratos, que só puderam ser comprovados tempos mais tarde. A teoria de Einstein é o exemplo primordial e contemporâneo dessa condição do cientista que trabalha de certa forma às cegas, apenas a partir de cálculos e deduções que dificilmente serão comprováveis, mas que respondem a um número considerável de problemas concretos.

A matemática e a física quântica são, pois, a base para todo a elaboração de métodos e de dispositivos materiais que partem muitas vezes de suposições; são disciplinas-chave para se penetrar em universos inacessíveis, como os buracos negros, a estrutura do DNA etc., permitindo a criação de documentos visuais com informações reproduzíveis em várias escalas. Entretanto, a convicção e o faro permanecem indispensáveis para a produção do ferramental comprobatório de determinada ideia.

Se falamos em criação de imagem científica, é pertinente questionar qual seria a fronteira entre o uso simbólico da imagem e seu valor como testemunho objetivo de um fenômeno. As interpretações e os diferentes pontos de vista, às vezes conflitantes e contraditórios, não isentam o instrumental contemporâneo dos possíveis erros. $\mathrm{Na}$ representação de prótons e nêutrons, é comum utilizar esferas, o que é um erro do ponto de vista conceitual, é um tipo de representação que trai a mecânica quântica, que não permite a localização precisa das partículas. Uma representação mais apropriada seria uma névoa vibrante. No caso dos elétrons, ainda mais difíceis de capturar, o que se obtém é a imagem com uma região mais luminosa, onde há maior probabilidade da ocorrência de sua passagem. Para a representação de partículas subatômicas, é possível apenas registrar um evento ultraefêmero que ocorre dentro do acelerador de partículas. Provoca-se a quebra do átomo com a liberação de partículas que nunca serão vistas, mas um detector capta os traços luminosos originados pela explosão. A imagem resultante deste processo, submetida a medições e equacionada, permite descrever a história do choque, como foi o acidente, quanta energia foi liberada etc. (figs. 128 e 129). Ou seja, essa visualização jamais será direta: ela é uma proposição dos matemáticos e de analistas, e é o cientista quem vai avaliar se essas imagens são prováveis, se funcionam 
como modelo de codificação, dentro do quadro teórico por ele projetado. Não se trata apenas da representação, mas da produção de sentido.
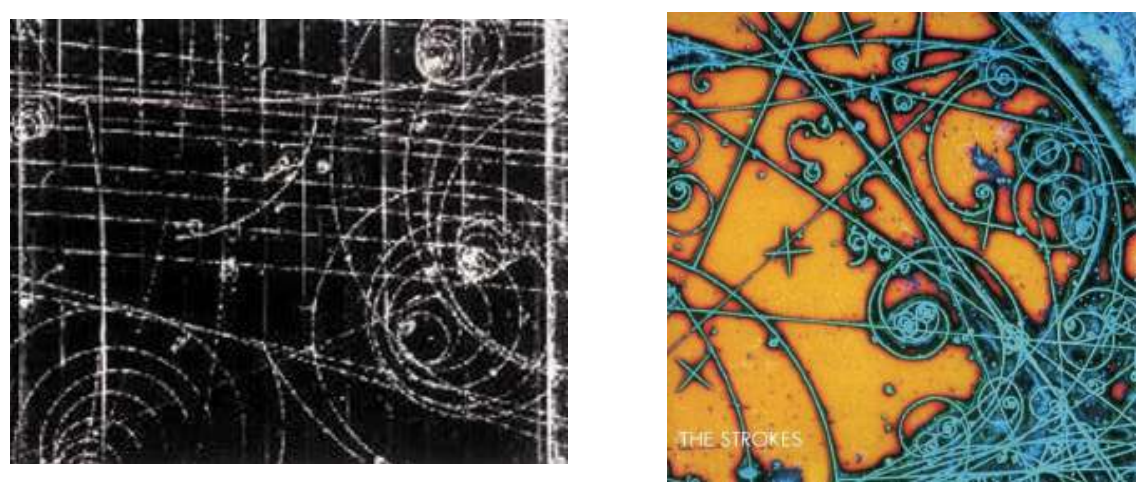

Figuras 128 e 129: À esquerda, fotografia da câmara de bolhas (1964) do prof. Donald Glaser, Nobel de física em 1960, usada na contra-capa do album This is it (2001), da banda The Strokes. Trata-se de uma imagem que depende de interpretação a partir de um conhecimento prévio, assim como a imagem de um ecocardiograma ou de uma ultrassonografia.

Há portanto uma ruptura epistemológica no processo de virtualização da investigação científica, cuja observação do real é um dos pilares. Não existe mais observação do real, mas uma mediação da realidade hipotética por dispositivos, ou ainda, uma simulação a partir de informações periféricas ao fenômeno. Semelhante ao que ocorre nas câmeras de névoa ou nos aceleradores de partícula, cria-se uma situação que fornecerá dados para leitura e interpretação. Essas imagens também carregam sentido, credibilidade e engendram novas tecnologias, como é o caso do microscópio eletrônico.

O desenvolvimento do microscópio eletrônico de varredura (Fig. 131) deve-se ao estudo do comportamento da luz, do eletromagnetismo e das partículas - elétrons.
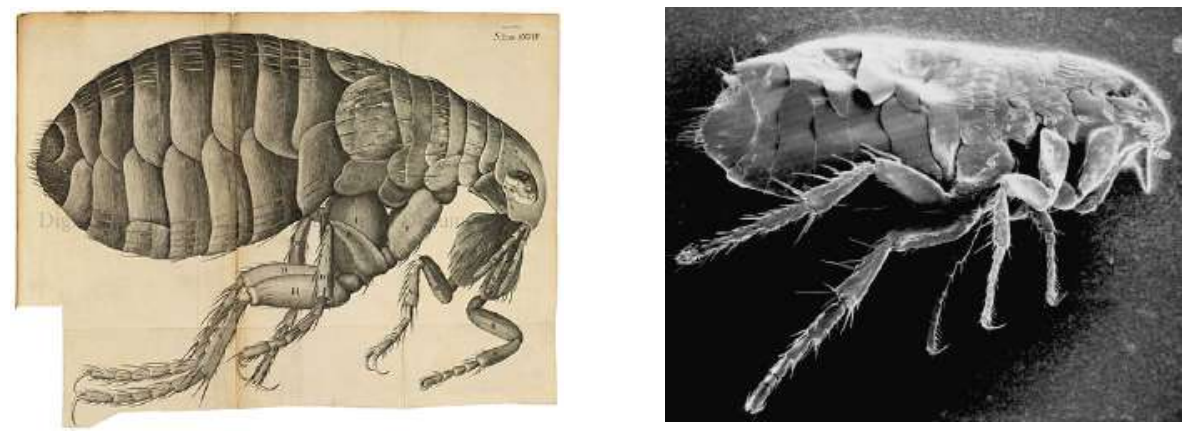

Figuras 130 e 131: À esquerda, gravura da pulga a partir do desenho Robert Hooke, que usou um microscópio ótico para estudar seres minúsculos no livro Micrographia (1665). À direita (131), a imagem de um microscópio eletrônico que comprova, mais de 300 anos mais tarde, a anatomia desenhada/proposta por Hooke. As difrações modalisadas do feixe de elétrons, 
permitem a reconstrução do objeto em três dimensões.

A física quântica e a cosmologia também apresentam fenômenos que escapam à compreensão usual, ao senso comum - o tempo de vida humano, nossa escala de distâncias e relações de causa-consequência são obstáculos a uma imensa gama de conhecimentos deste terreno. Algumas de nossas noções não são representáveis, por exemplo, a probabilidade da presença de um elétron. Daí a necessidade de criar métodos de investigação dissociados do modo da física clássica, de tudo com o qual temos familiaridade. Frente a esse tipo de fenômeno, a representação visual passa também por medição, simulação e interpretação - esta imagem será a criação de um símbolo sem um objeto referente.

Outra situação em que a imagem promove suporte para o conhecimento é na tradução de um determinado sistema matemático para a interpretação dos resultados. Quando um sistema com muitas variáveis resulta uma infininidade de dados, os pesquisadores podem recorrer à imagem para uma "leitura" mais rápida. Antes da computação gráfica, os matemáticos trabalhavam praticamente às cegas. A ideia de transcrever esses dados para imagens é a de apelar para o sentido da visão para encontrar simetrias, periodicidades, padões - interpretação. Quando se trabalha com o desconhecido, é mais difícil saber se há algum erro. Um código de 50 mil linhas de comando pode conter erro em alguma linha, e esse erro pode se replicar e ampliar as distorções, as quais podem ser detectadas com o auxílio de imagem.

A criação de imagens fractais é um exemplo do uso da informática para a transcrição de dados numéricos. O matemático Benoît Mandelbrot foi pioneiro ao utilizar a computação para visualizar sistemas numéricos. Ele partiu dos estudos em dinâmica analítica complexa propostos no início do século XX pelos matemáticos Gaston Julia e Pierre Fatou, que estudaram processos que obedeciam a funções e algoritmos recursivos. Em 1905, sem um computador, Fatou fez gráficos à mão para comprovar que, uma vez que um ponto atinge uma distância da origem maior que 2 , sua órbita explode para o infinito.

Na década de 1970, Mandelbrot utilizou um computador para executar os cálculos da função de Fatou e Julia, e conseguiu imprimir uma imagem resultante. $\mathrm{O}$ termo fractal refere-se a fenômenos da matemática que exibem um comportamento caótico ou surpreendente. As imagens são como frações de uma imagem maior, podendo ser ampliadas infinitamente, repetindo sempre o mesmo padrão. Em 1975, Mandelbrot lançou o livro Les objets fractals: forme, hasard et dimension, em que 
estudou funções aleatóreas e interações complexas entre funções. Inicialmente, a única pretensão era responder a questões da figuração de superfícies e de sua rugosidade, sem nenhuma preocupação estética. Mas seu sistema demonstrou que poderia haver uma outra geometria da natureza que não a euclidiana.

\begin{abstract}
Não se trata de arte por amor à ciência, aquela dos desenhos ou fotografias de flores, árvores ou turbilhões. [...] aqueles que exaltam a beleza da natureza comparam-na [a matemática] frequentemente ao caráter seco e mecânico da geometria e da teoria. E, bem, as imagens fractais nos provam que existe também uma arte de amor à teoria científica e à matemática. Na minha obra, a teoria científica e a matemática possuem um aspecto gráfico forte e plasticamente belo. A arte fractal é ao mesmo tempo utilitária e pura. Enquanto a arte utilitária tem o direito de usar todos os artifícios para decorar, educar, divertir ou convencer, a arte científica deve apenas imitar os dados da natureza com o mínimo de intervenção. (MANDELBROT, 1984, p. 2)
\end{abstract}

As imagens fractais dão uma medida precisa da importância do desenvolvimento da matemática graças à computação, gerando imagens de rara complexidade, beleza e inimagináveis sem seu auxílio (figs. 132 e 133). Mandelbrot, pôde, pela primeira vez na história, descrever a natureza a partir da linguagem matemática, criando imagens fracionadas que repetiam a forma do todo infinitamente, em gráficos hipnóticos. Além da utilidade de seu estudo na natureza - como formação de cristais, a forma das montanhas, as núvens - a teoria dos fractais estendeu-se para a física e para a economia, com a junção das teorias da probabilidade e da estatística.
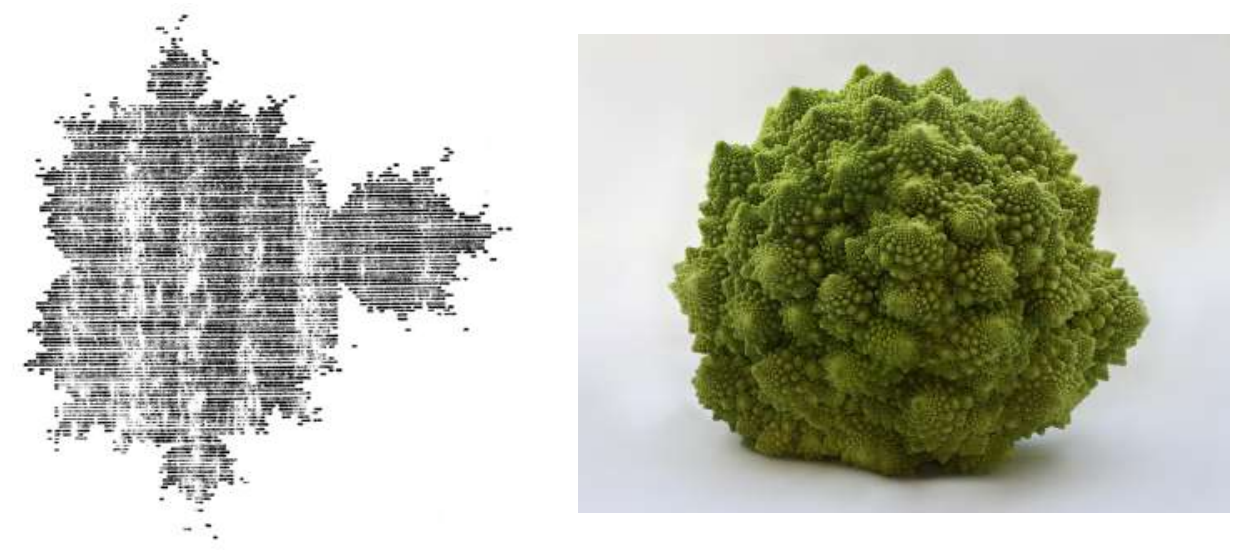

Figuras 132 e 133: À esquerda, impressão a partir de uma equação fractal, feita por Benoit Mandelbrot (1980) na Universidade Harvard, que começou a usar os primeiros programas de computador para criar imagens da estrutura matemática que passou a se chamar esquema Mandelbrot (Mandelbrot set) (HAYES, 2013). À direita, um exemplo de fractal na natureza, o brócolis romanesco (ROMANESCO BRASSICA, s.d.).

A previsão climática, é outro exemplo da aplicação dos modelos matemáticos 
combinados com estatística e probabilidade em meio computacional para a geração de imagens. A animação de massas de ar atmosféricas mostra as sucessão de imagens resultantes das mudanças de muitas variáveis durante um período de tempo - a evolução de um sistema no tempo. É uma demonstração digital que pode ser tomada como verdade, mas ela é efetivamente a resultante de várias probabilidades. É a abstração de uma ordem preestabelecida em uma tentativa de organizar o caótico movimento da natureza.

Se a matemática serve para descrever nosso universo, serve também para universos imaginários.

A animação digital surge como um imenso repertório de possibilidades, geradas do cruzamento de todas as formas de representação criadas até o momento. Em minha dissertação de mestrado, defendida em 2014, discorro a respeito do início da computação gráfica, do uso militar e dos precursores da computação analógica no campo do cinema de animação (MARQUES, 2014). Desde os anos 1970, as imagens de computação gráfica vêm ampliando seu escopo de aplicação, sendo o computador considerado o último limite para o domínio do espaço-tempo, sem as restrições do mundo físico (COLONNA apud SCHMIDT; DÉRIAZ, 2010, p. 209). No cinema científico, a computação e os recursos digitais são aparentados do hibridismo por excelência, porque se combinam com outras ferramentas, como microscópios, telescópios e câmaras de névoa, gerando dispositivos capazes de testar hipóteses, mudar variáveis e trabalhar com o imponderável. Seu imenso valor, sobretudo na física, na matemática e na biomedicina, é materializar eventos com rigor conceitual, apresentando vistas jamais possíveis pelas câmeras tradicionais ou digitais. Como discutimos ao longo desta pesquisa, mesmo nas ciências exatas trabalha-se com o imponderável e com o incerto.

As imagens em 3D são o desenvolvimento natural da geometria euclidiana, em que se representam os objetos a partir dos três eixos, $\mathrm{X}, \mathrm{Y}$ e Z, primeiro com a criação de formas simples em direção à complexidade das formas mais orgânicas. A evolução da computação gráfica possibilitou tal criação. Mas para que ela aconteça, é necessário determinar um ponto de vista, identificar qual o código de representação, as cores, as texturas, a escala temporal e o grau de estilização da imagem. As imagens e animações hiper-realistas, criadas com softwares 3D, exemplificam a materialização de ideias, teorias ou conceitos, e surge como a revelação preciosista de uma realidade fantástica com detalhes inatingíveis à percepção. $\mathrm{O}$ termo hiper-realista nas artes refere-se à 
tendência da arte contemporânea, no final dos anos 1960, de retomada do realismo figurativo - contrariando a arte abstrata e minimalista -, com obras de tamanho às vezes monumental retratando minuciosamente uma fisionomia, como se o tempo fizesse uma pausa para nos aproximarmos e observarmos cada ponto de uma imagem. Podem ser fotografias, esculturas ou ambientes imersivos em que a figuração tridimensional rende à imagem um aspecto mais real do que a própria realidade.

A produtora Hybrid Medical Animation apresenta um portfólio centrado em ilustrações e animações voltadas para medicina em computação gráfica de extrema acuidade técnica e artística. Além de contar com artistas gráficos, escultores digitais e animadores, a produtora conta com um médico pesquisador para dar suporte conceitual e ser a interface entre os artistas e os clientes. Além dos vídeos, a Hybrid realiza trabalhos em relidade virtual e exposições com ambientes imersivos com estereoscopia e experiências de atualização de imagem em tempo real. O virtuosismo no trabalho com as imagens faz o espectador sentir-se dentro da corrente sanguinea ou dentro do intestino, com a representação háptica dos tecidos e organelas (Fig. 134), sempre em movimento, sugerindo vida.

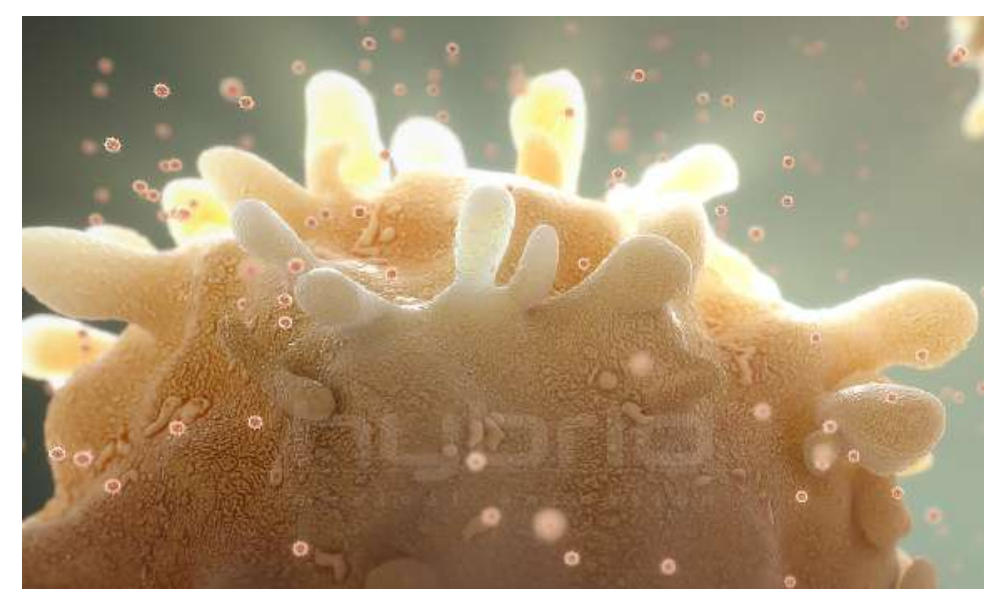

Figura 134: Partículas do HIV brotam da célula hospedeira infectada (linfócito T) (INFECTED T LYMPHOCYTE, s.d.). A imagem com forte apelo ao sentido do tato apresenta uma contraluz, uma textura e um padrão de movimentos que não necessariamente correspondem ao que acontece na vida real. Como criações artísticas, são filmes que representam modelos que funcionam como estímulo à compreensão do fenômeno muito além do que uma desccrição textual poderia promover.

O trabalho fotográfico das imagens simula uma profundidade de campo estreita com uso de lente macro, promovendo espacialidade tridimensional em que o observador, ao focalizar um determinado ponto - determinado pelo artista -, deixa o 
restante da imagem em desfoque. Esse procedimento de escolha do ponto focal traz em si o sentido de parte pelo todo, ou seja, o ponto que se mira repete-se para o além foco organicamente. A perspectiva artística esforça-se em oferecer uma imagem que, para o espectador, seja verossímel. Consciente da impossibilidade de estar naquele ambiente, o espectador flutua entre a crença na materialidade do que vê, e uma certa desconfiança, posto que os exageros em alguns aspectos da fotografia, das movimentações de câmera, mesmo da trilha sonora podem levar ao questionamento: o que garante que isso é verdade? Volta-se assim para a questão elementar da necessidade de comprometimento ético de quem realiza as imagens.

Trazendo à lembrança as grandezas opostas de Powers of Ten e de Cosmic Zoom, partimos do universo microscópico no interior do corpo humano rumo às mais distantes galáxias. Os recursos da computação gráfica, cada vez mais sofisticados, têm ajudado na representação de dimensões gigantescas e diminutas, ambas difíceis de se conceber em imagens. Entretanto, o astrônomo e especialista em efeitos visuais Doug Trumbull encontrou nos recursos da própria câmera de filmar tudo de que precisava para compor algumas das cenas mais notáveis da história do cinema: o espaço cósmico de 2001 - uma odisseia no espaço. Durante mais de quarenta anos pesquisando efeitos especiais para vários filmes de longa-metragem norte-americanos (Contatos imediatos de $3^{\circ}$ grau, Blade Runner, De volta para o futuro ii, entre outros), Trumbull uniu seu conhecimento em física conceitual e prática para desenvolver efeitos especiais mais orgânicos e convincentes do que a computação gráfica usando fluidos e fumaça em tanques de vidro (figs. 135 a 137). Com iluminação adequada e trabalhando a mil frames por segundo, seu trabalho consiste em criar uma circunstância em que o simulacro do fenômeno desejado possa acontecer em menor escala. Não se trata apenas de imaginar o aspecto visual da cena, mas de compreender o funcionamento da percepção visual para produzi-la com verossimilhança. É preciso equacionar a densidade dos fluidos, a velocidade dos ventiladores ou dos motores de turbilhão, tudo isso com aspectos da percepção visual que vai identificar na organicidade da cena a sua verossimilhança, em um processo que busca uma aproximação imersiva do espectador.

O estudo visual da dinâmica de fluidos e a compreensão matemática de seus atributos vêm contribuindo para várias áreas da ciência e das artes desde os registros de Marey, que exerceram influência sobre a arte de vanguarda no início do século XX. Trumbull apropriou-se desse conhecimento para criar efeitos e simular universos na indústria do entretenimento. 

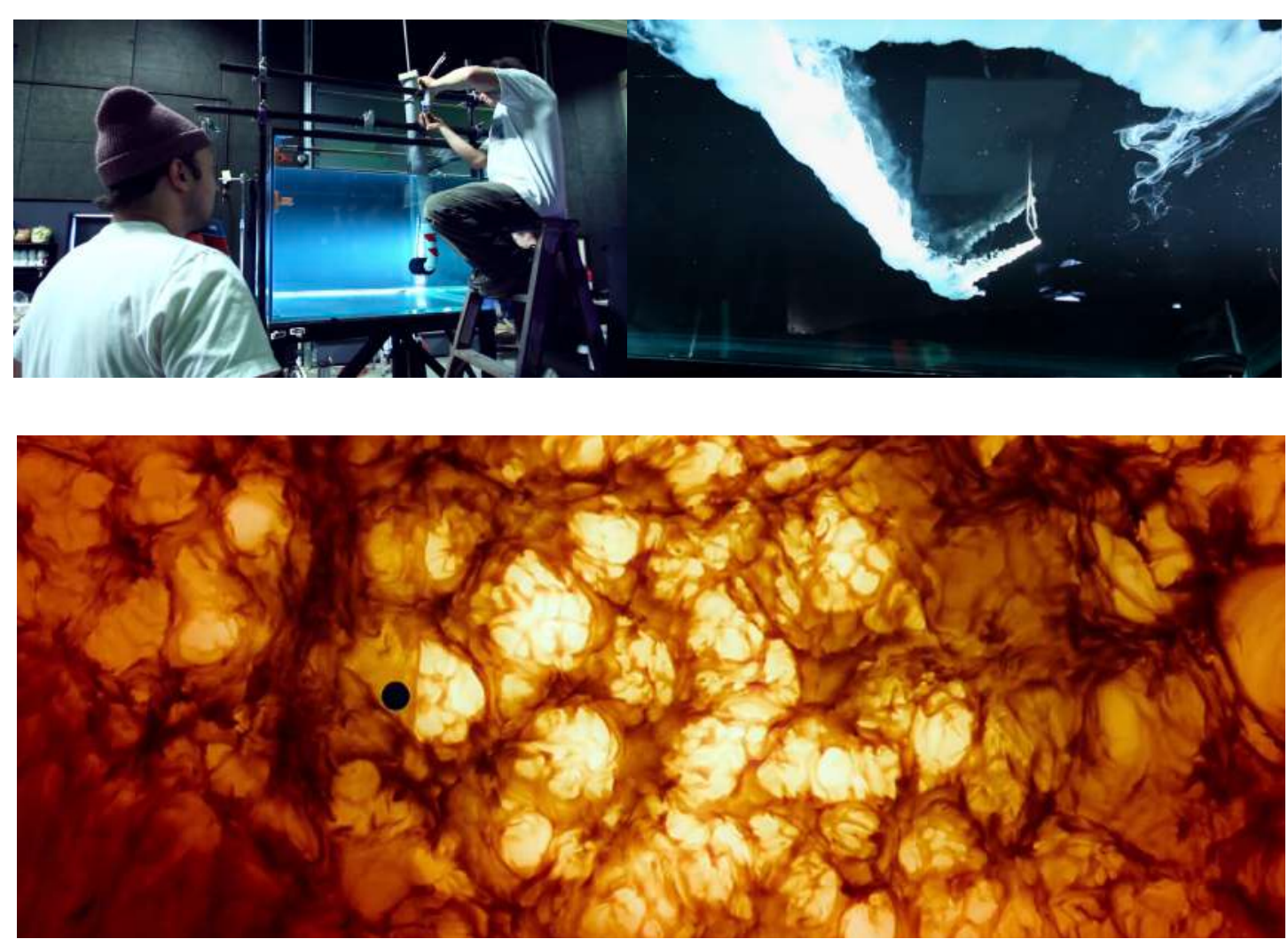

Figuras 135 a 137: No estúdio de efeitos para cinema de Doug Trumbull imagens de nebulosas, de buracos negros, de explosões no espaço são criadas com materiais concretos para garantir o aspecto orgânico e natural. Abaixo (137), imagem do nascimento do universo no filme $A$ árvore da vida (2011), de Terence Malick. "Trabalhamos com químicos, tinta, corantes fluorescentes, líquidos de diferentes viscosidades, fumaça, discos giratórios, gás carbônico, contra-luz e alta velocidade para experimentar os efeitos mais impressionantes" (VIDEO: TREE OF LIFE VISUALIZES THE COSMOS WITHOUT CGI, 2011).

Já o físico e engenheiro mecânico Milton Van Dyke permaneceu na academia, mas sua obra An Album of Fluid Motion (1982) repercutiu através das décadas como referência na mecânica dos fluidos e também nas artes. Impressionado com a natureza plástica dos experimentos em ótica publicados no Atlas de phénomenes optiques (1962), Van Dyke reuniu fotografias de físicos e de colegas cientistas de todo o mundo, cujos experimentos com fluidos (gases e líquidos) resultaram em fotografias tão belas quanto úteis para o estudo da disciplina (figs. 138 a 140). Organizado tal como um álbum de fotografias, o album de Van Dyke é recheado de imagens acompanhadas das legendas com as especificações técnicas. Fora essas legendas, o único texto é a introdução, de apenas uma página, em que Van Dyke explica sua aproximação com a mecânica de fluidos, destaca o caráter pessoal e de certa forma casual de sua curadoria e agradece aos colaboradores. A ausência de palavras de Van Dyke frente à uma coleção de 
imagens fantásticas compara-se à expressão quase lacônica de Marey ao apresentar as séries de fotografias de fumaça, sobre as quais ele tinha pouco a dizer, dada a capacidade que as imagens têm de "narrar" o fenômeno. Van Dyke reuniu fotos a partir de 1888, dividindo-as em temas como "vórtices", "instabilidade", "turbulência" e "fluxo supersônico". Para ele, sinteticamente, a ótica e o comportamento dos fluidos são disciplinas pródigas em oferecer belas imagens.


Figura 138 a 140: À esquerda (138), Instabilidade forçada de um jato redondo. Registro cronofotográfico de ondas sonoras periódicas introduzidas através de um alto-falante próximo ao jato de fumaça. Fotografia de R. Wille e A. Michalke (VAN DYKE, 1984, p. 71). À direita (139), ondas em padrão tridimensional regular lembram as ondas em mar aberto. Fotografia de Ming-Yang Su (VAN DYKE, 1984, p. 114). Abaixo (140), um jato de nitrogênio é lançado em um tanque preenchido com helio-argônio sob pressão de quatro atmosferas (VAN DYKE, 1984, p. 102). Essas imagens de puro encanto formal, realizadas em universidades, com equipes de engenharia produzindo as condições necessárias, remetem aos estudos de Etiene-Jules Marey, atualizam-nos.

Conscientes de que as fotografias são um prelúdio para o estudo matemático do fenômeno, a American Physical Society lançou um concurso anual de fotografias com fluidos, cujos critérios de avaliação são: "beleza artística, inovação da visualização e a contribuição para a melhor compreensão dos fenômenos dos fluidos" (DASTON; GALISON, 2010, p. 403). O estudo foto e cinematográfico de fluidos possibilitou o desenvolvimento de simuladores computacionais e algoritmos que permitem analisar fenômenos atmosféricos e maritmos, e também são empregados em inúmeros segmentos da indústria. 
No campo microscopia eletrônica, a necessidade de ampliar a capacidade de armazenamento de dados levou a IBM a pesquisar as propriedades magnéticas dos átomos em superfícies metálicas. Para tanto, foi preciso desenvolver um íma microscópico e trabalhar a uma temperatura de $-260^{\circ} \mathrm{C}$ para que os átomos ficassem estáveis. Ampliado 1 milhão de vezes (razão semelhante a uma laranja em relação ao planeta terra), The Boy and His Atom (2013) vai até o limite de nossa capacidade de observação de estruturas mínimas conhecido até o momento desta pesquisa. O filme de um minuto em stop-motion é uma experimentação em que se movimenta cada átomo individualmente com o auxílio de uma agulha imantada que o atrai e o desloca - sem tocá-lo - para compor os desenhos que formam as cenas (Fig. 141). Com um aspecto pontilhado e metálico, os personagens que dão nome ao filme são desenhos simples em que os átomos de carbono movimentam-se em um plano nos eixos $\mathrm{X}$ e Y para contar a história de um menino que se apaixona por um átomo, brinca com ele. Ao final, os movimentos formam o logotipo da IBM. (A empresa patrocina pesquisa em imagens e filmes há várias décadas, assim como a AT\&T, que também possui um enorme arquivo em filmes que tratam do comportamento de ondas, da composição de transístores, enfim de tudo que envolve telecomunicações.) A trilha sonora é uma melodia sintética que evoca o som metálico das caixinhas de música, parecido com o emito por um xilofone diminuto. Boy and His atoms inscreve-se em um tipo de produção realizada por cientistas com um objetivo menos artístico do que comprobatório, e resulta em uma obra que desperta mais a curiosidade tecnológica do que o sentido estético.

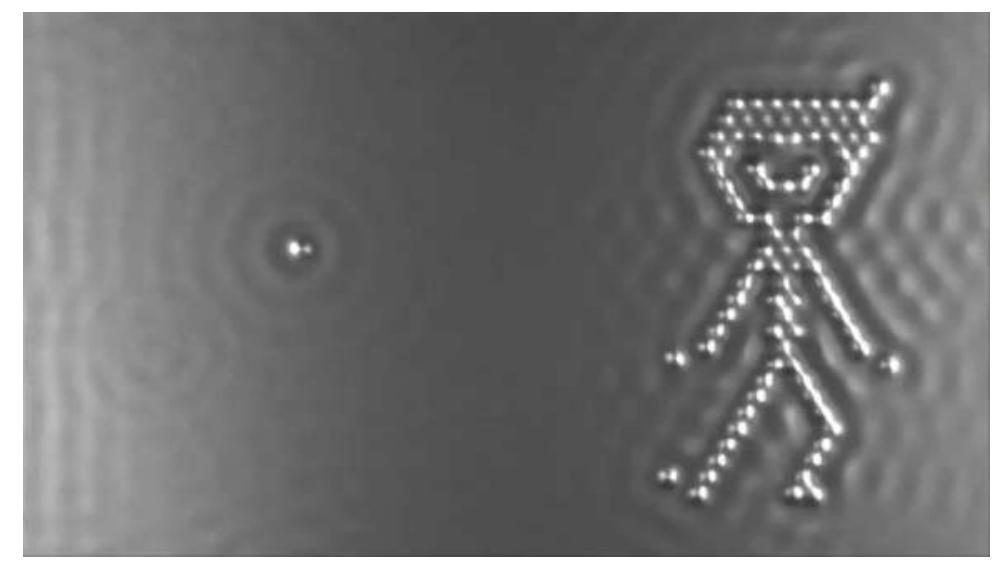

Figura 141: Em A Boy and His Atom (2013), cada esfera corresponde a um átomo de carbono, e as ondulações ao redor são os elétrons da superfície metálica atraídos pela presença do átomo. A experiência nanoscópica representa mais um marco de tecnologia de ponta na história da hegemonia da IBM. 
O exemplo que daremos a seguir é possivelmente uma das aplicações mais experimentais na concepção de um cinema científico genuíno: sem haver previsibilidade alguma em relação aos resultados, uma equipe multidisciplinar, incluindo matemáticos, neurocientistas e artistas gráficos, produziu um aplicativo que traduz para imagens em movimento a transmissão dos impulsos neurológicos e o "estado de espírito" do voluntário, que veste um capacete neural conectado ao crânio, em tempo real. Com uso de inteligência artificial na criação dos algoritmos que geram as imagens, essa experiência extrapola os limites do campo da nossa investigação, centrada no cinema em película, mas compartilha com ela questões estruturantes: (1) equipe multidisciplinar, (2) interpretação de um fenômeno concreto por meio de um dispositivo científico-tecnológico para geração de imagem, (3) criação artística e (4) geração de conhecimento.



Figura 142: Mind Fluctuations é uma animação obtida por meio do aplicativo Numeric Variations, com a ligação de eletrodos ao cérebro de um indivíduo a um sistema computacional. Implementação de Márcia Fraga e Maida Withers, do Instituto de Matemática e Arte de São Paulo.

Mind Fluctuations (2015) é um curta-metragem de animação computacional desenvolvido a partir do aplicativo Numeric Variations que interpreta sinais neurológicos em forma de figuras geométricas coloridas, cenários e música digital. Os estados de espírito do voluntário são captados por eletrodos e as informações processadas revelam, em tempo real, essas oscilações neurológicas. O trabalho artístico de Tânia Fraga e Maida Withers, em paralelo com os programadores e matemáticos, resulta em animações tridimensionais, um voo em um horizonte colorido e sem lógica. A trilha sonora, reminiscente de música concreta, também é criada a partir dos inputs das ondas cerebrais, resultando em uma trilha sintética sem uma linha melódica e bem 
adequada para acompanhar o insólito ambiente criado. É um trabalho que flerta com o universo onírico, levando o espectador à interação com universos mentais. As animações nunca se repetem, apesar de ocorrerem em ambientes semelhantes, e mostram sempre movimentos relacionados à vida, embora sejam a expressão de um universo matemático. Como trabalho experimental, é a expressão do mundo virtuosista da matemática, frio e autêntico, um arcabouço de conhecimento construído em camadas e imbricamentos.

Com estas amostras de trabalhos que unem tecnologias à criação artística, tendo sempre a produção de conhecimento no foco de atenção, procuramos explorar um panorama representativo de muitas tendências nas mais variadas disciplinas, reconhecendo que este campo é um domínio inesgotável. 


\section{Considerações finais}

O termo "considerações" no lugar de "conclusão" pareceu mais pertinente e em consonância com o tom desta pesquisa, que lida em certa medida com o que há de implícito e impreciso no campo da ciência. Além disso, o termo é mais aberto a discussões e desdobramentos. A escolha por um tema apaixonante não me eximiu de confrontá-lo, de procurar pontos cegos e de criticá-lo, buscando contudo não emitir juízo de valor em relação às práticas, já que compreendê-las é saber que atendem a um questionamento que corresponde a uma necessidade instalada em uma determinada visão de mundo.

Pesquisar o modo como a ciência olha o mundo mediada pelo cinema permitiu entrar em contato com um panorama amplo e heterogêneo de imagens de diferentes épocas e contextos culturais. Desse repertório, foi possível extrair algumas noções/considerações em meio à complexidade das disciplinas envolvidas, seguindo as seguintes premissas: (1) objetivo da ciência é conhecer a realidade e ser capaz de fazer previsões; (2) todo processo científico é interpretativo; (3) o cinema científico é uma criação sujeita a metodologias, passível de contaminações e de falhas; e (4) as imagens científicas são impregnadas por uma plasticidade enigmática.

Da década de 1970 aos dias de hoje, o diálogo entre pesquisa científica e linguagem audiovisual vem ganhando novos contornos, mais fluidos, englobando toda ferramenta de visualização de dados, de toda natureza. As imagens em movimento deixam de pertencer exclusivamente ao mundo da tela e do entretenimento, as discussões ampliam-se e denunciam de modo contundente a onipresença das imagens audiovisuais em quase todos os aspectos da vida moderna, transformando nosso modo de estar no mundo.

Nossa ferramenta primordial de apreensão do mundo, os olhos, leva ao cérebro as informações que se transformam em imagens. Nosso córtex compara, sobrepõe e produz uma imagem que faz sentido (TERNAY, 2010, p. 102). Como construção mental, pode-se dizer que a imagem é a representação do real. Disso decorre o fato de que nós, humanos, não teremos acesso visual do real, mas à produção de sua representação (problema bastante discutido nas artes, na filosofia e na ciência). A observação, um dos pilares do método científico, ganhou gradativamente reforços para aumentar seu alcance, entre eles, os que chamamos reforços mentais - a matemática, os 
modelos teóricos - e os reforços materiais - telescópios, scanners, radares. O cérebro e os olhos, em consórcio com os reforços mentais e materiais, montam as imagens que podemos chamar de metafóricas - representantes da realidade. Desde o esfimógrafo de Marey, a tradução de fenômenos invisíveis ao olho nu para a imagem gráfica constituiu a materialização de uma hipótese que se estruturou primeiro em forma de conceito.

A observação é, portanto, um processo ativo, gestáltico e holístico - imediato e intuitivo - de apreensão do mundo. Na ciência moderna o esforço intelectual empreendido gira em torno da formulação abstrata, partindo-se da experiência visível concreta, empírica (fenômenos observáveis). No cinema científico, as imagens existem em função da compreensão das formulações teóricas, sendo que o elemento estético, em alguma instância, revela/traduz o desconhecido, o objeto pesquisado. As figuras de Muybridge, Marey e Painlevé, entre outros, são o exemplo mais acabado dessa persona científica incansável e inesgotável. Estudar o emprego do cinema nas ciências é entender a relação entre a ciência e a modernidade, entendendo que a ciência - assim como vida - é inerentemente cinemática.

O cinema é uma das ferramentas artísticas que permite agir sobre o tempo de forma mensurável, não apenas no tempo psicológico e subjetivo, como a música, a dança e o teatro o fazem desde sempre (SCHMIDT; DÉRIAZ, 2010, p. 23). A adaptação do cinema à investigação científica é equivalente a qualquer outra tecnologia, do microscópio ao computador. O uso artístico do cinema tem muito de científico e é difícil dizer se o que fascina é o valor artístico ou o científico.

Por pertencer ao domínio do documental e do inefável ao mesmo tempo, a imagem é uma fonte de conhecimento e emoção, ligada tanto à objetividade quanto à subjetividade. No cinema, o cruzamento entre a arte e a ciência é uma questão central, já que se trata de uma arte técnica e multidisciplinar. O cinema é conveniente não apenas como dispositivo adaptável de pesquisa científica, que permite isolar e quantificar componentes de um fenômeno, mas como veículo de compartilhamento de um determinado modo de pensar. É ao mesmo tempo solução e criação de problemas, já que a representação, o aspecto subjetivo incontornável, pode gerar ambiguidade. $\mathrm{O}$ arbitrário é muitas vezes fonte de anomalias, principalmente quando se trata de sínteses, simplificações e resumos, mas é também uma brecha para o poético, quando a beleza do fenômeno e o modo como é retratado sugerem sem palavras e enlevam o espectador.

O exercício do cinema científico é a observação permanente de um certo rigor na construção do discurso em imagens. Quer dizer que, do lugar que ocupa, o cientista- 
cineasta tem a seu favor a presunção da verdade; o que ele diz tem credibilidade reconhecida, mas ao mesmo tempo, enquanto cineasta, sua postura criativa é requisitada, sua contribuição não se restringe ao fenômeno que ele está a mostrar, mas ao modo como interpela o espectador para o que há de único nele. Contudo, o estético não deve se sobressair ao científico, e esse desequilíbrio é algo a evitar. "Como todo meio de investigação, o cinema porta em si o potencial de falso-testemunho" (PAINLEVÉ, 1956, p.10). A especificidade, portanto, da estética cinematográfica voltada ao conhecimento almeja uma clareza, de maneira que o cientista ofereça ao espectador a visão do que é relevante no fenômeno. Esta é uma característica central no cinema científico.

Daí a importância do cinema testemunho que documenta, explica, prova. Daí a mágica de alguns processos observáveis. O prazer de não saber o que está por vir, da surpresa compartilhada, é reforçado pela consciência de poder assistir a algo possivelmente real dentro de um sistema de valores, seja qual for o modo como a imagem foi obtida. De fato, o que nos é revelado pode significar um ângulo ou um recorte da realidade baseado na evidência que merece atenção.

O cinema científico pode ser entendido como um subgênero do documentário e, de um modo geral, compreende os filmes de pesquisa (research films - coleta de dados) e os filmes com temática científica para difusão de conhecimento. É uma prática que combina dois tipos de percepção, inerentes à cinematografia e às ciências: a estética e a cognitiva. A apropriação de um conhecimento implica a atividade do sujeito além da memorização passiva. É preciso que o espectador se esforce para criar relações. Não obstante, a chave para nos aproximar dos filmes científicos e deles extrair algo que nos afete, que transforme o nosso estado inicial, é a fruição, sem a qual não existe a identificação, a entrega. Um conteúdo que se faça transmitir com fruição pode destilar às vezes durante anos e resultar em conhecimento.

Tanto no cinema científico como nos experimentos científicos, os protocolos a serem observados são os mesmos, integrando inevitavelmente objetividade e subjetividade. A demonstração e a prova por meio de filmes são submetidas às mesmas regras de validação como qualquer outro método investigativo. Assim, o cientistacineasta esforça-se para obter, entre outros, o melhor ângulo de observação, a melhor relação figura/fundo, o contraste ideal, além de repetir numerosas vezes a experiência que se propões a retratar, até que obtenha o resultado visualmente convincente.

A especificidade da montagem do filme é o gatilho silencioso das operações 
mentais envolvidas na criação de relações por parte do espectador. A montagem coordena e multiplica os pontos de vista, promove a atividade indutiva e dedutiva. Por meio da duração dos planos, das repetições e intercalações, das divisões de tela, das incrustrações, ela estabelece conexões, faz ler nas entrelinhas. O raccord é o grande momento escópico do filme: completa, confirma ou retorna ao plano anterior de maneira contraditória a seus atributos. O espectador identifica o conteúdo dos planos, raciocina o porquê das junções temporais e das articulações entre os planos; ou seja, as operações cognitivas são configuradas pela montagem, que é também responsável por dar unidade entre a forma e o conteúdo do filme. O espectador pode, por assim dizer, ver uma descoberta se desenvolver, com as hesitações e contradições que o processo implica, em forma narrativa.

A beleza intrínseca à ciência é aquela que desperta em nós o prazer estético semelhante ao que temos quando da apreciação de uma obra de arte. Ambas respondem a problemas que o mundo nos coloca. São respostas que vão além do objeto estudado, da imagem desenhada, da poesia escrita. A contemplação da arte em qualquer de suas manifestações nos faz abstrair do objeto que se observa; abstração esta que constitui o trabalho do cientista. O encantamento do filme científico é seu inexorável paradoxo: é no clímax da pesquisa que a beleza cinematográfica se desenvolve para além como uma graça sobrenatural. A beleza suprema se identifica ao mesmo tempo com a natureza e com o acaso $\mathrm{O}$ sucesso do cinema científico está na ambivalência documental e ficcional de sua gênese, nas pausas e no movimento, na maleabilidade do tempo.

Em relação aos diferentes públicos, o cinema científico tem graus de assimilação, conforme a especificidade. Um dos primeiros a observar essa graduação foi Jean Painlevé, para quem há filmes cuja reprodução integral interessa apenas aos pares de pesquisa. Há aqueles com um espírito pedagógico, em que um trabalho elaborado de montagem, sonorização e trucagens (ou letreiros) é facilmente assimilado por um público maior. Há também o filme para difusão de um conhecimento novo, ou de um saber já consolidado, mas com perspectiva nova, retratando algum aspecto original. Determinar o público a que se destina é decisivo para uma empreitada bem-sucedida. $\mathrm{O}$ que importa é impulsionar o observador, o espectador, a sentir e a imaginar. O belo é também o estranhamento; não se trata apenas de apreciar, mas também de penetrar no sentido, de conceber e ensaiar ao mesmo tempo.

Neste universo de filmes, encontramos alguns que exploram todos os recursos da linguagem cinematográfica institucionalizada no intuito de demonstrar e convencer; 
mas há também aqueles que não fecham questão sobre determinado tema, deixando ao espectador uma brecha para a indagação. Trata-se de um espaço privilegiado reservado à imaginação, elemento construtor de conhecimento, e de conceder ao espectador, participante da elaboração de sentido, a possibilidade de se distanciar do discurso exclusivamente racional, ou seja, de ir na direção de um pensamento mais plástico, com um alcance outro que não apenas o previsto pelo autor do filme.

$\mathrm{Na}$ análise comparativa entre De Revolutionibus e Nicholas Copernicus, nosso objeto central de estudo, ficou patente o caráter subversivo do primeiro, que foge inteiramente de uma estrutura esperada em filmes de ciência. A transgressão em $D e$ Revolutionibus é poder questionar um certo estado de coisas. Tecnicamente inovador, o filme desenvolveu efeitos especiais e capacitou estudantes de cinema em técnicas experimentais. Realizado em equipe de professores e alunos, é um filme quase todo resolvido na mesa de montagem, uma vez que as imagens foram captadas de modo um pouco desordenado, de acordo com a disponibilidade da equipe. Em alguns momentos, no começo principalmente, o filme soa anacrônico, lento, sem nada de especial em sua proposta de informar. De repente, o choque se apresenta em um corte transversal no tempo-espaço e conduz o espectador ao presente, com a imagem do sol que convoca inevitavelmente à reflexão. Esse choque intencional provocado pela montagem corresponde à mudança nos paradigmas que orientavam a humanidade na Idade Média para a Idade Contemporânea.
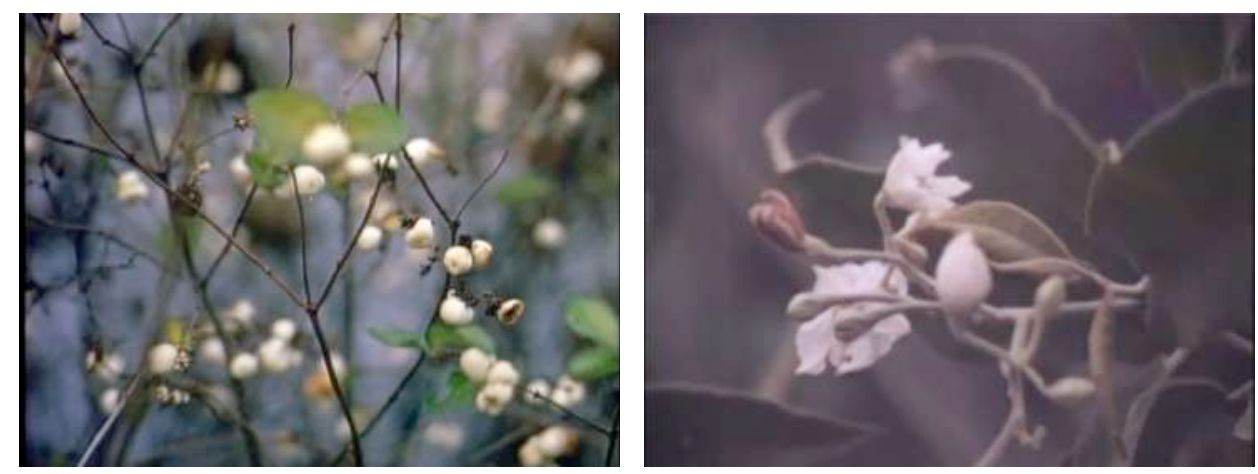

Figuras 143 e 144: Imagens dos filmes Nicholas Copernicus (143) e De Revolutionibus (144), que guardam semelhanças superficiais e diferenças profundas. Nos dois filmes, há momentos que parecem evocar a mesma atmosfera. Mas a montagem é o elemento que expõe a polarização dos discursos visuais.

A ruptura no modo de pensar do Renascimento traduz-se nas opções da montagem, em especial no ritmo do filme. A montagem também opera o movimento 
pendular entre o passado e o presente, embalado por uma trilha cheia de contrastes. $\mathrm{O}$ risco a que se expõe o filme, com os experimentos em animação e com a montagem, resultam em uma obra instigante no estranhamento provocado.

Trata-se de um filme que explora todo potencial da linguagem cinematográfica e amplia as fronteiras do cinema científico em direção ao terreno da imaginação, da criatividade e da poesia. Quando aproxima/contrapõe imagens estáticas da Idade Média a filmagens documentais da paisagem urbana e da música pop, sugere, em subtexto, a plasticidade do pensamento científico e caracterizando um discurso aberto, ou seja, a ciência como um trabalho sempre em andamento. Considerando, então, o conceito de filme heurístico, o contraste fica evidente: De Revolutionibus é um filme provocante e transgressor, antes de ser filme de ensino.

Em Nicholas Copernicus, a abundância de imagens originais de artefatos de época apela à sensibilidade háptica. O deslumbre com o detalhe é uma característica dos Eames, que não deixam nada escapar à observação. A partir de seu olhar de designers, é como se encontrassem nas formas do passado uma plasticidade ancestral, o berço da cultura ocidental moderna. Fora o encanto e a harmonia na sucessão dos planos, o filme não apresenta surpresas e tem uma montagem monótona, com uma narração cronológica, em que o agenciamento das conexões imagéticas restringe-se à contemplação passiva do passado, permanecendo nele - ao contrário de $D e$ Revolutionibus, que salta para o presente, volta ao passado e vislumbra o futuro.

A belíssima trilha sonora acompanha as belas imagens, sem explorar o poder da expressão contrapontística, sem operar oposições nem contrastes, como na sequência da catedral medieval ao som do canto gregoriano, ou das imagens da Itália com uma melodia mais alegre, produzindo um sistema previsível e pobre em significados, apesar da beleza plástica. O tratamento dos Eames em Copernicus é semelhante ao trabalho que realizam em seus filmes anteriores, nos quais a exploração da plasticidade dos objetos - piões, espuma no asfalto, máquina solar - são o elemento central. Eles, os Eames, não assumem riscos.

O núcleo da questão é que o Copernicus dos Eames reverencia o papel e o valor do cientista, mas com o olhar esteta de designers que são, ou seja, um olhar de quem está de fora da questão científica, mais apegado ao aspecto superficial dos artefatos do que à mudança de pensamento que se seguiu à proposição de Copérnico. Já De Revolutionibus expressa a subversão do pensamento do astrônomo pelo conteúdo, pela forma e por todas as instâncias da produção, desde o uso de imagens e trilha sem 
permissão até sua montagem atrevida. Tassara, também astrônomo, caracteriza com profundidade o impacto da revolução copernicana com um olhar de cientista, de quem está por dentro da problemática, o que faz de De Revolutionibus um filme verdadeiramente original.

Podemos deduzir então que, de certa forma, o filme-homenagem deles é um documentário num sentido mais convencional e justo da palavra; enquanto o de Tassara encontra-se mais na linhagem de um filme-ensaio, com certo grau de fabulação, de invenção e de intervenção da subjetividade do realizador no próprio tecido fílmico.

O filme do Tassara seria, portanto, mais complexo e enriquecedor que o do casal Eames já que ele consegue, a despeito das limitações e dos poucos recursos, estabelecer uma relação mais profunda do espectador com a temática e as questões abordadas. Reforça-se a hipótese de que quanto mais inventivo, mais eficaz o filme científico consegue ser, fazendo o espectador extrapolar o nível da mera informação - ou, como diria Roland Barthes o $1^{\mathrm{o}}$ sentido da imagem, aquele associado à fotografia de cunho jornalístico, distinto do $3^{\circ}$ sentido, que ele identifica no cinema toda vez que algum elemento escapa a uma leitura óbvia.

Na relação ciência-cinema, as conexões entre observação e criação são muito ricas na dimensão da linguagem narrativa, contemplando o imaginário do espectador. Comprova-se, nesta pesquisa de doutorado, que as imagens produzidas em De Revolutionibus direcionam não unicamente à grandeza de Copérnico, mas possibilitam ao espectador olhar criativamente o tempo contemporâneo e, com isso, buscar no silêncio as respostas, evitando o barulho de modismos, clichês, dogmas e moralismos. Afinal, uma das desesperanças do mundo contemporâneo fundamenta-se na racionalização generalizada da existência. O extraordinário do cientista Copérnico, do século XVI, e do cinema de Tassara, do século XX, é a busca pelo retorno ao essencial, pelo fluxo das experiências vividas e pelo mistério do ser. 


\section{Referências bibliográficas}

ACADEMY OF NATURAL SCIENCE OF DREXEL UNIVERSITY. Gesner's Historiae Animalium [on-line]. Disponível em: <https://ansp.org/exhibits/onlineexhibits/stories/gesners-historiae-animalium/>. Acesso em: 10 fev. 2020.

ALBERT Londe. Photographic series of a patient diagnosed with hysteria at the La Salpêtrière hospital in Paris (1885) [on-line]. The Charnel-House: from Bauhaus to Beinhaus. Disponível em: $<$ https://thecharnelhouse.org/2013/03/30/hystericalmaterialism/londe_12_pictures-3/>. Acesso em: 10 fev. 2020.

ALLEZAUD, Robert. Les objets fractals, par B. Mandelbrot. Communication \& Langages, vol. 64, n. 1, p. 123-4, 1985.

ANSCHÜTZ Vol cigogne étude 1884 [on-line]. Wikimedia Commons. Disponível em: $<$ https://commons.wikimedia.org/w/index.php?curid=45608954 $>$. Acesso em: $11 \mathrm{fev}$. 2020.

APPENDIX: Electron Microscopes [on-line]. Doctor C' On Line Histology. Disponível em: <http://www.doctorc.net/Labs/Lab2/Appendix/ems.htm>. Acesso em: 6 fev. 2020.

ARNHEIM, Rudolf et al. Arte \& percepção visual: uma psicologia de visão criadora. São Paulo: Cengage Learningm, 1980.

AUMONT, Jacques. A estética do filme. Tradução de Marina Appenzeller. São Paulo: Papirus, 2009 [1995].

AUMONT, Jacques; MARIE, Michel. A imagem. Tradução Estela dos Santos Abreu e Cláudio C. Santoro. São Paulo: Papirus, 1993.

AVANCINI, Atílio. A imagem fotográfica do cotidiano: significado e informação no jornalismo. Brazilian Journalism Research, vol. 7, n. 1, 2011, p. 50-68.

BACHELARD, Gaston. A formação do espírito científico. Rio de janeiro: Contraponto, 1996 [1938].

La poétique de la rêverie. Paris: Presses Universitaires de France, 1968.

BAIONE, Tom (Ed.). Natural histories: extraordinary rare book selections from the American museum of natural history library. Sterling Signature, 2012.

BARBOSA JR., Alberto Lucena. Arte da animação: técnica e estética através da história. São Paulo: Senac, 2005.

BARTHES, Roland. O óbvio e o obtuso. Rio de Janeiro: Nova Fronteira, 1990 [1982].

A câmara clara: nota sobre a fotografia. Tradução de Júlio Castañon Guimarães. Rio de Janeiro: Nova Fronteira, 1984. 
BAZIN, André. Écrits complets I et II. Paris: Macula, 2019.

O cinema: ensaios. São Paulo: Brasiliense, 1991.

. Beauté du hasard: Le film scientifique. L’Écran Français, n. 121, 1974, p. 10.

. Quand les microbes jouent les vedettes - un festival méconnu: celui du film

scientifique. Le Parisien Libéré, n. 953, 10 oct. 1947.

BEATRIX Potter - Micology [on-line]. Wikipedia. Disponível em: $<$ https://en.wikipedia.org/wiki/File:Beatrix_Potter-_Mycology._Source-

_Armitt_Museum_and_Library.jpg>. Acesso em: $10 \mathrm{fev} .2020$.

BERGSON, Henri. Durée et simultanéité. Paris: PUF, 2009 [1922].

BRAUN, Marta. Muybridge, Authorship, Originality. Early Popular Visual Culture, vol. 11, n. 1, 2013, p. 41-51. Disponível em: $<$ https://www.tandfonline.com/doi/figure/10.1080/17460654.2012.756644?scroll=top\& needAccess $=$ true \& $>$. Acesso em: 20 fev. 2020.

BULL, Lucien. La cinématographie. [S.1]: Librairie Armand Colin, 1928.

CALCAGNO-TRISTANT, Frédérique. Jean Painlevé et le cinéma animalier. Un processus d'hybridation engagé. Communication. Information Médias Théories Pratiques, vol. 24, n. 1, 2005, p. 117-49.

CASTRO, Teresa. O impulso cartográfico do cinema. Intervalo, p. 23, 2015.

CAUDA, Ernesto. Il cinematografo al servizio della scienza. [S.1.]: Edizioni di "Quadrante", 1935.

COMENII, Johannis Amos. Orbis Sensualium Pictus. London: [s.n.], 1993 [1659].

CHARCOT, Jean Martin; FREUD, Sigmund. Neue Vorlesungen über die Krankheiten des Nervensystems, insbesondere über Hysterie. Leipzig: Toeplitz \& Deuticke, $1886 . \quad$ Disponível em: $<$ https://archive.org/details/neuevorlesungen00freugoog/page/n239/mode/2up $>$. Acesso em: 10 fev. 2020.

CLOUD Chamber Photograph of the First Positron Ever Observed by C. Anderson [online]. Wikipedia. Disponível em: $<$ https://en.wikipedia.org/wiki/Cloud_chamber\#/media/File:PositronDiscovery.jpg $>$. Acesso em: 10 fev. 2020.

COMENIUS, Johann Amos. Orbis Sensualium Pictus. [S.1.]: [s.n.], 1705. Disponível em: <https://digital.collections.slsa.sa.gov.au/nodes/view/2177>. Acesso em: 10 fev. 2020 .

COPERNICUS, Nicolaus. De Revolutionibus Orbium Caelestium. Sumptibus Societatis Copernicanae, 1873. 
CORTADE, Ludovic. The "microscope of time": slow motion in Jean Epstein's writings. In: KELLER, Sarah; PAUL, Jason N. Jean Epstein: Critical Essays and New Translations. Amsterdã: Amsterdan University Press, 2012.

CURTIS, Scott. The Shape of Spectatorship: Art, Science, and Early Cinema in Germany. New Yor: Columbia University Press, 2015.

DA VINCI, Leonardo. The notebooks of Leonardo da Vinci. New York: Dover, 2012.

DAGUERREOTYPE: I.15 1874-1874 [on-line]. Daguerreobase. Disponível em: $<$ http://www.daguerreobase.org/en/type/e158f3ce-ee2c-7d25-f142-e8ee910ef41f $>$.

Acesso em: 10 fev. 2020.

DASTON, Lorraine; GALISON, Peter. Objectivité, Paris: Les Presses du réel, 2010.

DEMAZEL, Florence Le. Images et valeurs du travail [on-line]. Débord et ments, 27 jul. 2016. Disponível em: $<$ https://www.debordements.fr/Images-et-valeurs-du-travail $>$. Acesso em: 11 fev. 2020.

DESCLAUX, Pierre. Le cinéma au service la science. Cinémagazine, n. 2, 28 jan.-3 fev., 1921, p. 10-6.

DESLANDES, Jacques; RICHARD, Jacques. Histoire comparée du cinéma. Paris, Casterman, 1966.

DONALDSON, Leonard. The Cinematograph and Natural Science: the Achievements and Possibilities of Cinematography as an Aid to Scientific Research... and a Supplement. [S.1.]: Gane s, Limited, 1912.

DONDERO, Maria Giulia. L'image scientifique: de la visualisation à la mathématisation e t retour. AS-Actes Sémiotiques, 2009.

DR. DOYEN Separating Hindoo Twins [on-line]. Wikipedia. Disponível em: $<$ https://upload.wikimedia.org/wikipedia/commons/d/d8/The_Library_of_Congress__Dr._Doyen_separating_Hindoo_twins_\%28LOC\%29_\%28pd\%29.jpg $>$. Acesso em: 10 fev. 2020.

DUARTE, B.J. O filme científico. Filme Cultura, Rio de Janeiro, n. 14, 1970.

DUCOM, Jacques. Le cinématographe scientifique et industriel. Son évolution intellectuelle, sa puissance éducative et morale. Traité de cinématographie. Paris, Albin Michel, 1924.

DULAC, Germaine. L’art cinématographique. [S.1.]: Libreairie Félix Alcan, 1927.

EISENSTEIN, Sergei. O sentido do filme. Trad. Teresa Ottoni. Rio de Janeiro: Jorge Zahar Editor, 1990.

EPSTEIN, Jean. Esprit de cinéma. [S.1.]: Jeheber, 1955.

ESCOUBE, Lucienne. Le cinéma et la science. Cinémagazine, Paris, n 30, p. 1928. 
. Le cinéma scientifique - Naissance du cinéma. De Janssen à Marey. La Revue du Cinéma, n. 25, 1931, p. 67.

ÉTIENNE-JULES Marey (1830-1904) [on-line]. Hardgrave: the Pioneers. Disponível em: <http://www.ctie.monash.edu.au/hargrave/marey.html $>$. Acesso em: 10 fev. 2020.

FERNANDES, Conchita. Étienne-Jules Marey [on-line]. Better Photography, 30 jan. 2017. Disponível em: <http://www.betterphotography.in/perspectives/greatmasters/etienne-jules-marey/48592/>. Acesso em: 10 fev. 2020.

FOREST, Denis. Fatigue et normativité. Revue Philosophique de la France et de l'Etranger, vol. 126, n. 1, 2001, p. 3-25.

FOUCAULT, Michel. Foucault Live (Interviews 1961-1984) ed. Sylvere Lotringer, trans. Lysa Hochroth and John Johnston. Semiotext (e), 1996.

GARCIA, Gabriel Cid; COIMBRA, Carlos A. O. Ciência em foco: o olhar pelo cinema. Rio de Janeiro: Garamond, 2008.

GAYCKEN, Oliver. Devices of Curiosity: Early Cinema and Popular Science. [S.1.]: Oxford University Press, 2015.

GESSNER, Conrad et al. Historiae animalium Libri V. Laurentius.

GUIDI, Mario Arturo Alberto. De Altamira a Palo Alto: a busca do movimento. São Paulo, Escola de Comunicações e Artes (ECA/USP), 1991.

HAMBURGER, E. W. ; GEBARA, N. ; MORAES, J. N. B.; MURAMATSU, M. ; SOARES, V. L. L. ; TASSARA, E.; ZANETIC, J. Avaliação de Filmes Didáticos de Física. Revista Brasileira de Fisica, vol. 3, n.3, 1974, p. 603-18.

HAMERY, Roxane. Le cinéma scientifique et l'enregistrement des couleurs naturelles: des expériences pionnières à la norme. Revue de l'association française de recherche sur l'histoire du cinéma, n. 71, 2013, p. 229-52.

HARRIS, Moris. Prismatic Colour Wheel. In: The Natural System of Colours [on-line]. London: [s.n.], [1785]. Disponível em: <https://www.royalacademy.org.uk/artartists/work-of-art/prismatic-colour-wheel>. Acesso em: 10 fev. 2020.

HAYES, Brian. Father of Fractals. American Scientist, vol. 101, n. 1. jan.feb. 2013, p. 60. DOI: $10.1511 / 2013.100 .60$

HENRY, John. A revolução científica. Rio de Janeiro: Jorge Zahar, 1998.

HIGH Energy Theory [on-line]. Disponível em: $<$ http://particle.physics.ucdavis.edu/Graphics/rotate/images.php $>$. Acesso em: 10 fev. 2020.

HISTORIAE Animalium (Gerssner) [on-line]. Wikipedia. Disponível em: $<$ https://en.wikipedia.org/wiki/Historia_animalium_(Gessner)\#/media/File:Historiae_an imalium_1551_De_Monocerote.jpg >. Acesso em: 10 fev. 2020. 
HOOKE, Robert. Micrographia: or Some Physiological Descriptions of Minute Bodies Made by Magnifying Glasses, with Observations and Inquiries Thereupon. [S.1.]: Courier Corporation, 2003.

INFECTED T Lymphocyte. Hybrid: Medical Animation [on-line]. Disponível em: $<$ https://www.hybridmedicalanimation.com/work/illustration/infected-t-lymphocyte/>. Acesso em: 11 fev. 2020.

KERMOYAN, Mireille. L'Office National du Film - Canada. La Science à l' écran. Cinémaction, n. 38, 1985.

KIRKHAM, Pat. Charles and Ray Eames: Designers of the Twentieth Century. Massachusset: MIT Press, 1998.

KITZ, Sebastian. Dynamische Geometrie ohne Computer: Die mathematischen Trickfilme des Geheimen Schulrats Münch. Mathematische Semesterberichte, vol. 60, n. 2, 2013, p. 139-49.

KOESTLER, Arthur. O homem e o universo. Trad. Alberto Denis. São Paulo: Ibrasa, 1989 [1938].

LANGLOIS, Henri. Hommage à Jules-Étienne Marey, Cinémathèque française, Musée du cinéma, Palais de Chaillot, 1963, p.[4].

LATOUR, Bruno. Ciência em ação: como seguir cientistas e engenheiros sociedade afora. São Paulo: Ed. da Unesp, 2000.

LEFEBVRE, Thierry. Les débuts du cinéma scientifique: quelques jalons. Cinémaction, n. 135, Du film scienfifique et technique, co-dirigé par Philippe Dériaz et Nicolas Schimidt. Cerf, 2010.

Les Joyeux Microbes: un film sous influence?. 1895. Mille huit cent quatrevingt-quinze. Revue de l'association française de recherche sur l'histoire du cinéma, n. 53, 2007, p. 168-79.

LIESEGANG, F. Paul. Wissenschaftliche Kinematographie: Einschl. d. Reihenphotogr. Unter Mitarb. v. Karl Kieser u. Oswald Polimanti. Mit 146 Abb. Ed. Liesegang, 1920.

LUCIEN Bull. Monsieur Cent Mille Images [on-line]. La France en Irlande: culture et sciences, 25 abr. 2016. Disponível em: <https://ie.ambafrance.org/Lucien-BullMonsieur-Cent-Mille-Images>. Acesso em: 10 fev. 2020.

MACFARLANE, Alan. An Interview with Owen Gingerich [audiovisual, on-line]. 15 dez. 2008. Disponível em: <https://youtu.be/NGpviAHXQnc>. Acesso em: 5 fev. 2020.

MACHADO, Arlindo. O cinema científico. Significação: Revista de Cultura Audiovisual, vol. 41, n. 42, p. 15-29, 2014.

. Pré-cinemas \& pós-cinemas. São Paulo: Papirus, 1997.

MANDELBROT, Benoit B. Les fractales: Objets mathématiques, modèles physiques et créations artistiques. In: $1^{\circ}$ Colloque Image: traitement, synthèse, technologies et 
applications, FRA, 1984. GRETSI, Groupe d'Etudes du Traitement du Signal et des Images, 1984.

MANNONI, Laurent. Les Collections photographiques de la Cinémathèque française. Études Photographiques [on-line], 16 maio 2005. Disponível em: $<$ https://journals.openedition.org/etudesphotographiques/737>. Acesso em: 9 jan. 2020.

MAREY, Etienne-Jules. La Chronophotographie. [S.1]: [s.n.], 1985.

. Le mouvement. [S.1.]: Masson, 1894.

Zootrope dans lequel sont disposées dix images en relief d'un goéland dans les attitudes successives d'un vol. [S.1].: [s.n.], 1887. Disponível em: $<\mathrm{http}$ ://www.artnet.com/artists/etienne-jules-marey/zootrope-dans-lequel-sontdispos\%C3\%A9es-dix-images-en-rFaKZphaR8O1AI-zQmmw2w2>. Acesso em: 10 fev. 2020.

La méthode graphique dans les sciences expérimentales et princi palement en physiologie et en médecine. [S.1.]: G. Masson, 1878.

MARQUES, Maria Luiza Dias de Almeida. A transição do modo de produção analógico para o digital nas produtoras de animação publicitária: o impacto da tecnologia no cinema de animação. São Paulo, 2014. Dissertação de Mestrado. Universidade de São Paulo.

MARTINI, Matteo; FONTANA, Fabrizio. The PSSC Didactic Movies, Some "Old Friends" Revisited through Modern Teaching Technologies. Digital Universities, vol. 2, 2015: International best practices and applications, n. 2-3, p. 67, 2016.

MAX Ernst [on-line]. East of Borneo, 17 mar. 2011. Disponível em: $<$ https://eastofborneo.org/archives/max-ernst/>. Acesso em: 10 fev. 2020.

MEDAWAR, Peter Brian. Advice to a YOUNG SCIENTIST. [S.1.]: Basic Books, 2008.

MICHAELIS, Anthony. Research Films in Biology, Anthropology, Psychology, and Medicine. [S.1.]: Elsevier, 2012.

MICROGRAPHIA by Robert Hooke, 1665 [on-line]. Disponível em: $<$ https://www.bl.uk/collection-items/micrographia-by-robert-hooke-1665>. Acesso em: 30 jan. 2020.

MIND Maps: the Beauty of Brain Cells - in Pictures [on-line]. The Guardian, 18 jan. $2017 . \quad$ Disponível em: $<$ https://www.theguardian.com/artanddesign/gallery/2017/jan/18/santiago-ramon-ycajal-mind-maps-the-beauty-of-brain-cells-in-pictures>. Acesso em: 10 fev. 2020.

MITCHELL, W. J. T. Picture Theory. [S.1.]: The University of Chicago Press, 1994.

MORAES, Alice Ferry de. Humberto Mauro - Cineasta da Saúde. Revista Eletrônica de Comunicação, Informação e Inovação em Saúde, vol. 5, n. 1, 2011. 
MOVEMENTS of Air Etienne-Jules Marey - Photographer of Fluids [on-line]. Kjulm, 14 oct. 2012. Disponível em: <http://kjulm.blogspot.com/2012/10/movements-of-airetienne-jules-marey.html>. Acesso em: 10 fev. 2020.

MURAMATSU, Mikiya. Produção, utilização e avaliação de filmes didáticos de Física. 1976. Dissertação de mestrado.

MUYBRIDGE, Eadweard. Animal locomotion. [S.1.: Da Capo Press, 1887.

NETTO, Domingos Luiz Bargmann. Produção audiovisual na Universidade de São Paulo. 2000. Tese de Doutorado.

NORDAU, Max Simon. Degeneration. London: William Heinemann, 1895

O'GOMES, Do et al. Le cinéma scientifique: L'œuvre de Doyen, Thévenard et Comandon. Gazette des archives, vol. 173, n. 1, 1996, p. 183-9.

OKADA, Sozo. Science on the Screen. Japan Quarterly, vol. 11, n. 4, 1964, p. 476.

ORGERON, Marsha; STREIBLE, Dan (eds.). Learning with the Lights off: Educational Film in the United States. [S.1]: Oxford University Press, 2011.

PAINLEVÉ, Jean. Cinéma et recherche. [S.1.]: Librairie du Palais de la Découverte, 1956.

PANOFSKY, Erwin. Significado nas artes visuais. São Paulo: Editora Perspectiva, 1976.

PARRA, Nélio. Metodologia dos recursos audiovisuais: estudo fundamentado na psicologia genética de Jean Piaget. São Paulo: Saraiva, 1973.

PASSAGE de Venus: Series of Photographs of the Transit of the Planet Venus across the Sun in 1874 [on-line]. Internet Movie Database (imdb). Disponível em: $<$ https://www.imdb.com/title/tt3155794/mediaviewer/rm3613616128>. Acesso em: 10 fev. 2020.

PERSONS, Collections and Topics: Hooke, Micrographia (1665) [on-line]. Hunt Institute for Botanical Documentation. Disponível em: $<$ http://www.huntbotanical.org/library/show.php?9>. Acesso em: 11 fev. 2020.

PIAGET, Jean. Psichologie et pédagogie. Paris: Gonthier, 1969.

PIERRE Senges: une trajectoir [on-line]. Remue. Disponível em: $<$ http://remue.net/Pierre-Senges-Une-trajectoire>. Acesso em: 10 fev. 2020.

PRINCE Albert I of Monaco and a Sperm Whale [on-line]. Wikipedia. Disponível em: $<$ https://upload.wikimedia.org/wikipedia/commons/1/18/Prince_Albert_I_of_Monaco_a nd_a_sperm_whale.jpg >. Acesso em: 10 fev. 2020. 
REINHOLD, Robert. After 500 Years, Now the Year of Copernicus. New York Times, 28 dez. 1972. Disponpivel em: <https://www.nytimes.com/1972/12/28/archives/after500-years-now-the-year-of-copernicus-after-500-years-now-the.html $>$. Acesso em: 5 fev. 2020.

ROMANESCO brassica oleracea Richard Bartz [on-line]. Wikimedia Commons. Disponível em: $<$ https://commons.wikimedia.org/wiki/File:Romanesco_Brassica_oleracea_Richard_Ba rtz.jpg>. Acesso em: 11 fev. 2020.

ROSA, João Guimarães. Grande sertão: veredas. São Paulo: Companhia Das Letras, 2019.

ROUCHE, Jean. L'itineraire initiatique. La Science à l'écran, n. 38, 1986.

ROYAL COLLECTIUM TRUST. Metamorphosis insectorum Surinamensium [online]. Disponível em: <https://www.rct.uk/sites/default/files/collection-online/5/b/>. Acesso em: 10 fev. 2020.

RUDOLPH, John L. PSSC in Historical Context: Science, National Security, and American Culture during the Cold War. American Association of Physics Teachers, 2006.

SADOUL, Georges. Histoire du cinema mondial des origines à nos jours. Paris: Flammarion, 1964.

SAGAN, Carl. Cosmos. 1980. Trad. Maria Auta de Barros, e Isabel Pereira dos Santos. Lisbo a: Gradiva, 1981.

SCATLIFF, Jim H.; JOHNSTON, Jill. Andreas Vesalius and Thomas Willis: Their Anatomic Brain Illustrations and Illustrators. American Journal of Neuroradiology, vol. 35, n. 1, jan. 2014, p. 19-22. DOI: https://doi.org/10.3174/ajnr.A3766

SCHIERMEIER, Quirin. Germany's institute for scientific film could face final curtain [on-line]. Nature, vol. 391, n. 425, 1998, Disponível em: $<$ https://www.nature.com/articles/34995>. Acesso em: 10 fev. 2020.

SCHMIDT, Nicolas; DÉRIAZ, Philippe. Du film scientifique et technique. [S.1]: [s.n], 2010.

SCHULDENFREI, Eric. The Films of Charles and Ray Eames: A Universal Sense of Expectation. [S.1.]: Routledge, 2014.

SCRIVE, Martine. Le film d'exposition scientifique, un choc entre deux cultures. ASTE, n. 9, 1989. DOI : https://doi.org/10.4267/2042/9143

SERIES of Photos Showing a Hysterical Yawning Woman [on-line]. Wikimedia Commons. Disponível em: $<$ https://commons.wikimedia.org/wiki/File:Series_of_three_photos_showing_a_hysteric al_yawning_woman_Wellcome_L0034940.jpg >. Āeesso em: $10 \mathrm{fe} \overline{\mathrm{V}} .2020$. 
TCHERNEVA, Irina. Légitimité scientifique et pédagogique du cinéma de "vulgarisation scientifique" en Union soviétique (1930-1970). Le Telemaque, n. 1, 2018, p. 47-62.

TERNAY, Jean-François. L'image et la recherche: voir-mésurer-simuler. Cinémaction, n. 135, Du film scienfifique et technique, co-dirigé par Philippe Dériaz et Nicolas Schimidt. Cerf, 2010.

TOP cot [on-line]. Wikimedia Commons. Disponível em: $<$ https://commons.wikimedia.org/wiki/File:Top_cot.jpg>. Acesso em: 11 fev. 2020.

TOSI, Virgilio. Cinema before Cinema. London: British Universities Film and Video Council, 2005

UEBERSCHLAG, Josette. Le film d'enseignement des sciences et des techniques. Cinémaction, n. 135, Du film scienfifique et technique, co-dirigé par Philippe Dériaz et Nicolas Schimidt. Cerf, 2010.

. Le film à intention heuristique, un media en faveur de l'apprentissage des sciences: approche du concept au niveau de l'école élémentaire. 2003. Tese de Doutorado. Dijon.

VAN DYKE, Milton. An album of fluid motion. [S.1.]: [s.n.], 1982.

VAZ, Valteir. Em defesa do insólito: Viktor Chklóvski e Guimarães Rosa. RUS (São Paulo), v. 3, n. 3, p. 44-52, 2014.

VESALIUS, Andreas. De humani corporis fabrica. [S.1.]: Norman Publishing, 1999.

VICENTE, Tania Aparecida de Souza. Metodologia da análise de imagens. Revista Contrac ampo, n. 04, 2000.

VIVIÉ, J. Traité général de technique du cinéma. v.1: Historique et développement de la technique cinématographique. Paris: Éditions BPI, 1946.

VON GOETHE, Johann Wolfgang. Theory of colours. Massachusset: Mit Press, 1840.

WESTMAN, Robert. Copernicus. Encyclopedia Britannica [on-line]. Disponível em: $<$ https://www.britannica.com/contributor/Robert-S-Westman/4339>. Acesso em: 12 fev. 2020 .

WHEN the bubble chamber first burst onto the scene [on-line]. Cern Couries, 29 apr. 2001. Disponível em: $<$ https://cerncourier.com/a/when-the-bubble-chamber-first-burstonto-the-scene/>. Acesso em: 11 fev. 2020.

WINGSTEDT, John (2005). Narrative Music: Towards an Understanding of Narrative Music in Multimedia. Disponível em: <http://epubl.ltu.se/1402-1757/2005/59/LTULIC-0559- SE.pdf>. Acesso em: 5 dez. 2019.

YOUNGBLOOD, Gene; FULlER, Richard Buckminster. Expanded Cinema. New York: Dutton, 1970. 
ZÖLLNER, Frank. Leonardo da Vinci - Desenhos e esboços. [S.1]: [s.n.], 2005.

\section{Filmografia}

A Boy and his Atom, IBM research (2013)

A medida do tempo, Jurandyr Passos (1958)

Água limpa, Igino Bonfioli e Fábio Horta (1958)

Assassins d'eau douce, Jean Painlevé (1947)

Cels in Culture, Michael Abercrombie (1958)

Cosmic Zoom, Eva Szasz, (1969)

Crisi d'isteria, Roberto Omegna, (1908)

Das Blumenwunder, Max Reichmann, (1926)

De Revolutionibus, Marcello Tassara (1973)

Derive des continentes, Co Hoedeman (1969)

Encyclopaedia Cinematographica Demo-Video, Institute for Scientific Film Göttingen (década de 1950)

HIV Budding from Host Cell, Hybrid Medical Animation (2018)

$\mathrm{H}_{2} \mathrm{O}$, Guy Lebrun (1960)

Impulsão, centro de massa, energiômetro, Marcello Tassara (1972)

La Croissance des vegetaux, Jean Comandon (1929)

Le Vampire, Jean Painlevé (1945)

L’Hippocampe, Jean Painlevé (1934)

Mathematische Trickfilm, Ludwig Münch (1912)

Nicholas Copernicus, Ray e Charles Eames (1973)

Numeric Variations, Instituto de Matemática e Artes de São Paulo (2015)

Passage de venus, Pierre Jules César Janssen (1874)

Science is Fiction, The Films of Jean Painlevé (2007)

Serpentine dance, Louis e Auguste Lumière (1899) 
The Act of Seeing with One's Eyes, Stan Brakhage (1971)

The World of Microbes, Tokyo Cinema Co. (1958)

The World of Pulses, Tokyo Cinema Co. (1962)

Time Lapse Salamander Development, Yale University (1920)

Um cão andaluz, Luis Buñuel e Salvador Dalí (1928)

Univers, Roman Kroitor e Colin Low (1960)

Vida de bolacha, Bruno Velutinni (2010)

\section{Sites}

http://bases.cinemateca.gov.br

http://www.afana.org/everotepssc.htm

https://www.brainpickings.org/2012/11/27/natural-histories/

http://www.eamesoffice.com/the-work/copernicus-exhibition/

https://www.nytimes.com/1972/12/28/archives/after-500-years-now-the-year-ofcopernicus- after-500-years-now-the.html

http://www.vam.ac.uk/content/articles/b/beatrix-potter-natures-lessons/

http://www.bbc.com/earth/story/20160215-beatrix-potter-pioneering-scientist-orpassionate- amateur

http://www.chartes.psl.eu/fr/positions-these/leon-gaumont-pionnier-meconnu-ducinema- 1864-1929

https://www.nationaltrust.org.uk/features/between-naturalism-and-fantasy-the-art-ofbeatrix- potter

https://www.nature.com/articles/34995 (Germany's institute for scientific film could face final curtain)

https://www.interviewmagazine.com/art/david-hockney

https://remedianetwork.net/2017/01/16/the-backstage-of-hysteria-medicine-in-thephotographic-studio/

http://www.eadweardmuybridge.co.uk/muybridge_image_and_context/california_lands cape/

http://www.lilienthal-museum.de/olma/me507.htm 
https://lejournal.cnrs.fr/nos-blogs/les-yeux-de-la-science/letude-des-courants-dair

https://www.musee-orsay.fr/fr/evenements/expositions/aux-musees/presentationdetaillee/page/3/article/mouvements-de-lair-etienne-jules-marey-1830-1904photographe-des-

fluides-

4216.html?tx_ttnews\%5BbackPid\%5D=649\&cHash=6e68735f87

https://www.biusante.parisdescartes.fr/histoire/medica/doyen-en.php

http://www.ctie.monash.edu.au/hargrave/marey.html

https://home.cern/news/news/experiments/seeing-invisible-event-displays-particlephysics

http://www.compadre.org/portal/pssc/pssc.cfm

http://www.doctorc.net/Labs/Lab2/Appendix/ems.htm

https:/www.ibm.com/ibm/history/ibm100/us/en/icons/fractal/words/ 
ANEXO I - Transcrição da entrevista com Marcello Tassara (10/04/2017)

(participação ocasional Eda Tassara)

\section{Relato a respeito do filme De Revolutionibus}

M.T. Chamava-se Halina a esposa do Rudá. Polonesa. Pessoa que tinha problemas, ótima pessoa, Foi por causa do Rudá que eu acabei entrando na USP.

Porque o curso foi montado, os primeiros professores não eram nem pessoas da academia. Tinha o Paulo Emílio, que era já doutor, aliás, não era nem doutor o Paulo Emílio, naquela época. Não tinha professores na USP especializados em cinema (1: 54). Então, o Rudá convidou o Roberto Santos pra organizar este departamento. Não sei se foi o Rudá que chamou o Roberto Santos ou vs. Os dois foram a semente principal do curso de cinema.

O Paulo Emílio foi integrado, depois teve outros professores, o Charles Fernando de Almeida, que montou o João Guimarães Rosa, o Jorge Bodanzky, diretor de fotografia e tantas outras pessoas que eram profissionais da área de cinema, mas que não tinham diplomas completos na área acadêmica, não tinham títulos.

Entre esses profissionais, estava eu, eu fui chamado, fui convidado porque tinha feito o filme A João Guimarães Rosa. Fui convidado pelo Roberto Santos pra fazer. (03:06). Curiosamente, eu tinha diploma de física, então, dessa turma toda, eu era o único que tinha um diploma. E pude ser contratado pra ser professor na USP. Os outros acabaram se desligando porque tinham que fazer pos-graduação, etc, era muito complicado. Os professores que vieram depois já eram ex-alunos nossos, o Ismail, a Dora, a Marília, e tantos outros,

O Roberto, que era um realizador inveterado, sujeito que não podia ver um filme, que já queria fazer outro, ele incentivou muito o Rudá - e o diretor da ECA na época, o Antonio Guimarães Ferri - a realizar um filme dentro do departamento. Para demonstrar que era possível, dentro da Universidade de São Paulo fazer filmes. Como eu já conhecia o Roberto por outros caminhos, ele era um profissional com o qual eu trabalhei muitas vezes, ele acabou me convidando pra realozar o filme A João Guimarães Rosa, que foi o primeiro filme feito efetivamente pela ECA. Não posso dizer historicamente que tenha sido o primeiríssimo filme feito na USP, (04:41), porque na Faculdade de Educação parece que tem algumas coisinhas que andaram sendo feitas. Nada de concreto, mais experiências sem consequência. Agora, o primeiro filme feito cabalmente, caracterizado como filme, foi o nosso. E foi a partir daí que eu fio convidado a participar da disciplina de Cinema de Animação.

O Copérnico, é o segiunte, a história do Copérnico: O Rudá tinha se casado com a Halina que era uma pessoa extremamente simpática. Ela era polonesa. Em função desse 
conhecimento que tinha a ver com Polônia, por coincidência, na época foi o centenário do - nunca me lembro se é nascimento ou morte - (* É DE NASCIMENTO) do Copérnico, que era polonês. Então o Rudá teve a ideia de fazer um filme sobre o Copérnico, eu não sei se pra agradar a Halina, isso não vem ao caso, ele tem uma relação com a Polônia de alguma forma. (06:53) Ao mesmo tempo em que este filme estava sendo proposto e realizado, o Roberto Santos estava fazendo um filme "As 3 mortes de Solano", o longa-metragem que foi feito na USP, com a história da Lygia Fagundes Telles. Antecipando um pouquinho, o Stênio Garcia, na época, era ator do filme. E eu aproveitei a ocasião, para pedir ao Stênio Garcia que fizesse a voz do Copérnico no filme. Foi uma circunstância favorável que me permitiu que o Stênio Garcia fizesse esse trabalho. Ele já era um ator conhecido na época. Aí, então, nós começamos a fazer esse filme. Só que começou a ficar difícil porque não estava muito claro, porque o INC (que depois se transformou na EMBRAFILME) (08:16), tinha dado um dinheito pra ECA pra fazer esse filme. O Rudá tinha conseguido isso aí. Mas acontece que o filme não saía da gaveta, porque as pessoas não estavam entendendo muito bem o tema, estava complicado.Inclusive, tinha já coisas filmadas, umas coisinhas filmadas, mas 'tava enguiçado o filme, né? (08:46),

Pergunta - quanto tempo ficou enguiçado, desde que conseguiu o dinheiro?

M.T. - AH, uns bons meses, uns 6, 7 meses. Uma avaliação muito superficial.

Mas aí, o INC começou a ficar bravo com a questão porque o filme não saía, eles tinham dado o dinheiro e o filme não saía. E chegaram a ameaçar a USP e denunciar o contrato, o convênio que tinha sido feito. E isso seria uma coisa gravíssima pra ECA. Pra USP de um modo geral e particularmente pra ECA. Aí entro eu, né (09:38) eu 'tava já mais ou menos entrosado nesse filme. Não havia quem assumisse a direção do filme efetivamente; precisava que alguém dissesse "eu sou o diretor do filme eu faço o filme".

M.L.- Era um projeto visto como um abacaxi, pelo povo da ECA?

M.T. - Não era visto como um abacaxi; era visto como um monstro instransponível, uma montanha intransponível.

M.L. - muito pior que um abacaxi, então?

M.T. - Talvez... enfim, era um obstáculo, uma dificuldade que as pessoas não sabiam como ultrapassar. Mas aí, de vez em quando a gente tem esses lances, né, eu, como tinha uma certa paixão, tenho uma paixão por esse tema, principalmente astronomia, (10:34), astrofísica, etc, então eu falei: "Eu assumo a direção do filme". Eu faço o roteiro e termino a direção do filme. A partir daí o INC já 'tava em cima, já estava disposto a denunciar o convênio; então, que que eu fiz? Eu arrumei uma verba lá na ECA, fui até o RJ, onde era a sede no INC e me comprometi pessoalmente a terminar o filme. TRECHO USADO Então, eles me deram um prazo. Não me lembro se foi um 
mês, ou dois, ou coisa assim, pra terminar o filme. Era pouco tempo, era um tempo bem curto.

Mas já havia alguma coisa, já tinha sido feita alguma coisa. Então, eu reuni o pessoal, reunimo-nos, escrevemos um esboço de roteiro, Tinha o Ismail, a Eda, tinha eu, eu não me lembro mais, tinha outras pessoas. Fizemos o esboço, a partir desse esboço do roteiro, que foi um trabalho de pesquisa, sério, que foi levantado; levantamos textos, aqui, ali, tanto que tem textos do próprio Copérnico (12:16) que nós fomos buscar no livro "De Revolutioibus Orbium Coelestium", pegamos isto, estabalecemos um roteiro, e a Dora Mourão foi indicada, se não me engano era o Peñuela, na época, o diretor, foi indicada como montadora do filme,

Só que, como o filme era bastante complexo o que eu fiz? Eu, que tinha uma experiência em cinema de animação, vc sabe muito bem que o animador faz o filme antes de sentar na mesa de animação, ele faz tudo na cabeça, depois ele vai lá e realiza. Então, eu fiz um roteiro absolutamente decupado, assim, até medida de duração de 1 min, 1 seg., $10 \mathrm{seg}$ daqui, $5 \mathrm{seg}$ disso, cronometrado, tudo certinho como se fosse uma ficha de animação. Não era aninação, o filme tem algumas coisas de animação, mas o filme não é um filme de animação, então nós, na ilha de edição, a edição foi rápida, relativamente rápida, porque foi só emendar um pedaço atrás do outro. Aí eu falava assim por brincadeira: "Dora, pega 2 metros de sol, rsrs, 5 metros de cidade de SP, assim por diante, entendeu, foi uma montagem bastante rápida, mas foi precedida de todo um trabalho de decupagem feito cronometricamente medido com o texto. (14:26)

Antes disso houve um período de filmagem, né, a gente filmou com o Chico Botelho e a Ella Durst, eles filmaram comigo várias coisas, nós estivemos no centro da cidade, tem cenas no centro da cidade, tem pôr do sol na ponte da cidade universitária, tem uma série de coisas que 'tava previsto, que tinha que ser filmada...tem as flores, no campo das flores; o episódio do campo das flores tem uma curiosidade. Me lembra que depois eu te conto. (15:00).

Enfim, eu tinha todas as cenas filmadas de acordo com a primeira ideia, o primeiro roteiro que foi feito, eu sabia que material eu tinha na mão, muita coisa eu filmei, na mesa de animação, fotografias, imagens do Copérnico, do Galileo, enfim, tantas outras coisas filmadas também, tem algumas coisinhas, alguns efeitos de animação, né, e teve uma filmagem muito especial, que foi realizada no Planetário de SP. Foi a mais demorada das filmagens e foi a mais difícil. Isso já estava pronto quando eu recebi o prazo já tinha sido filmada. (16:05)

O Planetário de SP, qualquer planetário, porque, vc sabe como é, né, ele projeta uma uma abóbada, uma meia esfera por dentro ele projeta os astros, o movimento dos astros, e é uma máquina automática, é um grande relógio, por exemplo, se ve liga o planetário e faz o sol, por exemplo, se mover ao longo da eclítica, ou o percurso diurno do sol, desde o nascer do sol até o pôr do sol, o que que acontece? Os mecanismos de relojoaria dentro do planetário fazem com que os planetas que seguem o sol se movam projetados no céu exatamente como eles são na realidade. É um mecanismo de relógio mesmo, 
uma coisa fantástica. (17:07), de tal maneira que vc comanda um dos astros, o sol, por exemplo, vc faz o sol andar, automaticamente os planetas vão seguindo o sol, então, eu precisava filmar os planetas girando em torno do sol, veja bem que isso hj, se fosse feito com computação gráfica, seria uma sopa no mel, uma coisa facílima de fazer.

M.L. - QUerm teve a ideia de fazer no planetário?

M.T. - Eu, rs, o que a gente fazia era o seguinte, nós estávamos trabalhando com uma câmera $35 \mathrm{~mm}$, então a gente colocava a arriflex apontada para o céu, pra abóboda celeste, só que, imagina vc, vc pode calcular como a luz fraquíssima de uma estrela ou de um planeta que incide, não grava nada, se vc fizer o filme correr, vc não grava nada, então, que qu nós tínhamos que fazer? Filmar quadro a quadro. Que que a gente fazia? Depois de fazer vários testes, o que que a gente fazia? Pegávamos o sol - até eu aprendi a manipular o planetário, eu que manipulava... o planetário tinha um sistema que projetava no céu um gráfico que correspondia à divisão de ângulos, então, eu movia o sol, de meio em meio ângulo, movia, punha em uma certa posição, depois apagava o gráfico, desligava o gráfico, que era uma projeção separada, e a câmera ficava apontada lá; que ele fazia? Mexia, movia a mão (gesto: cobre a objetiva com a mão) de um fotograma pra outro, com a câmara coberta, a objetiva coberta. Aí nós tínhamos um tempo determinado pelos testes, destampava a objetiva, deixava $30 \mathrm{seg}$ ou 45, conforme com caso, de exposição. E conseguia gravar, e expunha. (19:41)

M.L. - Essa imagem do sol estava estática? Você colocava a posição do sol, e deixava ela lá parada.

M.T. - Parado, quadro-a-quadro. Passados os $30 \mathrm{seg}$, tinha outro cara lá com o cronómetro na mão dando: "agora, tampa!" , Tampava a objetiva, ia lá no planetário, acendia o gráfico, movia com a chavinha, mais meio grau o sol, os planetas acompanhando né. O sujeito destampava a câmera, esperava 30 seg, entendeu?

M.L. - Por que não tinha um desparador?

M.T. - Porque não tinha. Rsrs, se tivesse seria uma mais sopa, mas não tinha isso. Foi feito quadro a quadro o movimento do sol e dos planetas atrás dele. Então são várias cenas que aparecem no filme. O Campo das flores é uma curiosidade minha, porque no roteiro, nós colocamos que o Guirdano Bruno Foi queimado no campo das flores. Eu não sabia como era esse campo das flores. Pus lá umas flores, com vento, barulho de vento FUUU. O barulho do vento, foi o Gaspar, não sei se vc se lembra, foi o Gaspar Soares Neto, o funcionário que depois se tornou professor na ECA, bom, isso não importa, (21:46).

Bom, eu filmei dessa forma. Pus lá as flores pra simbolizar o campo das flores, e tinha lá a estátua do Giordano Bruno que entra no meio. Um dia, eu tô em Roma, ná, num hotel numa via chamada Via de Pellegrino, que dá numa praça. Eu tô lá passeando, e de 
repente, eu tô lá com a Eda, nessa praça, eu vejo a placa, 'Campo de Fiori" , Campo das Flores. Eu tive um arrepio, a minha reação foi imediatamente virar os olhos pro centro da praça. E o que eu vi lá? A estátua do Giordano Bruno. O local onde ele foi queimado. Foi uma surpresa pra mim. Como se de repente eu caísse num abismo e pisasse no chão. Aí eu entendi porque se chama campo de fiori porque, não tem nenhuma flor ali mas tem os vendedores que se juntam. Uma curiosidade pessoal mais que outra coisa. Agora, se vc quiser, a gente pode assistir ao filme...

M.L. - Eu acho que é um filme muito experimental, tem uma linguagem muito fora do convencional, para um filme... é pra ser educativo...

\section{M.T. - é documentário}

M.L. - A ideia desse filme foi muito além do que simplesmente mostrar o movimento dos planetas, etc, a ideia era de ilustrar como a ciência evolui, era uma forma de dizer isso. Como a ciência evolui, ao contrário do processo de descascar um abacaxi, ou uma cebola, rsrs, você vai juntando coisas, vc não modifica as coisas. Na física de Newton, vc tem certas leis, a mecânica de Newton funciona de certa maneira. Quando veio a teoria da relatividade, aquelas ideias do Newton tiveram que ser revistas. Mas elas continuam valendo pra pequenos valores a velocidade da luz. (24:51).Então, não houve um jogar fora uma teoria pra substituir por outra. Ela se expandiu, aumentou, fazendo com que aquela visão antiga acabasse ficando como um caso incluído no novo caso, é um caso particular. Os conceitos da física de um modo geral estão se expandindo, e hoje estão se expandindo de uma forma assustadora, com a inclusão da mecânica quântica, com a descoberta dos quarks, tantas coisas, antigamente nem se pensava, era um absurdo pensar em universos paralelos, era coisa de ficção científica. Hoje a ciência está levando a sério essa ideia de mundos paralelos. Enfim, vc tem sempre uma ampliação progressiva da visão do mundo. O mundo vai sendo visto cada vez de uma forma mais completa.

Esse conceito foi um pouco a nossa preocupação quando fizemos o filme. Porque na época de Galileo, de Copérnico, o Copérnico, isso tá dito no filme, ele teve que lutar contra preconceitos, porque, as mudanças da ciência esse incremento científico, ele não se dá de forma pacífica. Ele se dá às vezes com embates. As pessoas que são contrárias que não querem aceitar as novas ideias, não é tranquilo. Inclusive o próprio Copérnico teve muita oposição da comunidade acadêmica e da religião principalmente, então, essa aventuda de expansão do conhecimento científico foi um pouco a nossa preocupação na realização do filme. Porque, se vc olha o céu e vê os astros se mover, movendo, a primeira ideia que surge é "tá tudo se movendo no céu, eu estou parado, eles é que estão se movendo". É muito difícil admitir o oposto, Ou admitir pelo menos uma relativização dos movimentos. Porque na verdade tudo é muito relativo nos movimentos celestes, na mecânica convencional também, por exemplo a gente tem a ideia de que a Terra gira em torno da Lua. Não é verdade. A Terra não gira em torno da Lua. A lua não gira em torno da Terra. Ambos giram em torno de um centro comun, o centro de massa. Pelo fato da 
Terra ser muito maior do que a lua, ele fica muito próximo da Tera, mas é o movimento é mais ou menos assim... (gesticula com a mão imitando Terra e Lua). Todas essas coisas fazem parte das descobertas. (28:29)

Qualquer filme que vc faça, ve tem uma possibilidade de dar certo e de dar errado. Normal. Mesmo no texto escrito. Qualquer coisa que vc faz na vida, vc pode ter um malogro, ou sucesso, são tantos fatores imponderáveis que vc não tem como prever. Nesse nosso caso, foi um caso de filme que deu certo. Eu mesmo já fiz filmes que deram errado. Que eu joguei fora. Que não cheguei a acabar. Quando dá certo, dá certo. A gente tem que assumir.

M.L. - Vcs colocam música pop no meio, Jimmi Hendrix. Tem um texto complexo e ves foram a uma gráfica de jornal... Que isso significa? Quais os significados que estão nas imagens?

M.T. - São elementos usados para identificar o espectador. Pra chamar o espectador à atenção. O Jimmi Hendrix, hj ainda ele tem um valor. Hj ele ainda tem uma expressão fantástica, mas na época era muito mais! USEI

$\mathrm{P}$ - quem decidiu colocar JH? Você gostava pessoalmente de JH?

M.T. - Eu achava, eu sempre fiz meus trabalhos em função do que eu acho interessante, mas principalmente em função do que aquilo pode ajudar na narrativa. Houve uma intenção narrativa de colocar o JH. Era justamente fazer com que as pessoas ( que gostavam do $\mathrm{JH}$ ) fossem capturadas, capturar a atenção dessas pessoas, não que fosse um modismo, mas porque era uma coisa que fazia parte da cultura da época. Era tão forte, É tão forte ... eu gosto independente disso, é tão forte que ainda tem reminiscências, as pessoas ouvem e gostam, e era uma época muito especial, né, nós fizemos aqueles filmes lá, que a gente tem dificuldade pra reproduzir, que são os filmes Colisões, Centro de Massa, tudo aquilo lá, foram feitos numa época, olha só, perto de 68, Ainda era uma época muito quente, tinha ainda muitos reflexos da revolução de 68 , a revolução cultural. (31:56). Tanto que na época, um pouco antes de fazer esse filme, nós fizemos esses filmes Colsões, etc, a partir de um seminário que foi realizado por um sujeito chamado Albert Baez (32:31) que veio dos EUA, a convite do Prof. Ernst Hamburger, que era orientador do Mikyia. (32:47).

Esse Albert Baez, por coincidência, por acaso era pai da Joan Baez. rsrs. Era físico e cineasta, e ele era nascido no México, mas era cidadão norte-americano. Era uma pessoa formidável, tanto que quando ele veio pra criar esse seminário conosco, que ele deu foi o impulso inicial pra gente fazer essa série desses 17 filmes, dos quais vc também vai se interessar, quando o Baez veio, ele trouxe na bagagem dele músicas inéditas da Joan Baez, nós ouvimos muito antes de serem lançadas no mercado. Ele trouxe e fez a gente ouvir. Uma pessoa muito simpática, morreu não faz muito tempo, acho que ele morreu há uns 5, 6 anos atrás, talvez. (33:46). Tudo isso, a produção 
cinematográfica, vc sabe muito bem, é cheio de coisas interessantes, de capítulos, de episódios. Essa coisa do Baez, que eu tô contando, é uma coisa inesquecível.

M.L.- O Baez não tem nada a ver com o Copérnico?

M.T. - Não, nada a ver. Ele foi o sujeito que deu o empurrão inicial, porque ele ficou mais ou menos um mês, uns 2, por aí, depois ele foi embora.

P - Qual foi o empurrão? Ele convenceu....

M.T. - Ele incentivou a gente a realizar esses filmes, inicialmente ele tinha vindo pra ensinar a fazer filme científico. Mas a um certo ponto, ele percebeu que não precisava ensinar ninguém. (35:24). Enfim, eu, por razões minhas, eu sabia física, porque ele era físico também, eu sabia física e sabia fazer cinema, eu fazia as duas coisas, feito ele. Ele viu que não precisava muito esforço... nós ficamos muito amigos na época.

M.L.- Ele mencionou o fato dos russos também fazerem filmes de ciências?

M.T. - Não falou nada disso.

M.L.- Vocês sabiam disso na época?

M.T. - Que os russos fizeram? Olha, o mundo inteiro fez filmes desse tipo, não só os russos.

M.L.- É que eu li um artigo que fala que quando os russos mandaram o sputnik, os americanos ficaram loucos e perguntavam "como eles ensinam lá?"( 36:20)

M - Isso eu já não sei te dizer, dos filmes feitos na Rússia na época eu não sei te dizer.

M.L.- Os russos perceberam muito cedo o potencial do cinema na educação...

M.T. - Os russos sempre foram pioneiros em muitas coisas, eu posso falar, eu não conheço cinema científico russo, não posso te dizer nada, mas se vc olha o cinema russo, vc percebe muito bem que eles são pioneiros, o próprio Eisenstein, o Pudovkin, e tantos outros conterrâneos deles, na época, né? E depois naturalmente o que nós vemos hoje no mundo infelizmente é um achatamento da arte cinematográfica, né, isso é um pouco fora do nosso tema, né, mas é importante discutir isso também. (37:26) Porque os americanos assumiram o mercado de cinema de uma forma a achatar o cinema do resto do mundo; de vez em quando ve vê um filme italiano aqui e ali, tal, mas vc não vê mais no mercado, o mercado foi absolutamtente absorvido pelos americanos, a ponto do Godard dizer, a questão de um ano atrás que o cinema morreu, o cinema está morto.

Eu já não chego a concordar tanto com ele. Eu diria que o cinema está em estado de coma. Rs. Pode despertar. É uma forma de expressão tão poderosa, o filme mesmo, o 
Copérnico mostra isso, é uma expressão tão forte, que não pode morrer. Eu posso admitir que durante um tempo, temporariamente, ele fique adormecido, mas que ele vá morrer, não, pelo amor de deus não pode. (38:43)

M.L.- Gostaria de assistir e pausar, você assistir e comentar o porquê de algumas decisões: por que botar essa imagem, quem deu essa ideia...

M.T. - Essa é uma questão muito difícil de dizer, porque a idéia, por exemplo, voltando ao Jimmi Hendrix, por que me veio na cabeça colocar o JH? Não sei explicar. Honestamente eu não sei te dizer. USEI

M.L.- Mas foi uma coisa planejada lá no começo do filme, ou se foi no meio do processo de montagem e finalização... ( 39: 53)

M.T. - Aí é uma questão minha pessoal. Eu, por exemplo, dou uma grande importância à trilha sonora dos filmes. E nunca nunca fiz filmes de grandes produções com muito dinheiro pra pagar trilha especial essas coisas. Então, o que eu sempre procurei fazer - e os filmes que eu faço são sem nenhuma intenção de ter lucro, o que eu faço, eu pego músicas... não me interessa, eu nem dou pelota pra direitos autorais, eu faço. Aí a história que cuide do resto. Então eu achava que no caso do Jimi Hendrix, se eu fosse pagar direitos autorais, mesmo na época do $\mathrm{JH}$, tá louco, né? Eu não ia ter dinheiro no bolso por 2 séculos. Era importante colocar, eu achei que era porque, aquelas razões que eu já te expliquei, tinha alguma ligação com a cultura viva da época. E por outro lado, quando vc fala mais em Copérnico, vc tem que buscar o passado. Tem que pegar aquelas obras sonoras que são maravilhosas, tem uma que eu acho uma maravilha, do Monteverdi, que pode parecer música religiosa, mas não é, é música de amor, de paixão. Uma Coisa, se vc for ler a música da canção cantada, é uma coisa belíssima. Uma força que transcende a época, né, extraordinária, tem uma força em si que transcende a época. Em qualquer época da história do mundo aquilo é bonito. Então, a música tem sempre essa função de criar o ambiente da época ou do momento, ou da situação. A gente não pode esquecer que o cinema é feito de som e de imagem. E o Som é tão importante quando a imagem, não se pode dizer que a imagem é mais importante ou a música é mais importante, os dois são importantes. (42:39)

E tem uma terceira dimensão, que não é som nem imagem, né, no meu entendimento, que é a palavra escrita ou a falada, a fala, o que conduz efetivamente o roteiro, é a fala. É o conteúdo digamos literário, que seja ou falada ou escrita, não importa, mas é uma coisa que transcende porque você pode, essa característica narrativa tanto pode ser falada como pode ser na imagem. Mas ela é uma linha que costura a imagem com o som, entendeu, o filme tem que ser uma coisa assim, cheia de ondas, que sobem e que descem, entendeu, não pode ser uma coisa "pam". A narrativa é extremamente importante. E aqui o que a gente cuidou o máximo possível foi justamente a narrativa.

Vamos ver um pouco o filme: 
Tem um detalhe interessante, o locutor, que não é o Stênio Garcia, o Fábio Perez, ele era um ... ele até ainda hoje ainda. Ele é um locutor tão fantástico, que ele pegava um texto, ele lia sem falar e dizia: "pode graavar". Ele gravava inteirinho, sem uma falha. Ele era um narrador excepcional. Bom, vamos ver. (44:33)

\section{------começa o filme}

Aqui é tudo pra criar o clima da época. Não tem nada a ver com o Copérnico ainda. $\mathrm{O}$ bispo era o tio do Copérnico. Esse texto... Eda, como é que chama o autor dos sonâmbulos, o autor do livro Os Sonâmbulos, de onde a gente tirou essas falas? (45:55)

Eda: o decreto foi d'Os Sonâmbulos, eu não lembro o nome do autor.

M.T. - O texto chama-se Sonâmbulos, de onde ..

Eda: No final também tem uma frase dele.

M.T.: deve estar citado no final, a gente depois vê. (46:01)

M.L.- nessa sequência inicial a gente nota movimento e pausa. Vocês também foram pensando nessa coisa do ritmo...

Marcelo: Aí são as técnicas de animação no table-top, né... ah o ritmo sempre, né, o ritmo é uma das questões fundamentais no cinema...tem que ter o ritmo. Isso é ... a composição fílmica é como uma composição musical. Você tem acordes, pausas, cordas, uma série de elementos que são análogos, não são iguais, mas são análogos....Por isso que o cinema tem tantas dimensões...é tão rico... você tem tantos elementos que vc tem que manipular de forma competente pra fazer um bom filme. $(47: 10)$

(há no filme uma foto por onde se anima uma sombra).

A sombra não é imagem aérea não é uma foto... foi filmada. Lá na ECA (rsrs). Foi o Chico Botelho quem filmou isso.

Malu: essa imagem, de um pátio, passa uma sombra...

M.T. é pra sugerir. Porque na época, a gente supõe, que tudo era muito formal, muito ritualizado, entendeu, então o que a gente procura aqui é reproduzir esse clima da época. Você não podia falhar, politicamente correto.... Agora vai falar das mesas. Há um certo sarcasmo nessa fala, de propósito. (48:39). Os artistas, nós, estamos lá no lixo...Isso é proposital. O Copérnico na segunda (mesa) porque ele era sobrinho do bispo. Agora entra a música solene.

Imagens de fogueira sugerindo a Giordano bruno queimado vivo. Ele já dizia de mundos habitados, nessa época. Aqui tem uma coisa que, se hoje eu estivesse fazendo o 
filme ainda, eu corrigiria. Eu acho essa sequência aqui do fogo com as flores muito longa. Devia ter a metade do tempo que tem. Isso foi filmado num campo quanquer, provavelmente na USP. São as coisas filmadas aqui - foi o CHico Botelho. É uma mistura de coisa ao vivo com table top, né...

(52:23) O Galileu era mau caráter, né. Ele era safadão. Ele quando percebeu o perigo ele se desmentiu. Perigo de ser queimado vivo também, mas as ideias dele prevaleceram de qualquer forma. --- texto do filme----- Isto é coisa mais ou menos conhecida dos biógrafos.

(53:36) As ideias de galileu não são contraditórias com as de Copérnico.

Copérnico é contrário a Ptolomeu, que falava que a Terra era o centro do Universo e o Sol e todos os astros girando ao redor. O Copérnico inverteu essa situação, ele colocou o Sol no centro do universo, ainda não se sabia de galáxia, nada disso. A ideia que eles tinham na época era que tinha estrelas o sol e os planetas, mais nada. Não tinha essa ideia de galáxia, buraco negro, nem pensar numa coisa dessas, quasares, isso aí, ninguém tinha a menor desconfiança. (54:25) O Galileu não estava preocupado tanto com a mecânica celeste, como com a mecânica do dia-a -dia, da escala humana. Então tem a experiência famosa dele, de subir na torre de Pisa e jogar as esferas, mostrar que as duas caem ao mesmo tempo... São preocupações de uma física do dia-a-dia. Por exemplo, se você está num navio. A vela, vc está andando no mar, vc está lá em cima (do mastro) e você joga uma bola, o que que acontece? As pessoas achavam que a bola e o barco iam continuar e a bola ia cair na água e não é verdade, porque no momento em que ele joga a bola, a bola já tem um movimento inercial e ela vai fazer esse movimento, vai percorrer uma parábola que vai cair em cima do navio e não na água.

$$
(55: 26) \text { até }(56: 02)
$$

Aqui ve vê, a aproximação pra boca do Copérnico, eu não tinha nenhuma imagem do Copérnico, eu precisaria ter uma imagem dele, era pra reforçar a ideia de que as palavras são dele. Esse zoom em cima da boca. Aí entra o Stêncio Garcia. Isso aqui são imagens de table-top. Tem coisa filmada no Planetário também, mas não é isso. Não, isso é ao vivo, é misturado. Porque acontece o seguinte: eu tô procurando mostrar o monstro e eu tô ligando com a ideia de uma coisa colada, toda remendada. Na época, pra explicar, porque você vai ver mais adiante na cena filmada no planetário, os planetas fazem o movimento assim (em zig-zag) Movimento de ida e volta, e pra explicar esse movimento, os matemáticos que não aceitavam de forma alguma que o sol fosse o centro, inventavam mil macetes, mil recursos matemáticos falsos pra explicar isso. No fim, ficou tão confuso e complicado, que ficou parecendo um monstro a teoria do movimento celeste. (58:02). Quando veio o Copérnico, ele simplesmente tirou a terra do centro, colocou o Sol, e tudo deu certinho, entendeu? Ele simplificou a ideia do Sistema Solar, simplificou de uma forma que ultrapassou a compreensão das pessoas. Quer ver? Tem uma experiência interessante: vc pega, desenha um triângulo com 3 pontos, e vc propõe a uma pessoa assim: com um ponto ligando aos outros pontos, faça com que apareçam 4 triângulos. As pessoas não conseguem. A solução é colocar o 
ponto acima, em uma terceira dimensão, aí vc liga com os outros pontos e vc cria 4 triângulos, mas pra vc chegar a essa conclusão, vc tem que sair pra fora, entendeu, tem que ultrapassar, extravasar a imaginação. Foi o que Copérnico fez; os outros matemáticos e astrônomos da época faziam de tudo pra explicar porque o planeta vai e volta, era uma coisa estranhíssima, eles não sabiam explicar isso aí. Inventaram tantas explicações que aí deu essa monstruosidade, que acabou sendo o conceito geral de sistema planetário heliocientrico, aí, Copérnico simplesmente tirou a Terra de volta do sol e inverteu a coisa e acabou, tudo deu certo. Uma solução. Como Colombo que colocou o ovo em pé. Deu uma pancada no ovo. (60:22)

Tassara comenta a fala de Copérnico, as cenas de table-top, as cenas do planetário. $(61: 28)$

Veja as palavras do Copérnico como são claras pra explicar isso. Claro que é muito mais fácil vc imaginar que a Terra gira e não o céu com todas aquelas estrelas, girando em torno da terra. É uma ideia muito simples a do Copérnico, E nós materializamos isso. Essa cena deixa eu te explicar como nós filmamos: Lá numa sala da ECA, nós penduramos num fio essa terra. Essa terra aqui eu preparei, comprei um globo terrestre, pintei, preparei, pra parecer a terra de verdade; penduramos, colocamos a câmera inclinada, e simplesmente deixamos a terra girar, no fio, mais nada. E o fundo, depois eu fiz uma máscara, esse é trucagem, e usei as imagens que eu tinha filmado no planetário. Entendeu?

Aí tem trucagem. Por isso que deu essa questão da cor. Mas isso depois a gente corrigiu. (62:34) Foi difícil, viu, porque quando você empurra, além do movimento de rotação, tem o movimento de balançar e tal, então, foi difícil, nem tão difícil, mas, enfim...

"A aparência da rotação diária pertence aos céus, mas a sua realidade pertence à Terra. É genial, é texto do Copérnico esse aí, o De Revolutionibus, um texto belíssimo (63:47)

Assistindo ao filme:

"Segue-se Saturno, a primeira das estrelas errantes... (64:51)"

M.T. - Isso foi feito na Higashino. Com várias impressões $(\mathrm{x})$ você podia voltar pra frente e pra trás. Primeiro eu imprimi, não me lembro, se foi primeiro o fundo das estrelas, depois com o sol, e depois uma animação, dos planetas girando em torno. Foi com fotolito. Eu fiz um mecanismo pra girar, dividido em graus, Isso deu um trabalhão. $(65: 56)$

Aí o corte do tempo, você vê que o Jimmi Hendrix começa antes de entrar o Sol. Isso é uma questão de ritmo mesmo, o ritmo exigia isso. Você cria um elemento de surpresa, e o público fica espantado, porque vc toca lá a música medieval, de repente Páumm, o Jimmi Hendrix explode... Como ele fala em sol, a luz de um belo templo, é uma frase belíssima, aquilo que Copérnico imaginava, vc vê aqui. USEI

Por um azar, a película acabou antes do fim do pôr do sol. Mas funcionou do mesmo jeito. (67:25). 
É um pulo histórico, pra vc colocar a questão, jogar a questão, lá do renascimento, da Idade Média, do passado, puxar pro futuro. Pro presente. Por isso, o Jimmi Hendrix ajudou mesmo. Tem uma função narrativa muito forte,“california...' rsrs...

M.L. - Aí, tem imagens de pôr do sol, depois tem cidade, né, paisagem urbana...

M.T. - aí tem um problema, perdeu uma palavra. Faltou: "no prefácio" essa palavra foi cortada.

M.L. - aí pula pra cidade. Eram imagens que vcs já tinham meio prontas? Por que inseriram essas imagens da cidade.

M.T. - veja, na época, é uma questão da cultura da época, moto era uma coisa, hoje serve pra motoboy só.

M.L. - aí, vcs pulam das imagens de cidade pras imagens de imprensa... tem a ver com Guttemberg, com a idade moderna....

M.T. - eu não me lembro exatamente qual era a intenção, mas a intenção era mostrar imagens do mundo moderno, e como sutilmente indicar que as ideias evoluíram através da divulgação da imprensa, tudo isso, mas era uma ideia muito solta, não tinha uma ideia muito precisa, a ideia mais precisa vem depois, que era sabe, a cultura... (vemos o filme...) (70:42). Essa foi uma questão científica que foi colocada, né, agora, aqui ele fala "quanto à questão das possíveis verdades..." porque ele vai tocar na questão da fé, da religião. Lá foi a questão científica, a ciência caminha da forma como mais ou menos eu falei, não tá muito desenvolvido, mas a ideia é essa, é que a ciência caminha, vai se construindo, como um bloco em cima do outro, vai construindo um prédio,

Volta a música, essa é a música que eu mais gosto. (71:49) Essa música é linda, Monteverdi. Aqui, a intenção era mostrar como as ideias, sem ser contra, eu não sou contra nenhuma religião, mas como mostrar que a religião pode carregar preconceitos, pode transportar, pode reforçar preconceitos, quer dizer, a ideia do passado em cima do futuro, do presente, tem essa intenção. Mostrar como o passado deveria ser melhor filtrado, pra ser adaptado às exigências do presente.

M.L. - o que eu pensava quando eu assistia isso era que os cientistas se agarram tão fortemente às suas hipóteses, quanto esses caras...

Marcello - o cientista, veja bem, o verdadeiro cientista, ele não se agarra às hipóteses: ele deve estar sempre pronto a abandonar suas ideias em função de uma ideia superior. $O$ verdadeiro cientista, né... claro que existem cientistas de categoria inferior que não pensam assim. Têm uma ideia e levam a ideia até a morte e não mudam de ideia. Mas o pensamento verdadeiro do cientista é esse: se alguém me mostra que eu tô errado, eu aceito meu erro e me corrijo. (73:30) É contrário à ideia da religião. A religião é impositiva, é dogmática. Você vê essa figura aqui esse sujeito esse sujeito que prega, 
esse pregador, ele é completamente anacrônico em relação à paisagem, a cidade está se desenvolvendo, tá progredindo, tá... as pessoas tão vivendo em volta e ele tá lá blá, blá, blá... uma coisa completamente fora da época... As pessoas eram torturadas... bastava dizer que a terra girava em torno do sol, sujeito ia queimado. Mas ele fala também: "mas não só ... a bruxa, sobre a bruxaria, que já se falava, olha esse aqui é o inquisidor...' (Copérnico comenta suas dúvidas quanto a divulgaçãoo de sua teoria).

Aí é importante, então havia a física do galileu, que era a física experimental do plano inclinado, vc joga uma bolinha, ela ricocheteia, a física mecânica, né, na época não se desconfiava da existência da eletricidade, o Newton trabalhou com luz, também, mas muito pouco, ali a física era incipiente ainda, o Glaileu, a importância do Galileu era justamente de ter criado a física experimental, né a ciência experimental, fazia a experiência no laboratório, esse é o grande virtude dele, né. O outro lá pensava nas estrelas, o Kepler. Agora, tudo isso era outra física, era outra... a astronomia era diferente da física dia-a-dia cotidiana. $\mathrm{O}$ importante foi juntar essas duas coisas com uma coisa só, Esse foi o grande salto dessa época, a grande revolução criada por Galileu, por Copérnico - não foi uma pessoa só, várias pessoas contribuíram - o grande salto da ciência foi esse, a ciência ... os astros se comportam da mesma forma como se comporta uma bolinha que eu jogo no chão. Isso é o grande salto dessa época, de evolução da ciência. (78:55)

Isso aqui é um planetariozinho pequeno portátil, nós filmamos no planetário. Esse é o planetário mesmo, eu quis fazer uma homenagem ao planetário mesmo, que me deu tanto trabalho o planetário...rsrs. (zoom na máquina do planetário)

Essas aqui são imagens de explosões solares.

M.L. - como ves conseguiram na época um rolo com essas imagens?

M.T. - Apareceu lá na ECA um dia, um sujeito que estava fazendo pós- graduação no Instituto astronômigo e geofísico da USP. E ele tinha recebido da Nasa, um rolinho de filme - esse aqui - porque ele tinha que fazer o trabalho dele de pós-graduação medindo altura, intensidade das explosões. Até não me lembro o nome dele, tá marcado o nome dele aqui nos letreiros finais. E ele sabia da existência da Higashino, que ele fez? Ele colocou o trabalho dele, foi feito na Higashino. $\mathrm{O}$ trabalho de pesquisa em astrofísica.

M.L. - Isso tem que ser citado...

M.T. - Pode colocar, o nome dele é... não me lembro mas deve estar por aí...

Então, ele media as dimensões, fez todo um cálculo da explosão do tempo de altura, do arco de fogo, ele fez esse trabalho em cima da higashino. As medidas, os tamanhos... Ele media, projetava outro, media, assim por diante. Depois nós ficamos amigos, eu sempre trabalhei com ele nisso aí. Aí eu falei: "escuta, oh, fulano, eu posso usar as suas imagens no filme que eu estou fazendo?"'Claro, claro". Essas imagens são da NASA. 
M.L. - era o copião, uma imagem positiva?

M.T. - sim, era o copião, uma imagem positiva, ele recebeu um rolinho pequeno... Isso é interessante, ne' , o encontro entre a ciência e o cinema. As galáxias não se movem assim... isso é meio fantasia... (82:39). Uma fantasia, Isso aqui é uma máscara. Pra filmar uma explos̃eo solar ve tem que tapar o sol. Mas isso é a técnica da Nasa.

Isso é um charmezinho final, cortou da mancha solar pro sol, né. Só tinha que ser assim. Parece um sábio até, muito bem escrito. Isso é obra do Chico Botelho. O Chico era um grande fotografo. Morreu prematuramente. Aqui são as músicas... (nos créditos)(84:30).

O Rudá ajudou no roteiro. O Gleice (?) era um professor de filosofia da ciência, ele era australiano, mas ele estava aqui, a gente conversou, trocou ideia. GETEF, Esse que era um grupo de estudos do qual a gente fazia parte. Que nós escrevemos textos de ensino de física, e fizemos um filme também. Fizemos um filme chamado "O Pêndulo". $(86: 27)$

M.L. - Esse é outro filme que não tem como assistir. Como faço pra assistir.

M.T. - É um filme de 5 minutos que foi feito na mesma época que colisões e centro de massa. Com sobra de material.

M.L. - e também é artístico como esse ou é mais objetivo.

Marcello - ele é objetivo, mas tem toques que eu acho interessantes. Quem montou esse filme foi o Calil. Tem uma sugestão dele muito importante: tem no filme "La chute de la Maison Usher", conhece? Nesse filme tem a cena de um pêndulo que vai e volta, você não vai se lembrar. Eu tirei essa imagem do pêndulo que vai e volta, que é o elemento de charme da coisa. O Resto foi feito em animação. Todinho. Só tem essa cena tirada do filme.

Foi sugestão do Calil. É um filme que faz uma relação entre o comprimento do pêndulo, período, uma análise matemática, simples, sobre o movimento do pêndilo, um filme rapidinho de 5 minutos. Tudo filmado em fundo preto com um os pêndulos luminosos.

M.L. - Isso ficou la na Física, era pra passar pros alunos?

Marcello - Não. Esse GETEF era um grupo dissidente do Ernst Hamburger. Eu fazia parte dos 2. Era um outro grupo, não era nem dissidente de dar tiro um no outro, né? (88:41) Mas era um outro grupo, não era nem dissidente assim abertamente, era um outro grupo de estudos que fazia textos e tal. E foi o único filme que eles fizeram. Eu fazia parte do grupo também, fizemos com sobra de material, não custou nada. Custou zero. Na época, o filme "La chute de la Maison Usher" estava na ECA, sei lá quem que 
estava projetando, cheguei lá, peguei, coloquei na higashino a cópia, e copiei a cena do pêndulo.

M.L. - vocês tinham bastante desenvoltura pra usar a Higashino, né?

Tassara - A Higashino era meu campo. Mas tem um detalhe: não foi tudo filmado na Higashino não, esse aí (refere-se ao De Revolutionibus). As fotos não foram filmadas todas lá não. Eu filmei na antiga truca, que não existe mais, que era lá que tinha uma máquina de animação, um equipamento de animação muito melhor que o da Higashino. (90:08) Com muito mais recurso, mais prático, mais fácil de lidar.

M.L. - então, pra fazer a fusão, não fazer a diminuição do obturador um por um?...

(assistindo aos créditos)

M.T. - Não, isso aí precisava, era tudo manual, mas era mais prático. Era um sistema mais acessível. A Higashino tinha muitas dificuldades, era uma máquina muito primitiva, em relação ao que tinha de melhor na época. Essa da truca era uma máquina bem melhor... $(91: 25)$

(sobre o Laboratório virtual)

M.L. - Eu tô decidindo pegar a sua trajetória como cineasta cientista. É um estudo de linguagem... por que a gente vê pontos em comum nessas produções. A gente (eu e o orientador) assistiu junto e a gente vê que tem uma colocação, uma clareza, um apontamento, que é próprio da direção.

M.T. - sim, é inevitável que você na sua carreira como escritor, pintor, escultor, ou músico, você cria, mesmo que você não queira, um tom seu. Você assiste a um filme do Fellini e reconhece imediatamente que é dele. Basta ver uma cena. O Godard, a mesma coisa, Kurosawa, o Tarkovski. Uma cena do tarkovski, porque eu conheço os filmes do Tarkovski... Uma pessoa que está acostumada a trabalhar com linguagem, seja ela qual for, e o cinema é uma linguagem, mas seja música, literatura, escultura, a pessoa acaba dadno sua impressão digital, não tem como não ser assim, só pode ser assim. E é claro que se eu tenho uma obra cinematográfica que vai desde o po;ético até o científico, passando por várias sub-etapas, e eu acho que o De revolutionibus é um pouco intermediário entre o poético e o científico, nesse sentido, então, vc tem, é impossível vc evitar que vc marque, ponha sua marca. (93:41) Normal, né. O que é mais difícil nesses filmezinhos aqui, esse é mais difícil vc dizer “ esse é filme do Marcello, ou do siclano..." , mas de qualquer forma, sempre tem a questão da enquadração, e se vc for a fundo, vc pode até acabar entendendo que seja...

Da série de filmes de física, esses são os mais simples. Esses têm uma função: o professor de física projetar pros alunos e discutir com eles. Não tem nenhuma 
explicação teórica do que está acontecendo... você mostra o fenômeno, o professor que se vire, que explique. E se o professor não souber, ele não vai saber explicar. (94:54)

M.L. - Quando vejo essas imagens, eu acho que o conteúdo científico, o fenômeno retratado traz uma beleza e um feitiço, uma seduçãoo do olhar, "o que que está acontecendo?", isso paralisa o olhar, é sobre isso que eu quero escrever, eu preciso, isso eu quero encontrar, quem é que fala disso, quem é o teórico legal pra eu estudar?

M.T. - tem uma série que eu filmei com o... eu fiz umas 3 ou 4 séries, se nõa me engano, fiz essa, não sei... fiz uma série de filmes, quem fotografou foi uma moça, a Laura, era estudante lá da ECA, veio depois de você. Ela filmava e a gente inventava essas brincadeiras aí. Ela, quando via um negócio desses, ela ficava maravilhada, sabe, encantada como fenômeno. (96:18) Agora, tinha um sujeito japonês, ele era muito bom de experiência de física, ele inventava muitas vezes. (98:05) Esse eu fiz com o Joel Yamaji, tinha esse japonês que inventava as experiências e um editor muito bom, um rapaz que conhecia música, a gente compunha música, aos poucos a gente foi descobrindo que podia fazer isso.

M.L. - Esse gráfico que tem aqui, tem lá nos filmes dos anos 70, essas pausas pra uma $\cdots$

Tasara - tem sim, um pouco o método é igual, mas olha aqui, nesse tipo de filme, uma coisa importante, talvez seja uma característica de todos eles, é que vc não tem nada em volta, vc tem só o assunto concentrado. Concentrar a atençãoo do aluno sobre o fenômeno. Tem muitos filmes educativos que têm milhões de brincadeiras, coisas de palhaço, professor vestido de não sei quê... eu acho, ruim porque desvia. Tem que isolar, chamar a atenção só pra aquilo que importa... tem uns que são muito bons, outros são menos interessantes. $\mathrm{O}$ diretor de fotografia muito bom, o produtor também muito bom. E modestamente, o diretor sabia. (100:27)

Aqui tem uma coisa curiosa, aqui tem esse radinho, tava escrito Sony... nós escrevemos SOM. Esse filme deu um trabalhao na edição, vc não faz ideia. Eu tinha que fazer de tempos em tempos uma medida. A pessoa tem que saber física, o professor tem que explicar. Se não souber física, vc pode fazer o melhor filme do mundo, não adianta.

Das duas séries feitas nos anos 2000, o Laboratório virtual é considerada por Tasara a melhor:

(102:55) Por que era mais caprichada, tinha mais recursos mais tempo, uma série de fatores.

M.L. - O Atílio pediu pra perguntar, por que a gente estuda o cinema científico hoje?

Tassara - Qual é a importância? Eu acho que qualquer estudo que a gente faça tem a sua importância, vc tem que entender, mostrar como a importância do cinema, que é essa 
linguagem extraordinária, composta de tantos fatores, tem um potencial fabuloso de comunicação, ele comunica com muito mais facilidade, (103:53) Quando nós fizemos esses filmes aí do Colisões, a Eda estava no grupo também, ela e umas outras pessoas da física fizeram umas experiências: pegaram 2 grupos de alunos e fizeram a seguinte experiência: Pra um grupo, mostraram os filmes, pro outro grupo não mostraram os filmes. Aí fizeram uma prova simulada, não tinha valor pra passar de ano, nada. Depois fizeram uma avaliaçãoo do resultado, demos nota, como se fosse uma prova de verdade. Pra um grupo que assistiu aos filmes, a média da nota foi 8 . E pro grupo que não assistiu aos filmes a média da nota foi 6 . Foi um esboço de pesquisa em que ficou claro que o filme ajudou o espectador a entender o fenômeno.

M.L. - Esse estudo tem em algum lugar? Tem como citar?

M.T. - A Eda deve saber.

Foi publicada na revista brasileira de física, de 72 ou 73: "Avaliação do filme didático de física". Acho que era 1973. Quem estava nesse grupo era o grupo que estava fazendo o trabalho dos filmes, tinha o grupo do pessoal do cinema e o grupo da física, quem fez a pesquisa era o grupo da física, era eu, tinha o nome do Ernst, que ele cobrava por o nome dele em tudo, mesmo quando não participava, o Milyia, não sei se o Mikyia. A Ruth de Oliveira césar, que era professora, a vera, a Yasuko. Na biblioteca da f;isica deve ter a coleção da revista brasileira de física. Eu não me lembro se o Mikyia estava...

M.L. - No mestrado do Mikyia, ele menciona que fizeram, pegaram um grupo enorme de estudantes...

Eda - Ela não participou quase disso, porque nós construímos todos os instrumentos de avaliação, quem orientou no design foi a professora Maria Amélia Marques (?) da psicologia, que já morreu. Isso eu me lembro bem, dos grupos que a gente fez... não acho que o Mikyia participou. O mikyia nunca fez muito o trabalho e isso aí deu muito trabalho porque tinha que construir os testes pros alunos serem submetidos, (....) e eram 3 grupos, cada grupo tinha 80 alunos, é isso que eu me lembro. E deu muito trabalho pra construir as perguntas, e depois pra analisar, não era tanto, foi feita análise estatística, mas construir os instrumentos foi difícil, porque a gente tinha que medir tudo que estava envolvido, se não me engano era a série de Centro de Massa. A primeira série. Mas já tinha bastante filme, eu acho. (109:21) A Maria Amélia era minha professora, e ela sugeriu aquele delineamento experimental, que compunha-se de 3 grupos que viam o filme, passava um tempo, depois fazia um teste, o que fazia um teste antes de ver o filme, depois viam... tinham 3 grupos, pra ver, efeitos de passagem do tempo, efeitos do próprio teste, e efeitos do filme. Então, o delineamento foi feito assim. (110:09)

M.T. - assistindo a algum filme do Laboratório virtual

Esse filme foi dificílimo, porque o fenômeno existe, mas nós tivemos que reforçar o fenômeno na ilha de edição, fazer ficar mais visível. Eu brincava coom o pessoal 
quando a gente estava fazendo esse filme, dizia que existem 3 físicas: a física experimental, a física teórica e a física cinematográfica. $\mathrm{O}$ fenômeno acontece, né. Aqui, vc vê tá girando, deu certo, mas podia não estar dando certo, então, como vc faz?, põe um imbecil lá atrás da coisa e põe uma cordinha pra fazer acontecer... você cozinha o resultado, mas o importante é o seguinte: você não está mentindo. (114:38). O importante é você usar o efeito de forma correta, honesta. Você sabe muito bem, com os efeitos especiais, vc faz o que vc quiser. Com a computaçãoo gráfica vc faz qualquer absurdo que passa na sua cabeça em imagem. Agora, quando vc faz um filme educativo, vc não pode agir dessa forma, tem que falar a verdade, não importa como, tem que falar a verdade.

M.L. - Você acha que o filme do Copérnico conversa com algum outro da sua produção? Com o Pêndulo, etc?

Tassara - eles sempre conversam entre si, né, mas o Copérnico é único nesse sentido de filosofia da ciência, porque trata mais é da filosofia da ciência. O Copérnico é mais um filme... não é de ciência propriamente, se é ciência porque está lidando com um assunto de conhecimento científico, mas vc não tem uma preocupação só de fazer a experiência é um negócio mais amplo, não... Tem um filme chamado "Laboratório sem paredes, sem fronteiras". Esse filme foi filmado em $35 \mathrm{~mm}$, foi feito inteirinho com dinheiro da FAPESP. É meu, mas nõa sei te dizer de que época. Esse é outro que deu trabalho. Ali se discute, nesse filme, como o conhecimento científico é desenvolvido em laboratório e ele vai pra sociedade, a sociedade depois devolve ao laboratório sob a forma de recurso de pesquisa, pra desenvolver novas pesquisas, entendeu? Chamava "Laboratório sem fronteiras" porque é um laboratório que existe em todo lugar. Eu gosto muito mais do Copérnico, não é um filme... mas é o único filme que tem um pouco a ver com o Copérnico. (118:12). Quem filmou isso, quem fez a fotografia foi o Fernandão lá da ECA, o Fernando Scavone. Quem montou, uma boa pergunta, não lembro. Quem montou esse filme? Não tenho cópia dele aqui. Esse foi outro que deu trabalho. Eda, vc lembra quem montou o laboratório?

EDA - um cineasta, um rapaz miudinho... eu vou lembrar o nome dele.

(tempo tentando lembrar o nome do montador - voltamos a falar sobre filmes)

M.T. - Tem o Zoom Cósmico. O Potências de 10 é mais interessante porque é mais didático, porque ele mostra que uma coisa é um décimo (sic) da outra, e explica cada vez que ele faz o zoom, ele mostra o quadradinho e faz o zoom. No Zoom Cósmico é uma coisa contínua. Vai até o espaço cósmico e volta, os dois né, vão e voltam né?

M.L. - o Potências de 10 tem o ser humano, parte do homem no meio, vai pra cima e pra baixo, ele vai a 10 a $10^{10}$ potencia e depois, 10 a -10 pra baixo. 
Depoimento de Marcello Tassara para Revista Piauí, reportagem de Norma Couri, $\mathrm{n}^{\mathrm{o}}$ 30, março 2009, quando da morte de Rudá de Andrade.

"Em meados dos anos 60, Rudá também foi responsável pela criação do Departamento de Cinema da Escola de Comunicação e Artes da Universidade de São Paulo, onde lecionou por dez anos. Foi graças a ele que a faculdade ganhou equipamentos de última linha, como filmadoras de 16 e 35 milímetros, e um Higashino, uma máquina de efeitos especiais moderníssima para os padrões da época e que só o físico Marcello Tassara, exconselheiro da Cinemateca, sabia manejar. "A reitoria só se convenceu a comprá-la quando fizemos um documentário sobre Guimarães Rosa com fotos de Maureen Bisilliat", disse Tassara, contando que o fotodocumentário levou primeiro prêmio no Festival de Brasília, e completou: "Ninguém tira de Rudá o papel de pioneiro, mas as pessoas esquecem." 
ANEXO II - Transcrição da entrevista com Maria Dora Mourão (07/11/2017)

\section{Assistindo ao filme De Revolutionibus e relatando suas impressões}

Dora - Vamos ver se eu me surpreendo com o filme que eu montei e que eu não lembro mais nada.

Dora - As trucagens todas eram feitas na Higashino, a moviola não faz trucagem. Obviamente tinha o roteiro que determinava como é que essas fotografias iam ser trabalhadas. Então, quando esse material chegava na moviola, o copião correspondente pra poder montar o resto, essas trucagens todas, em princípio, já estavam pensadas (2:10). O que também a gente fazia na moviola era .... A gente recebia o material bruto na moviola, sem trucagem, sem nada, então, ao trabalhar o material, você determinava: "aqui vai ter uma sobreimpressão, uma fusão, aqui vai ter um zoom out, um zoom-in", mas isso normalmente era visto na moviola em cima do material bruto. Esse era o procedimento normal (2:48). O que eu não lembro mais, não sei te dizer, se o Marcello trabalhou isso antes de me dar o material na moviola, ou depois. O procedimento normal era isso ser trabalhado depois. Fazia a decisão das trucagens na moviola, e daí ia pra trucagem pra elas serem realizadas. (03:07) Depois voltava pra moviola fazer o corte final. Esse era o procedimento, agora, nesse caso específico, eu já não lembro mais, se fez primeiro ou se fez depois.

Quando vai pra trucagem, você precisa saber exatamente o que quer, onde quando e a hora.

Segue a projeção do filme - até o momento da apresentação do refeitório.

Dora - Agora você vê, ele é um filme super institucional. (05:33)

Mas o que foi que surpreendeu você e o Atílio? (07:12) Até agora, é um filme super convencional, não tem nada de diferente. TRECho usado

M.L.- Vamos continuar...

Dora - Ele tem uma certa sensibilidade, Não ficou só naquelas imagens do passado, ele faz uma relação com o contexto do momento. A natureza.

M.L. - Para os dias de hj, ele é lento, assim... O próprio Tassara comentou que teria tirado fora alguns pedaços... (11:35)

Dora - Mas é que ele também tem uma proposta muito didática. Então, também por isso tem essa coisa mais lenta, a preocupação em explicar tudo...

Corte no filme para a cena do sol ao som de Jimmi Hendrix. (12:18) 
Dora - Esse sol é do Chico Botelho... ele adorava isso. Ele tem também nos filmes dele a ponte da cidade universitária... ele adorava ver esse pôr do sol. (usei)Agora, isso é uma coisa do Marcello, do diretor do filme, tentando trazer o filme pra realidade, pro contexto atual, e não pra ficar uma coisa só...de lembrança do passado, a teoria dele e tal. Então, é trazer para aqueles dias, pros dias de hoje, ele tá falando "é esse sol aqui, olha como esse sol é visto hoje pela sociedade contemporânea". Mas olha o tempo que demora pra esse sol descer. (13:44) Esse olhar lento, que tem muito a ver com a estética, que, obviamente, pra um filme como esse, científico, didático, a sensação que dá é que não combina.

M.L - Outra coisa que me intriga e que o Tassara não se lembrou, não soube responder o por quê, é o que tem a ver essa imagem de imprensa junto com essa locução. (14:18)

Dora - É o movimento, né? Ele tá falando de movimento. É isso. Tanto a descida do sol, o pôr do sol, aquela lentidão, que tem a ver com a lentidão do por do sol, quer dizer, ele não desce de uma vez, são cenas quase que realistas do tempo que o sol demora pra se por. Então, esse movimento do sol e o movimento que ele e refere, na teoria do Copérnico, a questão do movimento, e o movimento como ele é visto naquele momento. Que que é o movimento prá nós naquele momento?(15:25) é a moto passando, é o carro passando, e aquela máquina se mexendo, aquilo é movimento prá nós naquele momento. usei

M.L.- Olha só que bacana isso... também são do chico Botelho essas cenas de centro?

Dora - Ele era o fotografo, né? Nossa, eu não me lembrava dessa parte toda do filme. Olha, que lindo. ... as religiões. (16:06), pregação.

M.L. - é um documento de época, não?

Dora - total, total. Nossa eu não lembrava que essas imagens eram do De revolutionibus, olha só...E você tem uma certa crítica por trás, os teólogos cantando discursos quando na verdade, você tem uma realidade que tá ali que é muito palpável. $(17: 18)(19: 12)$

M.L - essa imagem (protuberâncias solares) foram trazidas por um doutorando da física que foi estudar nos eua e trouxe o rolo de filme da NASA.

Dora - Legal isso, né...

Malu - eu acho muito legal...

Dora - você tem razão, eu não tinha memória de mais nada, eu nem lembrava que essas imagens eram desse filme. O que tem de realmente diferente nesse filme é que ele não é um filme meramente didático, né, que vai mostrar através de fotografias como se configurou a teoria dele, etc, etc, né, ele tráz essa teoria científica para uma realidade, 
pra uma atualidade, pra um contexto atual, uma realidade - sempre entre aspas (22:17) ah, pra, um pouco trazer pro chão, né, um pé no chão na teoria científica, né, esse tipo de ciência é às vezes muito estratosférica, né. E a pessoa comum não consegue entender. Com um filme desses, ela consegue entender alguma coisa, porque ela vê, ao mesmo tempo que ela tá vendo uma explicação mais científica, ela tá trazendo isso pra sua realidade cotidiana. Algo que ela conhece... bom esse filme, gostei dele. Rrr. (22:57)

Dora - eu acho que o De revolutionibus é o único que tem desse.. . com essa estrutura de imagens atuais. ... Legal. 


\section{ANEXO III - Transcrição da entrevista com Ella Dürst (06/11/2017)}

\section{Assistindo ao filme De Revolutionibus e relatando suas memórias}

Ella - A ECA estava formando, o Tassara era notório saber, ele era físico, não sei se terminou a faculdade de física.

Esse aí é o exemplo melhor do trabalho que a gente fez ...

M.L - Eu não entendo e o Tassara também não falou o porquê dessas imagens, o pôr do sol, o som do Jimmi Hendrix...

Ella - (1:12) Isso é uma tese... o orientador dele era o Peñuela, então, todo esse roteiro foi feito em função da tese do orientador e do Marcello. Eu e o Chico, nós fomos técnicos, mas a gente filmou o que foi encomendado. O por quê, a razão, era uma coisa que, não sei, acho que o Ismail também participou disso. Mas era uma coisa Marcello e Peñuela, que era o orientador.

M.L. - É verdade que um dia desses que vocês filmaram o pôr do sol, depois viram que a câmera não estava carregada de negativo?

Ella - Eu não me lembro disso, porque teve algumas coisas aí que eu fiz sozinha e o Chico fez sozinho. E outras a gente fez junto. Então, eu não me lembro de ter participado de todas as imagens filmadas daí. Eu lembro da fogueira, do planetário, tudo isso, eu fazia as coisas mais tecnicamente enlouquecidas.

M.L. - Você estava nessa cena do jornal, da gráfica do jornal?

Ella - não.

M.L. - E você foi ao centro da cidade, filmar os hare krishnas...?

Ella - em algumas cenas, sim, mas realmente, eu não estava o tempo inteiro, eu não estava o tempo todo não, foi dividido. (3:43) Agora, toda coisa, é uma mistura do Copérnico com a semiótica.

M.L. - O Tassara nunca falou que esse filme é parte de uma tese dele, nunca falou que o Peñuela orientou, nem essa coisa da semiótica... (4:16)

Ella - AH, não, esse é todo um tratado de semiótica, junto com o Copérnico.

M.L.- Eu não conheço muito se semiótica, não era essa a minha ótica do filme. 
Ella - Eu também não entendia, na verdade isso foi feito porque o doutorado dele tinha como orientação o Peñuela. O Marcello é profundamente conhecedor de história da Arte, (5:22) profundo conhecedor de física, porque ele é físico, e juntou com um semiólogo alucinado, e deu isso. Eu e o Chico éramos técnicos da coisa. A gente não tem envolvimento nenhum com o roteiro em si. A gente tem envolvimento com a estética da coisa. Porque a gente 'tava fazendo outras coisas... A gente começou a filmar... como a gente era os mais fotógrafos da coisa, foi entre o terceiro e o quarto ano. E demorou muito tempo. Demorou muito tempo pra fazer o filme. Foi feito em etapas, então, no meio de todos trabalhos, porque a gente tinha os nossos, pessoais, Até o filme do Roberto Santos estava sendo feito junto em paralelo... junto com tudo isso, de vez em quando tinha um Copérnico que o Tassara pedia pra fazer. Porque tinha dinheiro do INC nesse filme. Então, era uma coisa que tinha prazo pra cumprir, tinha uma missão pra cumprir, mas toda preocupação não chegava até os fotógrafos. COLOQUEI

M.L. - Vocês receberam pra fazer o filme? Vocês ainda eram estudantes...

Ella - não, não. (7:16)... ele pegou algumas imagens feitas no Planetário e retrabalhou em cima, ele usou, era uma base na verdade, inclusive ele acelerou, ele mudou o próprio tempo dos movimentos que foram filmados, ele mexeu nisso na Higashino. A gente deu uma coisa bruta pra ele. As fusões foram feitas na Higashino também.

M.L. - Vocês tiveram aulas na higashino?

Ella - Tivemos, eu até fiz um projeto de filme na higashino, filme um pintor, o Henrique Alvim Corrêa, um trabalho de graduação, eu fiz na Higashino. Table-top, pinturas. Então, é uma super colcha de retalhos o filme... (9:22)

M.L. - E esse pôr-do-sol

Ella - Eu tive uma aula com ele (Rudá). Eu sou da segunda turma da ECA. Tive muito contato com o Ismail, Fui aluna da Dora, quem montou o filme?

M.L. - Dora.

Ella - Só a Dora? ... eu sou da turma de 1969. Da mesma turma do Chico. O Ismail era da turma anterior. E tivemos aula de animação com o Tassara, de montagem com a Dora, e o Leone, o Eduardo Leone... ele participou dessa montagem. Esse filme envolveu o grupo inteiro. Foi muito ... O Tassara tinha que fazer... essas coisas são filmadas. Isso aqui a gente filmou, o fogo, ... tudo ali pela USP. Tudo meio adaptado feito do jeito que dava. Ia um pouco longe, essas pedras são um pouco longe... sob a orientação do Marcello. Ele pedia mais ou menos o que ele queria... olha, eu nem lembrava disso, da existência disso aí mais. Mas isso tudo foi filmado ali por perto, ia procurar alguma parte, alguma coisa perto. E filmava pra rechear as ideias dele. Só tentava fazer o mais bonito possível. O fogo deu trabalho pra fazer bonito, mas acabou ficando. A coisa mais interessante que vai acontecer aí é o seguinte: vai ter o céu. A parte do céu ... tem fogo de monte... 
M.L. - O fogo foi filmado à noite?

Ella - Foi. Eu e o Chico éramos meio os fotógrafos, então, da turma, então por isso a fotografia acabou caindo na nossa mão. A gente já tinha lidado com câmera $35 \mathrm{~mm}$ na própria ECA. As imagens das constelações do planetário e o céu, tecnicamente tinha o problema de ter o céu, como fazer o céu e os movimentos que precisava. O Lugar possível pra fazer isso que existia era o Planetário do Ibirapuera. E sempre houve o mito de que ninguém nunca fotografou lá, que ninguém nunca tinha conseguido fotografar lá. O pessoal do próprio planetário, porque ninguém fazia certo. Ninguém tinha pensado em fazer um table-top invertido. Então, a própria ECA pediu autorização pro Planetário pra flmar lá e o Planetário respondeu: "não se filma aqui, não dá, é impossível." E nós falamos, "não, tem jeito de filmar". O Tassara o Chico, eu, a gente sabia fotografar o suficiente pra saber o jeito que dava pra fazer aquilo, que é com a câmera quadro-a- quadro, como se fosse um table-top invertido. Com exposição longa, muito longa. (USAMOS) O problema é esse: por isso que ninguém fazia, todo mundo ia lá com flash e não saía nada. Ou filmava iluminando, e não sai. Então, é um tabé-top ao contrário. Vamos calcular o tempo de exposição que precisa pra isso. Então, com a ajuda deles, eles foram sensacionais, a gente coordenou o tempo, eles deixavam a imagem projetada, parada com a câmera filmando o tempo, aí andava, exatamente como num table-top invertido.

M.L. - No espetáculo do Planetário, o céu está em movimento... eles tinham esse controle?

Ella - Tem, eles têm como parar. Foi isso que a gente foi ver lá, eu me lembro que eu fui... Teve uma vez que eu fui lá sozinha, depois na hora de filmar mesmo eu fui com o Chico, porque era horas. Horas, horas... passava o dia inteiro no Planetário com a cadeira abrindo e fechando a câmera pra fazer o quadro-a quadro.

M.L. - Demorou quantos dias pra fazer?

Ella - Eu tenho na minha cabeça que demorou assim, duas semanas (USAMOS). O Dia inteiro, parava pra comer e voltava. Ficava entendendo tudo do Planetário e acabamo ficando amigo do, do ... porque é fascinante aquele negócio, aquela máquina, é impressionante, aquilo é o máximo. É inacreditável, então foi um prazer, uma semana de table-top invertido. Porque as cadeiras do Planetário, você deita, né, você fica deitado, com a câmera no tripé... Tinha um roteirinho que o Marcello pediu, a partir do momento em que a gente falou não, vamo ver quanto tempo ... a gente chegou, era uma coisa assim de muitos minutos cada quadro. Pra imprimir. Aí fechava (o obiturador) aí o cara mexia um pouquinho, abria o obturador, mais não sei quanto tempo. Por isso que ninguém tinha conseguido fazer. $\mathrm{Na}$ verdade era um recurso elementar e simples. Alguém precisava ter tido a paciência de ir lá fazer isso. E a gente fez. E ficou bárbaro aquilo.

M.L. - E quando você chegou na Líder e viu o copião? 
Ella - A primeira vez que eu vi aquilo - hoje seria uma besteira, com o computador a gente fazia em 2 segundos - mas na época foi um luxo a filmagem, finalmente tinha o movimento que o Marcello queria. Então, o pessoal do Planetário não acreditou. ((USAMOS)Aliás, eu nem sei se eles viram e sabem ou souberam algum dia que eu certo. Porque eles botaram o projecionista do Planetário pra ficar com a gente escravizado lá mexendo na máquina devagarzinho, e ficava lá os três, um ficava um pouco, depois o outro saía um pouco, era infame. A grande novidade que teve em termos de... o filme é muito bonito, né, a novidade que teve em termos técnicos da coisa foi esse table-top invertido. (12:08)

M.L. - E lá o céu é uma abóboda...

Ella - Aí você tem a lente grande angular, aliás, eu não me lembro qual foi a lente, mas eu me lembro que teve um primeiro dia que foi de estudar que mês se encaixava naquilo, porque tem constelações que a gente filmava com plano mais fechado, então tem um planejamento de lentes, que iam ser usadas e os tempos pra conseguir aquilo, e, claro, o tempo de exposição foi um cálculo inicial que a gente supôs, eu não me lembro. O filme tem X ASA, nós vamos "puxar" pra não sei quanto, se o diafragma da lente é tal, eu acho que numa coisa preta... aí chegou lá, fizemos aquele tempo e mais, e mais, e mais, até conseguir saber qual o tempo que precisava pra imprimir as estrelas... então tava tudo planejado. Aí nós descobrimos o tamanho da encrenca, e aí fez o quadro-a-quadro. Dias, dias, na minha cabeça, uma semana.

Ella - Aquela máquina na verdade faz muito mais coisa do que tem no espetáculo, porque a maquina tem um mundo de controles. ... A gente trabalhava no escuro, pra abrir e fechar a câmera era com lanterninha. 
ANEXO IV - Transcrição Ismail Xavier (29/09/2019)

\section{Assistindo ao filme De Revolutionibus, relembrando e tecendo relações}

Lembrou-se pouco da época do filme e das decisões narrativas. Contou que foi feito pelos 500 anos de Copérnico, por iniciativa aqui na ECA por parte do Tassara, que era formado em física também.

Ismail - Foi formada uma equipe de professores e alunos, o filme é de 1973, eu estava começando a dar aula e a Ella era aluna, a Dora também já estava dando aula, a Dora foi da segunda turma formada na ECA, eu fui da primeira. E a Ella e outros alunos estavam fazendo o nosso curso naquele momento. A í foi formada equipe e teve uma equipe de roteiro, a gente leu o Copérnico, leu um pouco sobre a física da época,

M.L.- Vocês leram o livro do Copérnico, o De revolutionibus?

Ismail - Sim, sim, e lemos também um pouco, pra recaptular, os físicos da época e também um pouquinho depois, né, pra entender a polêmica em torno do heliocentrismo, a questão toda relacionada com a igreja também, né, tinha sido um problema, no caso do Galileu, que é famoso, né, e foi um pouco esse histórico que a gente procurou ter um pouquinho mais de traços, e depois teve a roteirização e a ideia de filmar no planetário.

M.L.- De quem foi essa ideia?

Ismail - Essa foi do Marcello. Foi o Tassara que conduziu toda essa parte. Eu não participei muito, eu fui uma vez ou outra, assistir lá no planetário, só pra ver como ia ser filmado. O Marcelo que conduziu, começou assim o projeto.

M.L.- É intrigante no filme, uma hora em que você sai lá da Idade Média, com aquelas músicas, coisa e tal e aí tem um corte que vai pro pôr do sol aqui na ponte Cidade Universitária, e um som do Jimmy Hendrix, quem tinha essas ideias malucas?

Ismail - Ah, eu não lembro,

M.L.- O senhor quer assistir um pouquinho?

Ismail - Eu não vou lembrar a ideia, posso ver aí o Jimmy Hendrix, você sabe a música, qual é?

M.L.- é um blues...

Ismail - Na verdade, aí tem uma questão de memória complicada, porque isso faz 46 anos, eu não tenho uma memoria em detalhes. Essas imagens são coisas do Marcello, 
porque o Marcello, além de tudo, era extremamente experiente e competente no trabalho de animação com imagens, gravuras, fotografias, tudo isso aí pra mim, é nitidamente um trabalho do Marcello, essa parte de construção iconográfica envolvendo imagens da época da arte, e os aspectos das imagens de época, que ele sabia trabalhar muito bem com a montagem, né, então tem essa primeira parte que é situar uma época, que tipo de sociedade era, que tipo de poder estava constituídos, e como uma teoria como a do Copérnico gerou um impacto muito grande. Que era alguma coisa que já estava sendo motivo de problemas para os cientistas, e ele não tinha, é uma coisa que a gente lembra bem, ele não tinha nenhuma questão se não a da ciência. Não é que ele queria contestar a igreja, não, o motivo central dele era a questão da pesquisa científica e o respeito aos resultados dessa pesquisa. Isso é fundamental. Não foi assim que ele teve um gesto político, digamos assim, pensado. As consequências políticas da teoria dele são consequências que foram muito fortes, e tal, e eu me lembro que a gente trabalhou bastante esses aspectos da, do lado digamos assim, bastante centrado na ciência do Copérnico, ele não escreveu o livro pra provocar poderes constituídos não. Estava implicado nisso uma provocação, uma contestação, de uma teoria que procurava se apoiar na teologia, aquela coisa toda, então era obviamente algo a preocupar, principalmente a igreja, mas isso foi um pouco o desdobramento da pesquisa dele, não foi que ele tinha clara a antecipação de qualquer confronto.

No caso do cinema, teve o aspecto de situar a época para além da questão da ciência, depois tem uma parte visual, que tem seu aspecto poético na questão da natureza, na tentativa de fazer algumas imagens que pudessem trazer uma experiência visual principalmente pro espectador, que criasse uma série de estímulos que fossem sugestivos, pra pensar, pra fazer conexões...

e tem um detalhe nessa história que é o seguinte, quer dizer, vou te falar aqui de conversas, que... o Tassara fez o curso de física, eu tinha formação em engenharia, sou engenheiro formado, e eu quando reencontrei colegas meus que tinham feito a poli e que tinham ido pra outros campos, foram ser professores de física, matemática, tudo isso, essas conversas todas em torno de opções que foram feitas, e como é que cada um está conduzindo seu trabalho, tudo isso, sempre tem uma tônica importante que esses colegas, matemáticos ou físicos reiteram, que é a questão do fato de que em ciência o que é fundamental é a intuição (8:45).

Sem uma intuição, sem uma direção assumida numa ideia importante, num "poder imaginar hipóteses", é uma coisa que não anda, porque o aspecto demonstrativo vem depois, tem já que ter um movimento em direção a uma hipótese que está sendo testada, vai demandar matemática, geometria analítica, vai demandar equações, tudo isso, mas essa parte de cálculo, propriamente dito, é uma etapa do processo; mas sem o movimento inicial da ideia e da convicção, e desse impulso muito forte pra poder provar, é uma coisa que não anda, é o motor. 
Pra você ter uma ideia, uma vez eu tive que, teve uma moça que fez uma tese aqui na Faculdade de Educação, faz uns anos já, e um antigo colega lá de trás, que se formou em matemática, ele pasou a ser professor da faculdade de educação, ele dá aula de didática da matemática, Nilson, o Nilson me liga e convida pra participar de uma banca, eu falei: "como, eu não estou mais na matemática", ele disse: "não, não, mas a matemática que tem aqui é a matemática que eu sei que você sabe, no caso a tese é sobre o estilo em matemática", então, você que trabalha na área de artes, e tem essa formação suficiente pra acompanhar esse trabalho, você vai gostar de ler porque é sobre a questão de estilo em matemática. Então, a tese é toda sobre esse aspecto, de como, na matemática, você tem também a possibilidade de falar em estilos. Não só a elegância, mas a hipótese, a maneira de entender como resolver um problema. Por exemplo, vou te dar 2 exemplos: um deles é o fato de que é sabido que os grandes responsáveis pelo desenvolvimento da álgebra foram os árabes. Enquanto que havia uma tradição muito forte vinda da Grécia, da geometria. Por que que os árabes desenvolveram a álgebra e não continuaram a desenvolver a geometria? Porque a questão da imagem não era uma questão que devesse ser muito tratada na cultura árabe. Então, eles desenvolveram uma abstração maior, as equações, e resolveram uma série de questões com a álgebra, né. Então, a álgebra, o nome inclusive é árabe, você sabe o que que era o algebrista? Era o cara que, uma pessoa tinha uma fratura, ele que colava os ossos, quer dizer, era equacionar os dois lados e juntar os dois lados direitinho, que é o que a gente faz na equação, né, por isso que chamaram de cálculo algébrico.

Então é um estilo de matemática que se desenvolveu a partir de uma questão cultural, como na Grécia também a geometria se desenvolveu a partir de uma questão cultural, depois essa tese conta que no século XVII, quando Descartes estava assim como um grande matemático, geometria analítica, tudo aquilo, tinha um outro matemático francês que desenvolveu um outro tipo de matemática, que foi esquecido, porque foi $o$ Descartes que se tornou mais hegemônico, e que ficou pra história que veio a diante, mas no século XIX, recuperaram algumas peças do Desarge (?) eu não me lembro, só li nessa tese, então você entende como essa questão da imaginação, da hipótese, da intuição, são questões fundamentais no desenvolvimento da ciência, junto com o cálculo matemático, junto com todas as equações, teoremas, todas as questões que são fundamentais pra provar, demonstrar, fazer o raciocínio que gera as equações, tudo isso, e no caso, você vê que provavelmente a questão do Copérnico, tinha muito a ver com isso também, né?

M.L. - O corte do qual eu falo é esse aqui, que ele corta dos planetas, com essa música da Idade Média, e tem esse corte pro sol na ponte cidade universitária, Jimmy Hendrix..

Ismail - (15:06) De repente você cai pro século XX ali e o sol. Você vê que o sol entra no lugar desse sol aqui. E em vez dos movimentos dos planetas você tem a passagem dos veículos e ...

M.L. - Ele funde a música antiga com esse blues... 
Ismail - eu não saberia dizer a razão que foi a escolha da música pelo Jimmy Hendrix...

M.L. - Uma sugestão que eu dei, que a Teresa Castro gostou, foi a comparação com 2001 Uma Odisséia no Espaço, em que ele joga o osso... e ela disse "vai, vai", porque é uma coisa parecida, você sai lá do passado...

Ismail - dá um salto do osso pra astronave... vem pros fios elétricos... contemporâneo. $\mathrm{E}$ o sol vai descendo né... E essa descida do sol é importante por causa dos movimentos relativos, quer dizer, a Terra é que está se movendo, não o sol. (16:50)

M.L. - E tem essa paciência do filme, que é essa coisa que hoje em dia os filmes não têm mais.

Ismail - É, hoje está um pouco uma montagem rápida... o digital favoreceu muito esse tipo de ... o filme não tem pressa, é pra pessoa ficar fazendo uma reflexão, pensativa diante desse pôr do sol.

M.L. - Aí ele coloca uma música pop da época que...

Ismail - QUe do ponto de vista geocêntrico é como se o sol estivesse se movimentando, e na versade é a terra.

M.L. E aí, ele vai lá pro centro da cidade

Ismail - É, eu tô revendo isso agora... é no jornal isso aí, né (imagens da gráfica). É, tem muita coisa de movimento de rotação e de translação, né... essas máquinas trabalham todas assim, né, como carros. Tem a roda, os elementos circulares fazem a rotação, o carro, a translação ... é um ponto forte... Tem o sentido desse salto da vida cotidiana, que é determinada por essa questão astronômica, da rotação da terra, tudo, e o cotidiano que todos nós vivemos diariamente essa situação, mas já ficou uma coisa que faz parte do que é uma rotina, digamos, algo ao qual não prestamos mais atenção.

M.L. - Sim, e aqui ele mostra as religiões, a figura do candomblé... da umbanda, o harekrisna.

Ismail - Tem várias questões, religião, ciência, cotidiano, escala temporal (...) arte visual representativa de determinada época, no caso, aquele século do Copérnico ...

M.L. - Hoje em dia, com essa idéia já consolidada, ninguém debate mais se a Terra é ou não o centro... então ele contrapõe com essas imagens de quando isso era uma questão de vida ou morte. Aí tem o Stênio Garcia que fala... Porque, uma coisa que eu fui atrás, nem vamos assistir tudo, se o sr quiser eu envio o link, é bonito como o Tassara... 
Ismail - Ele trabalha muito bem as imagens e...

M.L. - Na mesma época, o sr sabe o Charles e Ray Eames?

Ismail - não

M.L - Eles fizeram muitos filmes e na mesma época eles fizeram um filme sobre o Copérnico.

Ismail - Ah, é?

M.L. - Então, eu comparo um com o outro, porque tem uns elementos parecidos...

Ismail - ah, que legal.

M.L. - Mas o que eu estou defendendo é que o filme dos Eames - é muito elegante - mas é muito careta, eles vão para a Europa, eles não filmam reproduções. Aqui são todas imagens que o Tassara recolheu...

Ismail - Claro, claro, reproduções de livros...

M.L. - Os Eames foram pra todos os lugares da Europa por onde passou Copérnico. Então, tem fotos lindas, com macro, desfoque...

Ismail - AH, sim, tinha muito mais dinheiro, provavelmente $(21: 55) \ldots$

M.L - Sim, mas o resultado é uma coisa muito monótona, achei um pouco muito deslumbrada com o detalhe ... sim, é bonito, mas, e daí...? qual a relação ... Aqui (voltome pro filme) de novo, você passa do velho pro novo

Ismail - Um tipo de imagem você dá um salto, aí vem pro... aí é o planetário, né?

M.L. - É o planetário mesmo... Curioso é que ele filma a máquina do planetário como se fosse uma nave, um troço...

Ismail - Exatamente, ela ganha um estatuto que é gerador de imaginação também, né.

M.L. - Tassara falou que um sujeito que foi fazer doutorado, sei lá, nos EUA, trouxe essas imagens e ele precisava tomar essas medidas e pediu pra ele (Tassara) pra usar a Higashino pra medir. E aí, quando ele terminou de anotar as medidas, ele falou pro Tassara: "se você quiser, fica com isso". Aí, o Tassara colocou no filme.

Ismail - eu sinceramente tenho muito pouca memória do trabalho da época em que ele se desenvolveu, porque a memória, quando a gente chega aos 70 , começa a falhar... 


\section{APÊNDICES - Revistas históricas}

APÊNDICE I - Revista Ciné-club nº 4, 1948 (microfilmagem)

APÊNDICE II - Nouvel Art Cinématographique n ㅜ 1926

APÊNDICE III - Nouvel Art Cinématographique no 5, 1927

APÊNDICE IV - Cinémagasine, 1928

APÊNDICE V - Cinémagasine no 2, 1921

APÊNDICE VI - Le cinéma dans la lune

APÊNDICE VII - Le cinéma et la folie mathematique 